


Digitized by the Internet Archive in 2007 with funding from Microsoft Corporation 
PREPARED UNDER THE DIRECTION OF FREDERICK A. CLEVELAND, Ph.D. 



\title{
THE SYSTEM OF
}

\section{FINANCIAL ADMINISTRATION OF GREAT BRITAIN}

\author{
A REPORT
}

\author{
BY \\ WILLIAM F. WILLOUGHBY \\ CONSTITUTIONAL ADVISER TO THE CHINESE REPUBLIC; PROFESSOR OF JURISPRUDENCE \\ AND POLITICS, PRINCETON UNIVERSITY \\ WESTEL W. WILLOUGHBY \\ PROPESSOR OP POLITICAL SCIENCE, JOHNS hOPIINS UNIVERSITY

\section{SAMUEL McCUNE LINDSAY} \\ PROPESSOR OF SOCIAL LEGISLATION, COLUMBIA UNIVERSTTY
}

INTRODUCTION BY

A. LAWRENCE LOWELL

PRESIDENT, HARVARD UNIVERSITY

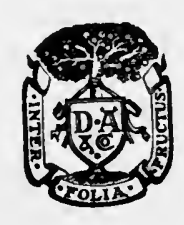

\begin{abstract}
PUBLISHED BY
D. APPLETON AND COMPANY

NEW YORK

LONDON
\end{abstract}

FOR

THE INSTITUTE FOR GOVERNMENT RESEARCH 
Copyright, 1917, by

THE_INSTITUTE FOR GOVERNMENT RESEARCH

Printed in the United States of America 


\section{EDITOR'S NOTE}

Ten years ago a definite plan was formulated for the preparation of a series of scientific handbooks through which exact information might be made available to citizens and public officers alike, about the methods and practices developed by various governmental agencies in the conduct of public business. In the spring of 1913, this plan was laid before the trustees of the Rockefeller Foundation. In response to inquiry as to what studies would be taken up first if funds were provided, the following were suggested as of commanding importance: (I) Methods of budget-making and financial control; (2) standards and practices evolved for improvement of the civil service; (3) provisions for pensions and retirement allowances; and (4) methods of public accounting.

An appropriation was made for the purpose of prosecuting these studies and placed in the hands of a special committee composed of Messrs. Jerome D. Greene, Charles D. Norton, Charles P. Neill, William F. Willoughby and Raymond B. Fosdick.

Under these auspices three men of nation-wide reputation were selected by the director in charge, each holding a chair of government in a different university and two of whom had had considerable experience in governmental administration, to make an initial visit as an unofficial commission to England, France and Germany for the purpose of collecting materials. This was to be done by establishing contact with officers of foreign Governments actively engaged on budget-making and civil service matters, and with foreign students familiar with these subjects. The method used for collecting the data was first to prepare an outline with a list of the related subjects concerning which concrete data were to be obtained; to follow this with personal interviews; to reduce the results of personal interviews to writing and submit them for correction and amendment; also to collect such documents and data on the ground as could not be readily secured in libraries or through correspondence.

The commission began its work in England early in July, I9I4. Tentative arrangements were also made to spend August and September chiefly in Paris and Berlin, with possibly some supplementary inquiries into the same subjects in Belgium, Holland and Switzerland. 


\section{EDITOR'S NOTE}

Every facility was provided for personal contact through letters from government officials and university authorities in this country, and the commission received very cordial coopperation from the American Embassy in London, through which, in addition to its recommendations from American sources, it had no difficulty in getting the attention of the responsible public officials who had to do with the subject matters of the commission's inquiry.

The commission worked as a body, although a tentative arrangement for division of labor was agreed to whereby Mr. William F. Willoughby was to give special attention to English budget materials and English documents, Mr. Westel W. Willoughby to budget and civil service practices in France and Mr. Samuel McCune Lindsay to civil service in England and to budget materials and civil service in Germany. The commission collectively, however, interviewed most of the officials and persons with whom matters were first taken up in detail in England, and the field notes of these interviews were discussed by the members of the commission as a body-the thought being that this would help to standardize individual inquiries later after the members had separated.

The outbreak of the war in the beginning of August interrupted these plans. Mr. Westel W. Willoughby had made appreciable progress in Paris, and Mr. William F. Willoughby and Mr. Samuel McCune Lindsay had gone as far as Holland when hostilities began. Under the circumstances the only thing to be done was for the members to reassemble in England, complete the collection of data which had been undertaken there relating to the English system, and then return to America.

While the war made it impossible to carry out on broad lines the original plan and rendered more or less inoperative the tentative division of labor between the members of the commission, the commission did succeed in getting full data regarding the system of financial administration of Great Britain and much valuable material relating to France, Germany, Belgium, Holland and Switzerland, which latter material may be used in future studies of continental budget procedure and of civil service and pension practice.

The results of the study of the British system of financial administration are presented in the present report. The first draft of this report was prepared by Mr. William F. Willoughby. This was completed by him during his absence in Peking as constitutional adviser to the Chinese Government, a general conference having been held with the other two members of the commission before he started, and substantial agreement having been reached as to the general charac- 
ter of the presentation, and as to the conclusions to be drawn. Later this draft was carefully gone over by both the other members of the commission, and after minor revisions was signed by all three members of the commission.

This report finds its chief value in this: That it sets forth briefly and clearly the impressions of three men, well trained and of exceptional experience, as to the scope and practical workings of the English budget system; and more especially that it sets forth those particulars which will facilitate a better understanding of the adaptations of organization and technique worked out by legislators and administrators to make effective the accepted principles of finance. It is a knowledge of the necessity of these adaptations which will be of special value in this country where the commonly accepted precepts of finance and government have been so openly and frequently violated.

When the text was completed, it was decided to offer it for publication to the Institute for Government Research, a recently organized agency for the study of national problems of which Mr. William F. Willoughby had been made executive head.

Since the commission visited England, an interesting volume has appeared covering some of the same ground, in which slightly different conclusions were reached. Reference is made to "The System of National Finance," by E. Hilton Young, M. P., 1915, Smith, Elder and Company, publishers. The point of view and popular treatment by a member of the British Parliament only gives added value to the more technical discussion of this report.

Frederick A. Ċleveland.

January, I9I7. 



\section{FOREWORD}

The Institute for Government Research was incorporated March Io, I9I6, and began active operations October I of the same year with headquarters at 8 I 8 Connecticut Avenue, Washington, D. C. To use the words of the prospectus, issued immediately upon its incorporation, it is "an institution of citizens for coöperating with public officials in the scientific study of business methods with a view to promoting efficiency in government and advancing the science of administration." The program of action which the Institute has taken to itself is that of seeking to bring into existence information and materials which will prove of value, both in forming public opinion and in assisting all officials, and particularly those of our national government, charged with the administration of government affairs in their efforts to put such administration upon a more efficient basis.

The same motive actuated the appropriation by the Rockefeller Foundation, described in the Editor's Note, of funds with which to make scientific studies in the field of administration. The results of the first of these studies are embodied in the present volume. After its completion it was offered to the Institute for publication. In view of the fact that it so thoroughly fitted in with the Institute's program of work, and also because it had been prepared by a commission, the chairman of which had been selected as director of the Institute; this offer was willingly accepted. It now appears as the first volume in the series of "Studies in Administration" which constitutes one of the series of publications through which publicity will be given to such of its work as is of a general educational character.

Frank J. Goodnow, Chairman, Institute for Government Research.

Washington, D. C.,

January, 1917. 
$\therefore \quad \therefore \quad .$. 


\section{INTRODUC'TION}

Few subjects relating to our government have attracted more attention in this country within the last few years than financial administration; few need to be more carefully overhauled; and there is no system better worth our study for this purpose than that of England. To attempt to engraft any foreign institution in a new land by direct imitation is usually disappointing, and sometimes mischievous; but to study it with a view to getting suggestions for improvement of one's own methods is wholly wise. We have every reason to be grateful, therefore, to the authors of this small book for their description of the British Financial Administration in terms so clear as to be easily understood by anyone without technical knowledge, and with a singularly well chosen proportion between the different parts of the subject.

After discussing the general principles that must underlie sound public finance everywhere, the writers follow the course of financial action in England from the preparation of the estimates in the different departments, through their consolidation into the measure presented to Parliament, the procedure of the House of Commons thereon, the subsequent orders drawn on the Bank of England, the expenditure of the money, and the accounting therefor, showing the significance of each step in the process and its bearing upon what goes before and what follows.

The casual reader may be surprised at the small amount of space devoted to the discussion of the appropriations.in Parliament, but this is right, because, in fact, those debates relate to the political and not the financial aspects of the matter. One can say of the relation of the House of Commons to the financial administration what Bagehot said about the relation of good ministers to departments, that it is not their business to manage the finances, but to see that they are properly managed. The unity of the financial management, that which makes it rational, depends upon the fact that the authority and responsibility for appropriation and expenditure is lodged in one hand, that of the ministry in power. For we must remember that, although the imposition of taxes and the raising of revenue thereby is a legislative matter, the expenditure of the money 


\section{INTRODUCTION}

is essentially an executive or administrative function, which ought to be carried on under the careful supervision, but not under the immediate direction, of the legislature. After the law-making power has determined the objects for which money is to be spent, it is for the executive to attain those objects with the greatest economy and effectiveness, and this cannot be done unless the executive has a free hand, unfettered by directions imposed for local, personal or political motives.

But the executive cannot conduct the public finances properly unless it has developed within itself an appropriate machinery as a safeguard against extravagance or wastefulness. With this machinery, and particularly the functions of the Treasury in framing the estimates and controlling the expenditure, the book is chiefly concerned. It can be recommended earnestly to all those who want to understand the defects of our own financial organization, and some of the methods by which that organization may be improved.

Cambridge, Massachusetts,

A. Lawrence Lowell.

December 20, I9I6. 


\section{CONTENTS}

CHAPTER

PAGE

I. Analysis of the Problem of Financial Administration OF A GovernMENT . . . . . . . . . I I

Analysis of the Problem; Nature of a Budget; Recommendations of President Taft's Commission; The Problem of Control.

II. Some Fundamental Features of the English System of

Financial Administration . . . . . .

Fiscal Year; Theory of Public Accounts; Expenditures Made Only in Pursuance of Appropriation by Parliament; Historical Development of the Present Appropriation System; Separation of the Personal Revenues and Expenditures of the Sovereign and Those of the State; The Civil List; The Consolidated Fund; The Exchequer; The Collection and Expenditure of Funds Authorized by Parliament Only Upon the Request or Approval of the Crown; Distinction Between Permanent and Annual Appropriations; Consolidated Fund Services; Supply Services.

III. The Estimates: Preparation and Submission .

Appropriations Made Only in Pursuance of Formal Estimates; Estimates the Act of the Ministry as a Whole; The Treasury the Authority for the Preparation and Submission of the Estimates; Special Procedure for the Army and Navy Estimates; Treasury Estimates Circular; Estimates as Submitted by the Several Departments to the Treasury in Large Part but a Summation of Provisions Already Approved by the Treasury; Comparative and Explanatory Data Required; Estimates to be Justified Though No Increase Is Requested; Preparation of Estimates Within the Departments; Examination of the Estimates by the Treasury; Transmission of the Estimates to the House of Commons; Supplementary Estimates. 
IV. The Estimates: Character and Form . . . .

Classification of Estimates; Appropriation Heads; "Votes"; Appropriation Subheads; Supporting Details; Order of Presentation of Data; General Summaries and Analyses.

V. The Estimates: Appropriations in Aid . . . .

Theory of Appropriations in Aid; Statement of Arguments in Favor of the System; Criticism of the System; Contrast with American System of Reimbursable Appropriations.

\section{The Estimates: Action Upon in Parliament}

Financial Powers of Parliament Now Vested Wholly in the House of Commons; Rules of Procedure Governing the Consideration of Estimates in the House of Commons; Distinction Between the Authorization of Expenditures and the Appropriation of Funds; Votes on Account; Excess Votes; Votes of Credit; Appropriation Acts; Extent of Control Over Appropriations Actually Exercised by the House of Commons; Establishment in 1912 of the Select Committee on Estimates.

\section{ViI. Disbursement of Public Funds}

Control of Exchequer Issues by the Comptroller and Auditor General; Grants of "Credits" to the Treasury; Issues of Money from the Exchequer to "Principal Accountants"; The Paymaster General; Departmental "Accounting Officers"; Personal Liability of Accounting Officers; Accounting Officers Not Bonded.

\section{ViII. Treasury Control Over Expenditures}

Expenditure of Appropriations Not Mandatory; The Treasury the Authority for the Authorization of Expenditures; Treasury Control Over Organization and Personnel; Treasury Control Over Expenditures for Quarters, Equipment, Supplies, etc.; Organization of the Treasury for the Exercise of Its Powers of Control; Treasury Use of Departmental and Interdepartmental Committees of Investigation; The Treasury as a General Organ of Administrative Control. 
IX. Office of Works and Public Buildings : • . 183

Distinction Between Public Works Proper and Government Works; Government Works; Military and Naval Establishments; Government Works; Civil Services; Office of Works and Public Buildings; The Estimating and Voting of Funds for Public Buildings; Commitments; Distinction Between Cost of Construction, Maintenance and Repairs, Operation, etc.; Office of Works and Public Buildings Submits Estimates for All Public Works Proper; Transfer of Funds from One Item to Another in the Works Program; Construction of Public Buildings; Renting of Buildings; Maintenance and Repair of Buildings; Supply Work of the Office of Works and Public Buildings; Powers of Office of Works and Public Buildings to Control Expenditures.

\section{Stationery Office}

The Estimating and Voting of Funds for Stationery and Printing; Allotment of Appropriations; Procedure in Purchase, Warehousing, and Issue of Supplies; Powers of Stationery Office to Control Expenditures.

XI. The Audit of Public Accounts

History of Development of the Present Audit System; Status of the Comptroller and Auditor General; The Method of Keeping and Rendering of Accounts Prescribed by the Treasury; Audit of Public Accounts; Powers of Comptroller and Auditor General in Respect to Disallowance of Items; Duty of Comptroller and Auditor General in Respect to the Control of Unwise or Extravagant Expenditures; Standing Committee of Public Accounts of the House of Commons.

XII. The System of Financial Reports

Finance Accounts; Appropriation Accounts; The Estimates; Lack of Any General Report of Audited Receipts and Expenditures.

\section{The Budget}

Financial Statement, 1914-1915, Showing Revenues and Expenditures as Laid Before the House of Commons by the 


\section{CONTENTS}

CHAPTER

Chancellor of the Exchequer when Opening His Budget, May 4, 1914; Financial Statement, 1914-1915, Explaining the Proposals Made by the Chancellor of the Exchequer in His Financial Statement on Monday, May 4, I914; Budget Speech of the Chancellor of the Exchequer; Lack of Any General, Comprehensive Budgetary Statement.

XIV. Conclusion $\quad$ •

Appendix I. Exchequer and Audit Departments Act, i866, and Treasury Minute Thereon ' 283

Appendix II. Consolidated Fund (No. I) Bill, 19I2 . . 314

Appendix III. Consolidated Fund (Appropriation) Act, I9I2 . . . . . . . . . 316

Appendix IV. Forms Authorizing and Granting Credits AND Exchequer Issues . . : $\quad 348$

INDEX $\quad$ • $\quad \cdot \quad \cdot \quad \cdot \quad \cdot \quad \cdot \quad \cdot \quad \cdot \quad \cdot \quad \cdot \quad \cdot 357$ 


\section{THE SYSTEM OF FINANCIAL ADMINISTRATION OF GREAT BRITAIN}





\title{
THE SYSTEM OF FINANCIAL ADMIN- ISTRATION OF GREAT BRITAIN
}

\author{
CHAPTER I \\ ANALYSIS OF THE PROBLEM OF FINANCIAL \\ ADMINISTRATION OF A GOVERNMENT
}

Analysis of the Problem; Nature of a Budget; Recommendations of President Taft's Commission; The Problem of Control.

In entering upon an examination of the methods employed in meeting a problem of any complexity it is essential to have, at the beginning, a clear understanding of the character and terms of the problem itself. Only as one has such an understanding is it possible for him to appreciate the significance of the facts coming to his attention, to determine whether particular practices are or are not of a character to commend themselves - in a word, to comprehend and pass judgment upon the features of the system under examination. It is to be regretted that, so far as this commission is aware, no such statement or analysis of the problem under consideration is available. ${ }^{1}$ This commission has, therefore, thought it desirable, before proceeding, to its report proper, to attempt at least to outline its undertaking. By so doing it is thought that the reader will be better able to follow the description

1 The consideration of the problem of the administration of the public finances given by Professor $H$. C. Adams in his "Science of Finance: An Investigation of Public Expenditures and Public Revenues" (Henry Holt \& Co., New York, 1909), is in many respects excellent. His analysis of the problem does not, however, precisely meet the needs of the present report. 


\section{BRITISH FINANCIAL ADMINISTRATION}

Unity

of the

Problem to be Considered

Elements

that is given in the pages that follow of the particular means employed by Great Britain in administering its finances.

The desirability of making such an analysis is especially great because of the fact, upon which great emphasis is placed throughout this report, that there is an essential unity to be observed in the problem of administering the finances of a government. Though financial administration is an undertaking capable of division into a number of clearly distinguishable operations, such as the preparation of estimates, the appropriation of funds, accounting, reporting, auditing, etc., all of these operations constitute but parts of one system, which are, or should be, so integrated and adjusted as mutually to support each other and together make up one harmonious whole. Indeed, it may be said that the merits of a particular system are almost wholly dependent upon the extent and accuracy with which this adjustment is effected. It is in the skill with which this requirement has been met that one finds the chief merit of the British system, and in its disregard lies the chief defect of the American system.

Analysis of the Problem. The operations involved in the securing and spending by a nation of necessary funds, whether derived from revenue or loans, embrace the following distinct, but intimately related steps:

From the Revenue Side:

I. The determination by the law-enacting authority (the legislature) of the sources from which and the conditions under which the government revenues shall be obtained and loans made.

2. The organization and operation by the executive, in accordance with instructions, in part given by the legislature and in part emanating from itself, of a machinery and procedure for the collection of this revenue and for the sale of credit obligations.

3. The keeping of accurate records and books of ac- 


\section{ANALYSIS OF THE PROBLEM}

- count showing the revenues accruing, the credits sold, the amounts actually collected, and the balances uncollected.

4. The audit of these accounts, by an officer independent of the executive, for the purpose of ensuring:

(a) That all revenues accruing and all credit sales are in fact collected or that adequate reason exists for their non-collection, and

(b) That all sums collected are duly accounted for.

5. The rendering of reports summarizing the data produced through these operations and making known the results obtained from the revenue and loan system that has been established.

From the Custody Side:

I. The organization and maintenance of a treasury system for the receipt, custody and issue to paying officers of the revenues and loans so collected.

From the Expenditure Side:

I. The preparation by the executive of estimates setting forth the sums which, in its opinion, will be required for the due conduct of public affairs during the period to which such estimates relate.

2. The preparation by the executive of a corresponding estimate of the probable income from revenue and loans that will accrue to and be received by the government as the result of the operation of existing provisions of law regarding public dues and credit operations during the same period.

3. The preparation by the executive of a statement showing the condition of the public treasury ; that is, a document in the nature of a balance sheet showing the available assets and liabilities of the government at the beginning of the period covered by the two foregoing estimates or at the date as of which the statement is prepared and the estimated condition as of the end of the period to be financed. 
4. The submission of these three documents to the revenue-determining and fund-granting authority (the legislature) in such a form that the relationship between the actual and estimated receipts, disbursements and financial condition may be clearly seen, and especially whether, in case the estimated revenues and borrowings on the one hand and the estimated expenditures on the other are approved, a deficit or surplus will result, and the manner in which, in the opinion of the executive, this deficit should be met or surplus utilized.

5. The consideration of these estimates, financial statements, and recommendations by the legislature and, on the basis of such consideration, the determination by that body of :

(a) What modifications, if any, should be made in the revenue and borrowing system as it exists; and

(b) The sums that should be appropriated to meet expenditures authorized.

6. The organization and operation by the executive, in accordance with instructions, in part given by the legislature and in part emanating from itself, of an administrative machinery and the adoption of rules of procedure to govern the expenditure of the sums so placed at its disposition, which machinery and procedure shall provide for:

(a) The steps to be taken in directing or authorizing the expenditure of money, that is, in incurring liabilities;

(b) The examination and adjudication of all claims against the government and certification for payment of those found to be valid;

(c) The organization and operation of a system through which the sums so found to be due will be actually disbursed; and 
(d) The requirement and use of a system of requisitions, orders, vouchers and other documents that will constitute the original warrant for, and evidence of, all these expenditure operations.

7. The keeping of books of account in which all these transactions, as evidenced by these documents, will be recorded, with a proper segregation of items to the end that not only may a due accounting be had of all expenditures authorized or actually made, but also that at all times information will be promptly available regarding the purposes for which expenditures are authorized or made.

8. The organization of a system of financial reports to the end that at regular intervals complete information regarding current assets and liabilities, receipts and expenditures, may be furnished to administrative offcers, to the legislature, and to the general public, so that they or any of the several parties in interest may properly perform their duties in determining what engagements shall be entered into, and in controlling expenditures authorized.

9. The audit of these asset, liability and expenditure accounts, by an officer independent of the executive, for the purpose of verifying their accuracy and ensuring that all legal requirements and conditions, as imposed by the fund-granting authority, have been complied with.

Io. The rendering by such audit officer of a report to the legislature setting forth the results of his examination of the accounts, and, as an essential feature of such report, giving to that body complete and detailed information regarding the manner in which the funds granted by it have been expended.

The Nature of a Budget. In the foregoing analysis we have sought to do two things: To distinguish carefully be-

Unity of the Probthe
lem 


\section{BRITISH FINANCIAL ADMINISTRATION}

tween the several factors involved in the problem of managing the finances of a government; and to indicate the close relationship that exists between these several elements. A statement such as this shows in a concrete way the interdependence of the several processes upon which we have already laid so much stress. It will be seen that, on the expenditure side at least, the operations constitute links in an unbroken chain, starting with the estimates and leading through the successive links of: Consideration of these estimates, the granting of funds based upon such consideration, the expenditure of the funds so granted, the keeping of proper books recording these expenditure operations, the rendering of proper accounts, the audit of these accounts, and the making of reports giving the results of these transactions, which last furnishes the basis for a new estimate as the starting point for another chain of operations.

A moment's consideration will show that, though this is the sequence of operations under almost any system, if these

A Plan of Financing operations are to dovetail into each other in such a way that the records of one support the others, all must be planned and carried out with this end in view. Only as this is done can a country be said to have an effective scheme of financial administration. This means that each process must be treated as a link in an unbroken chain and there must be an underlying system which has a uniform nomenclature, segregation of items and classification of data devised to attain the end sought. Unless this is done the result will be a mass of data that cannot be easily understood or brought into comparison, and effective legislative and electoral control becomes impossible.

Not only should these several operations be conducted on such a basis and the facts presented in such a form as to be

Should be Easily Understood easily understood, but adequate steps should be taken by means of which comparisons and adjustments may actually be made. Though each financial year constitutes a distinct period, no one year should be completely isolated and con- 
sidered apart. If estimates of future needs are to be anything more than mere guesses they must be based upon the determined experience of past years. Not only should the executive, which is charged with the preparation of the estimates, be guided by such experience, but it should submit its estimates to the legislature in such a form that that body can see at a glance the extent, and the features in respect to which, these estimates depart from previous authorizations and actual Estimates Should be Based on expenditures in accordance with such authorizations.

Furthermore, this statement of estimates of future needs in comparison with prior authorizations and expenditures should also be brought into contrast with the resources of the treasury, whether consisting of balances on hand or income to accrue, from which these proposed expenditures will have to be met. Finally, it is imperative that this statement of prior experience and of estimated future needs should cover the entire financial operations of the government in one consolidated presentation. Unless the legislature is given information regarding the total of past expenditures, and of liabilities that it is asked to authorize for the future, and the total of the resources that will be available from which to meet such liabilities, it will have to work in the dark, not knowing whether its action will result in a treasury deficit or surplus. Only as the legislature thus has laid before it all of this information so arranged, with the items properly segregated, totaled, compared and proved as to their accuracy, is it possible for it intelligently to perform its function of determining what receipts and expenditures shall be authorized for the coming year.

The document through which all this information is brought together in one consolidated, coördinated and comparative statement is technically known as "The Budget." "The Budget" thus is not so much one of the distinct financial operations of the government as the means through which the sevBudget Defined eral operations, actual and prospective, are brought together and clearly presented, to the end that they may all be con-

Appropriations Should be Within Resources 
sidered at one time in their relations to each other. A budget is a definite plan or proposal for financing the business of a future period both with respect to revenues and expenditures. It is usually prepared and submitted by the executive to the legislative branch of the government for its approval, together with such collateral and supporting information as is needed to sustain the conclusions reached. Through a budget the experience of the past is made available to the legislature and to the people as a basis for consideration and arriving at determinations for the future.

It is of the utmost importance that this fundamental character and purpose of the Budget should be clearly apprehended. It is the one thing which binds detached operations into a logical and harmonious system and permits consideration of the activities and the cost of the government as a whole. Without it a country can scarcely be said to have a financial system, certainly not a scientific system.

Recommendations of President Taft's Commission. The best statement as to the character of data that should be included in a comprehensive budgetary statement is that contained in the summary of recommendations of the President's Commission on Economy and Efficiency in its report to the President on "The Need for a National Budget." 1 The more important parts of these recommendations read:

"The commission recommends :

I. That the President, as the constitutional head of the executive branch of the Government, shall each year submit to the Congress, not later than the first Monday after the beginning of the regular session, a budget.

2. That the budget so submitted shall contain:

(a) A budgetary message, setting forth in brief the

${ }^{1} \mathrm{H}$. R. Document No. 854, 62d Congress, 2d Session; see also Senate Document III3, 62d Congress, 3d Session, "A Budget." 
significance of the proposals to which attention is invited.

(b) A summary financial statement, setting forth in very summary form: (I) The financial condition; (2) a statement of the condition of appropriations and other data pertaining to the 'general fund' as well as to the other funds of the Government; (3) an account of revenues and expenditures for the last completed fiscal year; and (4) a statement showing the effect of past financial policy as well as of budget proposals on the general-fund surplus.

(c) A summary of expenditures, classified by objects, setting forth the contracting and purchasing relations of the Government.

(d) Summaries of estimates, setting forth:

(I) The estimated revenues compared with actual revenues for a period of years.

(2) Estimated expenditures compared with actual expenditures for a period of years.

(e) A summary of changes in law, setting forth what legislation it is thought should be enacted in order to enable the administration to transact public business with greater economy and efficiency, $i$. e., changes in organic law which, if enacted, would affect appropriations as well as the character of work to be done.

3. That the Secretary of the Treasury be required to submit to the Congress the following detailed reports supporting the general summaries and Executive conclusions or recommendations contained in the budget, as follows:-

(a) A book of estimates, containing the supporting details to the summaries of estimates of expenditures contained in the budget. 
(b) A consolidated financial report, containing a detailed statement of revenues and a consolidated statement of expenditures by departments and establishments for the last five fiscal years, with such explanatory matter as is necessary to give information with respect to increases or decreases in revenue or expenditure or other relations to which it is thought that the attention of the executive and legislative branches is to be given.

4. That the head of each department and independent establishment should be required to submit to the Secretary of the Treasury and to the Congress annual reports which, among other things, would contain detailed accounts of expenditures so classified as to show amounts expended by appropriations, as well as by classes of work, together with the amounts of increase or decrease in stores, equipment, property, etc., including lands, buildings and other improvements, as well as such other data or operative statistics and comment in relation thereto as may be necessary to show results obtained and the economy and efficiency of doing government work as well as of contracting and purchasing."

Principles of Responsibility and Accountability

The Problem of Control. In the foregoing outline we have dealt with what may be called the mechanics of the problem. If this machinery, however, is to work smoothly, and give good results, a vital principle must find expression throughout the entire chain of operations. This is the principle of responsibility, accountability and control. It goes without saying that the great end to be sought in the administration of the finances of a nation is the ensuring that the maximum of economy and efficiency will obtain in the determination of what the government shall do and in the execution of the work determined upon. A study of the problem of financial 
administration in its practical aspects shows that opportunities for misapplication of funds, waste, and, in many cases, actual fraud, exist at almost every step. In estimating and in appropriating for future needs, expenditures may be included for purposes having little or no real utility, or at least for purposes where the utility is relatively little in comparison with other needs for which no, or inadequate, provision is made. A glaring example of waste in this way is the admittedly gross misapplication of funds in the United States for public works, public buildings, and Army, Navy, and other posts, for which no real public need exists.

Again, in the expenditure of the funds appropriated, loss may occur at every point. Receivers of public moneys, custodians of public funds, and those having money placed in Principles of Fidelity and Effciency their hands with which to make payment of claims may through fraud or carelessness fail to account for all money coming into their possession. Executive officials intrusted with the discretion of authorizing the incurring of obligations, though guilty of no fraud, may exercise this discretion in a careless or inefficient manner; excessive salaries may be paid; the purchase of materials not needed or of a quality more expensive than conditions call for may be authorized; materials and supplies in themselves proper may be used in a wasteful manner; a large number of employees may be employed to do work which a smaller number, properly directed and supervised, could readily perform; public property may be converted to private use; and in scores of ways the government may fail to receive a due return for its financial sacrifices.

It is important to note that these opportunities for loss do not arise solely from the fact that in all large bodies of men The Need for Perspecthere are sure to be persons who are dishonest or inefficient. The greatest difficulty that has to be met arises from the fact that often the interest of the individual parts of the government are, or seem to be, in opposition to the interest of the government as a whole. The officials in charge of 


\section{BRITISH FINANCIAL ADMINISTRATION}

each branch of the government service and, in large part, of each subdivision of a branch, are concerned with the interests of that branch or subdivision and feel a responsibility only to a limited extent for the government as a whole, or for the service of which they are a part. Even if they have such an appreciation it is but natural that they should feel that the importance of their work is greater or more urgent than that of many other government operations. It is inevitable that their attitude should be that of seeking to secure for the work intrusted to them the largest appropriation of funds that it is possible to obtain. They feel that there is a lump sum available for the support of the government, that all this money will be spent in some way, that if they do not get it some other service will, and that no real economy will result by their moderating their demands. From the expenditure side they are not only interested in having their employees highly paid, in having the use of comfortable quarters, and in making use of high class materials and supplies, but they have the feeling that any savings resulting from their denying themselves in these respects will but mean that larger opportunities for extravagance will be opened up to the other services. It must be recognized that the actual expenditure of moneys takes place in these subordinate, or working, units, and it is precisely in these units that the interest in the public treasury as a whole is the weakest.

Central

Control

Essential to Wise

Expenditure

These are the fundamental conditions that have to be faced if real economy and efficiency are to be secured in the administration of the public finances. There is but one way through which these difficulties can be overcome, namely, through providing means by which a rigid supervision, control, and accounting may be exercised at every step from the first estimating of the needs of the several services to the final expenditure of the sums voted. It is impossible to overestimate the importance of this consideration. The most perfect system for performing the mechanical operations involved in administering the finances of a government will utterly fail to secure 


\section{ANALYSIS OF THE PROBLEM}

economy and efficiency unless this exceedingly difficult problem of supervision and control is properly met.

This supervision and control must, moreover, be a real and not merely a nominal one as is so often the case. It must be exercised by an officer who himself has the knowledge permitting him to perform this function intelligently, and is himself subject to supervision and control in respect to the manner in which he performs his duty.

The importance of this principle and some of the difficulties presented in putting it into practice may be seen by running through, from this point of view, the several operations involved in the management of the finances of a government

Control Must Be Real

The Preparation of Estimates a First Step in Control as enumerated above. The starting point in these operations, as has been pointed out, is the preparation of the estimates. In performing this operation the first step is the submission, by each working unit of the government to the head of the service of which it is a part, of a statement of the funds that it will require in order to perform the work that it purposes to put through. These units, as already indicated, are not interested, except in the most incidental and indirect way, in the general financial problem of the service as a whole or of the government as a whole. Their interest is in their own work, and their natural and legitimate desire is to secure funds for its extension. There is thus presented at the very outset a necessity for supervision and revision of these estimates as first submitted. If this is not done it is certain that the total of the estimates as finally aggregated will far exceed the amount with which it is advisable to charge the Treasury. The first point at which control should be exercised is therefore found on the desks of the heads of the several branches of the public service. Upon them should fall the duty of rigidly scrutinizing all requests for funds submitted to them by their subordinates, of comparing them with current appropriations and past expenditures, and of taking such action as will ensure that no funds are asked for beyond those necessary for the economical administration of the affairs of their 


\section{BRITISH FINANCIAL ADMINISTRATION}

Review by Department Head

Central Executive Review and Revision

Legislative Review and Approval or Disapproval services, and stuch expansion in the scope of their work as general financial and other conditions warrant. Control at this point is vital since the heads of the several services alone are in possession of that personal and direct knowledge of conditions and needs which will enable control to be exercised in the most efficient manner.

The second point at which an opportunity for control appears is where the estimates, as revised by the heads of the several services, are submitted to the heads of the great departments or other main branches of the government service of which they are the primary subdivisions. Here the control must be of a more general character. In many cases it will rest upon considerations of general policy rather than upon the question of whether the sums asked for to perform a given amount of work are or are not excessive. Nevertheless, if proper financial and work records are maintained, there exists at this point opportunity for a real scrutiny of financial needs in relation to work to be done.

The third opportunity for control presents itself when the requests for funds are aggregated into a consolidated estimate of expenditures for submission to the fund-granting authority. This work of aggregation and submission is, in most systems, performed by the chief financial officer of the government. A question of great importance thus arises at this point, as to whether the duties of this officer in respect to estimates are purely ministerial or whether they include the authority to suggest, and if need be to enforce, the modification of the estimates as reviewed by him with a view to the reduction in the sums asked for, or their modification so as to make them conform more nearly to his views in respect to the financial needs of the services involved.

The next stage in the history of the budget is its examination by the legislature. It is hardly necessary to point out that opportunity is here afforded for the exercise of a most effective control on the part of the fund-granting over the fund-expending authorities. The extent to which this oppor- 
tunity is availed of, and the means or procedure employed in exercising this opportunity for control, constitute one of the most significant and important features of the financial system of a country.

There is still one other authority by whom at least a certain moral control may be exercised. Reference is had to the general public. Provision can be and, in certain cases, is made for the publication of the estimates as tentatively prepared for submission to the legislature, and the granting to interested parties of an opportunity to urge upon the government such changes as the increase or decrease of funds for particular purposes. This practice, it should be observed, is one which is more applicable, and more usually employed in respect to, municipal or local budgets than those for national governments.

The fundamental feature which distinguishes democratic from autocratic government is this: That in a democracy the government in last analysis is controlled by the will of the people-the wishes of a majority of the governed; whereas in an autocracy the government in last analysis is controlled by the will of a ruler who is accepted as sovereign and who considers that the people are his subjects. The one bases its institutions on voluntary coöperation, taking the will of a majority as the will of all; the other bases its institutions on servitude. Democratic and autocratic, however, are relative terms. Autocracies are never absolute, and democracies have difficulty in finding the means of determining, expressing, and making effective the will of a majority. One of the means of doing this is through a representative body called a parliament or legislature - a meeting of chosen representatives of the people to parley, to consider, to act on propositions which are brought before them. But representatives must be chosen, and even they may misrepresent what the people want. A second and still more popular agency therefor, called the "electorate," has been created, which sits in judgment on definitely formulated propositions and issues which may be 
The Representative Body as a Forum
The Definition of Issues

brought before it. It is in their importance to this ultimate authority-the electorate-that budget procedures, in the course of their development, find their greatest constitutional significance. $^{1}$

The constitutional significance of an effective budget procedure is that it provides a means for making both the executive and the legislative bodies responsive and responsible to the will of the people. This is done not alone by making the estimates public property by having them printed. Such publicity is of small importance; they have to do with highly complex and technical subjects; and even if they were perfectly understood by each of ten, fifty, or one hundred million people it would be necessary to provide some practical way for having issues formulated, discussed and decided. An effective budget procedure utilizes the machinery of government for doing all these things. Responsibility is definitely located with the executive for the preparation, submission, explanation and defense of reports on the doings of the past and of plans for the future. Definite responsibility is placed in the legislature (as the representatives of the people who have no responsibility for administration) for independent review, criticism, approval or disapproval. Since every public undertaking is necessarily based on some concept or theory of welfare, and with respect to these different men may hold different opinions, procedures have been devised which provide for first getting before all the representatives of the people a full statement of facts, and then for giving to those who oppose and those who favor the proposals before them an opportunity to formulate and discuss the issues raised. During the last century a legislative procedure has been developed which is adapted to doing three things: (I) To define clearly the issues raised both on questions of general policy and on details of proposals; (2) having done this,

${ }^{1}$ See discussion of Constitutional and Administrative Purpose of a Budget in Municipal Research, Nos. 57, 58, 61, 62, 69, 70, 72 and 73 , published by the Bureau of Municipal Research, New York, I9I5-I6. 
to get an expression of the will of a majority of representatives of the people which is taken as the will of a majority of the people-unless the legislature decides against the execuThe Electorate as Final tive; (3) in the event that decision is against the executive, to provide for an appeal directly to the "electorate." This last step in the procedure is called "dissolution," and has been adopted to take both the question under discussion and the parties themselves before the voters to determine what policy and party advocate will be supported by a majority of the "electorate." By use of such a procedure the budget becomes the most important constitutional method for making the government responsible and responsive to the popular will.

In the foregoing we have considered only the general problem of control in the estimating and granting of funds for government needs. With funds once granted the problem presents itself of organizing such a system of control as will ensure that the moneys granted will be expended in an efficient and economical manner. Reference is not here made to that kind of control involved in ensuring that moneys voted shall be expended strictly in accordance with law; and that no money shall be paid out except for services actually rendered or goods received. This control is that performed through a system of audit that will receive attention in another part of this report. The control here considered is that involving the exercise of personal discretion.

Generally speaking, control involving personal discretion is exercised at three points: (I) In the legislature; (2) in the central financial department of the government; and (3) in the several departments or where account of the expenditure is made.

The estimates of financial needs should be, and in most cases are, prepared and submitted in great detail to the end that the appropriating authority may have before it complete information regarding the way in which prior grants have Control Should Be Consistent With the Use of been expended, and the items entering into the total sums 


\section{BRITISH FINANCIAL ADMINISTRATION}

requested for the ensuing year. This itemization constitutes the justification on the part of the several services for their requests. It by no means follows that because these detailed data are submitted the act of appropriation should enter into the same itemization. Did it do so, and were no provision made by which it might be departed from, the result would be that little or no discretion would be left to the spending departments and the latter would at times be seriously embarrassed in meeting contingencies as they arise. It is evident that a wide range of choice is here presented to the legislature as regards the policy to be pursued by it: (I) It may have the appropriation act or acts in substantially the same

Forms of Acts of Appropriation

Legislative Encroachment on Executive Discretion form and detail as the estimates; (2) it may have the appropriation in substantially this form but provide that the assignment of funds may be departed from under certain conditions or within certain limitations; (3) it may make the appropriations in substantially this form, but provide that the assignment of funds may be departed from upon the approval of some designated authority being first obtained; or (4) it may pass the appropriations in such a form that the sums voted are allocated to main heads only, thus leaving to the spending departments large discretion in respect to the details of expenditure.

The foregoing does not exhaust the possible diversities of practice. The enumeration that has been made has had for its purpose merely to bring out that here, at this initial stage of the proceedings for rendering funds available for expenditure, there is presented the important question as to where discretion in respect to the expenditure of funds voted shall rest. If the legislature makes the appropriations in detail and makes no adequate provision by which departure from this assignment may be had, that body assumes the major responsibility for controlling the expenditure of funds. The policy of control here followed is that of attempting to control by specification in advance, and the minimum of discretion is left to the expending authorities. This is the policy which 
is generally followed by the Congress of the United States in providing for the expenditure of the Federal Government, though there are important exceptions to the rule. As will be seen hereafter, the appropriation system of the British Government rests upon the contrary principle, that of having the appropriation of funds binding only as regards certain large heads and of permitting the exercise of a wide discretion on the part of the executive in respect to the employment of the funds under these general heads.

The adoption of this second policy means that provision must be made for the exercise of control at some point over the departments actually expending the money. To leave to the latter complete freedom to spend the money voted as they see fit, except as controlled by the appropriation to the few main heads, would manifestly be unwise. The first point at which this additional or secondary control may be exercised is in the finance department. A very important feature of any financial system following this second principle of appropriation by main heads only is thus the extent to which, if at all, the legislature has delegated to the central financial department of the government the authority to exercise a control or supervision over the several spending departments in respect to the utilization of the funds that have been granted to them, the machinery that has been provided through which this control may be exerted, and the manner in which it is in fact exercised.

A reading of this report will bring out the fact that in respect to this matter the English Government has developed a system of remarkable efficiency. To understand the significance of this system one has to appreciate that the whole theory of the relationship that exists between the legislative and the executive under the English constitutional system is fundamentally different from the one that obtains in the government of the United States. Our administrative system is based on the principle that, as regards both financial affairs and the general conduct of work, the several departments are

Administrative Control Through a Finance Department
Fundamental Difference Between English and American Systems 
completely independent and coördinate units, each working under the direct authority of Congress. Little or no provision exists for the exercise by one department of any authority over other departments, and little provision is made for the exercise of central executive control over details of administration. The only possible exception to this is the power that the Comptroller of the Treasury has of prescribing the manner of keeping and rendering accounts. Even this power has been interpreted as referring only to the keeping and rendering of such accounts as are necessary in order that the comptroller and auditors may properly perform their duties. So firmly is this principle established that any attempt on the part of one department to supervise or control the affairs of another would be strenuously resented. It is even doubted whether the President himself has power of general direction and control over purely administrative matters except as such powers have been expressly granted to him by statute.

In England, on the other hand, the principle is definitely recognized that the Treasury Department has large powers of The English control over the financial transactions of all the other adminTreasury istrative services. In a way it may almost be said that this department is an agent or organ of Parliament for controlling the administrative services rather than a part of the administrative service proper. This power of the Treasury, the means through and the manner in which it is exercised, will constitute one of the most important points considered in this report.

Control over Expenditures

The next point at which control over expenditures may be exercised is in the offices of the directing heads of the several departments. In the same way that powers may be given to such heads to revise the estimates submitted to them by the heads of the services comprehended under their departments, so authority may be given to them to control in whole or in part the expenditure of the funds finally granted. This control may be exercised in the way of allotting to subheads the 
moneys appropriated under main heads, or authorizing transfers from one subhead to another, etc. ${ }^{1}$

In the foregoing we have considered the problem of control from one standpoint only, that of the determination of the manner in which funds voted shall be allotted to specific activities. There remains another feature in respect to which control may be exercised that is no less important. Reference is had to the matter of control over purchases and the use of things bought by the agencies created by the government for doing work. The things bought fall in two main categories: (I) Personal service, and (2) non-personal service; such things as transportation, quarters, equipment, supplies, etc. Here we have directly to do with expenditures for the things which are to be acquired for use. Control in respect to what work shall be performed can of course bring about economy in ensuring that no work not of real necessity or utility shall be undertaken. It can reduce or eliminate the enormous waste of funds resulting from the performance of work for which there is no real public need. Especially can it prevent in whole or in part the misapplication of things purchased in the operation of public works of no or of doubtful utility. This control is at most only collateral, however, in that a waste or misapplication of funds in making purchases can take place in the carrying through of works concerning the utility or necessity of which there is no question. In performing such work an unnecessary number of persons may be employed, excessive salaries may be paid, supplies may be purchased at excessive rates, and, generally, expenditures may be made in a wasteful manner. If efficiency and economy are to be secured in respect to these factors some provision must be made for the exercise of due supervision and control over specific expenditures of this character. ${ }^{2}$

${ }^{1}$ For a consideration of the problem of exerting control in this way see W. F. Willoughby: "Allotment of Funds by Executive Officials, an Essential Feature of any Correct Budgetary System." Proceedings of the American Political Science Association (1912).

${ }^{2}$ See Municipal Research, Nos. 57 and 58. 


\section{BRITISH FINANCIAL ADMINISTRATION}

Administrative Means of Control over

Purchases
A Study of Methods of Control

Consideration of the problem of efficiency and economy in the purchase of personal service and supplies brings up the need for well-organized civil service and supply departments -divisions for administering the two categories into which all ordinary expenditures for current operation and maintenance can be made to fall. If the study of the financial system of a government is to be complete, due attention must consequently be given to: (I) The system provided for the determination of the number of employees that may be engaged, the manner of their recruitment, their classification, compensation, condition of service, etc.; and (2) the system provided for the purchase, inspection, warehousing, requisition, issue and consumption of stores. Here, or elsewhere, economy and efficiency can be secured only by the provision of means that will ensure a rigid supervision and control over the spending units. In the present report not a little attention will be given to this matter.

We have considered this problem of control at some length, since there is no feature of financial administration that is of greater importance. It is moreover the feature to which the commission devoted its chief attention in the study of the English financial system. Especially did it seek, through personal interviews with officials concerned with all the operations involved, to determine not only the extent to which provision for control existed, but the effectiveness with which this control was in fact exerted. The results of its inquiries showed that this problem had been worked out with exceptional thoroughness. In no other respect is the English system more worthy of careful study. Should this report serve no other purpose than that of making known the means by which England has successfully met this primary requisite of a sound financial system, it will, it is believed, far more than justify the expense and labor involved in its preparation. 


\section{CHAPTER II}

\section{SOME FUNDAMENTAL FEATURES OF THE ENGLISH SYSTEM OF FINANCIAL ADMINISTRATION}

Fiscal Year; Theory of Public Accounts; Expenditures Made Only in Pursuance of Appropriation by Parliament; Historical Development of the Present Appropriation System; Separation of the Personal Revenues and Expenditures of the Sovereign and Those of the State; The Civil List; The Consolidated Fund; The Exchequer; The Collection and Expenditure of Funds Authorized by Parliament Only Upon the Request or Approval of the Crown; Distinction between Permanent and Annual Appropriations; Consolidated Fund Services; Supply Services.

In our analysis of the problem of the financial administration of a government the several operations involved were grouped under the three heads of receipt, custody, and disbursement of public funds. Although, for purposes of completeness, mention was then made of the problems having to do with the raising of revenue, no attempt is made in this report to give an account of the manner in which these problems are met by the Government of Great Britain. The investigation was undertaken for the purpose of determining the principles and methods employed by that country in the voting and spending of treasury resources. Our report therefore will cover only the operations having to do with the custody, voting, and disbursement of public moneys.

In general our account will follow closely the order of operations outlined in our analysis. Therefore a description will first be given of the system made use of by the English Government for the custody of its funds. In order that this system, as well as the subsequent operations having to do with the voting and expending of moneys, may be understood, 
it is necessary that some account should be given of certain fundamental features that lie at the very basis of the whole English financial system.

The Fiscal Year. An essential feature of any financial system is that some definite period shall be adopted to which estimates, accounts and reports shall relate; otherwise no methodical provision can be made for future financial needs, and for rendering accounts of past operations. The period selected by practically all modern nations has been a year. This year, however, does not necessarily correspond with the calendar year. In the United States the financial year, or "fiscal year" as it is technically called, runs from July I to June 30. Strange as it may appear, it was not until 1854 that England adopted a fiscal year to which all of her financial transactions should relate. Prior to that date she had three different financial years, one for estimates, one for appropriations, and one for accounts. ${ }^{1}$ By act of that year the period April $\mathrm{r}$ to March $3^{\text {I }}$ was made the fiscal year for all purposes. ${ }^{2}$

Theory of Public Accounts. Another important feature affecting the whole problem of public financing is that of the system employed in keeping the government's books of account. In general a government has to choose betwen two systems: (I) That in which the accounts of a year are based upon the principle of showing all the resources accruing to the government, and setting up against these resources all obligations incurred-treating cash received simply as collections of ac-

Two

Systems of Public Accounting counts or revenues receivable, and cash disbursed as the payment of expenses or accounts payable; and (2) that in which the accounts of a year show only the money actually paid into or out of the treasury during the year, whether such payments did or did not pertain to that year. To illustrate: The first system would set up the revenues of each year sepa-

${ }^{2}$ See Henry Higgs: Financial System of the United Kingdom, p. I. 'Act 17 and 18 Vict', c. 94, s. 2. 
rately, and money received on account of taxes levied for the year I9I4, but actually received in I9I5, would be considered as collections for the fiscal year I9I4; the second system would consider all cash collected during I9I 5 as belonging to that year. In like manner money paid out of the treasury in I9I 5 to settle obligations incurred in I9I4 would, under the first system, be considered as the payment of the liabilities of the year I9I4; under the second system all payments during I9I 5 would be considered as belonging to that year. The first of these two systems thus rests upon the theory of showing all revenues accrued and expenses incurred for each year and the transactions pertaining to that year-thereby setting up assets and liabilities and an operation account; the second system rests upon the theory that no information is needed except transactions of cash, with the balance at the beginning and the end of the year. The first thus rests upon an accrual basis and the second upon a cash basis. The first is adapted to giving all the information needed for the management of the whole estate, including the cash; the second is adapted only to treasury management.

Each of these systems has its advantages and disadvantages. The first is more complex, but furnishes all the information needed for central control over the entire management; the Advantages and Disadvantages of second is simple, but lays no basis for accurate comparisons of cost. Cash systems may be so operated as to give approximately accurate comparisons of cost by keeping the collections and payments belonging to each year's accruals separate. This means that the accounts of each year are kept open until all the collections of revenues accrued and all the payments of liabilities incurred during that year have been made. This is the system employed by France; ultimately it gives a close approximation of revenues and cost, but the result is long delayed. Other nations, such as the United States and England, are less exact in determination of the years to which the cash transactions are to be assigned to get at comparisons of cost. It would take us too far astray to attempt anything 
like a thorough discussion of this question at this place. We shall have to content ourselves with the general statement that, while each gives the same result in showing treasury movements and conditions, the French system gives more scientific information about the results of management. It has the great disadvantage, however, that under it the accounts for a year must be kept open for several years after the year to which they relate has closed, and thus the results are not promptly available. By not attempting, through central accounts, to obtain this information, the English and American systems have the technical advantage of permitting the books to be closed immediately upon the termination of the year, and of making final reports, such as they are, to the public without delay. ${ }^{1}$ In the United States an attempt is made to obtain the added information on the expenditure side by keeping the appropriation accounts open till a later datethereby enabling the central accounting officers to make supplementary statements later, from time to time when called for.

A Fundamental Principle of the British Constitution
Expenditures Made Only in Pursuance of Appropriations by Parliament. It is a fundamental principle of the British constitutional system, as it is of the American system and of most systems of nations having what is termed "constitutional" government, that no expenditure of public funds shall be made except in pursuance of express authorization therefor by an elected representative body possessing the legislative power. It follows, therefore, in England that parliamentary authority must be found for all expenditures. This authority is usually found in annual or other formal appropriation acts, though it may be contained in permanent statutes.

It is a remarkable fact that, though the idea of supreme control over the public purse by the House of Commons was

${ }^{2}$ For an excellent discussion of this subject see H. C. Adams: Science of Finance, pp. 20I-21 I. See also René Stourm: Le Budget, pp. I I-136. Prof. Adams believes that, though difficult, it would be possible to employ a system that would combine the advantages of both systems. 
early established as one of the fundamental principles of the British constitutional system, no means for making this control really effective were put into execution until well into the nineteenth century. The fact is that it was not until this late date that the expression, "control of the public purse," came to have the meaning that it now has. During all the earlier period when Parliament was seeking to exert its power over the Crown in respect to financial matters, it had in view not the direction of how public moneys should be spent, but the limitation of the total amount that the Crown might demand of the people in the way of taxation for governmental purposes. Control at this time meant a control over revenues and receipts rather than the expenditure side of government operations. The chief solicitude of Parliament was the protection of the taxpayers. It hardly had the conception of taking to itself the determination of the manner in which funds, the raising of which was once authorized, should be expended. Discretion in respect to the expenditure of funds was recognized as a prerogative of the Crown. It was the duty of the Crown to administer the affairs of the country. Anything approaching the modern practice of stating in detail how money granted for the support of the Government should be spent would have been looked upon, at that time, as an unwarranted intrusion of the legislative branch into the executive branch of the Government.

Only gradually, step by step, has this principle been modified and the present practice established. According to this Parliament determines not only what and how public revenues Evolution of Parliamentary Control Complete shall be obtained but how this revenue shall be expended. Even now, as will later appear, the most characteristic feature of the appropriation system of Great Britain is the extent to which discretion is still left to the Executive in respect to the expenditure of the funds granted. Though Parliament still refrains from giving instructions in detail regarding expenditures, it must nevertheless be recognized that the evolution from the old to the modern principle of control is com- 


\section{BRITISH FINANCIAL ADMINISTRATION}

plete. The old theory that the function of Parliament ceased with the determination of the total amount of funds that should be placed in the hands of the Crown for the conduct of public business has been wholly abandoned. It is now universally recognized that the power of Parliament in respect to expenditures extends to the determination in the greatest possible detail of the purposes for and manner in which the public money shall be spent. The fact that it does not exert this power to the full is due simply to the belief that to do so would be a mistake. It stops short of this because it believes that the Crown is in a better position to determine these details than itself, and that a too minute specification would unduly tie the hands of the Executive and lead to inefficiency.

The Starting Point

Historical Development of the Present Appropriation System. To understand present conditions it is desirable to trace, at least briefly, the steps by which this evolution of the function and power of Parliament in respect to expenditures has been accomplished. The starting point in tracing this evolution is the recognition of two things: (I) That at the outset there was absolutely no distinction between the revenues of the Crown and those of the State; and (2) that at this time these revenues were only in small part obtained from taxation imposed upon the people. For the most part the public income was derived from Crown lands, feudal dues, and the like. "The first point that we have to seize," writes F. W. Maitland, "in dealing with this subject historically is that in old times the national revenue was very really the king's revenue, or, to put it in another way, there was no national revenue; whatever money came to the king's hand was his to deal with as he pleased, whether it consisted of the rents of his demesne lands, or the profit of the feudal tenures, or the outcome of the aids or subsidies granted to him by the great council of the nation."1

${ }^{1}$ F. W. Maitland: Constitutional History of England, p. 430. 
In normal times this feudal income was sufficient to meet the personal expenses of the king and his court and the general expenses of the Government. It was only as wars broke out that need arose to resort to taxation. When levied, taxes were deemed to be special levies for the occasion only and to meet the special emergency then existing. "Another point of importance is this, that during the Middle Ages permanent taxes are very seldom imposed. In general a tax is granted just for this occasion only: The king is granted a tenth of movables, or a customs duty, or it may be a poll tax just to meet the present demands upon his resources. Sometimes taxes are granted for two or three years to come, but this is rare." 1

These two points are significant from the standpoint of parliamentary control since, with the development of the two principles that taxes were in general levied not as a general source of income but as a means of securing funds for a particular purpose, and that no such levy could be made except with the approval of Parliament, there naturally arose the corollary that Parliament should specify the use to which the income derived from a tax authorized by it should be put. The first form of appropriation was therefore that of appropriating an indeterminate sum, the proceeds of a certain tax, to a certain purpose. Maitland mentions as the earliest cases where this was done the taxes authorized in 1348 for defense against the Scots and in 1353 for the prosecution of the war then in progress.

This specification of purpose was not always made, and, when made, no adequate means existed for ensuring the stipulations so made being carried out. Not until the RevoLimitation of Expenditures lution in 1688 may this principle of granting funds for particular purposes be said to have been firmly fixed. Its establishment grew out of the contest between Parliament and the Stuarts. "In I665 Charles II asked a very large sum of money for the Dutch war, and consented that a clause should be

${ }^{1}$ Maitland: Constitutional History of England, p. I82. 
The Present Appropriation System

Its Gradual Evolution

inserted in the act declaring that the money raised under that act should be applicable only to the purposes of the war. This was an important concession, and similar appropriations were afterwards made during his reign. .Since the Revolution the practice has, I believe, never varied; in granting money to the crown, parliament has appropriated the supply to particular purposes more or less narrowly defined." 1

In considering this statement of Prof. Maitland we must, however, bear in mind that what was here established was something which did not approach the modern appropriation system. In the first place the king had, and continued to have for many years, a large income which did not come to him as the result of a grant from Parliament, and over the expenditure of which he consulted no will but his own. In the second place, the appropriation grants went no farther than to designate that they were to be devoted to certain large purposes, such as the prosecution of a certain war, the maintenance of an army, the construction of a fleet, etc. "The great financial change made at the Revolution," writes Lord Welby," "related to the charge of the Navy and the Army. The Revolution introduced annual Sessions of Parliament, the French war led to annual Votes in Supply for Navy and Ordnance services, and these Votes were formally sanctioned by Lord Somers' Appropriation clauses. It should be added, for the sake of accuracy, that even in the time of William III. a few Votes were taken annually for services of a civil character. These gradually increased in number, but they were comparatively insignificant in amount until the latter part of the reign of George III. It will be seen, then, that the control of Parliament over public expenditure began with the Revolution, but that that control extended only to expenditure on Army, Navy, and Ordnance. The reality of the control was

1 Maitland: Constitutional History of England, p. 433.

"Memorandum on "The Control of the House of Commons over the Public Expenditure." Report of the Select Committee on $\mathrm{Na}$ tional Expenditure (1902), Appendix No. 13, p. 228. 
proved by the reduction of the Army enforced after the Peace of Ryswick by the House of Commons against the wishes of the King. The control, however, was limited in its character. Estimates for the military services were laid before the House of Commons, and upon these estimates the House of Commons voted an amount for each service. There was only one vote for the whole of the Navy service until i798. In Anne's reign the Army grant was divided into two or three Votes, but in both services there grew up a practice of expending large sums without the previous sanction of Parliament on 'extraordinaries,' and a vote for these extraordinaries was submitted for the sanction of the House of Commons in a subsequent Session. The control exercised through the Votes in supply was therefore imperfect, and left a great latitude to the executive Government, of which the Government did not fail to avail itself.".

Before anything like a general appropriation system, that is, one under which Parliament should specify with reasonable particularity how the public revenues should be spent, two reforms had to be accomplished. The first of these was that a clear separation should be made between the personal revenues and expenditures of the sovereign and those of the State; the second, that the revenues of the State should constitute a general fund from which allotment should be made to specific purposes. The first of these was accomplished through the creation of what is known as a "Civil List," the second through the establishment of the so-called "Consolidated Fund." Before proceeding further. with our historical sketch of the development of the present appropriation system it is necessary therefore to say a few words regarding the circumstances under which these two reforms were accomplished.

Separation of the Personal Revenues and Expenditures of the Sovereign and Those of the State: The Civil List. As The Civil List

Successive Steps in Development has been pointed out, until comparatively modern times the 


\section{BRITISH FINANCIAL ADMINISTRATION}

Grant of

Hereditary

Excise
Fixed

Amount for Support of Crown

king was in possession of important revenues not produced through taxation and not, therefore, coming to him as a grant from Parliament. Even after the principle was established that, as regards the grants by it, Parliament could determine the manner in which funds should be expended, this income remained at the absolute disposition of the sovereign to do with as he pleased. From this income, however, he had to defray not only his own expenses and those of his court but all of the ordinary expenses of government.

At the Restoration the amount of this income was greatly reduced through the abolition of many of the heaviest feudal burdens. To compensate the king for this loss of revenue there was granted to him the proceeds of what was known as the hereditary excise, a special permanent tax upon beer, cider, spirits, and certain other articles. Apart from other features this act is of interest as being the first example of the imposition of a permanent tax.

This arrangement was continued when William III came to the throne and, in addition, a new tax, a tonnage and poundage tax, was granted to him for life. To this grant there was, however, imposed an important condition. The act sets forth that it is the intention of Parliament that the king should have an income of $£ 700,000$ per annum and that, should his income exceed that amount, no use should be made by him of the excess without the authority of Parliament. This, says Maitland, ${ }^{1}$ was the first time that the notion of a Civil List appears on the statute book.

The next step in the evolution of the Civil List was taken when George III came to the throne. On his accession he consented to give the greater part of the hereditary revenues of the Crown in return for the grant to him of a yearly sum of $£ 800,000$. In this act a long step was taken towards the principle of the revenues of the Crown being treated as national income and the expenses of the Crown as expenses which should be met through grants from Parliament. A

${ }^{2}$ Maitland: Constitutional History of England, p. 435. 
further step was taken when George IV became king. The arrangement made with his predecessor was continued, with the minor difference that the amount of the grant was increased to $£ 850,000$ per annum, and the fundamental difference that, for the first time, a distinction was made between the amount that should be deemed the king's for his personal use and that which should be devoted to the support of the Government. The former amount was fixed at $£ 60,000$ per annum.

Slightly different arrangements were made with William IV and Victoria when they came to the throne, these differences all being in the direction of drawing more clearly the lines between the personal expenses of the sovereign and Government expenses proper, and in establishing the principle that all expenditures, including those personal to the sovereign, should find their authority in a grant of Parliament. The result is that at the present time, and one may say since the accession of William IV, the sovereign receives a salary out of which he must pay all his personal expenses and those of his family and court. The total amount of the Civil List at the present time, as set forth in the "Finance Accounts" for

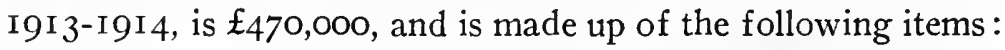

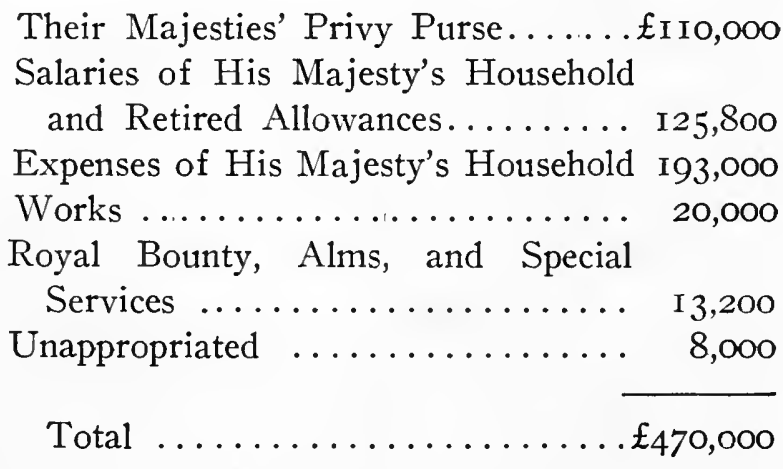

This amount is carried as a permanent continuing charge upon the Consolidated Fund, the same as the items for the 
payment of the interest on the public debt, the salaries of judges, etc. ${ }^{1}$

An Essential to the

British System of Control

The Consolidated Fund. In making a clear distinction between the possessions of the sovereign and those of the nation, Parliament laid one of the foundation stones upon which to rest the structure of real legislative control over national income and expenditure. A second stone was laid in 1787 by the establishment of the principle that there should be one general fund into which all the revenues of the crown should be paid and from which all public disbursement should be issued.

"In 1785 [writes Mr. Henry Higgs] ${ }^{2}$ the Commissioners of Public Accounts called attention to the intricacy of the system under which various public charges were earmarked against particular sources of revenue. Thus, for example, no fewer than seventy-four charges involving seventy-four separate accounts were imposed upon the Customs revenue, the Militia charges were defrayed from the Land tax, and certain hereditary annuities were met out of the Post Office revenue. To sweep away such complications the Commissioners recommended that there should be formed 'one Fund into which shall flow every stream of the public revenue and

${ }^{1}$ Higgs in his "Financial System of the United Kingdom," p. 54, quotes the following interesting passage from Macaulay's "History of England," Chap. xv, regarding the use of the term "Civil List": "The expenses of the Royal Household are now entirely separated from the expenses of civil government; but, by a whimsical perversion, the name of Civil List has remained attached to that portion of the revenue which is appropriated to the expenses of the Royal Household. It is still more strange that several neighbouring nations should have thought this most unmeaning of all names worth borrowing." The historical justification for the English use of the term is, as we have seen, that in early days civil expenses were a charge upon the revenues of the Crown, military being largely met from grants by Parliament.

${ }^{2}$ Henry Higgs: Op. cit., p. 18. 
from whence shall issue the supply for every public service." "

This recommendation of the Commissioners of Public Accounts was approved by Parliament. By the so-called Consolidated Fund Act of 1787,1 provision was made that there should be established a single fund, to be known as the Consolidated Fund, into which all public revenues should be paid, and out of which all public expenditures should be met. A similar measure in reference to the revenues and expenditures of Ireland was enacted in 1816 and the two Consolidated Funds were further consolidated into one Consolidated Fund of Great Britain and Ireland. ${ }^{2}$

It is difficult to overvalue the importance of this action. It constitutes one of the greatest measures of financial reform accomplished by Parliament up to that time. As long as the Importance of the Consolidated Fund system of assigning particular receipts to particular purposes prevailed, it was manifestly impossible for Parliament to exercise any close control over the administration of the public finances. Certainly it was impossible to secure that annual consolidated statement of public revenue and expenditure, in connection with an estimate of future needs, which is the foundation upon which any proper budgetary system must rest.

In view of the manifest advantages of this system it is difficult to understand why England, having once adopted it, should afterwards depart from it. As will hereafter be pointed out, Parliament has directed that certain receipts of the Government shall not be carried into the Consolidated Fund, but shall be used directly by the services collecting them in the way of "appropriations in aid" for meeting their expenses. This is a matter which will be considered at some length when the subject of estimates and appropriations is taken up for special consideration. We only mention it here as a procedure which

${ }^{1} 27$ Geo. III, chap. I3.

2 Maitland: Constitutional History of England, p. 44I. 
seems to be an unfortunate departure from a sound principle of public finance.

The Exchequer. The term "Consolidated Fund" is employed to describe the general fund into which, with the exception that has been noted, all public revenues are paid and out of which all public expenditures are met. This fund stands to the credit of the "Exchequer," the latter being the term employed to designate the public treasury. The custodians of this account are now the Bank of England and the Bank of Ireland. The origin of the term "Exchequer" and the early system employed for the custody and control of public funds is interestingly told by Mr. Thomas Gibson Bowles, a member of Parliament and a high authority upon matters of public finances, in his testimony before the Select Committee on National Expenditure (1902). ${ }^{1}$

Origin of the Exchequer

"As to the origin of the present system, of course an Exchequer-that is to say, a place for keeping the King's cash-has always existed in this country from the very earliest times. But the Exchequer properly so called had its name brought over for it from Normandy with the Conquest, and I believe the name is derived from the checkered cloth upon the table of the place where the cash was kept which was used in order to facilitate calculations. The Exchequer, then, is the place where the King's Revenue was received, where it was kept, supervised and controlled, and from whence it was issued. It was kept there and managed there. It was at first the actual coin that was received there by tale and weight. There were three officers of Exchequer, each of whom had a control over the issue of the money, for the money was kept in chests, each chest having three locks and each of those officers having his key to one of the locks. One of those officers was called the Teller, who was the cash-

${ }^{1}$ Report (1902), p. 63 . 
ier who received and issued the money; then there was the Clerk of the Pells, who recorded on a pell or parchment all receipts and issues; and then there was the auditor, who examined the records, and whose duty it was to see that no money was issued except in accordance with law, and with the sanction of Parliament."

This was the system that existed until well into the nineteenth century, though certain changes were of course made in respect to the actual custody of the cash. In I834 the whole system for the administration of the public finances was thoroughly overhauled. One of the reforms thus accomplished was the provision that thereafter all public revenues should be paid into the Banks of England and Ireland to the credit of the Exchequer account, that is, to the Consolidated Fund. As there is no separate Exchequer account in Scotland, the duty of receiving public moneys and paying them over to the Bank of England is performed by the six Scotch banks in rotation of a year each. The term "Exchequer" as one to designate the national treasury is retained, the Bank of England and the Bank of Ireland being merely substituted as the strong box for the keeping of the public treasure. The Bank of England and the Bank of Ireland, it should be noted, are mere bankers of the Government. Their duty is confined to that of receiving the public revenue and paying it out to officers who are charged with the actual responsibility of settling and paying public obligations. They take the place of the Teller under the old cashbox system.

The Collection and Expenditure of Funds Authorized by Parliament only upon the Request or Approval of the Crown. We have seen that the principle is now firmly established that no burden in the way of taxation or otherwise shall be imposed upon the people and no expenditure of public funds shall be made until Parliament has given 
Location of Executive Responsibility

The Rule Rigidly Enforced

its express sanction therefor. No feature in the whole constitutional history of England is more noteworthy than the fact that the House of Commons, while steadily insisting upon the establishment and maintenance of this principle, has at no time sought to make of itself the organ through which the financial program of the Government, either as regards receipts or expenditures, should be formulated. From the beginning it has interpreted its function as that of passing upon proposals emanating from the Crown. It was the duty of the Crown to declare what were the financial needs of the nation and how these needs should be met; the duty of the House of Commons lay in the approval or disapproval of the plans as laid before it.

This rule is rigidly enforced. It applies not only to the annual finance and appropriation acts by which the collection of taxes is authorized and the grant of funds made, but to all cases where money is required for any purpose. It prohibits the introduction, or at least consideration, of any bill or resolution the provisions of which, if enacted, will impose a charge upon the public treasury, until the approval of the Crown, expressed through one of the ministers, has first been received. Furthermore, it rules out any amendment to a proposal submitted by the Crown having for its purpose the increase of the sums asked for by the latter. ${ }^{1}$

The rules governing this matter are now found in Standing Orders Nos. 66 and 68 of the House of Commons, both of which date from the beginning of the eighteenth century,

${ }^{1}$ To this statement that the initiation for all expenditures must come from the Crown there is one exception. Occasionally a case presents itself where it is desired to make a special appropriation for a particular object, such as the erection of a monument to a distinguished person, or the grant of a sum of money to one who has rendered some great service to the nation, and it is deemed more appropriate that the proposal to make such an expenditure should come from the House. In these cases the House passes what is known as an Address to the Crown asking that the grant be made and stating that "this House will make good the same." All such sums must, however, be formally voted in committee as all other appropriations. 
though their wording may have undergone some slight alteration. Their present wording is as follows:

"66. This house will receive no petition for any sum relating to public service, or proceed upon any motion Standing Orders for a grant or charge upon the public revenue, whether payable out of the consolidated fund or out of money to be provided by parliament, unless recommended from the Crown."

"68. This house will not receive any petition for compounding any sum of money owing to the Crown, upon any branch of the revenue, without a certificate from the proper officer or officers annexed to the said petition, stating the debt, what prosecutions have been made for the recovery of such debt, and setting forth how much the petitioner and his security are able to satisfy thereof."

It is hardly necessary for us to point out the overwhelming importance of the principles embodied in these rules as a means of preventing ill-advised and wasteful expenditure of public funds. At one stroke it renders impossible the enormous abuses which prevail in the United States arising from the right possessed by individual members of Congress to propose and secure the consideration of measures calling for an appropriation of public funds. The exercise of that right, in conjunction with the device of "log-rolling," has not only given rise to the recurrent scandals of the "pork-barrel" public buildings and river and harbor bills, but has destroyed all possibility of framing and adopting a consistent and effective scheme or program of public expenditures. Under the British system each demand for funds/originates with the head of the service for which the funds are requested, and thus represents the judgment of the person most competent to determine the real needs of the service. Under the American system demands for funds may, and often do, originate with 


\section{BRITISH FINANCIAL ADMINISTRATION}

individual members of Congress having little, and, at best, inadequate, knowledge of the needs of the services for which they are intended. What is worse, they have no direct interest in the efficient and economical administration of such services. Their interest is in the localities to be served, which interest may be diametrically opposed to the interest of the services and of the public as a whole. In many cases money is appropriated in pursuance of proposals thus initiated, notwithstanding the fact that the heads of the services affected protest vigorously that they have no need for such money or for the services to be furnished by such funds.

Contrast

with

American

Practice

Executive Requests; Parliament Reviews and Grants

Under the British system responsibility is definitely located with an officer who can be, and is, held to a rigid account of the manner in which the funds asked for are expended. Under the American system the enforcement of any effective system of securing responsibility and accountability is impossible. This is an old story and the commission will not dwell upon it further. It would not have been proper, however, to have omitted making at least this brief mention of the great advantages, both theoretical and practical, which the British system has over the American system.

\section{Distinction Between Permanent and Anmual Appropriations.} To every government there is presented the problem of determining the extent to which it is desirable that the revenue to be raised and the expenditures to be authorized shall be determined by general statutes continuing in force until modified or repealed, or shall be a matter to be annually considered and acted upon by the fund-raising and granting authority. Theoretically the principle of parliamentary control renders it desirable that each year Parliament should make a general examination of all the financial resources and needs of the Government and decide upon a revenue and expenditure program for the year to ensue. To the theoretical advantages of this principle there are, however, certain practical objections. From the revenue side there are obvious disadvantages 
in constantly modifying the taxation system or even in raising the question of its modification. From the expenditure side there are certain obligations of the Government which, for reasons that will be stated, it is undesirable to submit to the hazards of an annual determination. The most important of these obligations are those in respect to the meeting of which the public faith has been pledged. Of this character are the interest on the public debt and payments on account of annuities, pensions, etc. Another class of obligations falling in this category is that represented by judicial salaries. Here the motive for making the authorization of the payment a permanent and continuing one is that of giving the judges greater independence of legislative and executive influence than they would have if their salaries had to be voted each year. Finally, there is something to be said in favor of adopting, as regards certain expenditures, a program that will extend over a considerable period of time, and also of relieving the legislature from the consideration of matters regarding which there is little or no opportunity for difference of opinion in respect to the action to be taken.

In the United States this difference between appropriations which should be voted specially or annually and those which should be provided for by general statute is clearly recognized by the distinction which is made between permanent or continuing appropriations and annual appropriations. In England the same distinction is made, but the terms employed to designate the two are different. Appropriations falling under the first head are termed "Consolidated Fund Services," and those falling under the second head "Supply

Distinction Between Continuing and Annual Appropriations Services." This distinction is of prime importance, for it must be remembered that in all the discussion that follows as to the manner in which estimates are prepared, submitted, and acted upon, reference is had solely to the supply services. This means that the documents relating to these transactions, the estimates themselves, the memoranda and com- 


\section{BRITISH FINANCIAL ADMINISTRATION}

parative tables accompanying them, and the "appropriation accounts" submitted to the House by the Comptroller and Auditor General giving audited expenditures, do not make a complete presentation of estimates or expenditures for all the expenses of government, but only for those covered by the Supply Services. This being so, it is important to determine the principles upon which this classification is based and the character of the items that are assigned to each class.

Consolidated Fund Services. It has been pointed out that the principle of parliamentary control over expenditures demands that the general rule be that provision shall be made annually for the needs of the ensuing year and that all departures from this rule shall be in the nature of exceptions for which an adequate justification shall exist. It is a mat-

What Appropriations Are Included ter of importance, therefore, to determine the manner in which this rule has, in practice, been carried out in the British system. The following table, taken from the "Finance Accounts" for the year I9I3-I9I4, gives a recapitulation of the items covered by the Consolidated Fund Services:

\begin{tabular}{|c|c|c|}
\hline Receipts & $£$ s. d. & d. \\
\hline 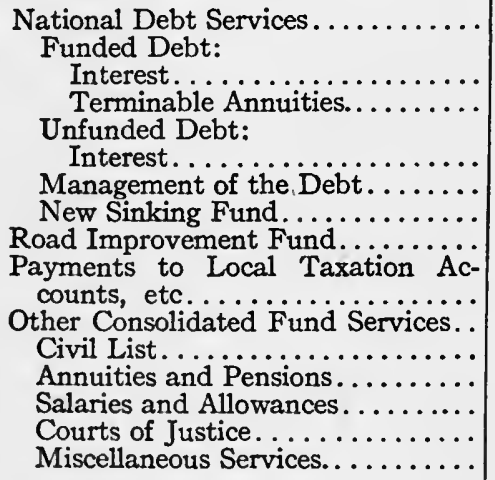 & $\begin{array}{r}14,787,108-16-2 \\
3,202,026-12-5 \\
\\
1,115,849-18-7 \\
166,529-19-9 \\
5,228,484-13-1\end{array}$ & $\begin{array}{l}1,394,951 \\
9,734,127-10-6 \\
1,693,890-6-10\end{array}$ \\
\hline TotaL................ & & $37,322,968-17-4$ \\
\hline
\end{tabular}


The total issues from the Exchequer during the year were f239,752,763-5-IO. It will thus be seen that the Consolidated Fund Services represented approximately one-sixth of the total issues, the remaining five-sixths being accounted for by the Supply Services.

The foregoing table is supported by other tables in the report in which are given the details of the items entering into these tables. If consultation of these tables is had it will appear that no consistent principle has been followed by England in determining what items of expense shall be treated as Consolidated Fund Services and what as Supply Services. To bring out the inconsistencies that are here presented we cannot do better than quote the comments of Mr. Harold Cox Inconsistencies of as contained in an article entitled "The Magnificent Muddle of Department Finance," published in 1908 and republished in I9I 3 as a chapter in a book dealing with the general problem of the financial administration of Great Britain. ${ }^{1}$

After giving a table showing in some detail the items constituting the Consolidated Fund Services, he writes:

Criticism by Englishman

"This somewhat lengthy table which has been summarised from the fuller details given in the Finance Accounts, will help to show the reader how needlessly complicated are the national accounts. Take, for example, the item of $£ 16,244$ for Public Offices. This is an annuity created under an Act of I882 to pay for the sites of certain public offices. It is charged upon the Consolidated Fund, and buried out of sight under the head of 'Miscellaneous Services'; but exactly similar annuities created by other acts are charged upon the Estimates of the Office of Works, where their presence helps to show what is the actual cost to the country of its public offices.

"Equally unsatisfactory, from the point of view of intelligible account-keeping, is the item of $\mathfrak{E}_{2 \mathrm{I} \text {, ooo for }}$

${ }^{1}$ Official Finance in Government Departments: A Series of Critical Comments upon the Business and Financial Methods of Government Departments. Financial Rev. of Reviews, p. 43. London (1913). 
Queen's Colleges, Ireland. These same colleges also appear in the Civil Service Estimates under the vote for education in Ireland, and receive a further grant which in the present year will be $f_{4,700}$. To pass to larger

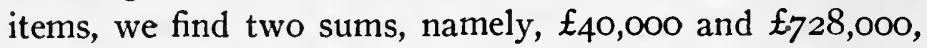
granted to Ireland under the authority of Acts of Parliament passed in 1891 and 1898 . As regards both these grants, if we turn to the Civil Service Estimates we find other sums for identical or similar services. Thus, in addition to the $\mathfrak{f}_{40}, 000$ in the above table permanently granted to Ireland for Land Purchase, the taxpayer has to provide under Class III of the Civil Service Estimates £27I,000 in the current year for the cost of the Irish Land Commission, which administers the Land Purchase Act. A further charge of $\mathfrak{E}_{12,000}$ appears in the Consolidated Fund accounts, as the above table shows, for the salaries of the Land Commission Judges. It is an elementary principle of sound account-keeping that the expenses of each service should be brought together, so that those who have a right to be interested in the expenditure may see what the full cost of the service is. Yet the cost of the system of land purchase in Ireland appears under three separate heads, which are in no way connected with one another.

"A similar criticism applies to the agricultural grant of $\mathfrak{f}_{728,000}$ a year to Ireland. In addition to this grant permanently charged upon the Consolidated Fund, the annual Estimates show a charge in the current year of £2I6,000 for the Department of Agriculture and Technical Instruction.

"As a last example take the payment of $£_{2} r_{5}, 000$ to the Indian Army Pension Deficiency Fund. This is really an army charge. It represents part of the cost of maintaining the military machine, and ought therefore to appear, not on the Consolidated Fund Accounts, but on the army estimates. 
"These examples are sufficient to show that the Estimates alone give an inadequate representation of the public expenditure. Yet, as already explained, they contain the only figures which require the annual sanction of the House of Commons. The charges upon the Consolidated Fund annually falling due are not even published until after they are paid."

To the commission it would seem impossible to deny the justice of the criticism here made. It is not merely that there is a failure to adopt and rigidly adhere to some consistent principle, but that great difficulties are thrown in the way of Parliament and the public determining the total expenditures entailed in the conduct of certain operations or of certain services of the Government. Consideration of the expenditures of the Government takes place upon the estimates submitted for the Supply Services. One naturally expects that if in such estimates items for particular purposes appear, that such items cover all the expenditures in connection with such purposes. That they do not do this and that certain expenditures of precisely the same character are provided for under the Consolidated Fund Services means that to that extent discussion takes place upon incorrect data. The evil is so obvious and the remedy so easy that it is difficult to understand why, in a system which in other respects is so excellent, a defect of this character should be allowed to continue.

Supply Services. As has been pointed out in our consideration of Consolidated Fund Services, this term is used to cover all expenditures not provided for as a permanent continuing charge upon the Consolidated Fund. Their distinctive characteristic, as regards the procedure employed in providing for them, is that they must be voted annulally in pursuance of estimates laid before Parliament. It should be noted, however, that, when voted, they are paid out of the Consolidated Fund no less than those constituting a permanent charge upon 


\section{BRITISH FINANCIAL ADMINISTRATION}

Distinguish- that fund. It is with this class of expenditures that the ing Characstudent of methods of financial administration is chiefly concerned. In the chapters that follow it will therefore be our aim to describe in detail the procedure employed in handling them. 


\section{CHAPTER III}

\section{THE ESTIMATES: PREPARATION AND SUBMISSION}

Appropriations Made Only in Pursuance of Formal Estimates; Estimates the Act of the Ministry As a Whole; The Treasury the Authority for the Preparation and Submission of the Estimates; Special Procedure for the Army and Navy Estimates; Treasury Estimates Circular; Estimates as Submitted by the Several Departments to the Treasury in Large Part but a Summation of Provisions Already Approved by the Treasury; Comparative and Explanatory Data Required; Estimates to Be Justified Though No Increase Is Requested; Preparation of Estimates Within the Departments; Examination of the Estimates by the Treasury; Transmission of the Estimates to the House of Commons; Supplementary Estimates.

As set forth in our analysis of the problem of financial administration, the point from which a consideration of the several links in the continuous chain of operations can best be inaugurated is that of the preparation by the Executive of its estimates of the financial needs of the government for the year to ensue. It is with this operation, therefore, that we will begin our study of the details of the British financial procedure.

Appropriations Made Only in Pursuance of Formal Estimates. The requirement that no proposal for the expenditure of money shall be considered that does not have the sanction of the Crown is the statement of a general principle. It is not sufficient, however, for a government to adopt a principle: Appropriate means must be provided for carrying this. Means principle into effect. In the present case this means is found in the rule which requires that all requests for funds emanating from the Executive must take the form of a formal "esti- Effect

Adopted to Carry Principle 
mate" submitted by it to the House of Commons. It thus follows that every appropriation must have back of it, and must rest upon, an "estimate." This applies not merely to the annual demand for funds for the operation of the Government during the fiscal year to which it relates, but to all requests for funds, no matter how casual they may be. If, therefore, need for money for a certain purpose suddenly arises, the only method by which the money may be obtained is by the Ministry, acting through the appropriate minister, laying before the House of Commons an estimate for the funds needed. In considering this subject of estimates it is thus important to keep in mind that this term connotes two things: (I) A careful calculation of the amount of money needed for a designated purpose; and (2) a formal document emanating from the Executive and constituting a formulated demand upon Parliament that the sum estimated for be granted to the Crown for the purpose specified. ${ }^{1}$

Estimates the Act of the Ministry as a Whole. A further cardinal principle of the English financial system is that these estimates are not submitted by the individual departments for whose use the money is intended, but must pass through, and receive the approval of, and, with the exception of the estimates for the Army and Navy, be actually submitted by the Treasury. ${ }^{2}$ The result of this procedure is that, both in theory and in fact, the request for funds is one emanating from the Executive as a whole. This is not a mere formal re-

Solidarity of Executive Responsibility quirement. It means that all requests for funds will be carefully scrutinized by an authority other than the one for whose use the funds are intended, before any formal demand for this grant will be made. When made, it becomes the act of a ministry which is responsible for the whole financial plan.

${ }^{1}$ The request for funds, under English practice, for historic reasons, takes the form of a demand.

${ }^{2}$ For all estimates, except the Army and Navy, the Treasury is the agent of the Ministry. The Army and Navy estimates are handled direct. 
This is a feature regarding which we shall have much to say in another place, where the function of the Treasury as an agent for controlling expenditure is more directly considered.

The Treasury the Authority for the Preparation and Submission to Parliament of the Estimates. We have just pointed out that requests for grants of funds represent the act of Treasury as Agent of the Ministry as a whole. This is secured by the rule that no request for funds shall be made upon Parliament until such request has received the approval of the Treasury. Furthermore, all these requests, i.e., the estimates, with the exception of those for the Army and Navy, are presented to Parliament by the Treasury. This exception in the case of the Army and Navy is merely one of form, since these estimates must be passed upon and the presentation authorized by the Treasury. In performing this function the Treasury by no means acts merely as a ministerial agent of Parliament for the assembling of the estimates and their presentation to the representative body. It is the authority which upon information obtained from administrative departments actually frames the estimates and determines what funds shall be asked for. The "Estimates," in a word, is the estimates of the Treasury, and not those of the several departments. Upon it rests the entire responsibility, subject only to the general responsibility of the Ministry for which it acts, of stating what are the financial demands of the Executive. The fact that this statement is based in large part upon requests for funds filed with it does not lessen this responsibility.

In case of differences of opinion between the petitioning department and the Treasury regarding the amount of funds to be asked for, or whether any demand at all shall be made, the final decision rests with the Treasury, subject only to the right of the department concerned to carry the matter to the Cabinet as a whole for decision. Appeals in this way are, in practice, only made when the matter in dispute is one of great importance and concerns some large matter of public 
How

Cabinet

Disputes Are Settled

Not a

Variation in Principle

Procedure Followed

policy such as the extension of a program of social reform, the increase of the Army or Navy, etc. Even here occasion for an appeal rarely arises, since all matters of general policy, with rare exceptions, are determined by the Cabinet before the work of preparing the Estimates is entered upon. The explanation of the infrequency with which appeal is made from the decision of the Treasury is found in the strong tradition that has developed that the spending departments should accept the decision of the Treasury, and the still stronger feeling on the part of the Cabinet that in all appeals brought before it the Treasury, if possible, should be supported. This is a matter of great importance. Were the practice otherwise the whole theory of the responsibility of the Treasury for estimates might easily be broken down.

Special Procedure for the Army and Navy Estimates. The exception that has been noted in respect to the submission to Parliament of estimates for the War Office and the Admiralty by these departments instead of by the Chancellor of the Exchequer does not represent any real departure from the general principle of Treasury control. The fact that the procedure followed is that of having these estimates presented by the heads of the two departments is without any lessening of the prestige of the Treasury, since no estimate can be submitted until it has been presented to, and has received the approval of, the Treasury. The procedure followed in securing this approval is, however, somewhat different from that followed in the case of the civil services.

The foregoing is clearly brought out by the following quotation from the official memorandum describing the control of the Treasury over the War Office and Admiralty, filed with the Select Committee on National Expenditures (I902). ${ }^{1}$

"Control over Estimates: This in its initial and larger stage is the control of the Chancellor of the Exchequer,

${ }^{2}$ Report of Select Committee on National Expenditure (I902), Appendix No. 3, p. 197. 
who settles first with the Secretary of State for War and the First Lord of the Admiralty, and subsequently with the Cabinet, what is approximately to be the total sum submitted to Parliament on account of Army and Navy services in any given year. If the proposed total shows any appreciable increase, the Minister will explain to what cause the demand is due, as, e.g., a general scheme of reorganisation in the regular or reserve forces, an increase in the armed strength, an improvement in the soldier's or sailor's pay, a large proposal for the rearmament of the troops or of forts, the necessity for increased accommodation at particular stations, some general change in clothing, etc. In the case of the Navy, policy turns chiefly on the programme of new construction.

"A general total having been arrived at between Ministers, the Department proceeds to draw up the Estimates in detail, and to submit each vote separately to the Treasury, with a covering letter, explaining more or less fully, as the circumstances may require, the reasons for any increase or decrease in the various items as compared with the sums taken in the previous year. The Estimate cannot be submitted to Parliament until Treasury sanction has been obtained, though such sanction may be given subject to the results of further consideration with regard to specific items (all of which are scrutinised by the Treasury as carefully as time permits).

"New charges of any importance are not to be inserted in the Estimates unless they have been previously sanctioned by the Treasury. It is very frequently the case that the Treasury is represented on Committees with which such new proposals commonly originate; and this Committee work is an important element in forming Treasury knowledge and control. The form of the Estimates is laid down by the Treasury, and no alteration of arrangement or classification can be made without Treasury sanction." 


\section{BRITISH FINANCIAL ADMINISTRATION}

Treasury Estimates Circular. The first step in the preparation of the Estimates consists in the issue by the Treasury, about October I of each year, of a circular letter addressed to the accounting officers of the several civil services, directing them to prepare and transmit to the Treasury the estimates for their services for the fiscal year beginning April I following. As these letters give in very compact and at the same time comprehensive form the conditions that must be observed in preparing these estimates, and the nature of the information that must be furnished, it has been deemed desirable to reproduce one of them in full. For this purpose

A Specific Instruction a selection has been made of the "Estimates Circular" for 1912-I913, which appears as Appendix No. I of the report of the Select Committee on Estimates (I912). ${ }^{1}$ The wording of this letter may vary slightly from year to year, but its general character and the nature of the instructions contained in it have now become practically standardized.

\section{ESTIMATES CIRCULAR I9I2-I9I3}

Treasury Chambers,

SIR :2d October, I9II.

The Lords Commissioners of His Majesty's Treasury command me to transmit to you the enclosed forms of estimates for the services to be administered by your Department during the year ending 3Ist March I9I 3.

One copy of each form, after insertion of the proper particulars, and with such changes as may be necessary, should be returned to the Treasury in due course. The figures of the past year should be carefully checked, and corrected where necessary. As much inconvenience is caused if the forms are not used, additional copies of

${ }^{1}$ Report of the Select Committee on Estimates (1912), Appendix No. I, pp. 134-136. 
them, as well as of this covering letter, will be furnished to you if needful.

Date of Rendering Estimates. Such of the estimates for 1912-1913 as require no special delay in their preparation should be sent to the Treasury on or before the Ist December I9II. Those estimates which, from peculiar circumstances, cannot be made up so soon, should be sent in as speedily after that date as possible. The latest date at which any estimate, or alteration of an estimate, can be received will be the $13^{\text {th }}$ January I9I2.

To enable the Estimates to be promptly issued, it is important that all questions which affect the details should, unless in exceptional cases, be settled before the Estimates themselves are sent in. Proposals for which treasury sanction is required should therefore be submitted well in advance of the time for sending in the Estimates. If in any case questions are still unavoidably outstanding, the Estimates should not on that account be delayed, but should be submitted to the Treasury in as complete a state as possible, upon the basis of existing rates and authorities, with the understanding that the items still under consideration are liable to alteration.

N. B. -In order that the Chancellor of the Exchequer may be in a position to ascertain the probable total of the Estimates at an early date, it is requested that in all cases where the delivery of the detailed estimate is likely to be delayed beyond I5th December I9II, the approximate total amount, so far as can be foreseen, may be communicated to the Treasury on or before that date.

Date of Statements of Expenditure, etc. All statements of actual expenditure on new buildings should be made up to the 3oth November 19II. The Estimates should not, however, be kept back on this account, but should be rendered, if necessary, with such statements in blank, leaving the omitted figures to follow later.

A like rule will govern any other statements of actual 
expenditure, or of actual receipts, or of time actually spent in particular services, etc., that may be admitted in the notes to the estimates.

The statements of Pensions granted and ceased should be made up to the 3 oth November I9II.

Necessity for Economy. My Lords direct me to remind you that, while it is essential, in order to avoid Supplementary Estimates, that no expense likely to be found necessary should be omitted in the first instance, yet the state of the public revenue makes it imperative to restrict the provision to such services and sums as are urgently required.

Explanation of Estimates. My Lords desire to impress upon Departments the fact that a sufficient explanation is necessary of the amount estimated for a duly authorised service even when it does not exceed the estimate of the preceding year. The habit of regarding each year's estimate as the starting point for the next is one against which special vigilance is needed in the case of services upon which the expenditure is in some degree discretionary, and My Lords think it necessary to warn Departments, especially those whose expenditure is of this character, that they must be prepared to subordinate such expenditure to the financial exigencies of each year.

Notification of Vacancies. My Lords request that Their attention may be drawn by a note upon the estimate to any office provided for in it which is vacant at the date of forwarding the estimate, and as to the future of which any question may be pending.

Form for Explanations. It is particularly requested that the explanations of the details of the estimate may in all cases be written upon the forms referred to in Regulation 3. The explanations should not be confined to mere statements that a larger or smaller amount is required, but should afford a justification of the whole 
amount inserted. Additional copies of the forms can be supplied if required.

Progress Reports. In any case where the estimate contains provisions for a special service which, though not permanent in character, extends over more than one year, My Lords request that the estimate may be accompanied by a report on such services showing-(a) the expenditure upon it to date as compared with the estimated total cost, (b) the progress made towards the completion of it; and stating whether the service is likely to be completed within the period previously anticipated, and at a cost not exceeding the amount sanctioned.

Estimate of Receipts in Stamps. I am to request that special attention may be given to the preparation of the estimate of receipts in stamps called for by Regulation I3.

Expenditure During the Current Year. I am to request that, in addition to the information required by Regulation 3, the figures of actual expenditure under each subhead may be given for the half-year to zoth September I9I I, with any comments upon them regarded as an indication of the probable expenditure in the current year.

Vote on Account. Before the commencement of the next financial year Parliament will be asked to grant a Vote on Account sufficient to provide for the requirements of each service for the normal period of the Session. In ordinary course the Treasury will fix the amount to be included for a particular service on the basis of the amounts which have been found sufficient in previous years. If there are any special circumstances which should be regarded in fixing the amount of your Vote on Account for next year, I am to request that you will draw attention to them in the letter submitting the estimate, indicating the amount which is likely to be required. 


\section{BRITISH FINANCIAL ADMINISTRATION}

The annexed regulations should be strictly observed in filling up the forms of estimates.

$$
\begin{aligned}
& \text { I am, etc., } \\
& \text { (Signed) C. Новноuse. }
\end{aligned}
$$

To the Accounting Officer.

Regulations to be Observed in Preparing the Civil Service and Revenue Departments Estimates.

I. Quotation of Statutes. In preparing the estimates the references to the chapters and sections of the statutes relating to the service provided for should be carefully revised and corrected according to the latest legislation, special care being taken to remove references to statutes which have been repealed or which are no longer applicable. Statutes governing the vote generally should be recited in the heading of it, and those relating to particular subheads should appear in the detail of those subheads.

2. Unsanctioned charges to be excluded. No charge for which due sanction has not been already obtained is to be inserted in an estimate. Any contemplated alteration, addition, or new provision, requiring Treasury approval, should be brought to Their Lordships' notice, if possible, in time for decision before the estimate is sent in. Where such a proposal cannot be submitted in advance of the estimate it should be dealt with in a separate explanatory letter.

3. Separate explanatory statements to be enclosed. The letter transmitting each estimate should also enclose statements written upon the sheets of which copies are sent herewith, and in the form of which a specimen is annexed, explaining and justifying seriatim the amounts provided in the estimate under each subhead of expenditure. The estimated amounts of receipts in cash or stamps should be similarly explained. 
4. Insertion does not convey sanction. Authority for a new or increased expense is not to be inferred from the fact of its having been, from any cause, printed in the estimates before the proper official sanction has been given.

5. Reference to Treasury Letters. If Treasury approval has been signified to any deviation from the provision made in the estimate for the preceding year, care should be taken to insert an accurate reference to the number and date of the Treasury letter conveying such approval.

6. Transfer of charges-(a) between subheads; (b) between votes. Whenever a transfer of charge from one subhead to another becomes necessary, the amount provided for the previous year for the service in question should be also transferred, so as to exhibit a proper comparison.

A like course should be followed if a charge be transferred, with previous Treasury consent, from one vote to another.

7. Gross charges to be provided for. Each estimate should provide for the gross amount of charges which will probably come in course of payment during the year under each subhead; and also for the gross receipt anticipated under the credit subhead, in cases where the system of appropriation in aid of the vote has been introduced.

8. Mode of providing for personal remunerations. All charges for the personal remuneration of the permanent or temporary staff of a department, including the pay of professional men engaged for special services, should be provided for in the subhead for "Salaries, etc.," unless some other arrangement has been specially sanctioned by the Treasury.

9. Extra remuneration of officers to be voted. In cases where remuneration, exceeding the sum of $£_{25} 5$ for the financial year, is received by any officer from public 
funds in addition to the ordinary emoluments of his office as provided in the estimate, a note must be appended, stating the amount of such remuneration, the service for which it is received, and the source from which it is provided. This rule is intended to apply to all extra remuneration, however casual or variable, and to any pension or compensation allowance in respect of Public Service, that an officer may receive, its object being to bring into one view the whole of his official emoluments from whatever source. Every officer is bound to report annually to the accounting officer of his department all the extra remuneration that he may have received in the year from any external source. The fact of an officer being provided with an official residence, fuel, or light, at the public expense, should also be recorded.

The mode of applying the foregoing regulation is more fully explained in Treasury Circular of 28th August 1897.

Io. Personal salaries. The estimate should be accompanied by a separate statement explaining with reference to treasury letters of approval, every "personal" salary or allowance included in the estimate.

II. Incidental expenses. The subhead for incidental expenses should, as a general rule, be confined to petty and casual charges, too insignificant to be provided for separately. Details of it should be furnished to the Treasury, although not necessarily for publication.

I2. Rates, taxes, insurance. Special attention should be called to any provision included in an estimate for rates, taxes, or insurance, with an explanation of the circumstances which are considered to make such provision necessary.

13. Receipts in cash and stamps to be estimated. Special care should be taken in calculating the Receipts appertaining to each estimate; and their nature should be stated, so as to show the probable yield of each principal 


\section{ESTIMATES: PREPARATION AND SUBMISSION}

source. The amounts that are likely to be collected in cash and in stamps should be stated separately. If any material increase or decrease be expected in either cash or stamp receipts the cause thereof should be explained to the Treasury, as prescribed by Regulation 3 .

I4. Responsibility of superior Departments. Departments charged with the duty of accounting for Parliamentary grants for Subordinate Departments or Services will be responsible for the observance of these regulations in the preparation and transmission of the several estimates of such Subordinate Departments and Services.

\section{ESTIMATES FORM: EXPLANATION OF INCREASES OR DECREASES}

Title of Vote.

\begin{tabular}{|c|c|c|}
\hline Subhead & $£$. & $\begin{array}{l}\text { Explanation of Increase or De- } \\
\text { crease in the Estimate for } \\
\text { I912-13 }\end{array}$ \\
\hline 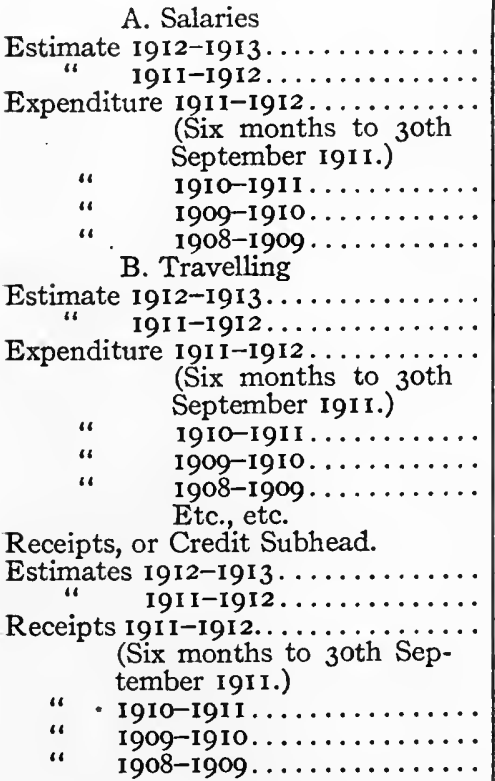 & & , \\
\hline
\end{tabular}


BRITISH FINANCIAL ADMINISTRATION

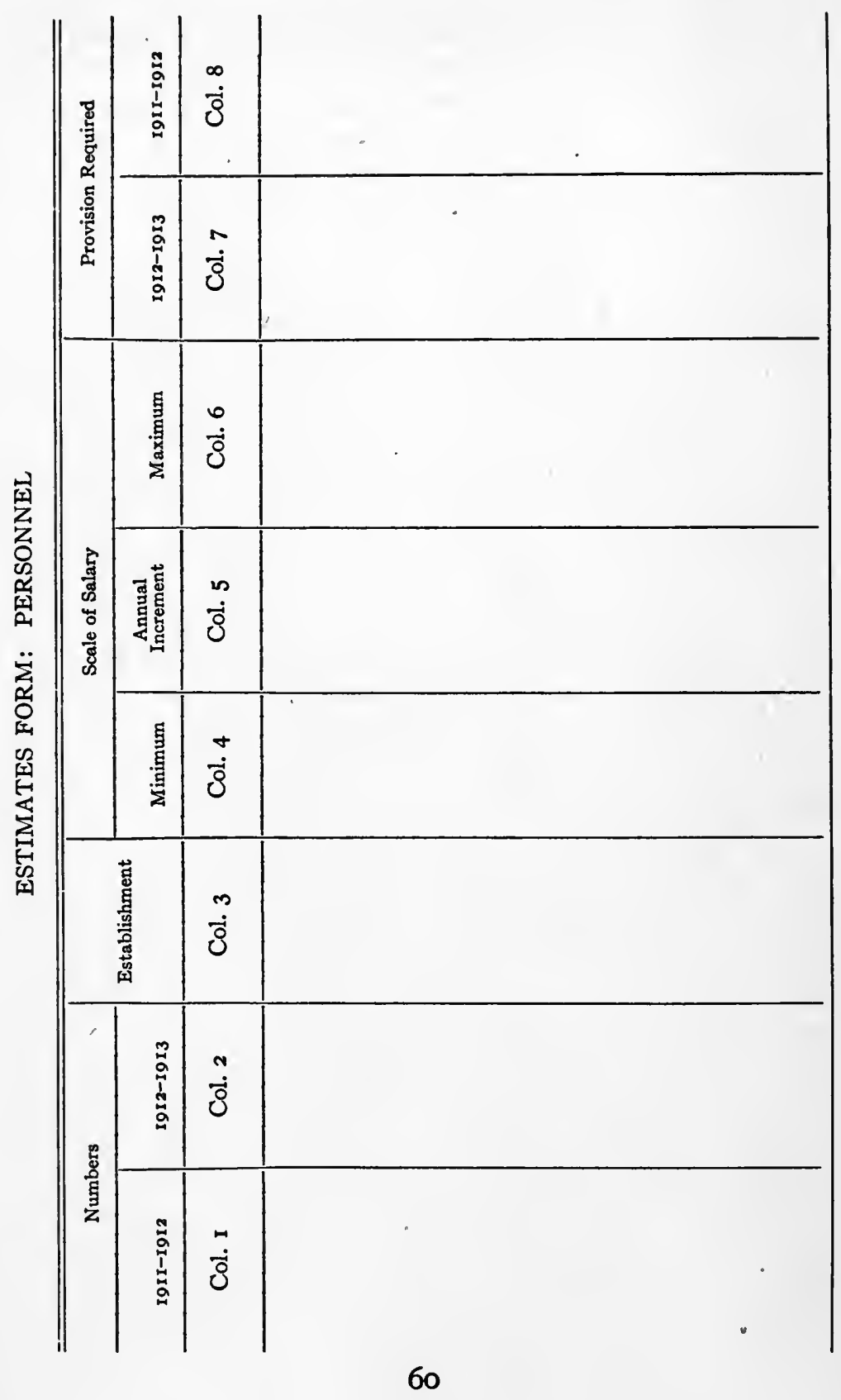


Estimates as Submitted by the Several Departments to the Treasury in Large Part but a Summation of Provisions Already Approved by the Treasury. There are certain features of this request for estimates that are of great interest, but which would probably escape notice unless attention were specially directed to them. The first and much the most important of these is that expressed in Regulation No. 2, that "no charge for which due sanction has not been already obtained is to be inserted in an estimate. Any contemplated alteration, addition, or new provision requiring Treasury approval, should be brought to their Lordships' notice, if possible, in time for decision before the estimate is sent in. When such a proposal cannot be submitted in advance of the estimate it should be dealt with in a separate explanatory letter.".

This rule bears upon an aspect of the budgetary practice of Great Britain which, so far as the commission is aware, has received little attention on this side of the water, yet it

Central Control over Changes constitutes a most vital feature of the whole system of Treasury control of the procedure in preparing and submitting the annual estimates. This feature is that the powers of the Treasury to control are exerted before, not after, the estimates for the several services are received by it. It is the duty of each service, as points arise which, in its opinion, will make desirable changes in existing financial provisions, to bring these points to the attention of the Treasury by letters and to secure Treasury sanction for such changes. Under this arrangement each change desired is taken up and considered upon its merits under circumstances which give ample time and opportunity for due consideration of the proposed change. This in fact is what actually takes place in the case of almost all changes of importance that the departments desire to have made. The result is that the estimates, when finally submitted by the departments, represent little more than the statement of proposals that have already been agreed upon between the various submitting departments and the 


\section{BRITISH FINANCIAL ADMINISTRATION}

Departmental Estimates a Summation of Prior Decisions
Fullness of Supplementary Data

Comparison of Expenditures
Treasury. Excepting in emergency, it should never be necessary to include items not approved in advance.

Sir Robert Chalmers, Permanent Secretary of the Treasury, has brought out this fundamental feature of the English estimate system in a very clear manner in his testimony before the Select Committee on Estimates (I9I2). After quoting the regulation he said: ${ }^{2}$

"The important thing which I want the Committee to realise from the two paragraphs of the Circular which I have read is that really the sending in of an Estimate is rather a summation of previous decisions on details than a sudden and initial demand for money. In all Estimates as they come in there are references to Treasury Authorities which have been given on nearly all specific cases. .. . What I want to make clear is that right through the year beginning with April, the preparation of the Estimate is going on in detail and the Estimate itself is more a summary than anything else so far as the ordinary Departments are concerned, whose work is not enlarged by sudden legislation at the end."

Comparative and Explanatory Data Required. A second point of importance is the fullness of the data that are required for comparative and explanatory purposes. As is elsewhere described, appropriations are made under certain general heads known technically as "votes." The total of each vote is subdivided under what are known as "subheads," which represent the heads under which all accounting of the money carried by each is to be rendered. Reference to the form entitled Explanation of Increase or Decrease shows that for each subhead there must be given, in addition to the amount estimated for the ensuing fiscal year: (I) The estimate for the current year; (2) actual expenditures for the first six months of the current year; and (3) expenditures for each

${ }^{2}$ Report of the Select Committee on Estimates (I9r2), p. 2. б́2 
of the three years preceding. If the service is one which receives any income from any source, corresponding data must be given regarding such income..

In respect to changes of personnel a detailed statement must be submitted, on a special form provided for the purpose, givList of Personnel ing under the heading "Establishment" a list of all positions to be provided for, and showing for each position: (I) The number of employees for the current year; (2) the number desired for the ensuing year; (3) the scale of salary to be paid, showing the minimum salary carried by the position, the annual increment provided for length of service and the maximum salary that can be paid; (4) the total provision made for the payment of salaries of persons in each position; and (5) the total sum that will be required for making such payment in the ensuing year.

In accordance with other regulations, details must be given regarding the items of incidental expenses and other subheads. We have already noted that for the most part all changes in Details of Expenses proposed estimates over current provision have previously been brought to the attention and received the approval of the Treasury. The regulations require that reference shall be made to all letters of the Treasury in which such changes have been authorized.

In connection with the securing of data for comparative purposes it is of interest to note that these data are as far as possible inserted by the Treasury in the forms before they are sent to the departments. Thus, for example, in the form upon which the details regarding personnel are to be given, all of the eight columns except the two calling for the estimates proper for the year to which the estimates relate are filled in by the Treasury before the form is sent out. All that the departments hav to do is to verify these figures and fill in the two columns remaining. This procedure insures that the Treasury will get the information in precisely the form and detail desired by it. What is of equal importance, it expedites enormously the subsequent work of scrutinizing the

Comparative Data Prepared by the Treasury 


\section{BRITISH FINANCIAL ADMINISTRATION}

Estimates

Filled In by

Department

returns and getting them into shape for transmission to Parliament. At best the Treasury has thrown upon it a great volume of work that has to be done with the greatest expedition possible. It is evident that this procedure, taken in connection with the fact that almost all changes of importance have already been considered and passed upon, facilitates this work greatly.

The figures filled in for the current year represent the aggregation of the original estimates and any supplemental estimates that may have been granted. It should be noted, however, that it is possible for further grants to be made for the current year, since the final supplementary votes of one financial year are not generally taken until after the estimates for the following year have been presented. This is unfortunate, but apparently unavoidable.

Finally, it may be noted that it is the custom for each service to send in the estimates with a general covering letter in which attention is directed to any matter of especial importance and particularly to those changes which for any reason have not already received the Treasury sanction.

Estimates to Be Justified, Though No Increase Is Requested. A minor point, and yet one of no little importance, is that covered by the section of the "Estimates Circular" which provides that "My Lords desire to impress upon Departments the fact that a sufficient explanation is necessary of the amount estimated for a duly authorized service even when it does not exceed the estimate of the preceding year. The habit of regarding each year's estimate as the starting point for the next is one against which special vigilance is needed in the case of services upon which the expenditure is in some degree discretionary." It is one thing to keep down addi-

Responsibility Placed on Executive tional expense and quite another to effect reductions in authorized expenditures in the past which are in excess of present real needs. The requirement quoted, in addition to being a general appeal for economy, has for its purpose the laying 
of the basis for the Treasury questioning any item, whether or not it exceeds the provision for the current year. It is the duty of the Treasury to familiarize itself as far as possible with the needs of the several departments and to effect reductions as well as to check increases. It goes without saying, however, that the effectiveness of its action in respect to the first is much less than it is as regards the second requirement.

Preparation of Estimates Within the Departments. Only a few words need be said regarding the methods followed by the departments in preparing their estimates. Their task has been much simplified by the Treasury having filled in much of the comparative data before the forms are sent to them, and still more so by the fact that almost all the contemplated changes over existing provisions have already been raised Methods Employed with the Treasury and received a settlement. The nature of the work to be done by them is described in the "Memorandum on the Annual Estimates" which is appended to the report of the Select Committee on National Expenditures (I902), in the following terms: ${ }^{1}$

"The work of preparation of the Estimate within the Department itself varies in its character according to the scope of the Department and of its Vote. In the case of small Departments, where the whole establishment is congregated under one roof, the accounting officer, assisted by the officer in charge of the accounts, has usually all the materials at hand. The establishment books of the department show the salary of every officer and the date at which his next increment accrues, and records are kept of any decisions involving changes of the establishment. It is thus possible to calculate with exactitude the amount which will be required for personal remuneration, subject of course to any changes which may arise

${ }^{1}$ Report of Select Committee on National Expenditure (1902), p. I92.

Varies in Different Departments 


\section{BRITISH FINANCIAL ADMINISTRATION}

through death or other unexpected causes. For the other Subheads of the Vote, comprising the charges incidental to the work of the Department, the accounting officer is guided by past expenditure, as well as by his knowledge of any changes which have been effected or may be impending in the Department's business, and any doubtful points are settled in consultation with the officers whose work they specially concern.

"In the large Departments many of the Subheads of the Vote can be estimated in the same way by the account-

Subsidiary Estimates

Comparison with Practice Here ing officer from his general knowledge and experience. But where there are larger branches of the Department carrying on their work away from its headquarters, it may be necessary to obtain subsidiary estimates from the heads of those branches of their portion of the expenditure. In the Inland Revenue Department, for instance, reference is made to the Controller of Stamps and Stores, the Chief Inspector of Taxes, the Government Chemist and the local Collectors, before fixing the provision for the Subheads with which they are concerned. When the necessary particulars have been obtained they are collated by the accounting officer and the estimate as a whole is reviewed by him under the direction of the head of the department; and the demands of individual branches may have to be reduced before the Estimate is forwarded to the Treasury, either on their own merits, or on a consideration of the total of the Estimate and the comparative strength of other claims."

The process of preparing the estimates in the departments is thus not dissimilar from that obtaining in the United States, with this important exception: In Great Britain there is one important officer of high rank, and with real authority and responsibility, whose duty it is not only to prepare the estimates, but to use his utmost efforts to see that they do not call for expenditures not justified by the real needs of the 
service. In the United States the responsibility falls upon the head of the service. As this official is one who usually changes with each administration, who thus has not grown up with the service and who has no intimate and detailed knowledge of the requirements, his responsibility is of the most general character. Certainly he is not in a position to exercise as intelligent direction and control over the details of the estimate as is the permanent acounting officer under the British system.

Examination of the Estimates by the Treasury. Having reached the Treasury, the next step in getting the estimates into shape is their critical examination and revision by that authority. The manner in which this work is performed is excellently described in the memorandum from which we have just quoted. ${ }^{1}$

"When the Estimates for the Civil Services and Revenue Departments reach the Treasury they are examined by the Estimate Clerk, assisted by one of the junior clerks. The first business of the juniors is to go through all the figures of the Estimate, noting in the margin the by Estimate - increase or decrease on every item which shows a difference from the previous year, either as regards number of staff or amount of provision. Any alteration which the Department proposes to make in the body of its Estimate, in the particulars represented by Columns 3 to 6 (Establishment and scale of salary) of the form already described, is at once apparent because the existing state of things is represented by the printed matter of the form. All variations of this kind, as well as all changes in the amount of the monetary provision which are not the result of the automatic operation of progressive scales of pay, are then compared with the record of Treasury sanc-

\footnotetext{
${ }^{1}$ Report of the Select Committee on National Expenditure, 1902, p. 192.
} 


\section{BRITISH FINANCIAL ADMINISTRATION}

tions relating to the Estimate which has been given since the previous year's Estimate was framed. For the purpose of this record, the several divisions of the Treasury have from time to time referred to the Estimate Clerk any decisions of the Board of Treasury which would entail alterations in any estimate. Every change which the estimate shows should be either covered by a sanction thus recorded or be otherwise satisfactorily accounted for in the Department's explanations.

"The Estimate Clerk examines the estimate as regards any discrepancy on the above points, and also considers the necessity for the monetary provision in the light of past expenditure and of the explanations. Each separate subhead is regarded, and also the estimate as a whole. It it not sufficient merely to examine the subheads piecemeal

Conference with

Department Officers for this reason:-The ideal of a scrupulous accounting officer is apt to be to provide on each individual subhead enough money for its probable requirements with a small margin for contingencies. In an estimate which has a large number of subheads the effect of providing for each one thus fully may be to take an excessive amount for the vote as a whole, even though no particular subhead could be regarded as extravagant. In order to guard against this tendency, the Treasury has to pay regard to the total vote, so as to ensure that proper allowance is made for the compensating effect of surpluses and deficiencies in the various subheads. If the Estimate Clerk is in doubt as to the effect proposed to be given to any Treasury sanction he refers the estimate to the Principal Clerk in charge of the Treasury Division which deals with the Department concerned. That officer is also consulted as to any new proposal referred to in the estimate, and even in the absence of such special reason, he has usually the opportunity to advise upon any important estimate relating to the departments with which he deals. 
"The estimate then goes before the Financial Secretary, who directs the action to be taken upon any of the points submitted to him by his subordinates. $\mathrm{He}$ also considers the estimate in its general bearings, by his knowledge of the affairs of the Department, of Parliamentary opinion upon the services for which this Estimate provides, and of the financial circumstances of the time. He decides whether the estimate shall be approved as submitted, or what criticisms and suggestions for its amendment shall be offered to the Department. In the latter event, subsequent correspondence may elicit explanations from the Department which will justify the Treasury in passing the Estimate, or alterations may be agreed between the Departments. Should agreement not be reached, it would be open to the Treasury, in the last resort, in the exercise of its responsibility, to present the Estimate to Parliament in the shape approved by the Treasury."

Transmission of the Estimates to the House of Commons. The fiscal year, it will be remembered, begins April r. The "Estimates Circular," calling for estimates from the several civil departments, is issued about October I of the year preceding. It directs that when possible the departments should make their returns by December I. Inasmuch as there are Date of
Submission certain estimates which cannot be framed so far in advance of the financial year to which they relate, a further date is mentioned upon which these estimates should be in hand. This latter date varies from year to year, according to the period at which Parliament is expected to assemble, but usually is some date early in January. In practice the bulk of the estimates reach the Treasury between December I and the date so fixed. The middle of January may therefore be taken as the date upon which all estimates must be in the hands of the Treasury. As has been pointed out, the Treasury has already done the bulk of its work in passing upon applica-

Review by Financial Secretary 
tions for changes presented to it one by one by the several departments. The work of further studying the estimates, deciding points still open, and assembling the material, thus proceeds rapidly. Parliament usually convenes some time in February. Shortly after it assembles, the estimates are in form and are laid before it. The estimates for I9I4-I9I5 bear the date of March 2, I9I4.

Supplementary Estimates. As it is impossible for the departments in preparing their estimates to foresee all continConditions gencies, and as conditions may easily arise calling for the under Which They Are Made expenditure of funds not provided for in the regular estimates, the departments from time to time send supplementary estimates to the Treasury, which, if approved by that authority, are laid before Parliament. These supplementary estimates are apt to represent new demands rather than additions to demands already contained in the regular estimates, for all minor deficiencies under one head can be met by transfers of money from other heads under a system that will be presently described. Thus supplementary estimates are resorted to only when the amount asked for is important and exceeds the total resources of the department.

Though supplementary estimates may be submitted at any time, it is usual for the Treasury to submit them to the House of Commons in two batches: One in July prior to the adjournment of Parliament for the summer and prior to the

Usually Submitted in Two Batches passage of the annual appropriation act, and the other in February just prior to the close of the fiscal year. These are known as the summer and the February supplementaries. Both, it will be noted, are submitted during the fiscal year to which they relate. If the regular estimates have not been considered prior to the submission of the summer supplementaries, the two are considered together. It should be observed that in the annual estimates, when grants for the current year are given, for comparative purposes, they include the sums granted in pursuance of the summer supplementaries, 


\section{ESTIMATES: PREPARATION AND SUBMISSION}

but not those called for by the February supplementaries. Every effort, however, is made to have the regular or summer supplementaries cover all expenditures, with the result that the February supplementaries are usually small in amount and relate to but a few votes. 


\section{CHAPTER IV}

\section{THE ESTIMATES: CHARACTER AND FORM}

Classification of Estimates; Appropriation Heads: "Votes"; Appropriation Subheads; Supporting Details; Order of Presentation of Data; General Summaries and Analyses.

We have now reached the position where the estimates have been received, compiled, and laid before Parliament by the Chancellor of the Exchequer and the heads of the War and Navy departments. In our analysis of the problem of

"The Estimates" only a Part of a Budget administering the public finances of a nation we have pointed out that the summaries of estimated expenditures commonly called "The Estimates" proper constitute, or should be made to constitute, but one part of a financial plan presented in a document known as "The Budget"- the function of "The Budget" being to bring such estimates into comparison with past expenditures, current appropriations, and the resources available with which to meet the expenditures proposed. If the estimates are to be of a character such that their purport can be readily seen, it is imperative that they be classified, summarized, and compared with past expenditures and appropriations in such a way that the appropriating authority and the general public can readily determine the extent to which these estimates represent a change in policy in respect to the expenditure of funds, the objects for which increased expenditure is proposed, and those for which a reduction of expenditures is called for.

This subject of the form in which the estimates should be submitted and the summaries and comparative tables that should accompany them, in order that their significance may be seen, is one of great importance. The commission has, 
therefore, in the pages that immediately follow, sought to give as full a description of the character of the English estimates as they come before Parliament as it is possible to do without actually reproducing the estimates themselves in full.

Classification of Estimates. The whole character of the estimates depends on the manner in which the sums asked for Expenditures by are classified and totaled. The first classification is that between the four groups of services, which are designated:

\section{Army \\ 2. Navy \\ 3. Civil Services \\ 4. Revenue Departments}

The Army and Navy estimates embrace the estimates not only for the military and naval establishments, but for the War Office and the Admiralty, by which these establishments are administered. The result of this primary classification is Army and Navy to distinguish clearly between estimates and expenditures for military and naval purposes and those for civil purposes. The distinction between the civil services and the revenue departments is also one of great value. In this connection it should be noted that the Treasury quite properly is not treated as one of the revenue departments, but as one of the civil services.

As the Army and Navy represent unifunctional services, no further classification of estimates and expenditures is made in respect to them except that represented by the individual "vote," to which attention will shortly be directed. The civil Civil and Revenue services and revenue departments are, however, further classiServices fied, the former into seven and the latter into three groups, as follows:

Civil Services:

I. Public Works and Buildings

2. Salaries and Expenses of Civil Departments 
3. Law and Justice

4. Education, Science and Art

5. Foreign and Colonial Services

6. Non-effective and Miscellaneous Services

7. Old-age Pensions, Labor Exchanges, Insurance, etc.

Revenue Departments:

I. Customs and Excise

2. Inland Revenue

3. Post Office

Groupings Historical, not Logical

These groupings are historical rather than logical. Whether or not the classification may be considered as one which in the main is satisfactory, it clearly distinguishes between such important groups of expenditure as those for the administrative services proper (Class 2), those for judicial purposes (Class 3), those for public works (Class I), etc. Class 2 includes expenditures for Parliament as well as those for the executive departments proper, but the two are clearly distinguished by separate votes within the class. In all cases the departments handling the kind of business to which a class relates are included in that class, and not in the class of salaries and expenses of civil departments. This is as it should be, since it brings together all expenditures relative to a particular category of work.

Appropriation Heads: "Votes." The next subdivision within these classes consists of the heads under which appro-

Character and Number of "Votes"

priations are actually made, or, as they are technically called, "votes"-or a subdivision on which a separate vote will be asked when the estimates are being considered in committee of the whole on supply. Of such votes there are 15 in the Army estimates, 15 in the Navy estimates, 120 in the Civil Service estimates and 3 in the Revenue Department estimates, a total of 153 heads under which appropriations are made. As few matters in connection with the grant of funds for the 
conduct of Government operations are of greater importance than the particularity with which appropriations are made, it has been thought desirable to reproduce these 153 appropriations heads in full in the order in which they appear in the estimates. They are as follows:

\section{ARMY}

I. Pay, etc., of the Army

2. Medical Establishments: Pay, etc.

3. Special Reserve

4. Territorial Forces

5. Establishments for Military Education

6. Quartering, Transport and Remount

7. Supplies and Clothing.

8. Ordnance Department Establishments and General Stores

9. Armament, Engineer and Aviation Stores

ro. Works and Buildings

II. Miscellaneous Effective Services

I2. War Office

\section{Non-effective Services}

I3. Non-effective Charges for Officers, etc.

14. Non-effective Charges for Men, etc.

15. Civil Superannuation, Compensation and Gratuities

\section{NAVY}

I. Wages of Officers, Seamen and Boys, Coast Guards and Royal Marines

2. Victualing and Clothing for the Navy

3. Medical Establishments and Services

4. Civilians Employed on Fleet Services

5. Educational Services

6. Scientific Services . 
7. Royal Naval Reserves

8. Shipbuilding, Repairs, Maintenance, etc.

9. Naval Armament

10. Works, Buildings, and Repairs at Home and Abroad

II. Miscellaneous Effective Services

12. Admiralty Office

I3. Half Pay and Retired Pay

Non-effective Services

I4. Naval and Marine Pensions, Gratuities, and Compensation Allowances

15. Civil Superannuation, Compensation Allowances and Gratuities

\section{CIVIL SERVICES}

Class I. Public Works and Buildings

I. Royal Palaces

2. Osborne

3. Royal Parks and Pleasure Grounds

4. House of Parliament Buildings

5. Miscellaneous Legal Buildings, Great Britain

6. Art and Science Buildings, Great Britain

7. Diplomatic and Consular Buildings

8. Revenue Buildings

9. Labor Exchange Buildings, Great Britain

Io. Public Buildings, Great Britain

I I. Surveys of the United Kingdom

12. Harbors under the Board of Trade

13. Peterhead Harbor

14. Rates on Government Property

I5. Public Works and Buildings, Ireland

16. Railways, Ireland

17. The Palace of Peace, The Hague 
Class II. Salaries and Expenses of Civil Departments

\section{United Kingdom and England}

I. House of Lords Offices

2. House of Commons

3. Treasury and Subordinate Departments

4. Home Office

5. Foreign Office

6. Colonial Office

7. Privy Council Office

8. Board of Trade

9. Mercantile Marine Services

Io. Bankruptcy Department of the Board of Trade

II. Board of Agriculture and Fisheries

12. Charity Commission

I3. Chemist, Government

14. Civil Service Commission

15. Exchequer and Audit Department

16. Friendly Societies Registry

17. Local Government Board

I8. Lunacy Commission

19. Mint, including Coinage

20. National Debt Office

21. Public Record Office

22. Public Works Loan Commission

23. Registrar General's Office

24. Stationery and Printing, Stationery Office

25. Wood, Forest, etc., Office of

26. Works and Public Buildings, Office of

27. Secret Service

\section{Scotland}

28. Secretary for Scotland, Office of 29. Board of Agriculture 
30. Fishery Board

3. Lunacy Commission and General Board of Control

32. Registrar General's Office

33. Local Government Board

\section{Ireland}

34. Lord Lieutenant's Household

35. Chief Secretary's Offices and Subordinate Departments

36. Department of Agriculture and Technical Instruction

37. Charitable Donations and Bequests Office

38. Congested Districts Board

39. Local Government Board

40. Public Record Office

4I. Public Works Office

42. Registrar General's Office

43. Valuation and Boundary Survey

\section{Class III. Law and Justice \\ United Kingdom and England}

I. Law Charges

2. Miscellaneous Legal Expenses

3. Supreme Court of Judicature and Court of Criminal Appeal

4. Land Registry

5. Public Trustee

6. County Courts

7. Police, England and Wales

8. Prisons, England and the Colonies

9. Reformatory and Industrial Schools, Great Britain

Io. Criminal Lunatic Asylums, England 


\section{Scotland}

I I. Law Charges and Courts of Law

I2. Scottish Land Court

I3. Register House, Edinburgh

I4. Prisons

\section{Ireland}

I5. Law Charges and Criminal Prosecutions

I6. Supreme Court of Judicature and other Legal Departments

I7. Land Commission

I8. County Court, Offices, etc.

19. Dublin Metropolitan Police

20. Royal Irish Constabulary

21. Prisons

22. Reformatory and Industrial Schools

23. Dundrem Criminal Lunatic Asylum

Class IV. Education, Science and Art

United Kingdom and England

I. 'Board of Education

2. British Museum

3. National Gallery

4. National Portrait Gallery

5. Wallace Collection

6. Stafford House

7. Scientific Investigation, etc.

8. Universities and Colleges, Great Britain, and Intermediate Education, Wales

\section{Scotland}

9. Public Education

Io. National Galleries 


\section{Ireland}

II. Public Education

I2. Endowed Schools Commissioners

I3. National Gallery

I4. Science and Art

I5. Universities and Colleges, Ireland

Class V. Foreign and Colonial Services

I. Diplomatic and Consular Services

2. Colonial Services

3. Telegraph Subsidies and Pacific Cable

4. Persian Loan

Class VI. Non-effective and Miscellaneous Services

I. Superannuation and Retired Allowances

2. Miscellaneous Expenses

3. Hospitals and Charities, Ireland

4. Temporary Commissions

5. Repayment to the Local Loan Funds

6. Ireland Development Grant

7. International Exhibitions

8. Repayment to the Civil Contingencies Fund

Class VII. Old-Age Pensions, Labor Exchanges, InsurANCE, ETC.

I. Old-Age Pensions

2. National Health Insurance, Joint Committees

3. National Health Insurance Commission, England

4. National Health Insurance Commission, Wales

5. National Health Insurance Commission, Scotland

6. National Health Insurance Commission, Ireland

7. Labor Exchanges and Unemployment Insurance

8. National Insurance Audit Department

9. Treatment of Tuberculosis (Special Grants)

80 


\section{ESTIMATES: CHARACTER AND FORM}

IO. Highland and Inland (Medical Service)

I I. Friendly Societies' Deficiency

12. Expenses under the Unemployed Workmen's Act (1905).

An examination of this list of appropriation heads brings out a number of facts of importance. It shows, in the first Facts of Importance place, that the principle of classification employed is that of services or organization units, the result being that the estimates and appropriations show at a glance the amount of money required for operating each distinct branch of the government service. In the second place it shows that the policy is pursued of having a single appropriation for each distinct branch of the government service. Another feature of interest is the policy of distinguishing, as far as is practicable, between appropriations for the support of services for the United Kingdom and England and those for Scotland and Ireland. Finally, a very interesting distinction is made between appropriations for effective and so-called "non-effective" services, the latter including such items as pensions, gratuities, retired pay, etc.

In making use of the estimates in order to determine the cost of particular services it is important to note that the amounts appropriated for such services do not include expenditures for quarters and building supplies, nor for stationery, printing, and other office supplies, these being provided for in the appropriations for the Office of Works and Public Buildings and the Stationery Office. It is, however, an easy matter to get at the expenditures of each service for these purposes, since the accounts of these two offices show the cost of the services or materials supplied to each service. Moreover, in the report of the Comptroller and Auditor General on appropriation accounts is a table giving the cost of each service that is borne by other services, so that the total cost of each service can be seen. ${ }^{1}$

\footnotetext{
1 See p. 25 I.
} 


\section{BRITISH FINANCIAL ADMINISTRATION}

Distinction Between a "Vote" and a "Subhead"

Power of Transfer

Appropriation Subheads. The next step in the separation of items going to make up the total of expenditures, the authorization which is requested, is that of allocating to certain specified subheads the total amount asked for under each appropriation head. The amounts so assigned to subheads differ from the total assigned to appropriation heads in this important respect: The sums carried by the appropriation heads are true appropriations in that, with the exception of the Army and Navy votes, they cannot be exceeded unless special authority therefor is secured from Parliament; the sums allocated to subheads, on the other hand, are in the nature of a provisional allotment of the sums voted, since amounts carried under one head may be transferred to another head if the sanction of the Treasury to such action is obtained. However, in granting this freedom to the Executive to use surpluses under one subhead for the purpose of meeting deficits under another, Parliament requires a rigid accounting of the manner in which this discretion is used. Technically these subheads are denominated as "Subheads under which votes must be accounted for to Parliament." This means that, though there is a single appropriation for a service, the accounts must be kept by subheads, in which of course will appear all transfers effected. It is furthermore the duty of the Comptroller and Auditor General, in rendering his report on appropriation accounts, to frame it so as to show audited expenditures according to these subheads, and specially to call attention to all cases where in his opinion improper use has been made of this power of virement, as the expression is.

By way of exception, this power to make transfers from one subhead to another is, in the case of the Army and Navy votes, extended to the votes themselves. The latter thus in effect have practically the same appropriation status as subheads. This exception has been made in order to give to these two great departments a greater facility to meet emergencies as they arise. 
It is hardly' necessary for us to point out the importance of this distinction between appropriation heads, or votes, and subheads. It introduces an elasticity in the utilization of the funds granted that would be lacking were the sums assigned to the subheads treated as definite appropriations. Notwithstanding these manifest advantages from an administrative standpoint, the system is one which has not passed unchallenged. In a paper submitted to the Select Committee on National Expenditure of $1902,{ }^{1}$ Mr. T. Gibson Bowles vigorously attacked the system of allowing transfers between Army and Navy votes. Though his criticism is directed specially to this practice, much of his reasoning applies equally to the practice of permitting transfers between subheads. The importance of the principle here involved warrants our reproduction of the more important passages of Mr. Bowles' paper. He says :

"Under a usual clause in the Appropriation Acts since 1862, the Treasury is empowered, in the case of the Army and Navy Votes, to authorise the departments to apply any savings that may be made on one Vote towards any other Vote of the same department in which an excess of expenditure has occurred. This system of applying the surplus of one Vote to meet the deficiency of another palpably amounts to a defeat of the appropriation made by the Act, inasmuch as it diverts to one Vote the money appropriated by the Act to another. It as palpably tends to the presentation of incorrect estimates. It is also calculated to prevent the due surrender of unexpended balances, by allowing of their application to other purposes; and it tends to the allowance of delay in rendering the year's accounts and the postponement of bringing into account all such excesses as are not capable of being met out of surpluses on the other Votes, as well as

${ }^{1}$ Report of Select Committee on National Expenditure (1902), Appendix No. 8, p. 213 . 


\section{BRITISH FINANCIAL ADMINISTRATION}

Overlooks the Principle of the Executive Accountability

to the postponement of actual payments properly chargeable to the year. And it must encourage the department to regard the total sum voted in respect of its services as one huge pooled fund into which it may dip at its own discretion, and irrespective of the specific appropriation, for any extra expenditure whatever, provided the total fund be not exceeded. It would seem that the Treasury has forgotten that an excess is a financial offence, and has come to a practice of authorising this diversion from one Vote to another of the sums granted, almost as a matter of course; and although the subsequent sanction of Parliament to the excess of expenditure over the authorised expenditure has to be obtained in such cases that will seem a very insufficient safeguard to those who know how ready Parliament is to sanction the accomplished. fact. . . The tendency bred by the easy diversion of savings to excesses must be to encourage incorrect estimates, and to suggest a general overestimate in order that there may be in the general pooled fund of the department as large a balance as may be to move about from one Vote to another. The diversions of appropriation thus affected by Treasury allowance are, it is true, submitted to the House of Commons for its sanction, but this is done usually at the very close of the next year's session, the sanction is treated as a mere matter of formality, is hurriedly and summarily debated, and is asked for in one resolution for each of the two services, covering in each instance all the diversions made, a method which affords no adequate opportunity of putting any sufficient check upon a growing and dangerous diversion of public funds from their allotted purposes. The system of diversion of the moneys voted for, and appropriated solely to one purpose, to other and different purposes is one which seems for the reasons above cited to demand jealous. watch by the Treasury of Departments, and by the Public Accounts Committee of the Treasury." 
To the commission it would appear that, though all the dangers mentioned by the author of the criticism above reproduced are undoubtedly present, indeed are inherent in the system, much can be said on the other side. In the first place, if a department has not the faculty of making use of any savings that it may make out of the funds allotted to a parAnother View ticular purpose, but must surrender all such surpluses to the General Treasury, all, or at least a very strong, incentive to economy is removed. Two of the authors of the present report were at one time heads of departments in the government of Porto Rico, where this faculty of making transfers from one appropriation subhead to another existed. They can both testify that this possibility of making use of realized surpluses caused them to make every possible effort to squeeze out savings on this and that subhead in order to secure funds to supplement appropriations which were inadequate for the purposes for which they were granted. One of the authors has also been intimately connected with the executive department of the Federral Government at Washington, where this power of utilizing surpluses did not obtain. He can testify no less emphatically that there the whole spirit was directly the contrary to that which prevailed in Porto Rico. Administrators felt that it was a calamity if any unexpended balance American Practice Cited in Answer to Criticism of an appropriation remained at the end of the year for surrender to the Treasury. As the end of the year approached the condition of appropriation balances was carefully studied with the deliberate purpose of seeing how all the money available could be used. This was but human nature. Any money that had to be returned to the Treasury was a loss to the service for which it was originally appropriated. It is thus a mistake to assume that if the power of making transfers is withheld the Treasury will profit to any appreciable extent by repayment to it of unexpended balances of appropriations.

Against the argument that the power to make transfers leads the departments to estimate under certain heads for larger sums than will be required in order that a surplus may 


\section{BRITISH FINANCIAL ADMINISTRATION}

be obtained that will be available for transfer to other heads may be placed the argument that if such transfers are not permitted the departments will be forced to estimate on the safe sicle for all items of appropriation. Thus Sir Edward Hamilton, in a paper filed with the Select Committee on National Expenditure (1902), said: ${ }^{1}$

"In the second place, the absence of the power of vire-

Sir Edward Hamilton's View
Elasticity Does not Produce Control ment would not conduce to good Administration. To guard against the risk of an underestimate on each separate Vote and of the consequent necessity for making a supplementary application to Parliament, the Naval and Military Departments would naturally feel bound to estimate each Vote more liberally than they do now, with the result that their aggregate spending power would be augmented. It not infrequently happens that, in the course of the year, an item of expenditure is sanctioned by the Treasury conditionally, that is, on condition that, if an excess is caused on the Vote, it shall be met out of savings on other Votes; and the result is that savings are effected which might not otherwise be effected. I submit, therefore, that the present system decidedly makes for economy and prevents wasteful expenditure."

Finally it should be repeated that in the provisions that the transfers can take place only upon the authority of the Treasury; that the accounts must be so kept and rendered as to show clearly all transfers; that these transfers must be reported to the House of Commons and that those transfers which do not appear to have been properly justified must be specially commented upon by the Comptroller and Auditor General in his report and, if need be, be further examined by the Public Accounts Committee, all possible safeguards would seem to have been thrown around the abuse of the power thus conferred upon the expending authorities.

${ }^{1}$ Report of the Select Committee on National Expenditure (1902), p. 225. 
Turning now to the character of the subheads thus provided for, it will be found that the principle followed is that of distinguishing: ( I) Between the subordinate services included under the more comprehensive organization unit for which the appropriation is made; and (2) between the objects of by Objects expenditure. As regards the second of these divisions, namely, that concerning the objects of expenditure, the important distinctions are those between expenditures for salaries and wages, for traveling and incidental expenses, and for other special categories of expenses. The specific subheads under which an accounting must be made, however, vary with the different services according to their character. The extent to which the character of the service renders it feasible to specify expenditures in detail seems to have an important bearing on the number and variety of subheads which are given under the different votes. There is no distinction, however, in principle, and an examination of any one of the important votes will show the general character of subhead classification. The following statement of the manner in which the vote for the Home Office is assigned to subheads, reproduced textually from the estimates for I9I4-I9I5, furnishes a typical illustration of the manner in which this problem of subheads is handled: 


\section{BRITISH FINANCIAL ADMINISTRATION}

\section{Home OfFice}

I. Estimate of the Amount required in the year ending 3ist March, I9I 5, to pay the salaries and expenses of the office of His Majesty's Secretary of State for the Home Department and subordinate offices.

Two Hundred and Sixty-eight Thousand and Six Hundred Pounds

II. Sub-heads under which this vote will be accounted for by the Home Office.

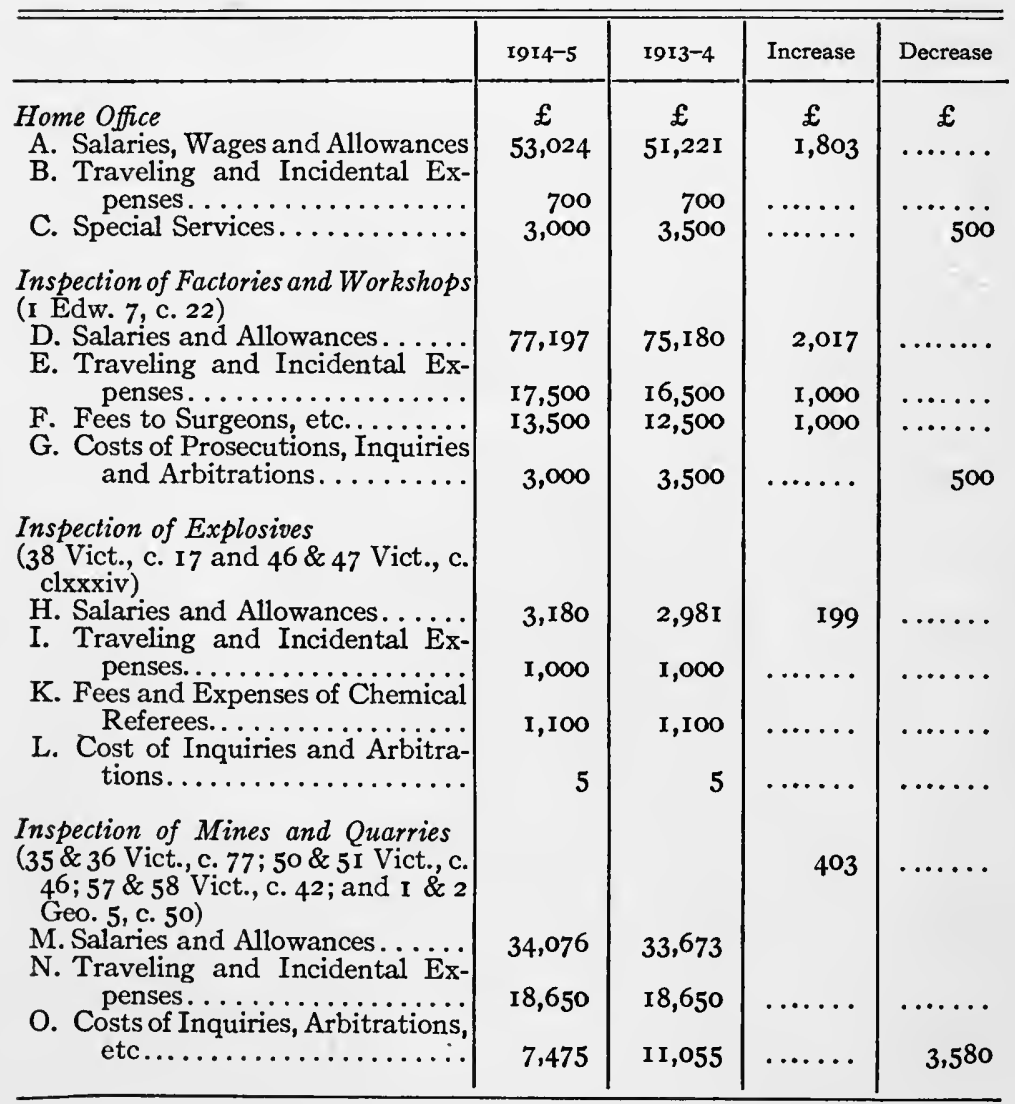




\begin{tabular}{|c|}
\hline 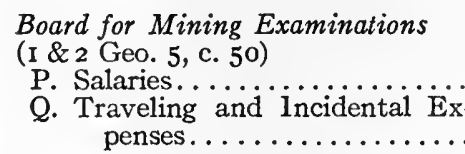 \\
\hline
\end{tabular}

Inspection under Cruelty to Animals Act

(39\& 40 Vict., c. 77)

R. Salaries.......

S. Traveling and incidental Expenses................

Inebriates Acts, 1879 to 1898

(42 \& 43 Vict., c. 19; 51 \& 52 Vict., c. 19; 61 \& 62 Vict., c. 60)

T. Salaries. . . . . . . . . . .

U. Traveling and Incidental Ex-

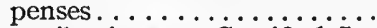

V. Contributions to Certified Inebriate Reformatories......

W. Maintenance of Criminal Lunatics transferred from Certified Inebriate Reformatories to Local Asylums.

Workmen's Compensation Act, Igo6 (6 Edw. 7, c. 58 )

$\mathrm{X}$. Fees and Expenses for Medical Referees, etc............

Aliens Act, 1005

(5 Edw. 7, c. I3)

Y. Salaries, Fees and Allowances to Officers. . . . . ..........

Z. Traveling and Incidental Ex-

AA. Immigration Boards: $\not$ Fees of Members and Clerks.......

BB. Expenses of Expulsion Orders.

Home Office Industrial Museum

CC. Expenses..............

Role of the Baronetage

DD. Expenses.

Gross Total.

Deduct

EE. Appropriations in Aid.

Net Total.

Net Increase $£_{987}$

\begin{tabular}{|c|c|c|c|}
\hline I9I $4-5$ & I913-4 & Increase & Decrease \\
\hline$£$ & $£$ & $£$ & $£$ \\
\hline 880 & 700 & I 80 & $\ldots \ldots$ \\
\hline 690 & 1,075 & $\ldots \ldots$ & 385 \\
\hline 2,568 & I,978 & 590 & ...... \\
\hline $55^{\circ}$ & $55^{\circ}$ & $\cdots \cdots$ & $\ldots \ldots$ \\
\hline 700 & 700 & $\cdots \cdots$ & $\ldots \ldots$ \\
\hline I 50 & I 50 & $\ldots \ldots$ & $\ldots \ldots$ \\
\hline I9,500 & 20,500 & $\ldots \ldots$ & 1,000 \\
\hline 600 & 600 & ..... & $\ldots \ldots$ \\
\hline 7,000 & 8,000 & ..... & 1,000 \\
\hline I 0,490 & 10,240 & 250 & $\ldots \ldots$ \\
\hline 355 & 295 & 60 & $\ldots \ldots$ \\
\hline 850 & $75^{\circ}$ & 100 & $\ldots \ldots$ \\
\hline $1,75^{\circ}$ & $1,75^{\circ}$ & $\cdots \cdots$ & $\cdots \cdots$ \\
\hline 1,000 & $\mathbf{I}, 000$ & $\ldots \ldots$ & $\ldots \ldots$ \\
\hline I IO & I IO & $\ldots \ldots$ & $\ldots \ldots$ \\
\hline 280,600 & 279,963 & 7,602 & 6,965 \\
\hline 12,000 & 12,350 & $35^{\circ}$ & ...... \\
\hline 268,600 & 267,613 & 7,952 & 6,965 \\
\hline
\end{tabular}


Provision is also made as follows in other estimates for expenditure in connection with this service.

A Further Analysis of Subheads
The Value of These Details

\begin{tabular}{|c|c|}
\hline & I9I4-I5 \\
\hline 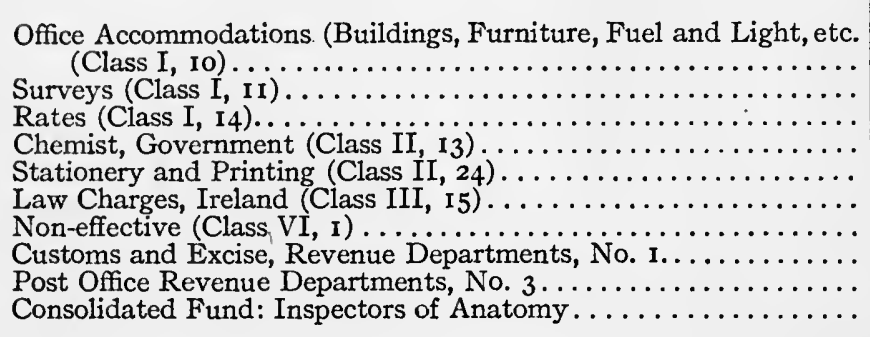 & $\begin{array}{r}8 \\
8,580 \\
2 \\
3,500 \\
550 \\
6,000 \\
150 \\
13,736 \\
50 \\
7,795 \\
600\end{array}$ \\
\hline$£$ & 40,963 \\
\hline
\end{tabular}

Supporting Details. The subheads, which in the tables given are indicated by the letters of the alphabet, represent the furthest that the principle of either appropriation or allotment to particular heads is carried. They do not, however, represent the greatest itemization of data contained in the estimates. For each subhead there is a supporting table giving the details making up the totals shown. These supporting tables are, however, purely for purposes of information. The importance of this supporting detail may be understood when it is remembered that the estimates are not referred to and taken up in a standing committee, but are taken up one vote after another, subhead after subhead, in committee of the whole house, usually beginning in February and continuing till every item has been covered. And it must also be remembered that every member of the House of Commons must go on record before his constituency, when each vote is taken in committee of the whole. The details, therefore, are matters of great interest, especially to the Opposition, who have the cabinet officers before them and can ask them any question concerning which information is desired. In a table supporting the subhead "Salaries and Wages" are 
listed the titles, number, and salaries of all employees to be provided for. Thus for the subhead " $M$ " in the vote for the Home Office, reproduced above, there is given the following table.

Inspection of Coal and Metalliferous Mines and of QUARRIES

(35\& 36 Vict., c. $77 ; 50 \& 51$ Vict., c. $46 ; 57 \& 58$ Vict., c. 42 ;

I \& 2 Geo. V, c. 50 )

\section{Salaries and Allowances}

\begin{tabular}{|c|c|c|c|c|c|c|c|}
\hline \multicolumn{2}{|c|}{ Numbers } & & \multicolumn{3}{|c|}{ Salary of Office } & \multirow[b]{2}{*}{ I9I4-5 } & \multirow[b]{2}{*}{$1913-4$} \\
\hline I913-4 & I9I4-5 & & $\begin{array}{l}\text { Min- } \\
\text { imum }\end{array}$ & $\begin{array}{l}\text { Annual } \\
\text { Incre- } \\
\text { ment }\end{array}$ & $\begin{array}{l}\text { Max- } \\
\text { imum }\end{array}$ & & \\
\hline $\begin{array}{r}\text { I } \\
4 \\
\text { I5 } \\
\text { I } \\
34 \\
\text { I } \\
30 \\
. . \\
\ldots \\
\\
6 \\
\text { I } \\
. .\end{array}$ & $\begin{array}{c}\mathbf{I} \\
5 \\
\mathbf{I} 4 \\
\mathbf{I} \\
33 \\
\mathbf{I} \\
30 \\
\cdots \\
\cdots \\
6 \\
\mathbf{I} \\
. .\end{array}$ & 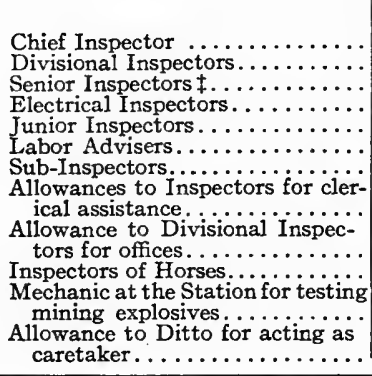 & $\begin{array}{r}£ . \\
\mathrm{r}, 200 \\
750 \\
500 \\
500 \\
300 \\
300 \\
150\end{array}$ & 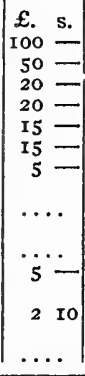 & $\begin{array}{r}\qquad . \\
\mathrm{I}, 500^{*} \\
\mathrm{I}, 000 \\
700 \\
700 \\
450 \\
400 \\
200 \\
\ldots \ldots \\
\ldots \ldots \\
\mathrm{I} 75 \\
\mathrm{I} 20 \\
\text { 5s. a wk. }\end{array}$ & \begin{tabular}{r}
\multicolumn{1}{c}{$£}$. \\
1,500 \\
4,509 \\
8,646 \\
607 \\
11,846 \\
300 \\
4,704 \\
840 \\
210 \\
784 \\
117 \\
13
\end{tabular} & $\begin{array}{r}£ . \\
1,500 \\
3,568 \\
9,367 \\
587 \\
11,909 \\
300 \\
4,596 \\
820 \\
140 \\
758 \\
115 \\
13\end{array}$ \\
\hline 93 & $92 \|$ & & Total & r Salari & es .....£ & 34,076 & 33,673 \\
\hline
\end{tabular}

* Salary to be reconsidered on a vacancy.

t On the organization of the Lancashire and North Wales Division the numbers of these posts will be 6 divisional inspectors and 13 senior inspectors.

$\pm T w 0$ of these inspectors retain the old scale of salary, viz., $600 £ .-20 £ .-800 £$.

II The inspectors have been appointed as inspectors of factories (without additional salary) to enable them to enforce certain provisions of the Factory and Workshop Acts in the Pit Banks, Metalliferous Mines and Quarries.

The itemization of other subheads naturally varies with the subheads and the services to which they relate. The tables given below, showing the supporting tables for the two subClassification Differs with Each heads under the caption of Inspector of Coal and Metalliferous Mines and of Quarries, indicate the extent to which items of this character are detailed. 


\begin{tabular}{|c|c|c|}
\hline N. Traveling and Incidental Expenses. & $1914-5$ & 1913-4 \\
\hline $\begin{array}{l}\text { Traveling expenses of the } 9 \mathrm{I} \text { inspectors, sub-inspectors, } \\
\text { inspectors of horses and the labor advisers .......... }\end{array}$ & $\stackrel{£}{£}$ & $\stackrel{£}{£}$ \\
\hline 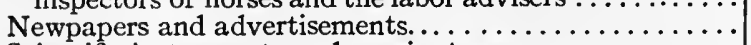 & 60 & 70 \\
\hline Scientific instruments and repairs to same ....... & 50 & 80 \\
\hline 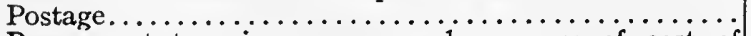 & 460 & 420 \\
\hline $\begin{array}{l}\text { Repayment to mine owners and coroners of cost of } \\
\text { telegrams }\end{array}$ & 60 & 60 \\
\hline Carriage of parcels, cost of photographs and sundries . & 20 & 20 \\
\hline Total for Traveling and Incidental Expenses . . & I 8,650 & 18,650 \\
\hline
\end{tabular}

From Summary to Details

O. Costs of Inquiries, Arbitrations, etc. *

I. Legal and other expenses in connection with inquests, inquiries, and arbitrations, including the cost of shorthand notes, and court fees, etc., in prosecutions conducted by inspectors without legal aid.........

2. Testing of explosives $\dagger$; renewal of apparatus and provision of material (450£); fees of chemical referees $(5 \circ £)$ and incidental expenses $(25 £) \ldots \ldots \ldots \ldots \ldots$

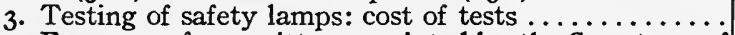
4. Expenses of committee appointed by the Secretary of State to carry out coal dust experiments.........

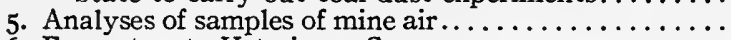

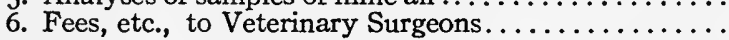

Total for Costs of Inquiries and Arbitrations ....£

\begin{tabular}{|c|r}
$1914-5$ & $1913-4$ \\
\hline$f$ & $f$ \\
& \\
& \\
1,000 & 1,000 \\
& \\
525 & 375 \\
100 & 380 \\
4,500 & 6,600 \\
1,250 & 2,500 \\
100 & 200 \\
\hline 7,475 & 11,055 \\
\hline
\end{tabular}

* The costs of prosecutions and appeals conducted by the Director of Public Prosecutions or the Solicitor to the Treasury are defrayed out of the Vote for Law Charges, Class III, I.

$\dagger$ The fees chargeable for testing explosives are appropriated in aid of the vote. The amount received during the year ended September 30 , I9 I3, was $2,478 £$.

The fines under the Coal Mines and Metalliferous Mines Acts are payable to the Exchequer, and by direction of the Treasury under the Act I \& 2 Geo. V. c. 50, s. 105, those inflicted in England and Wales are appropriated in aid of the Home Office vote. The total amount received in Great Britain during the year ended 3oth September, 1913, was $£ 1,0066 \mathrm{~s}$. IId.

Order of Presentation of Data. The foregoing tables show the great care taken by the Treasury to place before Parliament the details of proposed expenditures in comparison with the figures for the current year. Equally noteworthy is the form or order in which these tables are given. Each of the one hundred and fifty-three votes constitutes a chapter in the book of estimates. At the head of the chapter is given the total amount of the vote. Next follows the table which we have reproduced giving the subheads under which all account- 
ing for the vote must be rendered and between which, as has been pointed out, transfers may, with the approval of the Treasury, be effected. Then follows the series of supporting tables. The principle of presentation is thus the correct one of proceeding from the general to the particular. By this scheme of presentation significant tables are brought into immediate juxtaposition and attention is not distracted by details. If information regarding the latter is desired it can, however, be easily obtained by consulting the supporting tables that follow. Especially to be commended is the series of footnotes having the purpose of explaining any change of importance or of presenting other data explanatory of the figures given. Members of the House are not yet at the end of their resources in these details: They may still ask questions of administration officers on the floor and have them promptly answered.

General Summaries and Analysis. In the foregoing we have been considering the manner in which the details of the estimates are presented. We have now to consider the steps that have been taken to bring these details together into general statements and to compare the showings then made with past experience to the end that the purport of the estimates as a whole may be seen by the legislator.

We have seen that the book of Estimates proper consists of 153 chapters, each devoted to giving the subheads and supporting data regarding a single vote. These chapters are In Four Large Quarto assembled in four volumes embracing respectively the estimates for (I) the Army, (2) the Navy, (3) the Civil Services, and (4) the Revenue Departments. The chapters relating to the civil services are first issued as separate pamphlets, but are afterwards bound up in a single volume with a general index. Each of these four volumes is provided with introductory matter, consisting of: (I) A memorandum explanatory of the estimates; (2) an abstract of the estimates; and Subdivisions of Each (3) a comparison of the estimates with actual expenditure Volume 


\section{BRITISH FINANCIAL ADMINISTRATION}

Memoranda Explanatory of Estimates

during the preceding eight years and grants for the current year. We will consider each of these in turn.

Curiously enough, the memoranda explanatory of the estimates do not in all cases appear as a part of the books of estimates to which they relate. The memoranda for the Army and Navy estimates appear as separate pamphlets, those for the year I9I4-19I5 bearing the titles: Army:-Memorandum of the Secretary of State for War Relating to the Army Estimates for 1914-5, and Navy Estimates 19I4-5: Statement of the First Lord of the Admiralty Explanatory of the Navy Estimates I9I4-5. The memoranda for the civil services and the revenue departments are prepared by the Financial Secretary of the Treasury and appear, in connection with the abstract of estimates and comparison of estimates with expenditures during the last eight years, as an introductory chapter to the volume of estimates for the civil services. The result of this illogical practice is that persons desiring to consider the Army and Navy in connection with the estimates themselves must provide themselves with these additional pamphlets, and those desiring to consider the memorandum relative to the estimates for the revenue departments must seek it not in the book of estimates for those departments, but in the book of estimates for the civil services.

These memoranda are exceedingly brief ; those for the I9I4I9I 5 estimates comprising, for the Army 6 pages, for the Navy I 5 pages, for the Civil Services 9 pages, and for the Revenue Departments one page. They contain little more than a statement of changes made in respect to the grouping of the estimates under votes and subheads. These changes are relatively few; still at times votes are consolidated or one vote broken into two votes. New subheads are provided for, etc. Only in an exceedingly general and summary way do they call attention to and comment upon features in respect to which the estimates depart from current appropriations as regards the amount of money provided for.

Following the memorandum for the book of estimates for 
the civil services, ${ }^{1}$ appear two tables in the nature of a general summary of the estimates in comparison with appropriations for the current year. These are designated as abstracts of estimates. The first of these tables, which is a summary of Abstracts of Estimates the second, gives the figures according to the seven classes into which the civil services are divided. The second gives the same data according to the 120 votes, and in addition indicates for each vote the department that must account for the vote and the net expenditure for the completed year. In order that the character of these important summaries may be clearly seen the first of these tables, which is a short one, is reproduced in full on page 96, and enough of the second table is given on page 97 to show its character.

Following the two tables comparing estimates with appropriations for the current year are two tables bringing the estimates into comparison with actual expenditures during the preceding eight years and grants for the current year. The first of these tables gives the data according to votes. The second is in the nature of a summary of the first, giving the figures by classes only. As the two tables have precisely the same box headings, the reproduction of the second table on page 98 will show the nature of both.

Little comment is required regarding these tables in which the estimates are recapitulated and brought into comparison with past expenditures and current grants. As far as they go it is difficult to see how the form of presentation could be improved upon. It is important to note, however, that the statements do not carry the figures beyond the vote; that is, the I8o main heads under which appropriations are made. If one desires a comparative statement by subheads reference must be had to the estimates themselves, and the comparative statement must be compiled. In view of the fact that many

Comparison of Estimates with Expenditures

Summaries and Comparisons by "Votes" If 


\section{BRITISH FINANCIAL ADMINISTRATION}

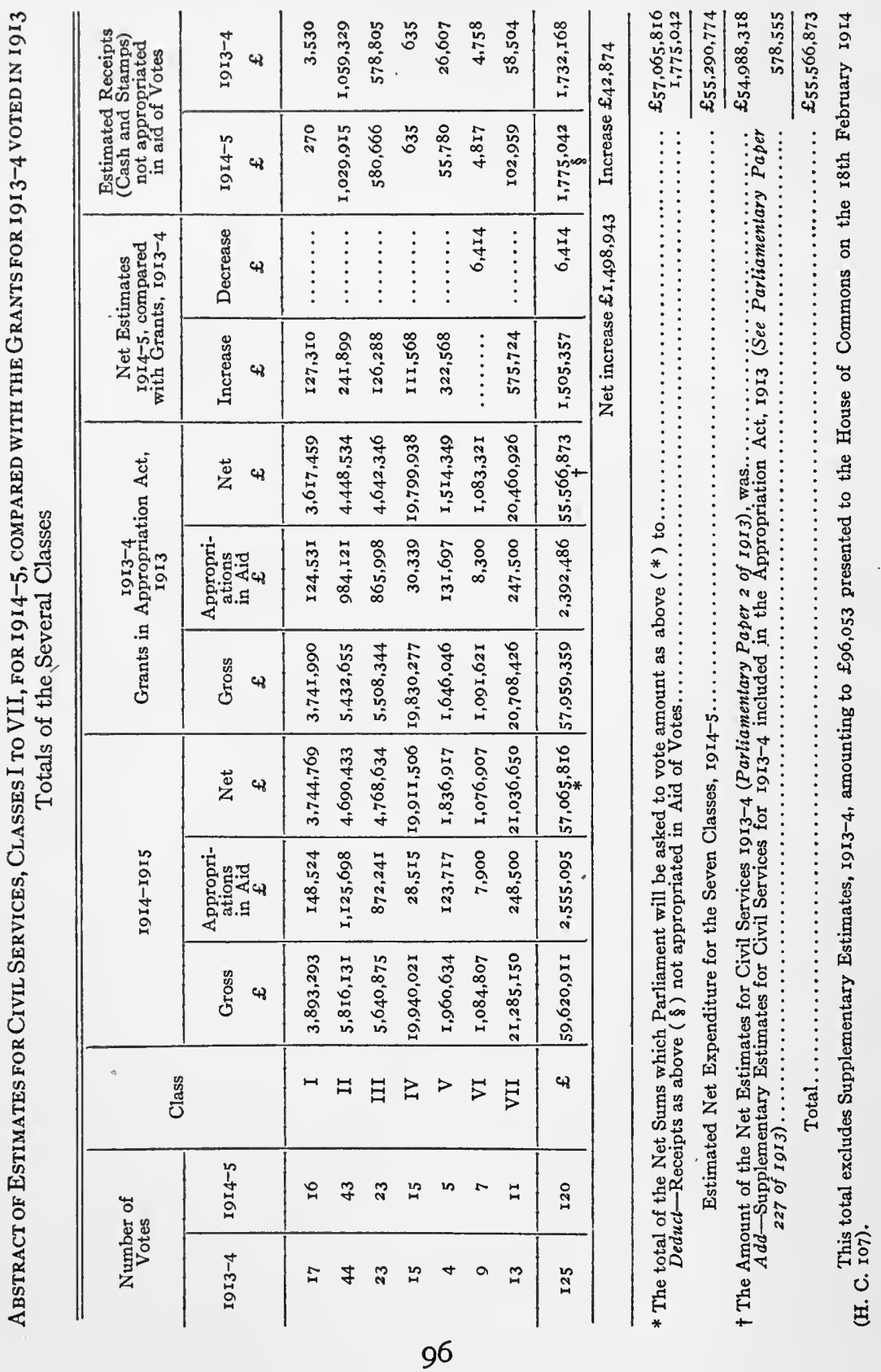


ESTIMATES: CHARACTER AND FORM

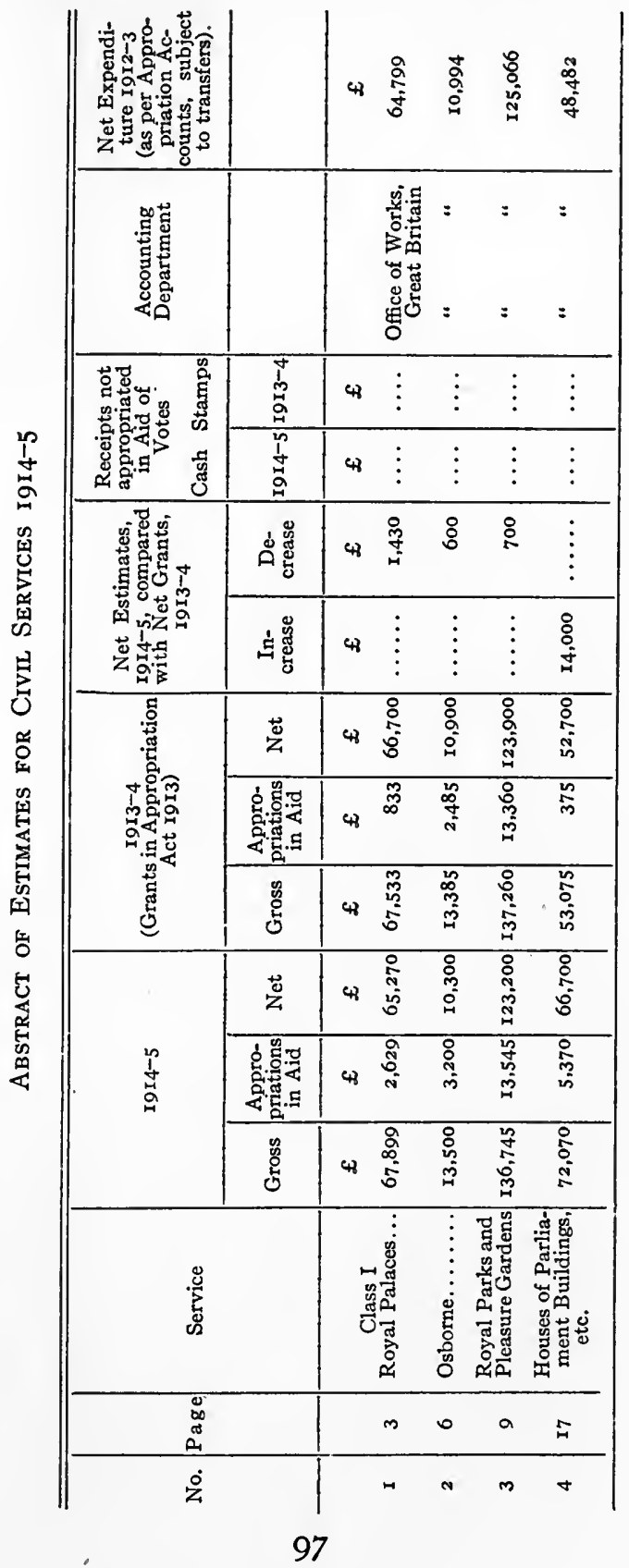




\section{BRITISH FINANCIAL ADMINISTRATION}

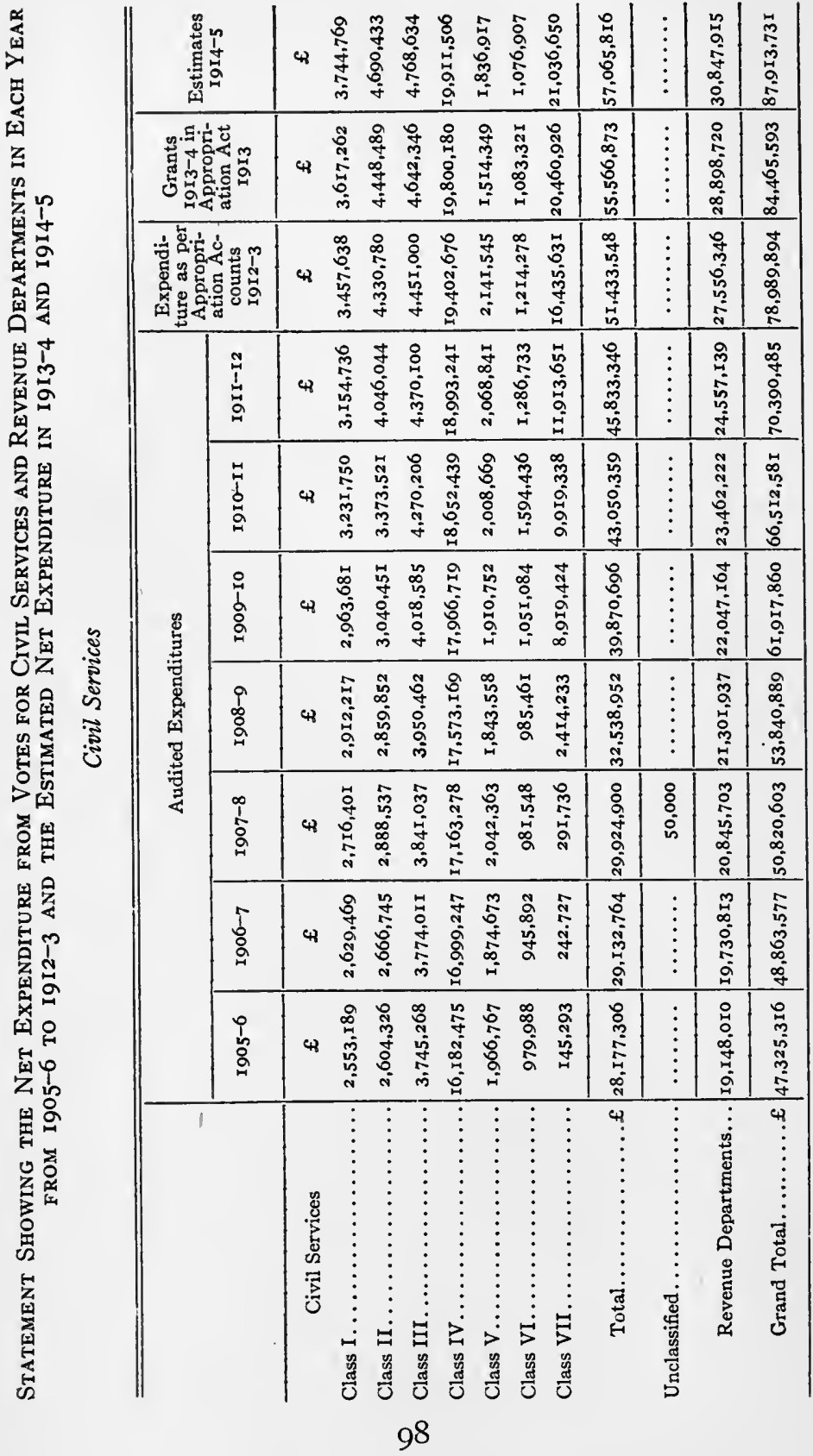


of these subheads are in themselves distinct services of importance, as, for example, Inspection of Mines and Quarries, etc., as shown in the table giving the subheads covered by the appropriation for the Home Office which we have reproduced, ${ }^{1}$ it would seem that the presentation might with advantage be carried far enough to show the figures for these distinct services.

It is also to be remarked that no attempt is made to analyze the estimates from other than the vote standpoint, which, as has been pointed out, corresponds closely to the principle of classification by units of organization. Neither here nor elsewhere is any attempt made consistently to analyze estimates or expenditures according to "objects of expenditure," that is, the things purchased, services, materials, etc.; or according to "character of expenditures," that is, capital outlay, fixed charges, maintenance, operation, etc.; or according to function, that is, the nature of the service except on very broad lines. Each of these distinctions is made; there is a consciousness of their importance, but no basis of analysis or classification is consistently followed in the summaries or details.

1 P. 9r. 


\section{CHAPTER V}

\section{THE ESTIMATES: APPROPRIATIONS IN AID}

Theory of Appropriations in Aid; Statement of Arguments in Favor of the System; Criticism of the System; Contrast with American System of Reimbursable Appropriations.

In the tables which have been given, reference is made to what are called "appropriations in aid"; and through them to a distinction that is made between what are termed "gross appropriations" and "net appropriations." This feature of the estimate and appropriation system is characteristic of the budgetary system of Great Britain. It is one which affects not only the question of appropriations, but the whole scheme of public accounting. It is one, moreover, regarding the advisability of which opinion is widely divided. For these reasons the commission has taken especial pains to inquire into the principles upon which it rests and the results that flow from it in practice.

Theory of Appropriations in Aid. By "appropriations in aid" is meant the appropriation to the services producing them of the miscellaneous revenues or "extra receipts," as they are technically called, as an aid or addition to the funds appro-

A Continuing Appropriation of "Extra Receipts" priated by way of formal grant from the Consolidated Fund. It results from this practice that the several services or groups of services, covered by a vote, receive money with which to meet their expenditures in two ways: ( I) By authorization to use certain of their extra receipts, for, as will be seen, by no means all extra receipts are treated as appropriations in aid ; and (2) by grant from the Consolidated Fund. The latter constitutes the net appropriation, and the two together con- 
stitute the gross appropriation. From the accounting standpoint the significant feature of this system is that the extra receipts treated as appropriations in aid do not pass through the General Treasury and thus do not figure on either the receipt or the issue side of the exchequer accounts. This does not mean that receipts of this character do not have to be rigidly accounted for. It signifies only that they are not accounted for as treasury receipts and payments, but have a special accounting.

According to this system, each service covered by a vote in submitting its estimates is required to estimate, not only the total sum of which it will have need during the ensuing year, but the income that it expects to secure in the way of "extra receipts" which can be used by it to meet such needs. Parliament, in acting upon these estimates, then proceeds to appropriate these receipts as an aid to the vote or appropriation proper, and to make a grant of funds from the Consolidated Fund to meet the balance of the estimated requirements of the service. The amount of the receipts so estimated constitutes the maximum sum that may be used in this way. Should the extra receipts exceed the amount estimated the excess is not available for expenditure, but must be surrendered to the Exchequer as a miscellaneous receipt of the Consolidated Fund.

For the most part moneys assigned to the services in this way represent only incidental receipts, as, for instance, those derived from fees, fines, sale of property, etc. In some cases, however, they are of importance and indeed exceed in amount the total requirements of the service. This, for example, is the case in respect to the Mint, where estimated receipts Character of "Receipts" Appropriated in Aid greatly exceed estimated expenditures. In these cases the practice is to appropriate in aid only so much of the receipts as is necessary to meet estimated expenditures, the balance being surrendered to the Exchequer as miscellaneous income. In order that the income may figure in the estimates calling for a grant, or appropriation proper, the practice is followed of IO̊I 
A "Token" or "Nominal" Vote

The Principle of Financial Entity

making a nominal grant, say, of $£$ Io or $£$ Ioo for the service. This is in order that the estimate for the service may technically come before Parliament for consideration and discussion. A grant of this character is termed a "token" or "nominal" vote. Logically it would seem that this principle of a service relying primarily upon its receipts for the meeting of its expenditures and only requesting a grant from the Consolidated Fund sufficient in amount to meet any deficiency in its receipts to cover expenditures would apply specially to the great revenue departments. In point of fact, however, the principle is not extended to these services. Though, as will be pointed out hereafter, ${ }^{1}$ the revenue departments use the money received by them in paying their expenses, this money from an appropriation and accounting standpoint is treated as having passed through the Exchequer. It is due -to this exception that the term "extra receipts" gets its special signification.

The principle upon which this system rests is apparently that each service shall, as far as possible, be treated as a financial entity-that is, that each service be given a financial personality; that the income derived by a service belongs primarily to it and should be devoted to meeting its expenses; and that only to the extent to which it is unable to meet its expenses in this way should it come to Parliament with a request for a grant of funds from the General Treasury. Combined with this feeing is also the desire to distinguish between expenditures which are met by service receipts and those which have to be met from taxes imposed upon the people. Tacitly, and at times avowedly, the position is taken that the interest of Parliament and the people is in expenditures which have to be met through taxation, and that only these constitute the subject matter of appropriations proper.

In its present form this system was established in I88I as the result of certain observations contained in a report of the ${ }^{1}$ P. I 53. 
Public Accounts Committee in that year. It is now regulated by a statute passed in I89I. ${ }^{1}$

Statement of Arguments in Favor of the System. The matter is one of so great importance that the commission has felt justified in attempting to set forth as fully as possible the arguments that can be brought forward in favor of this system. For this purpose the commission cannot do better than reproduce the statement of the reasons leading up to the adoption of the system and the arguments that can be adduced in its favor as presented by the Public Accounts Committee in a special report that it made on this subject in 1894 , and approved by a treasury minute attached to it. ${ }^{2}$ Under the title "Application of Extra Receipts in Aid of Gross Estimated Expenditure," the report reads :

A question has been raised in the Committee as to the expediency of reconsidering the practice under which the Extra Receipts of the Departments are appropriated in aid of the Grants of Parliament for the respective Services; and the present system has been objected to on the ground that it tends to mislead Parliament as regards the total expenditure for which provision is made.

The question of the mode of dealing with Extra Receipts was under departmental inquiry and consideration. Conditions to $\mathrm{Be}$ for many years, and had been repeatedly under the notice of different Committees of Public Accounts until, finally, it formed the subject of an exhaustive inquiry by the Public Accounts Committee in I88I, in connection with a scheme placed before the Committee by the Treasury in their Minute of 27th June, I88I. In this Minute, the Treasury summarized the objections to the then existing practice as follows:

${ }^{1}$ Public Accounts and Charges Act, 54 and 55 Vict., c. 24, s. 2.

${ }^{2}$ Epitome of the Reports from the Committee of Public Accounts 1857 to 1910 and of the Treasury Minutes Thereon, with an Index, pp. $354-355$. 
(I) The paying of a large proportion of these receipts into the Exchequer, and the consequent voting or revoting of the expenditure which they represent, have the effect of overstating both the public revenue and expenditure, or, as the public understand it, the taxation of the country and the cost of Government, by a sum which may be roughly stated at the present time as more than $\mathfrak{f}_{4,000,000}$ annually.

(2) The departments do not get credit for their receipts and have not therefore inducement to realize them, and thus reduce to the utmost the net charge of Government upon the taxpayers.

(3) Apart from these objections of principle, there is also the objection that, under present practice, there is no uniformity or consistency among the different departments in their method of treating extra receipts.

First Applied to Army and Navy

The Committee of Public Accounts made a separate report on the subject, in which, with the concurrence of the then Comptroller and Auditor General, they approved the adoption of the Treasury proposal to apply the new scheme in the first instance to the extra receipts of the Army and Navy, which they remarked, "though making an important advance in the right direction, must be considered as tentative, and not as a final settlement" (see paragraph 4 of Third Report I88I). The Appendix to the Report of the Committee gives the fullest information of the various stages of the discussion upon this question of the inquiries upon which this scheme was based and of the grounds upon which the expediency of the change was advocated.

The extension of the system to the Votes for Civil Services has only been effected in recent years by a gradual process covering first one vote and then another, as, 
for instance, the Exchequer and Audit Office in $188_{3}-84$, the Diplomatic and Consular Services in $1885-86$. In I892-93 there was a large extension covering 39 votes Gradual Adoption for the Civil (see paragraph 5, Comptroller and Auditor General's Report). But there remains some to which it has not yet been extended (see paragraph 5 above cited). In 1883 the Committee stated that one uniform principle should be observed throughout the services, and recommended a gradual extension of the system to those Civil Service Votes which most readily admit of it (see Second Report I883, paragraph 2).

The change of practice, which originally rested upon directions in Treasury Minutes, has received the statutory authority contained in section 2 (3) of the Public Accounts and Charges Act of $189 \mathrm{I}$.

It is clear, therefore, to your Committee that the conclusions arrived at, after full and complete inquiry, by the Public Accounts Committee of I88I, have been repeatedly affirmed or practically sustained by subsequent committees, and formally approved by Parliament itself in the recent statute above quoted.

It is further to be observed that the system in question does not appear to your Committee essentially to weaken the control of Parliament over the total expenditure, or affect the functions of the Comptroller and Auditor General in his examination and criticism of that expenditure. The gross expenditure and the appropriations in aid are both shown in the Estimates and can be criticized in detail before the vote is taken. If the expected receipts should exceed the estimated expenditure when the estimate is framed, then only so much of them is proposed for appropriation as may leave a nominal balance of expenditure to be voted, in order that the estimate may come under parliamentary review. In that case the overappropriation remainder would be paid into the Exchequer.

Frequently Reviewed, and

Confirmed
Does not

Weaken

Parliamentary Control 


\section{BRITISH FINANCIAL ADMINISTRATION}

Committee

Recommends

Continuation

of Practice

In these circumstances your Committee are not of opinion that any reconsideration of the practice is at present called for, more especially in view of the proposed changes in the appropriation acts dealt with in paragraph 8 of the Third Report of your Committee, which have been recommended for the purpose of strengthening the control of Parliament in regard to the appropriation of the moneys in question.

The Treasury Minute, attached to this report of the Committee on Public Accounts, reads :

T. M. I5/12/94.-My Lords are glad to note that the Committee do not recommend, as a result of their consideration of the subject, any modification of the existing system, as regards the mode of appropriating receipts in aid of voted expenditure. They would strongly deprecate the reopening of a question which formed the subject of exhaustive inquiry and consideration some few years ago, or the revising of a system with the working of which my Lords have every reason to be satisfied.

Criticism of the System. Notwithstanding the fact that this system was adopted after special investigation by the Committee of Public Accounts and with the full approval of the Treasury and Comptroller and Auditor General; received the sanction of Parliament itself through the passage in I8g I of an act authorizing this procedure; was reaffirmed by the Committee of Public Accounts and the Treasury in 1894, and has been tacitly approved by the Select Committee on $\mathrm{Na}$ tional Expenditure in 1902 and by the Select Committee on Estimates in I9I2, the commission nevertheless is not convinced that it is based on a sound principle of accounting or appropriation of funds.

Analysis of Reasons Favoring
In its favor the main argument brought forward is that it avoids an overstatement of revenue and expenditures and consequently prevents the public from being misled in respect 


\section{ESTIMATES: APPROPRIATIONS IN AID}

to what are the real income and cost of conducting the government. Thus, to take an example given by Mr. Higgs: ${ }^{1}$

The War Office receives over two and a half millions sterling annually from the Indian, Colonial, and Egyptian Governments for expenditures incurred for their benefit. If this sum were paid into the Exchequer, and a corresponding amount voted as expenditure, both the taxation and the cost of government would appear to be larger than they really are.

This is an extreme and very special case and is hardly in the category of extra receipts, properly speaking. But even here question is raised as to the force of the argument. It is true that this sum represents services for which the War Department receives remuneration or reimbursement and that the expenditure represented by it does not have to be met out of general taxation. The money none the less represents an activity of the department-a fact which is lost sight of in the net figures of the accounts and estimates.

Is the position to be accepted as sound, that appropriations should cover only grants of money to be met out of the proceeds of taxation or burdens imposed upon the taxpayers in some other form? Is this to be accepted as correct budgetary practice? Should not estimates, appropriation and treasury accounts cover all the operations of the Government? Is there not apparent confusion of ideas in the British system in respect to the cost of operating the Government and the net cost to the taxpayers? The latter fact is one that it is very important to have clearly shown, but this can readily be done by a proper classification of government income and expenditure. It is certainly desirable that the income received by a service should be considered at the same time that the matter of making provision for its expenditures is under consid-

\footnotetext{
${ }^{1}$ Henry Higgs: The Financial System of the United Kingdom, p. II.
} 
Not the

Way to

Promote

Efficiency

A Fundamental Objection

eration. This could, however, be easily secured by requiring the services to submit statements of their income in connection with their estimates for expenditures in much the same way that they are now required to do. This being done, would it not be better to treat these statements of income purely as explanatory data on the expenditure side than have the amounts also appear on the revenue side, and bring out the same net requirements to be met by taxation as at present? Would not this give a more accurate and complete picture of the finances? These are questions that are fairly raised against the present practice.

The further contention is made that this system tends to stimulate the departments in their efforts to secure the maximum revenue possible and to develop increased efficiency. The one contention is based on the assumption that it will decrease the tax rate by increased returns for service; the other is that it may prevent waste. The commission questions the force of this argument also. There is no added elasticity given, no added inducement. The expenditures of the services are as absolutely limited under this system as under that of gross appropriations. If any excess of receipts over estimates as presented in the estimates is received, such surplus cannot be used, but must be surrendered to the Exchequer. If the estimated amount is not realized the services have a ground for submitting a supplementary estimate, and this in fact is the reason often alleged in applying to the Treasury to sanction a transfer or in calling upon Parliament for a further grant of funds.

The really fundamental objection urged against the system, however, is that it complicates enormously the problem of making a consolidated statement of the income and expenditures of the Government. The moment one departs from the policy of rigidly requiring all receipts to be covered into the Treasury and of having all expenditures met by formal appropriations to be paid from such general treasury fund, trouble is encountered in making such a statement. In the I08 
case of Great Britain the evil resulting from its departure from this principle is a real one. As the figures regarding audited receipts and expenditures are not available until some time after a fiscal year is closed, the Chancellor of the Exchequer makes use of exchequer receipts and issues for his budgetary statements. These, moreover, are the figures contained in the "Finance Accounts" or the annual report of Government receipts and expenditures, the document which is most used by Parliament and by the general public in their discussion of matters of national finance. But, as has been pointed out, not all moneys voted as appropriations in aid pass through the Exchequer. The result is that the vital discussion of problems of national finance takes place upon figures which do not include all receipts and expenditures. In fact, so far as the commission is able to discover, no complete statement of all Government receipts and expenditures is anywhere made, and, due chiefly to this system of appropriations in aid, it is doubtful whether such a statement could be prepared without great difficulty, if at all.

What has so far been said in criticism of this system applies to the principles upon which it is based. Were these principles rigidly and consistently adhered to something might be said in its favor. Unfortunately this is not the case. By no means all incidental receipts of the spending departments are applied to meeting their expenditures in the way of appropriations in aid. There are many classes of receipts, which, on account of their amount, their casual character, or for some other reason, are not so appropriated. All receipts of the deThe System Itself Departed partments that are paid through the affixing and canceling of stamps are automatically carried into the Exchequer and thus are not available for appropriation in aid. Finally, there are the cases where receipts exceed estimates. In these cases we have the added complication of part of the receipts from a given source being treated as an appropriation in aid and part as a Treasury receipt.

These theoretical objections do not seem to be overcome in 


\section{BRITISH FINANCIAL ADMINISTRATION}

Inconsistent, practice; in fact, study of the system in operation confirms the Illogical and conclusion that it is inconsistent, illogical and misleading. Misleading Many of the seeming inconsistencies have been pointed out. Among those who have attacked the system is Mr. Harold Cox, ${ }^{1}$ from whose criticism the following is taken:

In the annual estimates presented to Parliament absolutely no attempt at consistency is made. The same department will treat some receipts as Appropriations in Aid of expenditure; others, identical in character, are treated as additions to revenue. A few examples will enable the reader to better appreciate the hopeless confusion which exists in the only accounts formally presented to the House of Commons.

Take this striking fact that the sum to be voted by the House of Commons for the salaries and expenses of the

Statement of Mr. Cox Supreme Court of Judicature in the current year is

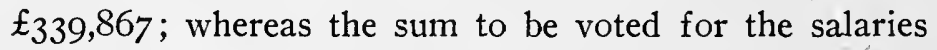
and expenses of the County Courts is only $\mathfrak{E}_{5}$. The explanation is that the fees paid into the High Court are treated as revenue, whereas exactly similar fees paid into the County Courts are treated as an Appropriation in Aid. Absolutely no reason exists for this difference of treating two sets of Court fees. The real cost of the County Courts is not $\mathfrak{f}_{5}$, but $\mathfrak{f}_{496,547}$ plus the sum charged upon the Consolidated Fund for the salaries and pensions of County Court Judges, plus various payments charged to other departments. Nor is the treatment of the County Court fees consistent even with itself, for a footnote to the estimates explains that, in addition to the sum of $\mathfrak{f}_{496,547}$ treated as an Appropriation in Aid, a sum of $£_{4,458}$ is estimated to be received in cash and to be paid into the National Revenue, and that further

1 Official Finance in Government Departments: Financial Review of Reviews, London (1913), pp. 47-49. 
amounts estimated at $\mathfrak{£}_{3} 6,829$ in stamps and $\mathfrak{f}_{450}$ in cash will also be received through the County Courts and added to the revenue.

These grotesque inconsistencies are not confined to large sums which can easily be spotted. They run through the whole system. Here are a few examples, obtained by comparing the figures given in the "Finance Accounts" for 1906-7 with the figures published in the Volume of Estimates applying to that year. The Criminal Lunatic Asylum at Broadmoor receives $£_{50}$ a year as rent from the Berkshire County Council for certain school buildings; it also receives rents for various cottages and other sundry receipts amounting to $\mathfrak{1}_{1} 6_{5}$. The first of these items is treated as part of the National Revenue and is so entered in the Exchequer Accounts; the second is treated as an offset against expenditure, and is entered as an Appropriation in Aid. The British Mu-

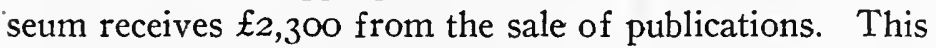
is treated as an Appropriation in Aid. On the other hand, the National Portrait Gallery receives $£$ I 6 is. 5 d. commission on the sale of photographs. This is treated as an item of National Revenue. Fees for admission to the Tower of London are treated as an Appropriation in Aid. Fees for Admission to the National Portrait Gallery and to the National Gallery of Ireland are treated as National Revenue. ...

The Post Office Estimates, as presented to Parliament,

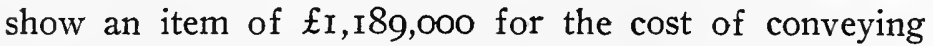
"mails" by railway in the year 1906-7. The "Finance Accounts" for the same year, which are not published until after the year has closed, show that in addition to this sum the Post Office paid to the railways no less than $\mathfrak{E I}_{\mathrm{I}, 032,000}$ for the conveyance of "parcels." This second item is treated as a.deduction from the receipts of the Post Office, and no mention whatever is made of it in the Estimates submitted to Parliament. 
Mr. Cox points to what he considers many other equally glaring examples of inconsistency in the operation of the system of appropriations in aid. We have given sufficient, however, to show how defective this system is held to be by its critics, and how greatly it is held to complicate the problem of determining the true revenues and expenditures of the Government. Certain of these objections could easily be overcome; others, if accepted as such, are inherent in the system itself-as, for example, where receipts treated as appropriations in aid exceed in amount the cost of the services and the surplus has to be turned into the Treasury, and when the extra receipts are paid in through the affixing and canceling of stamps.

Two

Classes of Expendi- tures to Which Applicable

A Reimbursable Fund

Contrast with American System of Reimbursable Appropriations. To the commission there would seem to be but two classes of receipts and expenditures to which this system of appropriations in aid properly applies, and as regards them a much better system of handling them is followed in America. The first case consists of the receipts and expenditures that are entailed in operating a commissariat, supply or other analogous enterprises for the use of employees or the public. Reflection will show that receipts and expenditures produced through services of this character are not, properly speaking, either a government revenue or an expense, but only a change in the form of the resource which may still be held as a fund. It would entail a large amount of unnecessary trouble and accounting if all moneys received in this way were carried into the Treasury and all expenditures for such a purpose were met through formal appropriations. The continuing exchange of cash for goods, the goods for cash without profit or loss adds nothing to income or expense. To treat these exchanges as income and expense would be quite misleading; it is quite as useless to go through a different funding operation every time a stock which is intended for such use is turned over. The first practice would result in unduly swelling both the 
income and expenses. The second would put an unnecessary limitation on the service with no added control. The practice which is best adapted to such a purpose is to treat the appropriation as an impounded fund, to be operated on the theory that there will be no surplus or deficit. Or if there is a small balance of gain or loss on one side or the other, this is the only sum that really affects the Government income and expenses. To this class may be assimilated all industrial or productive enterprises such as the operation of a postal, telegraphic or telephonic system, though here the operations are of such a varied character and the nature of the administrative machinery that has to be provided for their performance is so complex that there are strong reasons for making other special provision for the management of their financial affairs.

The second class is represented by the receipts derived from the sale of materials, supplies and equipment no longer needed by the administrative departments. It is evident that if the receipts from sales of this character are carried into the Treasury as a miscellaneous receipt and an additional appropriation Proceeds from Sales is made for the purchase of new materials, supplies and equipment, the total cost of such articles will appear to be much greater than it really is. Furthermore, and what is a matter of greater importance, the treatment of receipts of this character in this way destroys in large part any incentive upon the services to secure the maximum return possible for such articles. Cases have frequently come to light where services, knowing that they would not profit by any receipts obtained in this way, have preferred to destroy them rather than go to the trouble of effecting their sale and accounting for the proceeds.

In the United States cases like the above are frequently, though by no means invariably, met by the employment of what are known as "reimbursable" appropriations. Under this system provision is made that all receipts of this character shall be credited to the original appropriation from which payments were made for the purchase of the articles sold or 


\section{BRITISH FINANCIAI, ADMINISTRATION}

for the performance of the service rendered. It is unnecessary to say that all such receipts and expenditures must be duly accounted for in the same way as are other receipts and expenditures.

In the opinion of the commission this system serves the

English Appropriations in Aid Do Not

Discriminate end sought for and in a better way than the British system of appropriations in aid. Furthermore it is applied only in those cases where, as has been pointed out, there is special justification for an exceptional procedure. The British system makes no such distinction, but applies its system to extra or miscellaneous receipts generally. ${ }^{1}$

"This question of appropriations in aid and of "interceptions" generally-that is, of permitting certain receipts to be disbursed without passing through the Exchequer-is handled, but not in a very satisfactory way, in two papers filed with the Select Committee on National Expenditure (1902) and presented by it as appendices to its report. The first, by Mr. T. Gibson Bowles, is an attack on the system, and the second, by Sir Edward Hamilton, a defense. The latter was written as a reply to the former. See Report of the Select Committee on National Expenditure (I902), pp. 2I2-2I4 and 223-227. 


\section{CHAPTER VI}

\section{THE ESTIMATES: ACTION UPON THEM IN PAR- LIAMENT}

Financial Powers of Parliament Now Vested Wholly in the House of Commons; Rules of Procedure Governing the Consideration of Estimates in the House of Commons; Distinction between the Authorization of Expenditures and the Appropriation of Funds; Votes on Account; Excess Votes; Votes of Credit; Appropriation Acts; Extent of Control Over Appropriations Actually Exercised by the House of Commons; Establishment in 1912 of the Select Committee on Estimates.

With the Estimates and their supporting data formulated and laid before Parliament, the next step in the chain of operations for financing the Government is the action had upon them by that body. Here we are interested in two things: (I) The procedure employed by Parliament in performing this part of its duties; and (2) the determination of the extent to which the Parliament exercises the power which it legally possesses of modifying the proposals so brought before it for consideration.

Financial Powers of Parliament Now Vested Wholly in the House of Commons. In considering this matter the first. point to be noted is that the powers of the two houses of Parliament are not coördinate as regards this branch of their duties. This has been true almost from the time when the grand Contest council of the king assumed its present form of a Parliament of two houses. From the beginning the constitutional rule has been that to the House of Commons belonged the predominant rôle of initiating all finance proposals, the House of Lords being relegated to the subordinate position of a mere approving body. 
Though there was no question but that all money bills-that is, bills providing for the imposition of taxes or the appropriation of funds-should originate in the Lower House, great uncertainty existed in respect to the powers of the Lords to amend bills of that character coming to it from the Commons. It is not our intention to trace the long struggle between the two houses growing out of this uncertainty regarding their powers in respect to matters financial. The contest, as is well known, culminated in the great constitutional crisis brought about by the rejection by the House of Lords of the LloydGeorge Budget of I909, a crisis which was solved by an appeal to the country through the dissolution of Parliament and a general election. Vindicated in its contention that the House of Lords should not have the power to modify or reject

Settlement of IgII

Lords a Consenting Body Only finance proposals sent to it by the House of Commons, the Ministry introduced and finally secured the passage of the famous Parliament Act of I I I $^{\mathbf{1}}$ by which practically all power over money bills was definitely taken away from the Upper House.

This act also seriously curtailed the powers of the Lords in respect to matters of general legislation. With this aspect of the act, however, we are not here interested. The more important section of the act defining the powers of the Lords over money bills reads as follows:

Powers of the House of Lords as to Money Bills. Section I.-(I) If a Money Bill, having been passed by the House of Commons, and sent up to the House of Lords at least one month before the end of the session, is not passed by the House of Lords without amendment within one month after it is so sent up to that House, the Bill shall, unless the House of Commons directs to the contrary, be presented to His Majesty and become an Act of Parliament, on the Royal Assent being signified,

${ }^{1}$ I \& 2 Geo. V, c. I3. 
notwithstanding that the House of Lords have not consented to the Bill.

(2) A Money Bill means a Public Bill which in the opinion of the Speaker of the House of Commons contains only provisions dealing with all or any of the following subjects, namely, the imposition, repeal, remission, alteration, or regulation of taxation; the imposition for the payment of debt or other financial purposes of charges on the Consolidated Fund, or on money provided by Parliament, or the variation or repeal of any such charges; supply; the appropriation, receipt, custody, issue or audit of accounts of public money; the raising or guarantee of any loan or the repayment thereof ; or subordinate matters incidental to those subjects or any of them. In this sub-section the expressions "taxation," "public money," and "loan" respectively do not include any taxation, money, or loan raised by local authorities or bodies for local purposes.

(3) There shall be indorsed on every Money Bill when it is sent up to the House of Lords and when it is presented to His Majesty for assent the certificate of the Speaker of the House of Commons signed by him that it is a Money Bill. Before giving his certificate, the Speaker shall consult, if practicable, two members to be appointed from the Chairmen's Panel at the beginning of each Session by the Committee of Selection.

\section{Certificate of Speaker}

Section 3.-Any certificate of the Speaker of the House of Commons given under this Act shall be conclusive for all purposes, and shall not be questioned. in any court of law. 


\section{ENACTING WoRDS}

Section 4.-(I) In every Bill presented to His Majesty under the preceding provisions of this Act, the words of enactment shall be as follows, that is to say: "Be it enacted by the King's Most Excellent Majesty, by and with the advice and consent of the Commons in this present Parliament assembled, in accordance with the provisions of the Parliament Act, I9II, and by authority of the same, as follows"

(2) Any alteration of a Bill necessary to give effect to this section shall not be deemed to be an amendment of the Bill.

Comment on these provisions is unnecessary. A reading of them shows that at the present time the decisive power of the purse resides wholly in the House of Commons, except in so far as this may be qualified by the veto power of the Crown, which for two hundred years has not been exercised. In fact the use of an executive veto is quite unnecessary under the rule of parliamentary procedure, adopted about two hundred years ago, making it out of order for a member of Parliament to move to increase any item in an estimate or appropriation bill. If the Executive's own measure is passed it would be idle for him to veto it.

Rules of Procedure Governing the Consideration of Estimates in the House of Commons. In England the rules governing the conduct of business in the House of Commons are known as "standing orders." Though these orders may be modified by any Parliament, certain of them have been so long established and affect so vitally the governmental system,

Finance Rules in the Nature of Constitutional Law and particularly the relations between the Crown and Parliament, that they may be said to be accepted as in the nature of constitutional law. Particularly is this true of the provisions establishing the rules which have been commented 
upon in our chapter on some fundamental features of the English financial system, that no appropriation shall be made except in pursuance of a formal estimate submitted on behalf of the Crown, that individual members have not the right to propose expenditures or even to move the increase of the proposals of the Crown, etc.

Following are the standing orders now in force governing the manner in which estimates are considered and appropriations made :

Standing Orders of the House of Commons on FinanCial Business

\section{Supply and Ways and Means}

I4. This house will, in future, appoint the committees of supply and ways and means at the commencement of every session, so soon as an address has been agreed to, in answer to His Majesty's speech. ${ }^{1}$

15.- (I) As soon as the committee of supply has been appointed and estimates have been presented, the business of supply shall, until disposed of, be the first order of the day on Thursday, unless the house otherwise order on the motion of a minister of the Crown, moved at the commencement of public business, to be decided without amendment or debate.

(2) Not more than twenty days, being days before the 5th of August, shall be allotted for the consideration of the annual estimates for the army,

${ }^{1}$ The language of this rule may be misleading to an American. The word "appoint" does not mean that a special or standing committee shall be appointed, but that, following custom, the House shall at the beginning of the session organize as a committee of the whole for the consideration of the estimates in detail, and shall meet as a matter of course for the consideration of estimates not less frequently than once each week. The estimates may be under review and discussion from February, or earlier, until August. 
navy, and civil services, including votes on account. $^{1}$ The days allotted shall not include any day on which the question has to be put that the Speaker do leave the chair, or any day on -which the business of supply does not stand as first order.

(3) Provided that the days occupied by the consideration of estimates supplementary to those of a previous session or of any vote of credit, or of votes for supplementary or additional estimates presented by the Government for war expenditure, or for any new service not included in the ordinary estimates for the year, shall not be included in the computation of the twenty days aforesaid.

(4) Provided also that on motion made after notice, to be decided without amendment or debate, additional time, not exceeding three days, may be allotted for the purposes aforesaid, either before or after the $5^{\text {th }}$ of August.

(5) On a day so allotted, no business other than the business of supply shall be taken before eleven, and no business in committee or proceedings on report of supply shall be taken after eleven, whether a general order exempting business from interruption under the standing order (sittings of the house) is in force or not, unless the house otherwise order on the motion of a minister of the Crown, moved at the commencement of public business, to be decided without amendment or debate.

(6) Of the days so allotted, not more than one day in committee shall be allotted to any vote on

${ }^{2}$ This means that as a matter of regular rule the estimates may be under discussion in committee of the whole not more than twenty weeks and not later than August 5 . 
account, and not more than one sitting to the report of that vote. ${ }^{1}$ At eleven on the close of the day on which the committee on that vote is taken, and at the close of the sitting on which the report of that vote is taken, the chairman of committees or the Speaker, as the case may be, shall forthwith put every question necessary to dispose of the vote or the report.

(7) At ten of the clock on the last day but one of the days so allotted the chairman shall forthwith put every question necessary to dispose of the vote then under consideration, and shall then forthwith put the question with respect to each class of the civil service estimates that the total amount of the votes outstanding in that class be granted for the services defined in the class, and shall in like manner put severally the questions that the total amounts of the votes outstanding in the estimates for the navy, the army, and the revenue departments be granted for the services defined in those estimates.

(8) At ten of the clock on the last, not being earlier than the twentieth, of the allotted days, the Speaker shall forthwith put every question necessary to dispose of the report of the resolution then under consideration, and shall then forthwith put, with respect to each class of the civil service estimates, the question, that the house doth agree with the committee in all the outstanding resolutions reported in respect of that class, and shall then put a like question with respect to all the resolutions outstanding in the estimates for the navy, the army, the revenue de-

${ }^{2}$ A vote on account is on a credit to be given to the executive for use after April I, the beginning of the new fiscal year for which the appropriations are to be made. 
partments, and other outstanding resolutions severally.

(9) On the days appointed for concluding the business of supply, the consideration of that business shall not be anticipated by a motion of adjournment, and no dilatory motion shall be moved on proceedings for that business and the business shall not be interrupted under any standing order. ${ }^{1}$

(10) Any additional estimate for any new matter not included in the original estimates for the year, shall be submitted for consideration in the committee of supply on some day not later than two days before the committee is closed.

(I I) For the purpose of this order two Fridays shall be deemed equivalent to a single sitting on any other day.

16. The committees of supply and ways and means shall be fixed for Monday, Wednesday, and Thursday, and may also be appointed for any other day on which the house shall meet for despatch of business. ${ }^{2}$

17. Whenever the committe of supply stands as an order of the day, Mr. Speaker shall leave the chair without putting any question, unless on first going into supply on the army, navy, or civil service respectively, or on any vote of credit, an amendment be moved, or question raised, relating to the estimates proposed to be taken in supply.

${ }^{1}$ This is to prevent "filibustering."

${ }^{2}$ The Committee on Ways and Means is also a committee of the whole house sitting for the consideration of the administrative appropriation, revenue and loan bills. 


\section{Public Money}

66. This house will receive no petition for any sum relating to public service, or proceed upon any motion for a grant or charge upon the public revenue, whether payable out of the consolidated fund or out of money to be provided by parliament, unless recommended from the Crown. ${ }^{1}$

67. This house will not proceed upon any petition, motion, or bill, for granting any money, or for releasing or compounding any sum of money owing to the Crown, but in a committee of the whole house.

68. This house will not receive any petition for compounding any sum of money owing to the Crown, upon any branch of the revenue, without a certificate from the proper officer or officers annexed to the said petition, stating the debt, what prosecutions have been made for the recovery of such debt, and setting forth how much the petitioner and his security are able to satisfy thereof.

69. This house will not proceed upon any motion for an address to the Crown, praying that any money may be issued, or that any expense may be incurred, but in a committee of the whole house.

70. This house will not receive any petition, or proceed upon any motion for a charge upon the revenues of India, but what is recommended by the Crown.

7I. If any motion be made in the house for any aid, grant or charge upon the public revenue, whether payable out of the consolidated fund or out of money to be provided by parliament, or for any charge upon the people, the consideration and debate thereof shall not be presently entered upon, but shall be adjourned till such further day as the house shall think fit to appoint, and

"This is to fasten responsibility for every finance proposal on the executive and prevent "log-rolling." 
then it shall be referred to a committee of the whole house before any resolution or vote of the house do pass therein.

Distinction Between the Authorization of Expenditures and the Appropriation of Funds. Although these rules set forth very clearly the procedure followed in voting on the estimates, there are certain features of this procedure that are of sufficient interest to justify special comment. The first of these is the distinction that is made between the authorization of the executive to incur expenditures and the appropriation of the funds with which these expenditures are to be met, or, to use the English expression, between the "voting of supply" and the "provision of ways and means." The former of these two acts is performed by the House sitting in Committee of the Whole on Supply, or more briefly in Committee on Supply; the latter by the House sitting in Committee of the Whole on Ways and Means, or more briefly Committee of Ways and Means.

The procedure followed is this: The House in Committee

The Procedure of Authorization of Supply considers the estimates and by resolution formally approves the several votes represented by such estimates-the effect of which is formally to record the sense of the body. From time to time the Committee of Supply reports to the House in formal session its action in reference to the votes which up to that time have been approved. This action being approved by the House, the latter then goes into Committee of the. Whole on Ways and Means for the purpose of voting the funds called for by such votes in Committee of Supply. The action of the Committee on Ways and Means is in turn reported to the House for its approval. These are in the nature of authorizations of expenditures, but are not acts of appropriation. After this approval has been had the action taken is embodied in a bill which, upon securing the approval of the House, is transmitted to the House of Lords for its action and from them to the king for his assent. It will be 
noted that in neither committee of the whole does discussion take place upon an appropriation bill; only after a conclusion The Act of Appropriais reached is the result embodied in a bill for formal enactment. It is not until the appropriation bill is signed that money is actually made available for disbursement, except in so far as money may be voted on account.

It will not, of course, have escaped notice that the distinction that is here made between the voting of supply and the provision of ways and means is substantially that made in the Congress of the United States between laws authorizing undertakings or the performance of work entailing expenditures, such as public buildings, engineering projects, etc., and the appropriation of funds with which to meet the liabilities so authorized. These authorizations by Congress to undertake projects may run ahead of appropriations hundreds of millions of dollars and may contemplate the making of contracts which it will require years to complete; but the acts authorizing the work remain inoperative until the needed appropriations are madeexcept in so far as certain preliminary steps may be taken, the expenses of which can be met from funds already granted.

Though the distinction is thus the same in both countries, the procedure followed in England has this difference in detail : It is the House of Commons alone which considers estimates and determines what expenditures shall be authorized. The House of Lords participates in the operation only as regards the act of appropriation. Now that the power of the upper house over money bills has been practically destroyed, this may seem to be a matter of no practical importance. It is none the less of interest to note that the theory that to the House of Commons alone pertains the function of considering estimates is one which has always obtained under the British constitutional system. The real importance of the distinction in England is one that in this country has been missed, namely: that on the estimates, in Committee of the Whole on Supply, the administration is able to obtain full discussion and have a vote taken before the appropriation bill is drafted, which puts

Authorizations and Appropriations by Congress

The

Essential

Difference

Between

American and English Practice 
every member on record as to how he stands on every item of the proposed supply. In this country there is no opportunity offered to the opposition for public discussion and no way for the administration to know where the majority stands until the appropriation bill is up for passage, and that is usually toward the end of the session.

Votes on Account. As has been said, the financial year begins on April I. As the estimates are not laid before the House of Commons until February, it is impossible for that body to review and discuss them in detail in committee of the whole, and to act upon them intelligently before the beginning of the year to which they relate. To meet this situation, resort is had to what are known as "votes on account." The Treasury submits an estimate setting forth the total amount required for each of the votes comprehended under the civil services

Act Known as Consolidated Fund Act No. $r$

Vote Restricted to Services Already Authorized and revenue departments as contained in the regular estimates and the amount that the Government will require "on account". for a certain period, say three or six months, and asks that that amount of supply be granted to it. This the House does by a vote on account. On the basis of this vote and the grant of ways and means, as above described, an appropriation bill known as Consolidated Fund (No. I) Act is passed.

In order that final action of the House on the estimates may not be forestalled, votes on account are restricted to services already authorized. It would be exceptional, if it is ever done, to have a vote on account cover a new service. Votes on account are taken only in reference to the civil services and revenue departments. They are not required for the Army and Navy, since the practice is to pass the large votes, say, for the pay of the military and naval forces, prior to the beginning of the fiscal year, and, under the power that these two services have of using, with the approval of the Treasury, money for one vote for other votes, enough money is thus rendered available for all the needs of these services until final action on the estimates is had. 
This device of votes on account serves the same purpose as the resolutions which are passed by the Congress of the United States continuing existing appropriations in force where there is a failure to pass any of the regular appropriation bills before the beginning of the fiscal year. The two actions differ, however, in this respect: The action of the British Parliament is based upon and constitutes a part of the

Similar to Authorizing Resolutions by Congress action in relation to the estimates for the year to be provided for, while the American action but continues the authorization to expend money made for the preceding year. It should furthermore be noted that in the United States resort to resolutions of this character is had only on comparatively rare occasions; in England the passage of votes on account is a part of the regular procedure by which a grant of funds is made for the conduct of the Government. It might seem that the necessity for this action could be avoided by postponing the beginning of the fiscal year to a later date. The present system, however, offers the great advantage that but a short interval of time intervenes between the preparation and submission of the estimates and the period to which the estimates relate. It is believed that this advantage more than compensates for the added complication introduced into the system of voting funds arising out of the use of votes on account. In view of the fact that, as will shortly be pointed out, the House makes no change of any importance in the estimates as submitted, this belief is probably justified. It is questionable, however, whether such a system would work in America, unless responsibility for the initiation of finance measures were placed on the Executive, and the estimates were first taken up for review and discussion in a committee of the whole house, and the attitude of a majority was determined before the beginning of the new fiscal year.

Excess Votes. Under certain circumstances, provided the sanction of the Treasury has been obtained, expenditures can be made in excess of the votes. For this purpose use is made 
Expenditures in Excess of Appropriations to $\mathrm{Be}$ Validated

of the Civil Contingency Fund, a general emergency fund for the Government as a whole, or of extra receipts. All such excess expenditures must be subsequently regularized by the House of Commons. This is done by the Ministry presenting an estimate for the amount so expended and the House of Commons voting in supply what is known as an "excess vote." The money with which to make this vote good is appropriated in the Consolidated Fund (No. I) Act. Action upon an estimate for an excess vote is never had until the matter has been carefully investigated by the Public Accounts Committee of the House, the chairman of which is chosen from the "opposition."

Votes of Credit. A vote of 'credit is a vote having for its purpose the placing at the disposition of the Ministry of a large sum of money, in addition to that provided for the regular conduct of the government, with which to meet some great emergency. The resolution authorizing the grant specifies that the sum is granted to His Majesty "beyond the ordinary grants of Parliament." Votes of this character have been

Authorization to Meet Emergencies passed in order to provide the Crown with the money required for the financing of the great war in which England is now engaged.

Appropriation Acts. We have seen that after expenditures have been authorized in Committee on Supply, and ways and means have been provided in Committee on Ways and Means, and the action of these two committees has been approved by the House, two appropriation bills are drafted and enacted as are other general statutes. The first of these two acts, the Consolidated Fund (No. I) Act, is usually passed just at the close of the financial year. Indeed it is apt to bear the date March 3I. It has for its purpose to appropriate the money required to make good the excess votes and votes on account. It is thus in the nature of a general deficiency act as regards the current year, though for this purpose it has a retro128 
active character, and a provisional appropriation for the year to come. In respect to the latter feature it has this peculiarity, that though the money carried by it is based upon the votes already adopted first in supply and then by the whole House, it is not specially earmarked to meet the expenditures provided for in those votes, but may be utilized for any of the services provided for by existing law.

The second act, the Consolidated (Appropriation) Act, is usually passed at the close of the session. It is thus enacted several months after the beginning of the financial year to which it relates. Though it appropriates only the sum necessary to supplement the grant made by the Consolidated Fund (No. I) Act, it is nevertheless the final and definite authorization for the expenditure of the entire sum voted for the conduct of the Government during the year. In form this act consists of a few brief clauses formally appropriating the total amount carried by it, authorizing the use by the Army and Navy of surpluses on any votes for the meeting of deficits on other votes, provided the sanction therefor of the Treasury is obtained, authorizing the Treasury to raise funds for temporary purposes through the issue of treasury bills, and directing that the money voted shall be applied as set forth in the votes listed in a schedule attached. It will be noted thus that the appropriation act itself carries the itemization of appropriations only so far as the I 53 votes. If information is desired regarding the subheads under which the votes must be accounted for, reference must be had to the estimates. As the estimates specify the votes as well as the subheads, and these estimates are in fact passed as introduced, it is to the estimates and not to the appropriation acts that one turns for information regarding the details of appropriations. ${ }^{1}$

Extent of Control Over Appropriations Actually Exercised by the House of Commons. In our consideration of some of

${ }^{1}$ For copies of both the Consolidated Fund (No. I) Act and the Consolidated Fund (Appropriation) Act, see Appendixes 2 and 3 .

Consolidated Fund Act No. I a Lump Sum Appropriztion

The Regular Appropriation Act Appropriates by "Votes" 


\section{BRITISH FINANCIAL ADMINISTRATION}

the fundamental principles of the English financial system, we have seen that the House of Commons has surrendered, if indeed it ever exercised, the right either itself to originate proposals for the expenditure of public funds, or to increase the proposals submitted to it by the Crown. Theoretically the right remains to it to reduce the amounts called for by such proposals. Were it so minded the House could thus make of itself a powerful organ for securing economy in the expenditure of funds. Actually, however, the House avails itself of this power only when its action is to be regarded as a vote

Control

Limited to

Review, Criticism and Approval or Disapproval

Facilities for Critical Review and Discussion of "lack of confidence." In fact, any modification of the estimates not acceptable to the Ministry would mean a defeat for the latter, because a Ministry cannot stand which cannot count on a majority to support its proposals. A second reason why the power is not exercised is found in the fact that it is the disposition of the House to seek larger appropriations than the Ministry is willing to recommend on its own responsibility. This is of significance since it shows that were the bars let down and the House given the power to initiate proposals for the expenditure of money or to move the increase of Crown proposals, the situation would be not unlike that existing in the Federal and State Governments of the United States, where Congress and the legislatures, rather than the Executive, are responsible for lavish if not wasteful appropriation of funds, and the executive veto alone is relied on to protect the people.

Reduced to its final terms, the function performed by the House of Commons in considering estimates may, therefore, be stated to be that of enforcing responsibility on the Executive for financial planning through review, criticism, and discussion, but not of modifying the proposals of the Government. This being so, it would seem that abundant opportunity should. be afforded for the exercise of this right. In point of fact, a study of the rules and practices of the House shows that the exercise of this right is in practice confined within very narrow limits, and this has been made possible because the right 
is clearly recognized. In respect to no class of business is the form of closure known as "the Guillotine" more rigidly applied than it is to financial measures. Such is the pressure of public business upon its time, that the House has found itself under the necessity of steadily reducing the time that can be allotted to the consideration of the estimates. A reading of the standing orders governing the matter, which have been reproduced above, shows that a maximum of but twenty-three days is allowed for a consideration of all the estimates in committee of the whole. Under these conditions all that is possible for those desiring to discuss the expenditure of proposals of the Government is for them to select a few items for discussion, concentrate their attention upon them and vote all the remaining items without any discussion at all. As Mr. Higgs states, ${ }^{1}$ "the practice now is for the opposition to choose the Votes which shall be set down for discussion, and when the allotted time has been exhausted all the outstanding Votes are passed without debate."

Even this statement fails to bring out the extent to which the estimates are voted without any real consideration of them by the House. The points selected for discussion are, as a rule, not ones in respect to which the opposition wishes to criticize the expenditure proposals of the Ministry; they relate rather to matters regarding which the opposition wishes to criticize the general policy of the Government. The motion that is made to reduce the sum assigned to such items is thus a purely pro forma motion upon which the opposition can base an attack upon some general policy to which the Ministry has committed itself; and as soon as the discussion is concluded the motion is, more often than not, withdrawn. As President Lowell expresses it, ${ }^{2}$ "the real object of the debates in supply at the present day is not financial discussion, but criticism of the administration of the departments, their work

${ }^{1}$ Henry Higgs: The Financial System of the United Kingdom, p. 32 .

${ }^{2}$ A. Lawrence Lowell: The Government of England, Vol. I, p. 30 r. 
The Floor as the Opportunity of the Opposition

What Is Gained by the Open Review of Estimates

being brought under review as their estimates are considered."

In considering this matter it should be borne in mind, however, that the opposition has full opportunity to secure knowledge of how the financial affairs of the nation are being administered through the Committee on Public Accounts, through the Comptroller and Auditor General and through open public question and answer. "Complaint has been made," says Lowell, "that the Government no longer cares what grants are brought forward for debate-leaving that to the Opposition,-or how long the discussion upon them may take, or whether it ends with a vote upon them or not, knowing very well that all these grants must. be adopted under closure when the twenty days expire. This is perfectly true; but on the other hand the procedure gives the fullest opportunity for criticising the administration, and forcing a discussion of grievances, the matters to be criticised being selected by the critics themselves."

What President Lowell says regarding the opportunity that consideration of the estimates, in conjunction with the power to propose pro forma motions for a reduction of an item of appropriation, affords the opposition to criticize the Government of the day may be quite true, though certainly the opportunity is a limited one, except in Committee on Public Accounts. From the standpoint of a critical examination of the estimates themselves in committee of the whole, however, it amounts to almost nothing. Actually it would appear, therefore, that the House not only adopts the estimates precisely as they are submitted to it by the Ministry, but does not even subject them to any real discussion or criticism, certainly not to a discussion or criticism that concerns itself with the details of each proposal.

This being so, the question may be asked: What is the object gained by having these estimates submitted to the House at all as opportunities for consideration of matters of general policy could easily be provided for in some other way? The answer to this question is that this action accomplished two 
very important things: It is an exceedingly effective means for securing complete publicity in respect to the financial operations, past and proposed, of the Government; and it affords the best means for definitely locating responsibility for the conduct of the financial affairs of the nation and ensuring accountability for the manner in which this responsibility is met.

In this connection it is of prime importance to note that this whole system of securing control through publicity depends upon the requirement that such publicity shall be a real and not a nominal one. It is safe to say that this system would break down in a moment but for the completeness and clearness with which the information regarding expenditure, past and proposed, is laid before Parliament, and the procedure which requires the Cabinet members to be present to answer questions or criticism. The power of the Ministry in respect to the expenditure of funds is enormous, but every detail of its action must be done in the open. Furthermore, and what is of equal importance, this system would scarcely be feasible but for the fact that in the Treasury there is an organ, which may be held responsible to a majority in Parliament, whose exclusive duty is to exercise not an intermittent but a day-to-day control over practically all the financial acts of the spending departments, whether these acts relate to the estimating of future needs or to the expenditure of the funds finally granted. Coupled with this is the requirement that all expenditures shall be carefully audited by an officer independent of the Ministry, the Comptroller and Auditor General, the result of whose acts must be reported to the House of Commons and be there passed upon by a Committee on Public Accounts in which the opposition is fully represented. In addition to these is the Select Committee on Estimates, whose work is described below. These features of the British financial system, which will be fully described elsewhere in this report, are here mentioned, since it is of great importance to realize that nothing approaching the adoption by another 
government of the English system for parliamentary consideration of estimates would be feasible unless that government were prepared to adopt at the same time safeguards corresponding to the ones which we have just enumerated.

Establishment in I9I2 of the Select Committee on Estimates. Notwithstanding the general satisfaction that exists in England with the system for the handling of estimates in the House of Commons, there is some feeling that the House should, itself, in some more direct way, concern itself with at least a scrutiny of the estimates laid before it. This feeling found expression in the provision that was made in 1902 for the appointment of a select committee "to inquire whether any plan can be advantageously adopted for enabling the House, by select committee, or otherwise, more effectively to make an examination, not involving criticisms of policy, into the details of national expenditure."

It is of importance to note that, in providing for the appointment of a committee, care was taken to exclude from its province any consideration of matters of policy. It was felt that any attempt to bring into existence an organ that would

Desire of the Majority to Have a More Intimate Knowledge of Estimates share, or in any manner participate, in the responsibility for the determination of a program of work would weaken or dissipate the complete responsibility for the direction of public affairs now vested in the Ministry, and would thus be a direct inroad on that principle of cabinet government and ministerial responsibility which is the keystone to the whole constitutional system of Great Britain. The object sought, therefore, was merely an examination of the question as to whether means might not be devised through which the House might more effectively examine into the details of national expenditure.

This committee made an exceedingly interesting investigation into the whole subject of the system and procedure employed in the framing of estimates, their consideration, and the control of the expenditure of the funds granted. Its two 
reports, ${ }^{1}$ one submitted in 1902 and the other in 1903 , have been of the greatest service to the commission in the preparation of this report. Its final report contains some very interesting remarks and recommendations bearing directly on this matter of providing more effective means whereby the House itself might, if not exercise greater control, at least have a greater opportunity for informing itself regarding financial conditions and operations. In the first place, it pointed out that the discussion which took place on going into Committee of Supply far from furnished an adequate opportunity for a real consideration of financial matters. It said :

Eight witnesses who have had special opportunities of noticing the effect of discussions in the Committee of the House of Commons on Supply gave it as their opinion that for many years past the result was to urge increased not decreased expenditures. Your Committee do not pronounce on this. But we consider that the examination of Estimates by the House of Commons leaves much to be desired from the point of view of financial scrutiny. The Report of the Select Committee on National Expendicolor of the discussions is unavoidably partisan. Few questions are discussed with adequate knowledge or settled on their financial merits. Six hundred and seventy members of Parliament, influenced by party ties, occupied with other work and interests, frequently absent from the chamber during the twenty to twenty-three supply days, are hardly the instrument to achieve a close and exhaustive examination of the immense and complex estimates now annually presented. They cannot effectively challenge the smallest item without supporting a motion hostile to the Government of the day; and divisions are nearly always decided by a majority of members who have not listened to the discussion. Your Committee agree in thinking that the Estimates are used in prac-

${ }^{1}$ Report from the Select Committee on National Expenditure, together with the Proceedings of the Committee, Minutes of Evidence, Appendix and Index," December 4, I902; July 7, 1903. 
tice-perhaps necessarily by the Committee of Supplymainly to provide a series of convenient and useful opportunities for the debating of Policy and Administration, rather than to the criticism and review of financial method and of details of expenditure.

After all, this is high praise for the English financial system, for if, with all the facilities given the opposition to detect irregularities in practice and to raise questions which may be annoying to the administration, only questions of broad policy are made the subjects of attack, there can be little doubt of the fidelity or of the efficiency of management. The demand for a means of independent consideration of the estimates by members of Parliament is largely a majority demand. Various proposals were brought before the committee to make it possible for members who had no first-hand contact with administration to become better informed. One was "that the estimates should as early as possible be referred to a grand committee and should only be discussed in the whole house on report of that committee." A "grand" committee is a large standing committee consisting of not less than sixty nor more than eighty members of the House

Proposal of Grand Committee appointed by the Committee of Selection, 'which has power to discharge members and substitute others during the course of the session, and is distinguished from a select committee in that it lasts throughout the session and does not expire, as does the select committee, when it has made a report uporı the special matter committed to its charge. While tried experimentally in 1882 , two grand committees were established in 1888 and made permanent organs of the House. They were designed to relieve the House of the necessity of debate, and in order to secure the presence of persons who may throw light upon any particular bill, the grand committee may appoint not more than fifteen additional members for the consideration of a particular bill.

The procedure of the grand committee, therefore, to this 
extent takes the place of the committee of the whole house, and naturally the Select Committee on National Expenditure, to which this suggestion was made, did not feel that the House would take kindly to the idea of divesting itself of any of its prerogatives in the consideration of so important a matter as that of the estimates in committee of the whole, and merely said: "We are of the opinion that the House of Commons would be strongly adverse to delegating any of its powers to such a committee."

The action finally recommended by the committee by which the House might exert a more effective scrutiny of estimates, was the creation of a committee to be known as the "Estimates Committee" with a position and functions analogous to those of the Public Accounts Committee, except that it was intended that it would give special attention to the proposals for future expenditures, while the Committee on Public Accounts would give more largely their attention to the past expenditures, in which they would be assisted by the Auditor General, whose duty it is to review and approve or disapprove each transaction in passing. Specifically the recommendation was as follows :

Your Committee are therefore prepared to recommend that such a Select Committee be appointed; that it be called "The Estimates Committee"; that it be appointed continuously in the same way and possess the same powers as the Public Accounts Committee; that in order to combine and unify the machinery of financial control, and as it were dovetail the Estimates Committee on to the Public Accounts Committee, a proportion of members be appointed to sit on both committees; that the Estimates

Select Committee on Estimates Recommended Instead Committee with powers to call for witnesses and papers, not of a secret character, should examine a class, portion or branch of the estimates for the current year not exceeding one-fourth of the whole; that this class shall have been selected for them in the previous year by the Public Accounts Committee, who shall likewise notify the De- 


\section{BRITISH FINANCIAL ADMINISTRATION}

partments concerned and the Treasury; that the Public Accounts Committee, while preserving full discretionary power in the selection of the class or portion of the Estimates to be referred to the Estimates Committee, shall endeavor to pass systematically in review each vote within a limited period of years; that to facilitate examination the selected class or portion shall be presented at the earliest possible date after the day of the meeting of Parliament, and that the consideration of this class by the House of Commons in Committee of Supply shall if convenient be deferred until the presentation of the Report of the Estimates Committee thereupon.

In explaining and defending this recommendation the report says:

We are impressed with the advantages, for the purposes of detailed financial scrutiny, which are enjoyed by Select Committees, whose proceedings are usually devoid of party feeling, who may obtain accurate knowledge collected for them by trained officials, which may, if so de-

Reasons

Urged for Select Committee sired, be checked or extended by the examination of witnesses or the production of documents; and we feel that it is in this direction that the financial control of the House of Commons is most capable of being strengthened. . . .

We consider that if the portion of the Estimates selected were not unduly large the temporal difficulties incidental to their examination would be removed, and that as the Committee would have no power to disallow any expenditure, but only to report thereon, there could be no question of any interference with ministerial responsibility or with Parliamentary control.

If we analyze this proposition of the committee certain points of importance stand out clearly. The first is that the position is taken that there is a real need for a closer scrutiny, 
by the House, of estimates and expenditures. Secondly, it is held that in providing the means whereby such closer scrutiny may be exercised great care must be taken that the principle of ministerial responsibility shall not be weakened. The bad consequences that have resulted from the vesting of financial powers in the Budget Committee in the Chamber of Deputies in France are too well known to make any move in that direction, one that will meet with favor. The third point is that a close scrutiny of estimates and expenditures can be had without infringing upon the principle of responsible government, provided the committee making the scrutiny has no power to disallow items, but has merely the

Does not Interfere with Principle of Responsible function of investigation and report.

It is evident that what was here proposed was the creation of a committee that would have substantially the same functions and powers as those possessed by President Taft's Commission on Economy and Efficiency in the United States, except that it was required to report to the legislative branch. Possessed of no power of direction or control, it would have the duty each year of making a detailed investigation of estimates, organization, methods of procedure, activities and expenditures of some one service or group of services, and reporting the findings to Parliament.

This proposal has much to commend it. The evident reason for the committee is that it may serve in an advisory capacity in review of the estimates, with special attention to the actual needs of the services. It is difficult to see, however, why it was thought necessary to provide for a new committee to perform this work. In the Public Accounts Committee the House already has a committee of the highest standing, composed of members who have made matters of public finance their special concern and who have firmly established the tradition of acting, so far as possible, in a non-partisan manner. It would seem to an outsider that the logical recommendation would have been that Parliament enlarge the powers or duties of the Public Accounts Committee and make of it the one source to 


\section{BRITISH FINANCIAL ADMINISTRATION}

Other

Collateral

Proposals

which the House would look for information concerning the scrutiny of estimate and expenditure matters.

The committee made certain other recommendations looking to strengthening the opportunities of the House to inform itself concerning, and if need be to exercise a greater control over, expenditures. Such, for example, was the recommendation that greater opportunity be given to the House to consider and discuss estimates, that the powers of the Treasury, Comptroller and Auditor General and the Public Accounts Committee be extended. It furthermore found that the House might well be furnished with greater information than had been the case concerning expenditures in the past and the reason for changes proposed in the estimates. This defect, it was thought, could easily be remedied by the Government submitting more detailed data in connection with the estimates. It said thus:

It has been suggested as a means of providing Members with more information that a statistical statement should be presented annually with the Estimates showing the variation of each Vote during a period of ten years. To this should be added a few notes explanatory of any marked rise or fall in certain years. Your Committee approve this suggestion, and they consider that in presenting the Estimates to Parliament more detailed information, especially as to new expenditure might be furnished to the House of Commons in the Memoranda which are now circulated with the Army, Navy and Civil Services Estimates.

This report, though attracting favorable attention, and exercising a certain influence upon public opinion, produced no immediate results in the way of direct action for a period of ten years. In I9I2, however, its central recommendation, that for the appointment of a Select Committee on Estimates, was taken up and put into execution. On April i 7 of that year the House ordered: 
That a select committee be appointed to examine such of the Estimates presented to this House as may seem fit to the Committee, and to report what, if any, economies consistent with the policy implied in those Estimates should be effected therein.

It will be noted that the recommendation of the Committee on National Expenditure, that this committee be made in a way dependent upon the Public Accounts Committee, was not followed. This committee immediately entered upon its work in the spirit intimated in the suggestion of the Committee on National Expenditure. It selected for examination the first year the estimate of the Office of Works and Public Buildings. Its report, ${ }^{1}$ submitted July 25 , I9I2, represents a careful investigation of the affairs of this branch of the public service, and incidentally throws great light on the whole subject of the procedure employed in framing estimates and in particular the effectiveness of treasury control.

In this report, while stating that in its opinion the supervision exercised by the Treasury over estimates constituted a real control, it nevertheless added "that in saying this they would not have it supposed that the criticism of the Treasury What the Committee on Estimates Has Done is all that is required. They hope and believe that the work of this committee will become a very real and useful part of the machinery employed for securing economy and efficiency in the preparation of estimates presented to Parliament."

This is significant as again stating that, notwithstanding the effectiveness of treasury control, the House itself should have and exercise the means of scrutinizing estimates and general methods of administration obtaining in the public services. The suggestion that the committee be continued was acquiesced in. The second report of the committee was made in I9I 3 and deals with the estimates of the Admiralty. The serious weakness of the committee for such work is that it has no staff.

1 Select Committee on Estimates, Report, I9I2. 


\section{BRITISH FINANCIAL ADMINISTRATION}

It is too early to determine just the part that this committee will play in the future.

E. Hilton Young, in his recently published volume on the English system of finance, ${ }^{1}$ says regarding this committee :

Comment of E. Hilton Young

There is a consensus that as an instrument of economy the Committee has not justified all of the high hopes that were held for it at its first appointment. Confronted without preparation with a bulky volume of technicalities, its members, lacking expert knowledge of the details of the administrative work which they are set to examine, must find themselves inevitably very much at sea. Men contending for economy in general are always at a disadvantage when pitched against men contending for expenditure on particulars. For enlightenment the Committee must depend on the officials of the department whose estimate is being subjected to scrutiny and on the Treasury. Now it is those officials who have themselves prepared the estimate, and the Treasury has formally approved it; and although both, we may feel assured, loyally place all means of information at the disposal of the Committee, it is not in the nature of things that under such conditions the department or the Treasury officials should find many imperfections in their own work to which to direct the attention of the Committee. In the result the labours of the Committee are prolonged, but its results are not of commensurate importance. As the fruit of many laborious days spent on the Navy estimates, the chief recommendation was one relating to the supply of tobacco to the sailors. It is not to be wondered at, after the first glow of enthusiasm in I9I 2 was over and when it became apparent to the Committee to what unrewarding labours they were confined by their inhibition from questions of policy, that there has even been a diffi-

${ }^{1}$ E. Hilton Young: The System of National Finance, London, I9I 5 , p. 92. 
culty in securing the needed quorum of five at its meetings. ... .

It is to be feared that the Estimates Committee, unless it can be supplied with a servant and helper in a position similar to that of the Auditor General, is never likely to do very much good; and in the meanwhile it may even do some harm. Until its institution parliamentary criticism was the bogey which intimidated ministers and others extravagantly inclined and made them cautious. The hardiest sinner hesitated at the thought that his extravagance might be made the subject of special criticism and debate in the House. Seldom indeed were any criticisms of the sort made, but the possibility of them had a restraining effect. Now the bogey is materialised and put into a committee room, and turns out to be something of a hollow turnip after all. Virtue is gone out of it. Another ill effect of the new system is that it fixes the time at which criticism will be made, and relieves the departments from all apprehension of unexpected criticism between whiles. At the rate of progress which it has made in the past, the Estimates Committee will get the whole of the estimates scrutinised about once every ten years. Once then that it has undergone its ordeal before the Committee, and no very severe one, each department will know that it has ten years of safety before it. The disappointing result of the Committee's labours, a disappointment due in no wise to the Committee itself but wholly to circumstances of its work for which it is not responsible, is therefore not a matter of indifference. It would be better that its powers should be ended if not mended, and to mend them what is chiefly needed, to judge by the experience of the Public Accounts Committee, is a permanent and independent official of its own as an adviser. 


\section{CHAPTER VII \\ DISBURSEMENT OF PUBLIC FUNDS}

Control of Exchequer Issues by the Comptroller and Auditor General; Grants of "Credits" to the Treasury; Issues of Money from the Exchequer to "Principal Accountants"; The Paymaster General; Departmental "Accounting Officers"; Personal Liability of Accounting Officers; Accounting Officers Not Bonded.

Having reached the point where funds are formally appropriated by Parliament for meeting national expenditures, we have need to consider the machinery and procedure employed in their utilization. This, it will be found, involves a number of distinct operations, the money passing through a number of hands before final payment is made. The motives leading to this splitting up of the work of payment of obligations is due partly to the need for distributing the work so that it can be expeditiously performed, and partly to the necessity for establishing the checks and control that are essential to the securing of full accountability.

Control of Exchequer Issues by the Comptroller and Auditor General. The theory that final control over the expenditure of public funds rests in the legislative branch of the govern-

Functions of Comptroller ment requires that that body shall provide means for ensuring that no money shall issue from the Treasury except in pursuance of express authorization. To this end, most if not all nations operating under this theory provide for an officer to represent it as guardian of the public funds. To this officer, usually known as "Comptroller," is intrusted the duty of examining all requisitions upon the Treasury for funds and of determining whether they shall be honored. If he finds that sanction of law exists for the payment he issues his war- 
rant to that effect, and upon this document, and this document alone, payment is made.

In our account of the Exchequer given in our chapter on some fundamental features of the English financial system, ${ }^{1}$ we have seen that early provision was made in England for an officer of this character. One of the three persons possessing the keys to the strong box was the Auditor, to whom was intrusted the duty of seeing that no money should be taken from the box until proper authority therefor was shown. Almost from the beginning this office was one of great responsibility and power. Mr. Bowles pointed this out in his testimony before the Committee on National Expenditure (I902) where he says: ${ }^{2}$.

"The auditor was an officer of very great importance who had absolute control over the issues, and could refuse them even though he were required to make an issue by the Treasury, if in his opinion the conditions of the issue did not comply with the law. Thus, in I8I I, Lord Grenville, then Auditor of the Exchequer, refused to make an

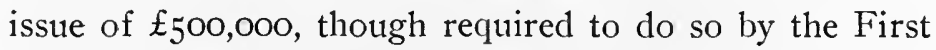
Lord and four other Lords of the Treasury, for want of the due authority from the Crown, which, in consequence of the incapacity of George III., could not then be obtained. Another similar instance occurred in 1832 in reference to the Russo-Dutch loan, when the Auditor's scruples were removed by the opinion of the Law Officers of the Crown."

In 1834 this system was changed by the abolition of the two old offices of Clerk of the Rolls and Auditor and the The Law of 1834 creation of the new office of "Comptroller General of the Receipt and Issue of Her Majesty's Exchequer," to which officer was transferred the duty of seeing that no money should

${ }^{1}$ See p. 36 .

${ }^{2}$ Report, p. 63. 


\section{BRITISH FINANCIAL ADMINISTRATION}

issue from the Exchequer unless warrant of law therefor could be shown and all other legal requirements had been met. Thereafter no money could issue from the Exchequer except upon the order of this officer.

The next change of importance took place through the

Exchequer and Audit Departments Act, 1866 passage of the famous Exchequer and Audit Departments Act of I866, which thoroughly reorganized the whole accounting and auditing system of the Government. In a subsequent chapter we trace the development of the present auditing system which culminated in the act cited by which for the first time provision was made for a complete audit of expenditures by an officer directly responsible to Parliament. An important feature of this act was the consolidation in the hands of one officer of the two functions of control of Exchequer issues and audit of expenditures, which until then had been in the hands of separate officers. This new officer to whom the two duties were assigned was officially styled "Comptroller General of the Receipt and Issue of Her Majesty's Exchequer and Auditor General of Public Accounts," but it was provided by the act that he might be designated by the shorter title of "Comptroller and Auditor General."

Grant of "Credits" to the Treasury. Technically public funds are held by the Banks of England and Ireland subject to the order of Parliament. The latter by statute authorizes the Crown to draw upon these funds for the payment of specified obligations. To make these payments the first step to be taken by the Executive is to get possession of the money, or, what is the same thing, establish at the banks its authority to draw against the public funds. In the United States the procedure employed in performing this operation is an exceedingly simple one. All that is required is that the officers charged with the disbursement of the appropriations shall, from time to time, as they have need of funds, make requisition upon the Comptroller of the Treasury for the issue of warrants directing the payment to them of the sum requisi- 


\section{DISBURSEMENT OF PUBLIC FUNDS}

tioned. The Comptroller, having satisfied himself that the money has been duly appropriated for the purposes set forth in the requisition and that there is a balance standing to the credit of such appropriation sufficient in amount to meet the requisition, executes his warrant directing the Treasury to pay the money called for, and upon this warrant the disbursing officer receives the money.

In England the procedure is much more complicated. The first step required is that the Treasury shall secure formal authority to requisition funds. This is done by securing what In England Treasury Must First are known as "credits" upon the Exchequer. In securing these credits a somewhat different procedure has to be followed in respect to the moneys required for meeting consolidated fund services and those for meeting the supply services. To secure the first the Treasury addresses to the Comptroller and Auditor General a requisition signed by two Lords of the Treasury, asking that the necessary credit be given it upon the Treasury. If the Comptroller and Auditor General finds the requisition a proper one, he approves it and by warrant directs that the credit be granted.

In the case of the supply services the same procedure is gone through, with the exception that before the requisition can be made a royal order must be secured authorizing the requisition. This arises from the fact that in form the supply has been granted to the Sovereign. As the latter is under no legal obligation to make use of the funds so placed at his disposition, unless he desires to do so, nothing can be done until he has signified his wish that the money be placed at the disposal of the Treasury.

Issue of Money from the Exchequer to "Principal Accountants." The execution of the foregoing operations does not result in any actual issue of money from the Exchequer. It merely gives the Treasury the right to order such issue. The issues themselves are made only to officers known as "princiGet Funds pal accountants." Principal accountants are defined by the

Gives Treasury a Right to Draw 
Funds

Received

from

Principal Accountants

Exchequer and Audit Departments Act as "those who receive issues directly from the accounts of Her Majesty's Exchequer at the Banks of England and Ireland respectively." According to Mr. Henry Higgs, the only persons coming under this definition, and therefore authorized to receive money from the Exchequer, are: (I) The Comptroller General of the National Debt, and the chief cashiers of the Banks of England and Ireland, who are authorized to receive money from the Exchequer in order to meet the payments called for by the public debt charges; (2) the Accountants General of the revenue departments who, under an exceptional arrangement which will be more fully described hereafter, can make use of moneys collected by their services for meeting the expenses of the latter, though from a bookkeeping standpoint the money is treated as passing through the Exchequer; and (3) an officer known as Paymaster General, who, with the exceptions just noted acts as a general paymaster for the entire Government service, military as well as civil. ${ }^{1}$

These officers secure funds by making formal requisition therefor upon the Treasury. If these requisitions are found proper the Treasury issues orders upon the custodian banks to transfer the money called for from the credits to the ac-

Requisitions of Principal Accountants Must Be Endorsed by the Treasury

counts of these principal accountants. It will thus be seen that in effect the money is first transferred to the Treasury and by the latter to the principal accountants. The most important point to be noted in respect to this procedure is that the Comptroller and Auditor General does not intervene in respect to the payment of money to the principal accountants. $\mathrm{He}$ has exercised his power of control in the granting of credits to the Treasury. ${ }^{2}$

1 Henry Higgs: The Financial System of the United Kingdom, p. 68 .

${ }^{2}$ For copies of the forms used by the Treasury in requesting the grant to it of credits by the Comptroller and Auditor General, in granting them, and by the Treasury in directing the issue of money from the Exchequer to principal accountants, see Henry Higgs: The Financial System of the United Kingdom, Appendix VII, pp. I $8 \mathrm{I}-\mathrm{I} 88$. 
The Paymaster General. Although, as we have pointed out, there are three classes of principal accountants, two of them have such specialized duties that it will not be necessary to consider them further. Treating them as exceptions to a general rule, as they are, we may say that the English

Chief Paymaster of All Obligations system of disbursing public funds rests upon the principle of having a single Paymaster General for the whole Government. He receives the money from the Exchequer that is required for the payment of public obligations and makes such payment himself or advances money to "sub-accountants" for that purpose. Sub-accountants are defined by the Exchequer and Audit Departments Act as "those who receive advances by way of imprests from principal accountants or who receive fees or other public moneys through other channels."

The Paymaster General, it will be noted, is in no sense an accounting officer. He has nothing to do with the examination and settlement of claims. His sole function is that of making payment of orders drawn upon him by accounting officers proper. His responsibility is limited to that of satisfying himself that the orders for payment are in due form and are supported by the proper documents as required by law. As set forth in a pamphlet issued by the Government descriptive of the financial machinery of the Government: ${ }^{1}$

The Paymaster General fulfills all the duties of a banker for the various public departments, with certain to Spending exceptions. The moneys issued from the Exchequer for the various services are paid to his supply account at the Bank of England. For each of the Civil Service votes he keeps a separate account; but the several votes for army and navy services are included in accounts under the general heads of "Army" and "Navy" respectively. To these accounts he credits the sums issued from the Exchequer, and debits the amount of the various orders

1 "Control and Audit of Public Receipts and Expenditures." Printed for His Majesty's Stationery Offices, London (1907), p. 8. 


\section{BRITISH FINANCIAL ADMINISTRATION}

Acts Reviewed by Accounting Officers
Consolidation of Paymaster Offices

How the System Has Worked

or cheques drawn on him by the several accounting officers. The Paymaster General forwards to the several accounting officers the vouchers in support of his transactions on their accounts; and at the end of every month furnishes to each a statement of account showing his receipts and payments during the month and the balance remaining in his hands. The accounting officer, after examination of this account, forwards to the Paymaster General certificates of the correctness of the total amounts of the receipts and payments included therein. These certificates are subsequently furnished by the Paymaster General as vouchers to his banking account.

Originally there were a number of paymasters, one for the Army, one for the Navy, and a number for the several civil services. During the years 1830 to 1856 they were consolidated into the single office of Paymaster General. The main purpose in view in effecting this consolidation was that of reducing the large number of bank balances called for under the old system. A prime feature of the new system is that, although the Paymaster General keeps a separate account in respect to each vote for the civil services and a separate consolidated account with each of the departments of the Army and Navy, he keeps but one general balance from which he makes payments on account of all the votes. This means that so long as he has a sufficient balance he can pay any order drawn upon him regardless of the vote to which it relates, whether he has requisitioned sufficient funds on account of that vote or not. Any payment on account of a vote in excess of the sum requisitioned for that vote is subsequently adjusted by a future requisition.

This system, when first established, gave rise to some apprehension that it would cause a confusion of accounts and in some way would weaken control of the House of Commons over appropriations. As the result of criticism along this line the Committee on Public Monies of $1856-1857$ made a care- 
ful investigation of the workings of the system, with the result that it gave the following unqualified endorsement. It said :

Your Committee are satisfied, from the evidence taken before them, that the consolidation of the Pay Departments has been attended with public benefit; that it has diminished the balances left in the hands of the Public Accountants to the Crown; that it has increased the security of the public money and promoted economy; and that the regulation which requires the Paymaster General to make all his payments from a single cash balance has been attended with beneficial results. As the issue of money from the Exchequer in amounts sufficient to maintain a constant balance in the hands of the Paymaster, on each separate grant or head of service, over and above the balances in the Exchequer at the credit of such grant and service, would entirely defeat these objects, your Committee recommend that issues from the Exchequer shall be made in order to adjust the payments under every head of service by placing each in credit in the books of the Paymaster as frequently as possible, consistently with retaining the smallest cash balance, and that such an adjustment shall be completely made, at least, at the close of every month; that the Paymaster shall be required to make up, for the Commissioners of audit, accounts to the end of every month, showing the balances for or against every head of service; and that any provision of the Exchequer Regulation Act of 1834 which may appear to be at variance with this mode of conducting the public payments should be repealed. ${ }^{1}$

Notwithstanding this endorsement, criticism of the system continued to be made. One of the objections upon which special stress was laid was that the system destroyed the value

${ }^{1}$ Select Committee on National Expenditure, Rep. Ig02, App. 13, p. 229. 
An Official Description of the Treasury System

of the reports of Exchequẹr receipts and issues as a means of determining national income and expenditure. On February 2I, I885, the Chancellor of the Exchequer took advantage of certain questions addressed to him by Mr. W. H. Smith to make an exceptionally clear and full statement of the disbursing system of the Treasury. This statement was subsequently published as a treasury minute. The importance of the subject warrants our reproducing here the more important parts : ${ }^{1}$

The Departments of the State obtain money for public services by order on the Paymaster General; the service of the Public Debt and of the Revenue Departments constituting almost the only exceptions to this rule.

Sources from Which Paymaster Derives His Funds. ${ }^{2}$ The Paymaster General obtains money from various sources: (I) He receives sums realised by the Departments in the course of their administration (extra receipts rendered available as appropriations in aid without passing through the Exchequer); (2) He holds the balance for the time being of the large fund, called the Treasury Chest Fund, established to meet temporarily expenditure abroad; (3) He holds the Civil Contingencies Fund, established to defray provisionally unforeseen expenditure of a civil character; (4) He also holds large sums on account of what are called Deposit Funds under the control of different Departments of the State; (5) He is supplied day by day, according to his needs, with money from the Consolidated Fund.

Separation of Funds on Books of Paymaster General, But Only One Cash Balance Maintained. These various

${ }^{1}$ See Epitome of Reports from Committees of Public Accounts (I857-1910) and of the Treasury Minutes thereon, pp. I74-I83.

${ }_{2}$ The marginal headings have been inserted by the authors of this report in order to make clearer the several features of the system described. 


\section{DISBURSEMENT OF PUBLIC FUNDS}

heads are carefully distinguished as separate accounts in his books, but he does not at all times keep a separate cash balance upon each head. All receipts under the above heads are treated for the time as part of one general cash balance, out of which he defrays, day by day, the orders for expenditure served upon him; thus he exhausts all cash received from without before he applies to the Treasury for an issue from the Consolidated Fund, and it follows that returns of issues from the Consolidated Fund do not fairly represent the public expenditure, except at prescribed periodical times of adjustment. At those times issues are made from the Consolidated Fund which enable the Paymaster General to replace all the sums of which he has made temporary use for the public service.

Special System for the Revenue Departments. Again, the House sanctions in Supply the expense of collecting the revenue, and it authorises the issue out of the Consolidated Fund to the Revenue Departments of a sum corresponding to the amounts thus sanctioned. The Revenue Departments, however, except in the case of the Telegraph and Packet Service, do not in the first instance make use of this credit on the Consolidated Fund. They defray their expenses of collection out of the revenue as they collect it, and before it is paid into the Consolidated Fund. At regular prescribed intervals, as in the case of the Paymasters' account, the accounts between the Revenue and the Consolidated Fund are adjusted. The Revenue Departments present to the Treasury a statement of the sums which they have expended, and provided always that such sums are within the limits of the Parliamentary authority, the Treasury issues corresponding amounts to the Departments out of the proper Votes, and the Departments repay them to the Consolidated Fund as revenue in adjustment of the amounts temporarily used. These 
methods of procedure may appear somewhat complicated in description, but in practice they are extremely simple. Money is used upon the spot where it comes to hand, because in that manner it can be used most economically. Subsequent adjustment of account between the Departments and the Consolidated Fund brings the expenditure into accord with the Votes of the House of Commons. If that adjustment is not made, if the directions of Acts of Parliament or the regulations of the Service are not observed, or if the expenditure exceeds the sums granted by the House of Commons, the House learns the fact through its own officer, the Comptroller and Auditor General, and, through its own Committee of Public Accounts, judges the infraction of law or regulation thus brought to its notice. ...

Monthly, Quarterly and Annual Adjustment of Paymaster General's Accounts. An adjustment of accounts (as indicated above) of a general character takes place monthly, a fairly accurate adjustment takes place at the close of each quarter, while at the close of the financial year all the precautions are taken which inquiry and experience can suggest, in order that the issues from the Consolidated Fund for the year, as declared within a few hours of the closing of the books on the 3rst March, may correspond as closely as possible with the finally audited expenditure as declared some nine or ten months later by the Comptroller and Auditor General.

Use of Exchequer Issues for Determination of Total Expenditures. The Board is aware that this annual adjustment is not a very simple matter; but its general accuracy is of considerable importance. The expenditure which is given in the Budget, upon which Parliamentary accounts are based, and which is always taken as the public expenditure in discussion by Parliament and the Press, 
is not final expenditure at all; it is a collection of imprests issued out of the Consolidated Fund to the various spending Departments to carry on a service which in several of its branches is spread over the world. It is, therefore, of great moment that these issues from the Consolidated Fund, which are by general assent accepted as representing the Public Expenditure, should correspond as closely as possible with the expenditure as subsequently ascertained by the Comptroller and Auditor General. . . .

After pointing out that the figures for next year showed that the difference between the two was only about one shilling in five hundred or one-fifth of one per cent, the minute continues:

These figures speak for themselves; but the Chancellor of the Exchequer must remind the Board that this accuracy only applies to the issues from the Consolidated Fund after the adjustment which takes place from time to time, and notably at the close of the quarter and of the financial year. At other times the issues from the Consolidated Fund would not be found to correspond so closely with the actual expenditure, because of the various methods adopted for economising the use of the public money. Hence the Returns of Issues from the Consolidated Fund, as published weekly, must not be accepted at other times than those named above as accurate statements of the public expenditure. This point may not be clearly apprehended by the many persons interested in finance who study the weekly returns, and the Chancellor of the Exchequer therefore lays stress upon the fact that the expenditure, as shown in the returns, represents accurately indeed the issues from the Consolidated Fund, but except at the close of the quarter or year it does not accurately represent the actual expenditure. ${ }^{1}$

${ }^{1}$ Subsequent to the date upon which this was written the system of appropriations in aid has been greatly developed, the result of 
Paymasters

Distinguished from Accounting Officers

One Officer to Audit Expenditure against Each Vote

Departmental Accounting Officers. We have seen that under the British system a clear distinction is made between the two functions of paying obligations found to be due and of determining what payments are so due and payable. The first, as we have pointed out, is performed by officers known as "principal accountants," who are really not accounting officers at all, of whom the Paymaster General is the most important. The second is performed by officers who are known as "accounting officers" or "chief accounting officers." Technically an accounting officer is the officer charged with the duty and responsibility for the expenditure of a vote and of rendering an account of the manner in which this duty is performed. This he does by the preparation and transmission to the Comptroller and Auditor General of an account in which the expenditure of the vote is set forth in detail according to the subheads enumerated in the estimates. These accounts, when audited by the Comptroller and Auditor General, are laid before Parliament as the appropriation accounts for the year.

An accounting officer is designated for each vote. Theoretically there might be as many accounting officers as there are votes. Actually, however, the same person is usually made the accounting officer for all the votes for a department or other important branch of the public service. The result is to give to each department or important branch of the public service one official charged with the duty of rendering an account of the manner in which all the funds of that department or service are expended.

This duty of rendering an account of the manner in which funds are expended constitutes but a part of the duties of this officer. Following the principle of concentrating financial responsibility as far as possible, this officer is charged with the supervision and control of all the financial operations of the

which is to exclude from Exchequer receipts and issues important sums received by the department as excess, or extra receipts, and directly applied by them in the way of additions to parliamentary grants. 
department to which he is attached. He is the officer whose approval is required before any expenditure of funds can be made or liability entered into. Moreover, as has been described, he is the official to whom are addressed the estimates circular of the Treasury and who has full charge and responsibility for the preparation of the estimates.

In this officer the British system makes provision for an official, or rather set of officials, who have no counterpart in the federal service of the United States. The nearest analogue to this office is that of the disbursing officers attached to the several departments and bureaus of the federal departments. The accounting officers of the British Government, however, differ radically from these officers in two fundamental respects. In the first place the accounting officers are not disbursing officers; they make no payments themselves; they merely determine what payments should be made. Under the American system the disbursing officers both determine what payments are due and make such payments. In the second place the accounting officer, under the English system, is an official of far greater dignity, official status, and responsibility than the disbursing officer under the American system. The American disbursing officer is little more than an expert accountant with the duty of seeing that all legal requirements are met before payment of a claim is made. He has little or no duty in respect to the determination of what expenditures shall be authorized, other than the technical one of seeing that they fall within the provisions of the appropriation. Though his advice may be relied upon to a greater or less extent by the head of a department in respect to the incurring of obligations, and suggestions from him looking to the effecting of economies may be welcomed, the giving of such advice and suggestions constitutes no part of his official duties. Only in a very limited degree, therefore, is he responsible for the preparation of the estimates setting forth the financial needs of the service or for the economy and efficiency with which the funds granted are expended. 


\section{BRITISH FINANCIAL ADMINISTRATION}

High

Dignity of

English

Accounting

Officer

The English accounting officer, on the other hand, is the one responsible financial officer of the service to which he belongs. He has entire charge of the financial operations of his service. He is responsible for the collection of the extra receipts of the service, all expenditures and the rendition of the accounts. His duties pertain not only to the settling of accounts, but to the incurring of the obligations in the first instance. He has the duty of seeing not only that the law is strictly complied with, but that all expenditures are made to the best possible advantage. $\mathrm{He}$ is in every sense the financial watchdog of his service, and the one upon whom definitely rests responsibility for the efficiency and economy with which the affairs of the department are managed and the funds estimated for and expended. $\mathrm{He}$ is, in a word, the permanent financial secretary of his department.

It is impossible to lay too great stress upon the importance of this officer from the standpoint of securing efficiency and economy in the expenditure of public money. Valuable as is the control over expenditures exercised by the Treasury, such control cannot possibly reach the point of ensuring that expenditures in all cases correspond to real needs, or that the maximum return for expenditures is had in the way of services rendered or goods received. These are features of control that must primarily be exercised inside the several administrative services. In making provision for an officer of this character, in defining the scope of his duties and powers, in giving to him a position of high dignity and authority, and in concentrating upon him all financial responsibility, the British system has gone as far as it seems possible to go in meeting this primary requisite for an economical and efficient administration of financial affairs.

This matter of the responsibility of accounting officers in

Inquiry into Work of Accounting Officers respect to the incurring of obligations and of seeing that moneys voted are expended to the greatest possible advantage was carefully inquired into by the Committee on National Expenditure of 1902. All of the accounting officers who were 
called upon to testify regarding their duties were emphatic in stating that they considered the exercise of such discretion as clearly within the scope of their duties. Treasury officials, in giving their evidence, testified to the same effect. Though anxious to magnify the effectiveness of treasury control, they nevertheless stated that their control largely ceased at the point where the wisdom of the expenditure was determined; that they had to look to the accounting officers of the several departments to see that the moneys devoted to these purposes were applied to the best advantage. Thus Mr. Robert Chalmers, one of the principal clerks in the Treasury, that is, one of the officials through whom control over expenditures is exercised by the Treasury, when asked the question: Now I want to ask you a question with regard to the Accounting Officers of the Departments over which you exercise control. To what extent are they financial controllers, or financial officers exercising power in the interests of financial control? replied :

"They undoubtedly do act very much indeed in the direction of financial control. We undoubtedly look to the Accountant General of the Army and the Accountant General of the Navy as the people inside the Department whose disposition is towards economy, and who do scruReport of Committee tinise expenditure to see that the money expended is expended to the best advantage; and I believe if you inquire from the Accountants General of the Army and Navy, you will find that that is a very considerable portion of their work, and that they understand it to be within the scope of their duty." 1

Regarding the fact that the accounting officer is directly responsible for the management of the financial affairs of his department, and that this responsibility is a real and not a nominal one and cannot be shifted to the shoulders of subordiTreasury Minute Describing nates, the Treasury Minute of August I4, I872, through which Duties

${ }^{1}$ Report of Committee on National Expenditure (1902), p. $3^{3}$. 


\section{BRITISH FINANCIAL ADMINISTRATION}

the present system was definitely established, is very emphatic. It reads : 1

$\mathrm{He}$ signs the Appropriation Account, and thereby makes himself responsible for its correctness. This officer is the person whom Parliament and the Treasury regard as primarily responsible for the balance in the custody of the department, although he himself may not hold one farthing of it. In respect of him, every person having charge of any portion of the money issued to, or received on behalf of, the department, is simply in the position of a subaccounting officer. It cannot be too distinctly announced that responsibility for the proper conduct of financial business cannot be delegated to the subordinate officers who may be placed in charge of the Departmental Accounts. The signature appended to the Appropriation Account would be otherwise an idle form, calculated only to mislead Parliament.

Manifestly an officer having this large responsibility should be one having a position of corresponding dignity and power. Thus the Treasury Minute from which we have just quoted says: ${ }^{2}$

It cannot be doubted that the officer entrusted with the duty should occupy a sufficient standing to enable him not only to exercise a direct supervision and control over the persons executing the detailed business of account and bookkeeping, but also to influence the working of his department in all those respects which affect the method of its receipts or expenditure. He must also be qualified to represent his department before the Parliamentary Committee of Public Accounts. These conditions are satisfied in the permanent chiefs of the various departments. They are responsible for the general conduct and

1 Epitome of the Reports from the Committee of Public Accounts (1857-1910) and of the Treasury Minutes thereon, pp. 31-32.

2 Epitome, etc., p. 34 . 


\section{DISBURSEMENT OF PUBLIC FUNDS}

for the discipline of their departments. They have the best means of acquiring a personal knowledge of the staff placed under their orders, and their functions would be logically incomplete if they were not held responsible for the due discharge of financial as well as other business transacted in their departments.

My Lords (of the Treasury) are therefore prepared to lay down the rule that, in the exercise of the powers conferred upon them by the Exchequer and Audit Act, they will nominate, whenever it is practicable, the permanent heads of the departments to render the Appropriation Accounts of grants for the services under their control. As, however, there may be reasons for making, in some instances, exceptions to this rule, my Lords will not issue final directions until an opportunity has been afforded to the departments to express an opinion upon the proposal, and they will be prepared to give their careful consideration to any representation which may be made to them.

This quotation brings out two important features of this system. The first is that the designation of the accounting officer is made by the Treasury and not by the department for which he acts. It would seem almost as though the theory was that responsibility for the conduct of the financial affairs of the several departments rested primarily on the Treasury and that in discharging this responsibility it designated a high official in each department to act as its agent. The second is that the policy is pursued of vesting financial responsibility, as far as possible, in the hands of the officer exercising administrative responsibility. This means that the persons responsible for the preparation of the estimates and the rendering of the accounts shall be the ones responsible for the authorizing of the incurring of liabilities and the approval of expenditures. It follows from this that the responsibility of this officer is not a mere technical one such as would be the responsibility

Accounting Officer Responsible to the Treasury 
of an accountant or disbursing officer of the ordinary type, but one comprehending the discretion and judgment displayed in determining needs and in expending funds. In a word, it brings responsibility home to the person upon whom such responsibility rests.

Personal Liability of Accounting Officers. An important feature of any disbursing system is the extent to which the officer making or authorizing the expenditures is personally and pecuniarily responsible for any improper payments made or authorized by him, and the manner in which this liability

Command of Superior Officer No Defence in United States
In England Responsibility Centralized can be avoided or discharged. In the United States Government the disbursing officer is not only personally liable for all improper payments made by him, but this liability extends even to those cases where he makes the payment under protest on the command of a superior officer. He is thus placed in the peculiar position that at times he has to choose between refusing to make a payment ordered by his superior and thereby incurring the displeasure of the latter or even running the risk of dismissal from his office, or of making the payment and running the risk of having the item disallowed in his accounts and then being held responsible financially for the payment. The law, in other words, is that a disbursing officer cannot allege a command from a superior officer as justification for making a payment.

In England the law is different. Under the British system the accounting officer can relieve himself of liability in all cases when he has made a payment upon the command of a superior officer, provided he can show that before he did so he made a formal protest against such action. This point, concerning which there was for some years considerable uncertainty, was finally cleared up by a circular letter addressed to all accounting officers by the Treasury in 1883 . This circular reads: ${ }^{1}$

${ }^{1}$ Epitome of the Reports from Committee of Public Accounts (1857-1910) and of the Treasury Minutes thereon, p. I32. 
Accounting Officers will understand that if they are desired by their superior officers to order a payment which, under Act of Parliament, Order in Council, Queen's Warrant, Treasury Minute, or otherwise, they. Treasury Order on believe to be wrong, they must represent their objection, and the reason for it, to such superior officer in writing. If the order is then repeated in writing, they may obey without further responsibility, but if the officer directing the payment is not the supreme chief of the Department they should ask to obtain the authority in writing of such chief before obeying. The responsibility is then transferred to the directing officer, who will be held personally liable.

This principle, the commission believes, is the correct one. It should be stated that under the American system the disbursing officer has the right, in all cases where he is doubtful, of the propriety of making a payment, to call for the opinion of the Auditor, and, if need be, of the Comptroller, before making the payment. It is doubtful whether many, if any, cases occur where a disbursing officer is directed to make a payment after the Auditor or Comptroller has declared such a payment to be an improper one.

Accounting Officers Not Bonded. Another feature in respect to which the British system differs from that of the United States is in respect to the matter of requirement of bonds from financial officers. In the United States Government disbursing officers are required to give heavy bonds conditioned upon their giving a full accounting for all moneys coming into their hands and for all payments made by them. In England no bonds are required of accounting officers. The explanation given why no such requirement exists is that the

British Government Carries Its Own Insurance Government has ample protection in the high positions occupied by these officers, in the fact that these positions are only reached after years of service during which the integrity and 
ability of the incumbent have been thoroughly tested, and in the sums of money in possession of the Government represented by the accrued value of the service pensions to which the accounting officers are entitled upon retirement. Certain it is that in practice the British Government has suffered little or no loss through the inefficiency or misconduct of these officers. 


\section{CHAPTER VIII}

\section{TREASURY CONTROL OVER EXPENDITURES}

Expenditure of Appropriations Not Mandatory; The Treasury the Authority for the Authorization of Expenditures; Treasury Control Over Organization and Personnel ; Treasury Control Over Expenditures for Quarters, Equipment, Supplies, etc.; Organization of the Treasury for the Exercise of Its Powers of Control; Treasury Use of Departmental and Interdepartmental Committees of Investigation; The Treasury as a General Organ of Administrative Control.

In our consideration of the manner in which the estimates are prepared and submitted to Parliament, we have seen that, subject to a possible appeal to the Cabinet as a whole, the Treasury exercises complete control in respect of the determination of the funds that Parliament shall be asked to grant to the Crown for the conduct of the Government. We have now to consider the powers possessed by this department in controlling the expenditure of these funds after they are granted. Great as are the powers of the Treasury over estimates, we will find them scarcely less over expenditure.

Expenditure of Appropriations Not Mandatory. The starting point in considering this phase of the functions of the Treasury is the recognition of the fact that under the English system the expenditure of appropriations is not mandatory. In form appropriations are mere grants to the Crown to be used by the latter as required for the conduct of the Government. As Maitland picturesquely puts it: ${ }^{1}$

Authority to Spend a Grant Not a Command

"Money is granted to the queen; it is placed at the disposal of her and her ministers. But she and they are not bound by law to spend it, at least not bound by the Ap${ }^{1}$ F. W. Maitland: Constitutional History of England, pp. 445-446. 
propriation Act. Of course, if the queen's advisers withdrew all ambassadors from foreign courts, or disbanded the navy or the like, they might be severely blamed and possibly they might be impeached. But statute does not say to the queen: 'You shall spend so much on your embassies, so much on your navy.' Rather its language is: "Here is money for this purpose and for that; spend it as you please; we trust the discretion of your advisers; the account of the expenditure will be presented to us, and votes of censure may follow.' . . . The fact that parliament has voted a supply to the queen for the payment of such salaries or pensions does not give them a remedy against the lords of the treasury or the secretaries of state who are charged with the expenditure. No one can say: 'Under the Appropriation Act, the secretary of state for war or the lords of the admiralty, have received money which they hold upon trust for me." "

The Treasury the Authority for the Authorization of Expenditures. It follows from this principle that something more than the mere appropriation of funds is required by the services before they can proceed to the expenditure of the funds that have been granted to the Government for their support. As the funds have been granted to the Crown the Crown must

Mandate Must Come from Executive indicate the desire that the money shall be spent. It is at this point that the power of the Treasury to control expenditures enters. Just as the Treasury is the organ through which the Crown formulates and makes known its wishes regarding its financial needs, so it is the organ through which the Crown afterwards determines the extent to which it will utilize the funds that have been granted to it and the conditions that shall be observed in their utilization. Moreover, just as the power of the Treasury to frame estimates is not a nominal one, but carries with it the exercise of a determining voice as to what funds shall be asked for, so this second and complementary function of controlling expenditures is equally a real one. 
Theoretically every expenditure, as every estimate, must receive a treasury sanction. In practice this means that when the expenditures contemplated are for purposes that have preMust Be Sanctioned viously been authorized, and do not call for a larger sum than by Treasury has already been approved, treasury sanction will be taken for granted, unless the Treasury has for some reason decided that a retrenchment is necessary and so directs. But where any departure from prior practice is proposed, the employment of a single additional clerk, the undertaking of any new work, the express sanction of the Treasury must first be obtained before any action can be had. Speaking to this point, Mr. William Blain, clerk in charge of estimates in the Treasury Department, in his testimony before the Committee on $\mathrm{Na}$ tional Expenditure of I902, said : ${ }^{1}$

"Apart from what one may call the necessary normal expenditure of the Department, new proposals, new departures, and new programmes must always come to the Treasury for sanction, and that is quite a separate matter from the approval of the Estimates. . . . The passing of the Estimate does not necessarily sanction the expenditure. Taking the case of an Establishment (i.e., a personnel) beyond its necessary strength, the mere fact that the Treasury have approved of the Estimate which the Department was submitting to Parliament would not authorise the Department to increase its establishment. If the Estimate contained an establishment showing an increase over that of the previous year, they would still have to get a separate Treasury sanction for the increase of that establishment, and the Audit Office would not pass its expenditure without that."

Another leading authority on the British financial system puts it in this way, ${ }^{2}$

1 Report of the Committee on National Expenditure, I902, p. 3.

${ }^{2}$ Henry Higgs: The Financial System of the United Kingdom, pp. $82-83$. 
Powers of

Control

Independent

of

Expending

Depart-

ments

"The powers of the Treasury are very great, resting partly upon the prerogative of the Crown in so far as the exercise is committed to the Treasury in the matters of finance, and partly upon a variety of statutes. Section 27 of the Exchequer and Audit Act, I866, gives it practical control over the whole public expenditure and enables it to require that any measure tending to increase that expenditure should be submitted for its concurrence before it is adopted under pain of being disallowed. Proposals for the increase of establishments (i.e., personnel), increased rates of pay, additional services or new works, require Treasury sanction, and are questioned by the Auditor General if they are put in force without the authority of the Treasury. By reason of its central position the Treasury undertakes the regulation. of general questions affecting the organisation of the Civil Service at large, prepares Orders in Council governing the service, and issues circulars designed to promote uniformity in the treatment of officials in different departments. The bulk of its departmental business consists of the control of expenditure by the examination of proposals for increased pay or establishments or new services, for all which it requires full justification, and the award of pensions for the Civil Services."

In weighing the significance of these broad powers of finan-

Control

Goes

Beyond

Regularity and Authority cial control it is important to appreciate that they exercise them not in the way of approving expenditures proper, that is, in passing upon orders, vouchers, contracts, etc., but in the approval or disapproval of actions which will give rise to the necessity for increased expenditures. Its control, in a word, is one over the incurring of liabilities, over the program of work, the plant, organization, personnel, equipment, etc., that shall be employed for the conduct of Government operations. Its power in respect to these matters is practically absolute. Through it and through the approval of proposals for the expenditure of I 68 
funds, the Treasury thus is in effect a general board of administrative control. Among the many striking features of the British financial system none is more noteworthy than this. It is our purpose, therefore, to consider in some detail the manner in which the Treasury exercises this exceedingly important function.

Treasury Control Over Organization and Personnel. The estimates, as we have seen, contain tables showing for each service the number and compensation of all employees to be provided for. These detailed statements of organization and personnel are, however, purely for purposes of information. Legislative determination of how the services shall be organized and the number and compensation of employees goes no further than the allotment of lump sums for the subhead "Salaries and Wages," and even this allotment can be changed through the effecting of transfers from one subhead to another upon the approval of the Treasury being obtained. Though Parliament is thus given as full information regarding organization and personnel as is furnished by the estimates of the United States Government to Congress, there exists nothing approaching the practice of the latter body of appropriating in detail for specific positions and rates of compensation. Under the British system practically the whole matter of organization and personnel is left to executive determination.

The authority through which this determination is had is the Treasury. Though there are general statutes governing the classification and compensation of personnel, practically full discretion is exercised by the Treasury in applying these general rules to particular services. The organization and personnel that each service now has is the result of past action on the part of the Treasury. This organization and personnel each service retains until it has received an authorization from the Treasury to effect a change in respect to them. It results from this that the Treasury is constantly passing upon applications

Executive Responsibility for Organization

Treasury Control Agent of Chief Executive 
for changes and is thus constantly passing in review the administrative organization and problems of the several services.

It is hardly necessary for us to point out how effective a system of control this procedure provides and how it dovetails into the work of the Treasury in determining the estimates that shall be put forward each year. It means that no increase can be made until an independent authority has been convinced of its necessity. The mere fact that all increases must be so justified even though approval may follow almost as a matter of course-which, however, is by no means the case - constitutes a powerful deterrent upon increases not warranted by the public needs.

Control

Over

Salaries and

Personal

Administration

Neither is it necessary to dwell upon the superiority of this system over the one obtaining in the United States, where the attempt is made to determine in detail the number and compensation of the personnel of each office by legislative act. Under the British system this determination is made by an authority in intimate and constant touch with the working conditions of each service and thus technically competent to perform this difficult task; and the determination is made item by item as needs for changes arise. The system resulting is thus one in which strict control is combined with great flexibility. Under the American system this operation is performed by a body with a fluctuating personnel not directly or currently in touch with administrative problems; the determination is had'at one time, months in advance of the time when the decision made will go into effect, and no provision is made for effecting readjustments as new conditions present themselves. Knowing this, each service seeks to obtain the maximum force that it can persuade Congress to grant it, in order that it may be on the safe side. To the British system of effective control and great flexibility the United States opposes one of ineffective control and great rigidity.

Treasury Control Over Expenditures for Quarters, Equipment, Supplies, etc. Practically the same principles which we 
have set forth as governing expenditures for personnel apply with respect to expenditures for quarters, equipment, supplies, and like objects. In performing the function of control in respect to these classes of expenditure the Treasury, however, makes use of two special organs: His Majesty's Stationery Control Over Purchase and Custody of Office, which attends to all matters connected with the furnishing to the several services of stationery and the execution of the printing required by them; and the Office of Works and Public Buildings, which in like manner attends to the furnishing of the services with quarters, building supplies, etc. The most interesting feature of these two services is that they are not merely the two great central supply services for the whole Government, but organs of control in respect to expenditures for the services and supplies furnished by them. The operations of these two services constitute such an important feature in the general scheme of the English Government for controlling expenditures that the commission has thought it desirable to describe their organization and methods of work in some detail. This is done in the two chapters which immediately follow the present one.

Organization of the Treasury for the Exercise of Its Powers of Financial Control. In the foregoing we have seen that the Treasury Department of Great Britain is in effect a great service for exercising the broadest sort of control over all those operations of the Government which in any manner affect the amount of funds that Parliament will be called upon to vote for their support or the expenditure of funds when granted. In view of these large responsibilities it is a matter of great importance to determine the character of organization that this department has provided itself with in order that it may discharge them properly.

Though termed a department, the Treasury is technically a board. Prior to I7I 4 the head of the department of financial office affairs was an officer known as Lord High Treasurer. In of Treasury that year the office was put in commission; that is, while the Board 


\section{BRITISH FINANCIAL ADMINISTRATION}

office remained a single one, provision was made that its duties should be performed by a board consisting of a First Lord of the Treasury and three junior Lords. Though this board has continued in existence until the present time, all real authority has in fact passed from its hands into those of an officer known as Chancellor of the Exchequer. Thus, as President Lowell puts it, ${ }^{1}$ "by a strange process of evolution the powers of the Lord High Treasurer have, by law, become vested in a board; and by a still later custom they are actually wielded by quite a different officer, whose title indicates neither his succession to the Treasurer nor the nature of his present duties."

The position of First Lord of the Treasury is usually held by the Prime Minister, but whether this is so or not this official does not concern himself with the actual management of the affairs of the department of which he is nominally the

The Lords of the Treasury

Chancellor of Exchequer Responsible Head chief officer. The three junior Lords may have certain minor duties in connection with the Treasury, but their real duties consist in acting as assistants to the Parliamentary Secretary of the Treasury, who is often designated as the Patronage Secretary, and who is the chief whip of the Government in the House of Commons. Thus the officers nominally in charge of the Treasury in fact pay little or no attention to the direction of the affairs of that department, but concern themselves almost wholly with parliamentary matters.

The real responsible head of the Treasury is, as has been stated, the Chancellor of the Exchequer. On the parliamentary side he is assisted by a parliamentary or patronage secretary and by the three Junior Lords of the Treasury. On the administrative side, the Chancellor of the Exchequer has as his chief assistants two officers known as "Permanent Secretary to the Treasury" and "Permanent Financial Secretary." Both, as their names imply, are permanent officials. Unlike the Chancellor of the Exchequer and the Lords of the Treasury, they do not leave office when a change of ministry takes

${ }^{1}$ A. Lawrence Lowell: Government of England, vol. I, p. 8I. 
place. The former of these two officials, the permanent secretary, performs the duties of administrative head of the department; the latter, the financial secretary, has immediate charge of the duties of the department relating to the exercise of its powers of financial control over the other services. It is with the duties of this official and the organization that he possesses for their performance that we are here chiefly concerned.

To enable him to perform his duties the financial secretary has a staff composed of principal clerks, estimate clerks, and junior clerks. The several services to be controlled are grouped Staff of Financial into seven divisions with a principal clerk in charge of the affairs of each division. It is the duty of each principal clerk to familiarize himself with the organization, work, problems and financial needs of each of the services under his supervision. All matters affecting these services requiring the attention of the Treasury pass through his hands. As questions of this character are constantly arising, these officials are thus in constant touch with the services controlled by them. Sir Róbert Chalmers, the permanent secretary of the Treasury, has described the duties of these officers in the following way: ${ }^{1}$

"The Treasury consists of six [since increased to seven] divisions, each with a principal clerk at the head. Among those six [seven] divisions is distributed the work of all the departments of State; one, for instance, has the Army, the Navy and the Colonial Office; another one has the Legal Departments and the Home Office; a third has the Irish Departments, and so on, until you have distributed them all in that way among the six [seven] divisions. All the departments of State have their work distributed to a division of the Treasury, and every paper relating to a department goes to the division which has to deal with that Department of the State. Those prin-

${ }^{1}$ Report of the Select Committee on Estimates (I9I2), p. II. 
cipal clerks at the head of the six [seven] divisions are the people who consider the general question of expenditure, economy, and efficiency in the departments of State which relate to their division. Those are the real people, and they are bringing forward such matters throughout the year. ... All through the year one of the six [seven] divisions of the Treasury is considering, to the full of its time and power, all the topics belonging to the departments which fall to that division."

The estimate clerks are next in rank, and constitute the chief assistants of the principal clerks. Their duties as described by Sir Robert Chalmers, in his testimony just alluded to, are as follows: ${ }^{1}$

"The Estimate Clerk is not an officer of the highest grade with us- he is an officer of the middle grade. His function is to bring together the facts, to bring them out and to bring them before higher officers, ending with the Financial Secretary to the Treasury. It is an important office, but it is not of the highest rank. He brings in higher officers on the passage of the Estimate to the financial secretary, so far as there is anything very significant in it; but he is the man who has immediately to deal with these things and to draw attention to anything that requires attention as being large in amount or irregular in its nature."

Under the estimate clerks are the junior clerks and the general clerical and office assistants required for the conduct of any administrative office.

Treasury Use of Departmental and Interdepartmental Committees of Investigation. It is manifest that the efficiency with which the Treasiry can discharge its important duty of supervision and control over the financial affairs of the several

${ }^{1}$ Report of Committee on Estimates (1912), p. 4. 
services is dependent upon the extent to which it is in possession of detailed information regarding the organization, operations, and needs of such services. It does not appear that the Reliance on the Esprit de Treasury has put in force any scheme of reporting by which it will receive exact information regarding the operations of the services controlled. In response to inquiries by the commission, treasury officials stated that this was not necessary because the several principal clerks were in day-to-day touch with all that was going on in the services assigned to their divisions. These clerks had worked up to their position from subordinate posts. For years their duties had thus involved continuous consideration of the conditions prevailing in the services under their control. In many cases they had conducted careful investigations into conditions before recommending that treasury sanction be given to a proposed change.

In addition to the foregoing means of securing information growing out of the regular performance of their duties, the principal clerks and the Treasury as a whole have an exceedingly effective means of securing information through the use of what are known as departmental or interdepartmental committees. These are committees which are appointed to inquire into some special feature of the organization or work of a department or departments, or into the organization, work, and needs generally of a department or departments. If only one department is inquired into the committee is denominated a departmental committee. If two or more departments are involved the committee is termed an interdepartmental committee.

These committees are primarily committees created by the departments themselves for the purpose of investigating their own affairs. They are usually brought into existence when some important change in organization or work is contemplated, the head of the department desiring that the proposals shall be fully investigated and reported upon before he commits himself to their advocacy. The significant feature of this method of investigation, from the standpoint of treasury con- 


\section{BRITISH FINANCIAL ADMINISTRATION}

trol, is that on all or practically all such committees the Treasury is represented by one or more members. This representation on the part of the Treasury is welcomed by the departments concerned, since the change under consideration cannot be made until the approval of the Treasury has been obtained, and the latter will not be given until full information has been given regarding the desirability of the change.

The Treasury, however, does not necessarily wait to receive an invitation to participate in a committee investigation. If for any reason it is not thoroughly satisfied with conditions in a particular service or group of services, it itself raises the question of the appointment of a departmental or interdepartmental committee. Indeed it may be said that the Treasury pursues the policy of having the several services brought under investigation in this way at reasonably frequent intervals of time. Thus Sir Robert Chalmers, the Permanent Secretary of the Treasury, when asked the question," "Assuming that a Civil Service Department, we will say, asks for no increaseIndependent that it is a small Department, and that everybody is very happy
Inquiries and comfortable in it; and, in fact, that there is a small decrease each year, and it looks quite pretty on paper, is it anybody's duty to see that the Department is efficient, and to see that it has not twice the staff that it ought to have, for instance?" made the following reply:

"Yes. In practice the principal clerk at the head of one of the six [seven] divisions of the Treasury would be observing that Department, and would raise the question, not necessarily at the Estimates time, but at some other time he would say: 'I think we ought to have an inquiry into this'; and I should probably write privately to the head of the Department and say: 'It is some time since there was an inquiry; do not you think we had better have an inquiry by agreement at once?' We should take that as a part of our functions at the Treasury, so far as we can, to be aware of the changing circumstances from time to time, and we should try to get the Department in its

${ }^{1}$ Report of the Select Committee on Estimates, 1912, p. 7. 
organisation to conform to the position for the time being."

These committees also often come into existence when there is a difference of opinion between a department and the Treasury regarding the granting of an authorization that has been requested. If the department insists upon urging its request the Treasury will say: "We do not feel justified in approving the request until we have investigated the matter more thoroughly," and a proposal is then made that the matter be inquired into by a departmental or interdepartmental committee on which the Treasury is represented.

On the other hand the proposal for the appointment of such a committee not infrequently comes from the head of the department interested, either because he believes that if the Treasury is more fully informed regarding the needs of his service it will be more liberal in meeting demands for changes, or because he desires in this way himself to secure a better knowledge of and control over some subordinate branch of his service. In such cases he suggests privately to the Treasury that it propose an investigation. "Departments frequently ask for an inquiry rather than the Treasury calling upon them to have one. Heads of Departments find it a convenient thing for managing their more important satraps to have an inquiry at times." 1

This point of the extent to which the Treasury acts as a means for securing efficiency and economy in matters of current administration, and not merely as a body to pass upon

Ensures Economy and Efficiency applications for new expenditure, is one to which the commission gave very careful attention. In general it is inclined to believe that this attempt to secure efficiency and economy through outside control is carried about as far as is practicable. To carry it much further would introduce the danger that responsibility on the part of those actually entrusted with the conduct of Government operations would be unduly weakened. Sir Robert Chalmers, whose testimony has been repeat-

1 Testimony of Sir Robert Chalmers. Select Committee on Estimates, I9I2, p. 4. 
edly quoted, put the matter in this way. ${ }^{1}$ When asked the question, "Do you consider the supervision which is exercised by those principal clerks is sufficient for the purpose?" he replied:

"I do not think you can get any further without doing a great deal of evil. I think it is a very wrong principle of administration to supervise people too much and to remove their responsibility. I feel very strongly on that point. At the same time, I think it is very important that the Treasury should be strong enough to put each Department on its defence very frequently, so that they should know they always have to make good their case."

The Treasury as a General Organ of Administrative Control: The commission entered upon its study of the financial

A Central Business Agency of the Government system of Great Britain with a fair appreciation of the fact that to the Treasury Department was given large powers of control in respect to the formation of the estimates that were to be submitted to Parliament. Only as it prosecuted its inquiries into the details of the manner in which the Treasury exercised its powers did it come to a realization that, important as is this power of the Treasury in respect to estimates, it constituted but one feature, one manifestation, as it were, of the far broader power that the Treasury has to supervise and control, not only all matters relating to the financial operations of the Government, but practically all matters of acquiring funds and property and all matters of incurring obligations - which may be called the business functions as distinguished from the public service activities of the Government. More and more, as its investigation proceeded, the commission had borne in upon it the fact that in the Treasury the British Government had a great organ of general administrative control; that upon it fell the duty and responsibility for the final determination of what form of organization the several departments of the Government should have, what personnel was needed,

${ }^{1}$ Report of Committee on Estimates (1912), p. II. 
what compensation should be paid, what new undertakings should be authorized, what changes should be made in the employment of funds as provisionally allotted by Parliament, what new grants Parliament should be asked to make, what the works program of the Government should be, etc.; that in discharging this function it was its duty to keep itself thoroughly informed regarding the conditions and needs of the several services and use its utmost endeavor to see that the Government operations were conducted with the maximum of efficiency and economy; that, in a word, the Treasury was the one authority to which Parliament and the public looked to see that public affairs were administered in an economical and efficient manner.

The investigation also brought out another fact which the commission is sure has never been adequately appreciated by foreign students, namely, that these broad powers of the Continuous Supervision Treasury, instead of being exerted once a year when the estimates are brought under consideration, are exerted from day to day throughout the year.

Still more important, the fact was developed that not only had the Treasury this important duty of acting as a general organ of administrative control but this duty constituted practically its exclusive function. It is difficult to overestimate the importance of this fact. Until it is appreciated one totally misconceives the place of the Treasury in the British administraDetached for Controlling the Means of Doing tive system. Misled by the name, the commission began its inquiries under the impression that the British Treasury corresponded to the Treasury Department of the United States Government, that to it was entrusted, as its primary duty, the management of the national finances, the collection, custody, and disbursement of the public revenues, and that its powers in respect to the framing of estimates were, so to speak, incidental to this duty.

Nothing is further from the fact. It cannot be stated too emphatically that the British Treasury is, properly speaking, not a public service department at all. It has no public service 
Not a

Public

Service Department

duties of its own. Its functions are entirely auxiliary and controlling-restricted to looking after the financial and physical measures, and to the supervision and control of the activities of other departments. It thus stands in a class by itself as a service superior to, and in no sense coördinate with, the departments which render services direct to the public, properly speaking. In fact, it does not deal with the public; it does not collect the public revenues-this is done by the so-called "revenue" departments; it does not have the custody of the public funds-it has to secure "credits" before it has any control over such funds; it does not audit public expendituresthat is done by the Comptroller and Auditor General; it does not administer the public debt-that is performed by a separate organ, the National Debt Commissioners. It is true that these several services are often spoken of and in a way treated as subordinate services of the Treasury, but their subordination is practically the same as that of departments which perform public services. ${ }^{1}$

It is hardly necessary to point out how fundamental it is that this principle of organization should be understood by anyone who may advocate the principle of treasury control over estimates and expenditures for our own political system. It has always been a matter of difficulty for American students to understand how it was that in England one department would

${ }^{1}$ The fundamental distinction between the Treasury and the public service departments proper on the one hand, and the fiscal agencies on the other, is evidenced by the line that is constantly drawn between the Treasury on the one hand and the socalled "Spending Departments" and "Revenue Department" on the other. To the statement that the Treasury is not a public service department or spending department one serious exception must be made. For reasons which are not clear to the commission the national social insurance systems have been placed under the direct administration of the Treasury. As the result of this policy, which is wholly due to the action of the present Chancellor of the Exchequer, the Honorable Lloyd-George, the Treasury is now responsible for the expenditure of a huge and growing sum of money. This constitutes a serious break in the theory upon which the organization and functions of the Treasury rest. This departure has not escaped notice and criticism. It is very pertinently pointed out that whereas 
submit to the exercise of a control over it by another department. Any suggestion that our own Treasury Department be given powers analogous to those possessed by the British American Point of Treasury has always been met by assertions like these: That never would the other departments submit to any such supervision or control; that if the attempt were made it would break down in practice; that either the control would be of a merely nominal, and thus inefficient, character, or that constant friction would prevail. This view is so different from the experience of the average business man that we may wonder if there is, after all, something so essentially different about public business as to make the usual standards for judgment of no avail. When, however, it is found that in a great government the principles employed are those with which men of large business experience are familiar, a new hope may be entertained that citizens will in time insist that public business be efficiently managed and that the Government to that end be provided with adequate machinery for central administrative control.

Once we grasp the fundamental status of the British Treasury and the principle upon which its powers rest, all difficulty in the way of understanding why the British system works so smoothly disappears. The important fact that the United States has to learn from this is that if it has any desire or

the Treasury formerly had the duty of questioning proposals for the expenditure of money brought forward by others, it is now itself an applicant for funds on a large scale. It is thus in the anomalous position where it is its duty to question its own proposals or to let those proposals go without question. It is not merely that this is a seeming violation of the essential principles upon which the whole British system of control of estimates and expenditure rests, but it raises question as to whether it does not necessarily weaken the powers of the Treasury to control other departments. Manifestly the Treasury's powers to resist demands for funds brought forward by other departments is weakened by the fact that it is itself in the field for increased grants. This seeming mistake of policy is, however, one that can easily be corrected, and one may confidently expect the creation before long of a special department for the administration of the social insurance work of the Government. 
intention to build up in the Government a system of financial control analogous to that possessed by England it must be prepared radically to reorganize its Treasury Department as it now exists or to bring into existence an entirely new organ to perform this function. The Treasury Department of the United States as now organized is largely an administrative department.

It not only has entire charge of the collection, custody, and issue of public moneys and the management of the public finances generally; but it includes within its scope the audit of accounts-a duty which manifestly should be performed by an independent central agency. It also operates such public activities as the Revenue Cutter and Life Saving Services,

Failure of Congress to Recognize an Underlying Principle recently united in a general Coast Guard Service. The construction and operation of public buildings through the office of the Supervising Architect of the Treasury may be reconciled with central control, but not the public services. Until Congress is prepared both to accept the principle involved in having the financial affairs of the administrative services subjected to a superior supervision and control, and to provide for the creation of a proper organ through which this power shall be exercised, it will not be possible for the United States to have incorporated in its system of government that feature of the British Government which more than anything else is responsible for the efficiency and economy with which the details of Governmental operations are conducted. 


\section{CHAPTER IX}

\section{OFFICE OF WORKS AND PUBLIC BUILDINGS}

Distinction between Public Works Proper and Government Works; Government Works: Military and Naval Establishments; Government Works : Civil Services; Office of Works and Public Buildings; The Estimating and Voting of Funds for Public Buildings; Commitments; Distinction between Cost of Construction, Maintenance and Repairs, Operation, etc.; Office of Works and Public Buildings Submits Estimates for all Public Works Proper; Transfer of Funds from One Item to Another in the Works Program; Construction of Public Buildings; Renting of Buildings; Maintenance and Repair of Buildings; Supply Work of the Office of Works and Public Buildings; Powers of Office of Works and Public Buildings to Control Expenditures.

There are few features, in the system followed by a country in the voting and expending of public moneys, that are of greater interest than the policy and methods pursued in determining what public works shall be undertaken and the manner of their presentation. To the United States this is a matter of special importance on account of the magnitude of the scale on which public works are constructed and the confessedly defective system that is employed for the authorization and construction of such works. Due to this special interest in the subject the commission took especial pains to inform itself concerning how this subject was handled by the Government of England.

Distinction between Public Works Proper and Works of the Government. In considering this matter it is necessary at the outset to distinguish clearly between what may be called public works proper-that is, works intended for the use and benefit of the public generally, such as roads, river and harbor improvements, canals and the like-and works of the Govern- 
Radically

Different Questions Involved
Distinction to Be Made between Civil and Military
Lack of Parliamentary Interference ment, or those intended for the use of the Government itself, of which the most important are buildings. It is evident not only that these two classes of work are radically different in purpose and character, but that quite different policies and procedures should be followed in their authorization, financing, and, possibly, in their construction. In the United States this distinction is of especial importance on account of the extent to which the Federal Government has entered the field of public works proper. In England comparatively little is done in this way. So little does it do, in fact, that this class of public works may be almost ignored. It will be understood, therefore, that the description that follows has to do wholly with the manner in which Great Britain makes provision for the construction and operation of works required by the Government itself for the proper conduct of its work.

Works of the Government: Military and Naval Establishments. Restricting ourselves to works of this character, a second distinction should be made between works intended for the two military branches, the Army and the Navy, and those for the civil services. Following what is probably an almost universal practice, the planning and execution of works for the two military services are, in Great Britain, entrusted to these two services themselves, each maintaining for this purpose what is, in effect, a construction department. These works are not only of a very special and technical character, but also their undertaking and location are determined almost wholly by military exigencies. To an unusual degree, therefore, discretion in respect to the undertaking, the location and the character of these works should be left to the services which alone are able to determine these requirements. This, in fact, is the policy pursued by Great Britain. Not only does the initiative rest wholly with these services, but, after a decision has once been reached by the Cabinet as.regards the program as a whole, no modification of any importance is made in it by Parliament. Only in slight degree, if at all, do we 


\section{OFFICE OF WORKS AND PUBLIC BUILDINGS}

find Parliament attempting to do what the Congress of the United States habitually does, determine where naval stations, army posts, etc., shall be located, the character of the structures that shall then be erected, and even the nature of the offensive and defensive works that shall be installed.

In Great Britain, consequently, we have no such manifest evils as the location and character of military and naval posts being determined in large part by purely political considerations, and of useless posts being maintained at great cost to the public treasury and loss to the military and naval efficiency simply in response to the desires of particular Senators or Representatives that works of this character may be located in their districts. In England army and navy posts are constructed solely with reference to the needs of the services as determined by those services. It would involve us in too great Absence of Pork Barrel Legislation detail to attempt a description of the particular organization and methods employed by the war and navy departments in attending to this branch of their duties. We will therefore content ourselves with pointing out this fundamental feature of the system and devote the remainder of our attention to the system followed in planning, authorizing and constructing government works for the civil services.

Works of the Government: Civil Services. Following the policy that has been adopted throughout this report, of attempting to analyze each question taken up for consideration, in order that its full purport may be seen, a study of the problem of providing the civil services with the physical plants needed by them shows that involved in it are four important factors: ( I) The question as to by whom and how a decision shall be reached regarding what works are needed; (2) the authority or organization by which the construction work shall be performed; (3) the authority by which the subsequent work of maintenance and repairs shall be performed; and (4) the manner in which these works, representing as they do Elements of Problem capital expenditure, shall be financed. 
In meeting the first three of these points two alternative policies may be pursued, that of distributing and that of concentrating responsibility and authority. Under the first of these policies each service determines for itself what the needs are and attends to their satisfaction. Under the second, provision is made for a general public works department which has the function of acting for all of the civil service departments. It is, of course, not essential that either of these policies should be rigidly adhered to. Thus, for example, there may be a concentration of authority in respect to construction work and a diffusion of authority in respect to maintenance and repair. Under either system, of course, the individual services will take the initiative, for the most part, in making known what are their needs and desires.

The foregoing analysis has been made in order to bring out the significance of the policy that has been actually adopted by Great Britain. This policy is that of carrying the principle of concentration, both in respect of the final decision as to what works shall be undertaken and in respect of the subsequent work of construction, maintenance and repairs, to the furthest point practicable.

Office of Works and Public Buildings. This policy of concentration has been accomplished through the establishment of a public service known as the "Office of Works and Public Buildings," to which is entrusted, as far as is practicable, final authority in respect of the provision of all the civil services of the government with the buildings, grounds, and other works required by them for the proper discharge of their duties.

Organization for Centralized Control The extent of this authority may be seen from the fact that it covers not only planning and construction of buildings and their maintenance and repair, but also the decision as to whether provision for a service shall be made through the purchase or erection of a building or through the renting of a privately owned building. To this service is also entrusted the work of equipping public buildings with the necessary 


\section{OFFICE OF WORKS AND PUBLIC BUILDINGS}

office fixtures and of supplying them with the articles required for their current operation and upkeep. More specifically the duties of this office embrace:

(I) The making of estimates, the preparation of plans and the construction of public buildings for the civil services of the Government. This relates not only to buildings in London but in all parts of the United Kingdom and even in foreign countries where, as in the case of the diplomatic and consular services, buildings have to be provided. Included in the construction work under its charge are also certain miscellaneous works such as the erection of stands for public cereFunctions monies, the execution of works for the Sovereign, the Imperial College of Science and Technology, the London University and other institutions at South Kensington.

(2) The alteration, maintenance and repair of not only all the above described buildings but also all buildings used by the civil departments and all royal palaces. Included in this part of its work is the duty of maintaining, and in large part operating and controlling the use of, royal parks, pleasure gardens, ancient monuments and such institutions as the Osborne Convalescent Home for naval and military officers, the state departments at Osborne, the Brompton Cemetery, the British Museum property, etc.

(3) The renting of buildings for the civil departments, both in and outside London, where it is deemed better policy for the Government to make use of privately owned structures.

(4) The provision of all buildings used by the civil services, whether owned or rented, with the permanent equipment needed by them in the way of fixtures, carpets, furniture, etc.

(5) The supply to such services of the articles required by them for the proper operation of such buildings, such as fuel, toilet supplies, brooms, towels, etc.

The Estimating and Voting of Funds for Public Buildings. A crucial point in the public works policy of a country is the manner in which the needs of the several services of the Gov- 
System in Washington

ernment are determined and brought to the attention of the money-granting authority. In the United States, as is well known, the erection of public buildings is, in great part, undertaken at the instance of localities desiring to have public money spent and public improvements made in their districts. The desire is made known through the members of Congress representing the several districts, the means employed being the introduction of bills in Congress providing for the making of such improvements; on the basis of these several bills a general building bill is prepared and put through by the employment of the well-known log-rolling procedure. To a large extent no regard is paid to the real needs of the public service. In many cases not only are the buildings authorized not asked for by the services for whose use they are intended, but they are frequently voted against the strenuous opposition of such services. The result is a misapplication and a waste of public funds that constitute one of the scandals of American administration.

Under the British system no such wasteful expenditure of Contrast of public funds is possible. No building is authorized except upon English System the demand of the service interested. This demand, moreover, is not presented directly to Parliament, but to the Office of Works and Public Buildings, and it remains for that office to determine whether any further action shall be taken upon it. It is to this office, therefore, that Parliament looks for direction with respect to the need for public buildings and the character and cost of the structures that are required. The final determination whether a request for a building shall even be made rests with this service. If a request is made it appears as a part of the estimates of the Office of Works and Public Buildings and not as a part of the estimates of the service for which the building is intended. What the Office of Works and Public Buildings in effect says to Parliament through its estimates is: "We have carefully investigated all applications for public buildings that have been addressed to us by the several civil services of the Government, and as the result of I 88 
such investigation we recommend that the following provision be made." These estimates, of course, have to be submitted to the Treasury and are subject to its superior control as are all other estimates. The result is, thus, that each year Parliament is furnished with a works program that has been carefully elaborated by a technical service and has passed the scrutiny of the Treasury.

Commitments. A special feature of the problem of providing for public works consists in the fact that many works require a number of years for their completion. In adopting a works program a government should therefore take into consideration not only the question of new works to be authorized, but the extent to which provision has to be made for works that have been authorized in the past. This point is very carefully covered by the British system of estimating for public works. Thus the Estimates submitted to Parliament are in a form that shows clearly for each work for which an appropriation is requested, and for the works program as a whole: (I) The original estimate for the total cost of the work; (2) the revised estimate for such total cost if for any reason the original estimate has undergone revision; (3) the probable total expenditure that will be entailed to the end of the current year; (4) the amount voted for the current year; (5) the further amount required to complete the work; and

(6) the amount asked for for the ensuing year. It will thus Program be seen that Parliament is in a position where it can determine: (I) The extent to which it is already committed to expenditures for public works; (2) the extent to which these commitments will require the voting of money for the next year; (3) the extent to which it is requested to charge the Government with new commitments; and (4) the amount of money that such new commitments will call for during the year for which provision is being made.

Distinction between Cost of Construction, Maintenance and Repair, Operation, etc. The estimates furthermore distin- 
guish carefully between the expenditures for construction and those for subsequent acts in connection with the upkeep and operation of the buildings. They thus give the figures separately for: (I) New works, alteration, additions, and purchases; (2) maintenance and repairs; (3) furniture; (4) fuel, light, water, and household articles; (5) caretakers, etc.; (6) rents, tithes, net charges, insurance, etc. As regards the first three items the estimates are given for individual buildings. As regards the remaining items, the estimates are for classes of buildings, the sum so provided thus being available for expenditure at the discretion of the Office of Works and Public Buildings upon any of the buildings falling within a class. This itemization, it should be noted, is in the way of subheads of appropriations. The votes themselves are for classes of works or buildings such as "diplomatic and consular buildings," "revenue buildings," etc. ${ }^{1}$

Office of Works and Public Buildings Submits Estimates for All Public Works Proper. In addition to submitting estimates for the funds needed by it in performing work directly in its charge, the Office of Works and Public Buildings also submits the estimates for all public works proper. Thus the estimates for the year ending March 31, 1915, included estimates for: (1) Surveys of the United Kingdom; (2) Harbors under the Board of Trade; (3) Peterhead Harbor; (4) Rates on Government Property; (5) Public Works and Buildings, Ireland; and (6) Railways, Ireland. Their inclusion makes it possible for Parliament to see in one place the total cost of the works program of the Government, and thus to distinguish in a way between expenditures for capital outlay and for current operation.

Transfer of Funds from One Item to Another in the Works Program. Another feature of no little importance in the British public works system is the facility with which money

${ }^{1}$ See List of Votes, p. 76. 
allotted for one work may be applied to another. Thus, if the Office of Works and Public Buildings find, that, owing to delay in the preparation of plans or the delivery of materials, or through any other contingency, all the money appropriated for one building will not be expended during the year, and there is another building or work upon which a sum larger than the appropriation can, with advantage, be expended, it can bring the matter to the attention of the Treasury and secure a transfer. It is, of course, to be understood that the total authorized cost of a building cannot be increased in this way, nor the total sum appropriated for public buildings exceeded. This flexibility in the expenditure of moneys permits the Office of Works and Public Buildings to use to the greatest advantage the money voted. Under the American system of rigid appropriations for particular items and inability to make transfers, the construction of buildings is often delayed because the appropriations for those buildings are exhausted, while unused balances stand to the credit of other appropriations. Abuse of the large powers of discretion granted to the Office of Works in respect to the expenditure of appropriations is guarded against through the requirement that treasury sanction must be obtained for all transfers. The grant by Parliament of this power of making transfers is but another illustration of the general policy of Great Britain to grant large discretionary powers to the Executive in carrying out the general policies outlined by Parliament. This is in marked contrast with the system which prevails in the United States, where the Congress goes as far as it possibly can in the way of controlling in detail how moneys voted shall be spent.

Construction of Public Buildings. A few words should be said regarding the policy of the Office of Works in respect to the performance of the work entrusted to it. In respect to the erection of new buildings the practice of the office is to prepare the plans and supervise the work, but to have the work

Contracts under Supervision itself done by private firms under the contract system. When

English

Puts Responsibility on

Executive for Results 
the building to be erected is of special importance, however, as in the case of such buildings as the new Law Courts Building, Westminster Hall Extension, Admiralty Extension Building, new War Office, and new Public Offices Building, it is usual to call for the submission of plans from outside architects. In such cases the construction work is supervised by the Office. This is substantially the system followed by the United States.

A Controlling as Well as a Renting Agency

Usually Done by Contract

Renting of Buildings. As stated, the Office of Works and Public Buildings is the agent made use of by all the civil services in securing quarters, whether through erection, purchase or lease. A service finding itself in need of additional quarters addresses itself to this Office. The latter, on its own responsibility, can execute a lease when the rental called for does not exceed $\mathfrak{E}_{\mathrm{I} O O}$ per annum and the term does not exceed seven years. If a greater expenditure or a longer term is involved the approval of the Treasury must first be secured. In discharging this, as well as all other branches of its duties, the Office is not a mere executing agency. It is its duty, before executing a lease, to assure itself that there is a real need for the additional quarters, that the quarters are of a proper character and location and represent the most advantageous arrangement that can be made. Its function is, in other words, distinctly one of control. Responsibility for the action taken rests upon it rather than upon the petitioning service.

Maintenance and Repair of Buildings. After buildings are constructed they, as well as all rented quarters, are maintained and kept in repair by the Office of Works. In performing this branch of the work, in almost all cases use is made of the contract system. The only important exception to this is in the case of the repair of blinds of buildings in London. For some reason the Office came to the conclusion that it could do this work more satisfactorily by its own employees. It accordingly, in 1895 , organized a special shop to do this work, and its small force is permanently employed in repairing, fitting, 
and removing blinds on the public buildings of the city. For cities other than London contracts are awarded upon competitive bids to local contractors for the maintenance and repair of individual buildings or all the Government buildings in a city. The maintenance and repair of public buildings in London is provided for under a general contract covering all classes of work and running for a period of three years.

There seems to have been some question as to whether this arrangement was in all respects satisfactory. It was accordingly inquired into with considerable care by the Special ComA Critical Review of mittee on Estimates of I9I2. The committee seemed, however, to be satisfied with the explanation given by the Office of the working of the system. The Office admitted that the system as it had formerly existed was open to criticism, but maintained that the evils earlier existing had been corrected by a change made in I9II. The revised system together with the changes made by it over the old system is described in a memorandum submitted to the Committee on Estimates, from which the following is taken ${ }^{1}$

"The present triennial maintenance contract for London, held by Messrs. Leslie \& Co., Lt'd., commenced on the Ist April, I9II. In connection with this contract a new basis of tendering was adopted, the essential features of which will be best brought out by a comparison with the previously existing basis. In previous years tenders for the London Maintenance Contract had been invited on a priced schedule. This schedule was prepared by the measurers of His Majesty's Office of Works, and comprised all classes of work likely to be executed, and materials likely to be required, in the maintenance of London buildings, together with a price per unit in respect of each item of work or materials. In respect of labour in day work the tenderer was required to quote a percentage

${ }^{1}$ Report of the Select Committee on Estimates, 19I2, p. I4I. 
on the standard rates of wages which under the fair wages resolution had to be paid to the workmen. In respect of measured work and materials, the tenderer was asked to quote one percentage addition or deduction to cover every item in the schedule.

"It was thought that this method gave an unfair advantage in tendering to the existing contractors, as they alone knew the quantity of work and materials required. After prolonged consideration it was decided that the only method whereby this advantage of existing contractors could be overcome, was to prepare a schedule showing the quantities of work and material that had actually been required by the Board in one year, and to ask the tenderer himself to fill in the prices per unit. The schedule then became in reality a bill of quantities which enabled a comparison of the tenders to be easily made. The lowest tender was accepted, and the price per unit filled in by the tenderer automatically became the basis of the contract."

Furnishes All Office and Building Supplies

Evolution of the British System

Supply Work of the Office of Works and Public Buildings. As indicated in the enumeration of the duties of the Office of Works and Public Buildings, this Office is not only one for construction, maintenance, repair and equipment of public buildings but also a supply department for the furnishing of all articles required for the current operation of these buildings. The Office, in a word, stands towards all the civil services as a general supply department with respect to quarters. In a way it is the general landlord and all the several services are its tenants.

It would appear that, as regards its supply work proper, the Office originally did little more than act as a contracting agency for the other departments. Step by step, however, it has passed to the system of itself making purchases, of warehousing the articles purchased, and of issuing them to the services upon their requisition. The evolution of this system 
is thus described in a Memorandum prepared for the Commission by the Office:

"In I894 a central store was established in the Post Office Building at Clerkenwell and removed in I9OI to Lambeth Palace Road, for soap, candles and all such household requisites for the London Offices. Formerly such articles were delivered by the various contractors, who, of course, took into account the cost of distribution in making their tenders. The new system has resulted in a substantial saving and much quicker deliveries.

"In 1895 the repair, maintenance, fitting and removal of blinds for the buildings in the Board's charge was taken over by the Board's staff, instead of being done by outside contractors. The staff supervises a small body of permanent workmen. New blinds are, as before, supplied by a contractor.

"The system of supply of coal to government departments was revised in 1899-1900. An expert on coal was engaged as an assistant in the supplies division and two coal stores have been formed in London. Contracts are now made with colliery owners, the middleman being dispensed with. The arrangement has effected a very large saving and has proved most satisfactory in every respect.

"In I90I the Board took over the supply of fuel to Country Post Offices and the Prisons. In 1907 an ironmonger store was established. In 1909 an engineering store was established at Elephant Buildings, Newington Butts, S. E."

Powers of Office of Works and Public Buildings to Control Expenditures. Important as is the question of the system followed in providing the government with public buildings and in afterwards attending to their maintenance and repair, we should scarcely have felt justified in giving to it the atten- 
Has Broad Discretionary Powers

tion that we have, did the Office of Works and Public Buildings constitute a mere supply department to execute requisitions drawn upon it. As has been intimated, the functions of the office go beyond this. It is, in fact, one of the great agencies through which control is exercised over all the civil services with respect to their expenditure for quarters. It cannot be too distinctly stated that it is under no obligation to fill requisitions until it has satisfied itself that the quarters, equipment, or supplies requisitioned correspond to the needs of the service. That it has these powers and that it is its duty to exercise them is brought out by the following description of the duties of the Controller and Deputy Controller of Supplies as given in the special memorandum furnished to our commission by the Office of Works and Public Buildings:

"Controller of Supplies: Directs the general administration of the division. Decides all important questions as to supply or refusal of furniture or supplies of an unusual character; all requisitions for large or important supplies are submitted for the approval of the controller. Deals with the recommendations in connection with all important contracts. Determines the standard equipment for different classes of officers and offices. Deals personally with all important rentings of property for official purposes in London. Controls the estimates and expenditures of the division. Exercises general personal supervision over the stores, methods of purchase and distribution, workshops appointment of employees and work generally of the division. Advises the Board on all questions of policy in connection with supplies and contracts for same and labour questions arising on contracts.

"Deputy Controller of Supplies: Supervises the supply of all furniture, etc., to public buildings, deciding whether supplies are in accordance with practice or regulations and, subject to reference to the controller, what requisitions shall be complied with or refused. Advises rg6 
the Board on all less important contracts. Regulates the expenditure of the division. Reviews all cost or laboursaving commodities and devices submitted to the department before submission to the controller. Reviews specifications, etc., for store purchases and conditions of tender. Deals with all questions affecting the division in general and with questions in regard to the supply of fuel in particular, except such as are of sufficient importance to necessitate their submission to the controller. Acts for the controller in his absence." 


\section{CHAPTER $\mathrm{X}$}

\section{STATIONERY OFFICE}

The Estimating and Voting of Funds for Stationery and Printing; Allotment of Appropriations; Procedure in Purchase, Warehousing, and Issue of Supplies; Powers of Stationery Office to Control Expenditures.

In His Majesty's Stationery Office the British Government has a supply service for the furnishing of stationery and the execution of printing for the several departments, that is organized and conducted on precisely the same principles as those governing the Office of Works and Public Buildings. Unlike the latter office, however, its activities cover all the departments, military and naval as well as civil, and include stations wherever situated, outside as well as inside London.

This office came into existence as the result of Burke's Administrative Reform Act of 1782 . "Stationery before that was supplied by persons who held patents, or was bought directly by the Departments. All these patents gradually fell in, and the Departments ceased their separate purchases. The provision of stationery was undertaken by the Stationery Office, on whom further duties were subsequently laid, until the office is now a great purchasing, contracting, distributing, and selling Department, having a turnover of $£ 897,670$ and serving every other Department, and every quarter of the world." 1

The Estimating and Voting of Funds for Stationery and Printing. As in the case of the Office of Works and Public

${ }^{1}$ Report from the Select Committee on Publications and Debates' Reports, I9II, p. iii. This committee made a thorough investigation of the operations of the Stationery Office and published its findings in two reports, I9II and IgI2. 
Buildings, the Stationery Office, and not the several departments, is the authority which determines what funds shall be asked for and for which appropriations are to be made. Under the head of stationery and printing it submits in one place an estimate of the money that will be required for all branches of the Government. The several services themselves submit no estimates for stationery and printing. The character of the estimates is shown by the estimate for the year I9I4-I9I 5 precisely as it appears in the book of estimates, reproduced here on page 200.

It will be seen that though there is but a single vote the money has to be accounted for under sixteen heads. The segregation that is made has for its purpose to distinguish between: First, appropriations for the great branches of the public service, viz., (I) the administrative departments, (2) the two Houses of Parliament, (3) the Stationery Office, and Only One "Vote" (4) certain special purposes; and second, the main classes of supplies to be furnished to the administrative departments, viz,, (I) printing, (2) paper, (3) parchment and vellum, (4) binding, etc., (5) books and maps, and (6) miscellaneous small stores.

As was pointed out in our consideration of the form and character of estimates, each estimate proper, consisting of the vote and the subheads under which an accounting of the money voted is to be had, is supported by tables giving for purposes of information the details entering into each of the lettered subheads appearing in the statement that we have reproduced. Thus, for example, there is given for the subhead " $F$. Paper Supporting Details for Public Departments" the table on page 20I.

It is evidently a matter of interest to determine how expenditures for stationery and printing are distributed according to services. This is shown in a special table which gives the actual expenditure for: (I) Printing, (2) paper and other supplies, and (3) total for both items for each of 134 separate organization units during each of the years I9IO-I I, I9I I-I2 and I9I2-I3. Thus, though the appropriation for stationery

Submits All

Estimates

for

Departments 


\section{Stationery and Printing}

I. Estimate of the Amount required in the year ending $3^{\text {Ist }}$ March, 19I5, to defray the Expense of providing Stationery, Printing, Paper, Binding and Printed Books, for the Public Service; to pay the Salaries and Expenses of the Stationery Office; and for sundry Miscellaneous Services, including Reports of Parliamentary Debates.

\section{One Million and Sixty-nine Thousand Two Hundred and Seventy-Two Pounds.}

II. Subheads under which this Vote will be accounted for by the Stationery Office.

\begin{tabular}{|c|c|c|c|c|}
\hline & $1914-5$ & I913-4 & Increase & Decrease \\
\hline & & $£$ & $£$ & $£$ \\
\hline $\begin{array}{l}\text { A. Salaries, Wages, and } \\
\text { B. Horses and Carts, an }\end{array}$ & $\begin{array}{r}55,747 \\
7,200\end{array}$ & 49,983 & 5,764 & .......... \\
\hline Carts, and Carriages & $\begin{array}{r}7,200 \\
175\end{array}$ & $\begin{array}{r}9,500 \\
175\end{array}$ & & $\begin{array}{r}2,300 \\
\ldots \ldots\end{array}$ \\
\hline D. Incidental & 2,800 & 3,000 & & 200 \\
\hline E. Printing for Public Departments & 378,000 & 360,000 & 18,000 & \\
\hline $\begin{array}{l}\text { F. Paper for Public Departments. } \\
\text { G. Parchments and Vellum for Pub- }\end{array}$ & 392,000 & 423,000 & 1 & 31,000 \\
\hline lic Departments. ............... & 7,000 & 6,000 & $\mathbf{I}, 000$ & \\
\hline $\begin{array}{l}\text { H. Binding, etc., for Public De- } \\
\text { partments......... } \\
\text { I. Books and Maps for Public De- }\end{array}$ & 92,000 & 88,000 & 4,000 & \\
\hline $\begin{array}{l}\text { partments. } \\
\text { J. Miscellaneous Small Stores for }\end{array}$ & 49,000 & 49,000 & & \\
\hline Public Departments.......... & 108,000 & 105,000 & 3,000 & \\
\hline $\begin{array}{l}\text { for Two Houses of Parliament. } \\
\text { L. Printing, Paper, Binding, etc., } \\
\text { for Stationery Office Publica- }\end{array}$ & 80,000 & 80,000 & & $\bullet$ \\
\hline M. Printing, Paper, Binding, etc., & 50,000 & 50,000 & & \\
\hline N. Parliamentary Debates and & 5,800 & 6,000 & & 200 \\
\hline $\begin{array}{l}\text { Records............. } \\
\text { O. Printing, Paper, etc., for }\end{array}$ & 9,000 & 7,500 & 1,500 & \\
\hline $\begin{array}{l}\text { Bills of Entry ....... } \\
\text { entary Papers for Free }\end{array}$ & 300 & 300 & & \\
\hline Libraries............ & 250 & 250 & & $\cdots$ \\
\hline Gross Total..... & $1,237,272$ & $\mathbf{I}, 237,708$ & 33,264 & 33,700 \\
\hline $\begin{array}{l}\text { Deduct: } \\
\text { Q. Appropriations in }\end{array}$ & 168,000 & $\mathrm{I} 60,000$ & & 8,000 \\
\hline Net Total. . & $\overline{1,069,272}$ & $\overline{1,077,708}$ & 33,264 & 41,700 \\
\hline
\end{tabular}

Net decrease- $£ 8,436$ 


\section{F. Paper for Public Departments}

The provision under this subhead may be roughly classified as follows :

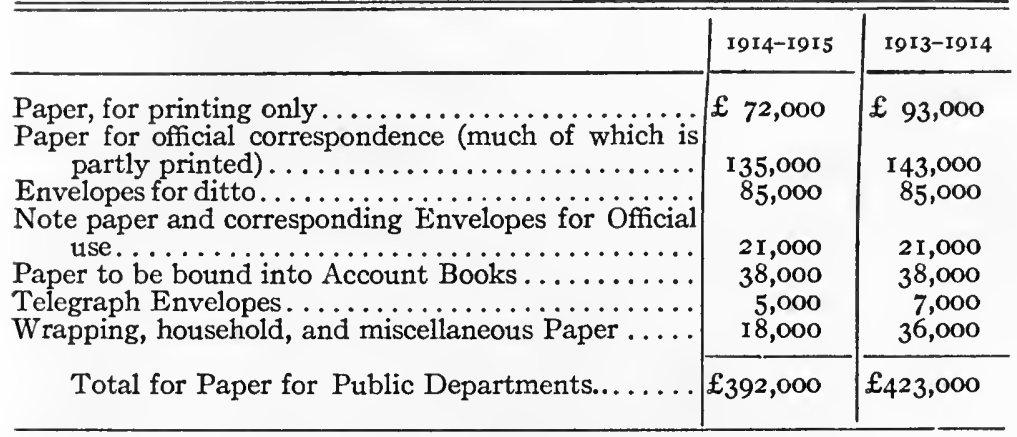

and printing is made in one lump sum and with sixteen subheads between which transfers may be made, Parliament is furnished with detailed data regarding how the money is spent by individual services.

Allotment of Appropriations. As the Stationery Office receives one lump sum for meeting the demands of all branches of the Government for printing and stationery, it is desirable that some system be devised for apportioning the money available among the several services. Until recently no attempt was made to do this, the total allotted under each subhead being generally available for all services covered by such head. Under this system there was no incentive to economy. Each service felt that any saving on its part but swelled the sum Incentives to remaining for the other services. This feature of the work Economy of the Stationery Office received careful consideration at the hands of the select committee which investigated in I I I I and 191 2 the operations of that office. In his testimony before this committee the Controller of the Stationery Office recommended strongly that the total appropriated under each subhead for the public departments be allotted to them on the basis of past expenditures, and that an allotment so made 
should not be exceeded until the approval of the Treasury had been obtained. Following this suggestion, the committee included in its report for I9I I the following recommendation : ${ }^{1}$

"Your Committee recommend that with a view to pressing upon Departments the necessity of keeping within a specific limit the expenditure for which they call upon. the Stationery Office, the sum indicated annually as the estimate for the Department in the Stationery Office Vote, should be a real estimate prepared by the Stationery Office, inclusive of all requirements, and not to be exceeded without the permission of the Treasury. At present the savings of one economical Department may go, via the Stationery Office vote, to provide the means of extravagance for another."

Recommendations of Committee Accepted
Order of Treasury Governing

This recommendation was accepted by the Treasury in so far as the items assigned for printing and publications were concerned, but was rejected as regards stationery items. In the Treasury Minute dated February 22, I912, through which it put into effect most of the recommendations of the committee, it stated as follows: ${ }^{2}$

"Expenditure on Stationery and Printing is of such a nature that it is peculiarly difficult for the Department on whose vote the expenditure falls (the Stationery Office) to exercise effective control over the demands of other Departments, and it must mainly rest with the Departments themselves to effect the economies (the possibility of which My Lords do not question) by reduction of demands for Paper, Printing and other Stationery. . . . As regards the supply of Paper and other articles, My Lords think economy would best be served by the sug-

${ }^{1}$ Report from the Select Committee on Publications and Debates' Reports, I9II, p. v.

${ }^{2}$ Report from the Select Committee on Publications and Debates' . Reports, 1912, Appendix No. 1, p. 67. 
gestions approved above for departmental control of demands, and for inspection, standardisation, etc., and that if these are acted upon it will not be necessary to require Treasury authority for expenditure in excess of a necessarily somewhat conjectural estimate.

"On the other hand, as regards cost of Printing, My Lords think that the suggestion of the Select Committee should prove of service in directing the attention of Departments to their Printing expenditure in years in which this expenditure is exceptionally heavy. They are therefore giving directions to the Controller of the Stationery Office to prepare an Estimate based on the expenditure on Printing for various Departments in previous years (as shown in the Stationery Office Estimates), and They propose to adopt that Estimate as the limit of Printing expenditure for each Department for each financial year, beyond which any new expenditure would require their Lordships' sanction."

The result of this action on the part of the Treasury was to establish the allotment system for the item of printing, but not for that of stationery. To control expenditures under Allotment System for Printing the latter head, the Treasury adopted recommendations of the Only Committee :

That demands for Stationery and Printing in each Department should be under the direct charge of an officer of sufficient status and that he should work under the direct supervision of an officer of the highest rank (i.e., not below the rank of Assistant Secretary or its equivalent) who should countersign the demands; that the Stationery store of each Department should be periodically inspected by the Stationery Office; that a list of ordinary consumable stores be compiled by the Stationery Office, and that supplies of articles not on the list be only allowed on cause being shown; that standardising of ar- 
ticles supplied be encouraged, and that "touting" by outside firms be forbidden.

Procedure in Purchase, Warehousing and Issue of Supplies. The Stationery Office kindly prepared for the commission a statement describing the practice and procedure followed by it in the discharge of its duties. From this statement the following is taken as covering some of the most important aspects of its work : ${ }^{1}$

Purchase of Supplies: " $\mathrm{Up}_{\mathrm{p}}$ to the present the government owns no mills or printing works, although a proposal to establish a state printing office is now under consideration. Supplies are therefore obtained under contracts made by the Controller of Her Majesty's Stationery Office with suitable firms. All important contracts are put up to open competition and are widely advertised; in the case of smaller items required specially, a limited tender is issued to those firms known to be in a position to supply satisfactorily. As a general rule the lowest tender is accepted.

Inspection: "Everything supplied is carefully examined at His Majesty's Stationery Office to see that it is strictly in accordance with the specification. In every branch of the department where technical knowledge and experience are of value the Controller has at his disposal a staff of experts, chosen by special competitive examination in the subjects appertaining to the particular branch. Also, when advisable, the accounts rendered by the various firms employed are checked by officers of technical experience.

Standardization: "It may be noted that, so far as possible, supplies made for the public service are standardised, departments being informed of the desirability of

${ }^{1}$ In some cases side headings have been inserted. 
coöperation in this respect. It is found that by this means more favorable terms can be obtained in buying.

Marking: "Wherever practicable a government mark is placed upon all articles supplied by His Majesty's Stationery Office as a safeguard against their improper use.

Storage: "As far as space allows, a stock equal to six months' supply is kept by His Majesty's Stationery Office of all articles for which there is a regular demand, saving only perishable material, such as printing paper, which is ordered as required under running contracts. No store is kept of articles for which there is only an occasional demand, the government departments requiring them holding their own stock. The same arrangement applies to printed forms, other than official publications (which will be dealt with under a separate heading), His Majesty's Stationery Office, in this case, protecting itself against having to pay fresh charges for composition when the forms are reprinted by inserting a clause in the contracts that the type shall be kept standing for a specified period.

Issue of Supplies: "Departments are expected to demand supplies equal to about six months' consumption to obviate the economic disadvantage of purchasing small quantities. The distribution of printing and stationery is arranged through the medium of clerks of stationery in the various government departments. Requisitions are made by these officials on special forms issued by His Majesty's Stationery Office, which, with certain exceptions to be specified, are sent to that department. As a guarantee that the articles demanded are necessary for the work of the department, each form must be countersigned by an official of superior rank.

Direct Purchases: "The privilege of direct communication with contractors is allowed to certain departments 


\section{BRITISH FINANCIAL ADMINISTRATION}

whose work involves specially urgent or confidential printing. Special forms of demand are issued, on receipt of which the contractor will execute the work required, the demands being afterwards forwarded to His $\mathrm{Maj}$ esty's Stationery Office for the issue of covering orders to the contractor and for purposes of account. It is of course understood that the use of these forms is restricted to cases of absolute necessity.

Official List of Articles Furnished: "Lists of articles authorised by His Majesty's Treasury for use in the public service are issued to the clerks of stationery, and articles not on the approved list are only supplied to departments that have special need of them. In the case of printed matter a small pamphlet is issued for the purpose of instructing the departments how 'copy' may be prepared in a form which can be most economically printed.

Allotment of Funds for Printing to the Several Departments: "Also the printing for each department of the service is restricted to an annual allowance based on the expenditure of previous years and the estimate requirement of the department concerned. A record is kept and the allowance may not be exceeded without treasury sanction being first obtained.

Control by Stationery Office: "On receipt at His $\mathrm{Maj}$ esty's Stationery Office the demands pass through the hands of technical experts, who scrutinise them most carefully with a view to effecting economies in quality of paper, printing, etc. Attention is also given to the requisitions with the object of checking extravagance.

Delivery: "As regards the actual issue of the articles, departments in the London district are served by motor vans belonging to His Majesty's Stationery Office; outside this area advantage is taken of the cheapest available 206 
means of transit, the cost being borne on the vote of the department to which the supply is made. In the case of large quantities of one article required for a particular service, arrangements are sometimes made for direct delivery by the contractor, samples from the supply being sent to His Majesty's Stationery Office for examination. Paper required by printing and binding contractors is issued to them in bulk, the contractor being required to render an exact account of its consumption.

Printing and Distribution of Public Documents: "His Majesty's Stationery Office is responsible for the printing and distribution of all official government publications in the United Kingdom. These are divided into two classes: (a) Parliamentary Papers, which include bills and acts of Parliament, papers presented to both Houses by command of His Majesty, and papers ordered printed by either House. (b) Stationery Office Publications, which comprise all the official publications issued by His Majesty's Stationery Office for sale to the public other than those included under 'a.' A stock of these publications, sufficient to meet the requirements of the public departments, is held at His Majesty's Stationery Office, arrangement for sales to the public being in the hands of contractors, who pay a certain premium for the right of holding the contract. There are a few exceptions to this arrangement, while in Scotland, His Majesty's Stationery Office has recently, by way of experiment, dispensed with the services of an agent and is now selling direct to the public.

Waste: "The disposal of waste paper is also carried out under contract, the contractor paying a certain sum to His Majesty's Office for the privilege."

Powers of Stationery Office to Control Expenditures. Though the powers of the Stationery Office to control the ex- 


\section{BRITISH FINANCIAL ADMINISTRATION}

penditures of the several services by questioning and revising their requisitions are not so clear as in the case of the Office of Works and Public Buildings, the commission was informed that the Stationery Office did, in fact, carefully scrutinize all requisitions made upon it, for the purpose of determining whether a real need existed for the articles requisitioned and whether a cheaper grade of articles than the ones asked for would not suffice. It would appear that this control is much stricter in regard to printing and the supply of forms than is the case with respect to paper and ordinary stationery supplies. We thus read in the report of the Select Committee on Publications and Debates Reports: ${ }^{1}$

"As the result of the recommendations of previous Committees, Departments increasingly consult the Stationery Office before work is carried out. A Revising Branch of that Office was established in 1907, through which control is exercised over the requisitions of Departments; and it is estimated that a saving has been effected by its action, during the four years of its existence, of

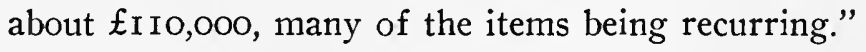

1 IgI I, p. v. 


\section{CHAPTER XI}

\section{THE AUDIT OF PUBLIC ACCOUNTS}

History of Development of the Present Audit System; Status of the Comptroller and Auditor General; The Method of Keeping and Rendering of Accounts Prescribed by the Treasury; Audit of Public Accounts; Powers of Comptroller and Auditor General in Respect to Disallowance of Items; Duty of Comptroller and Auditor General in Respect to the Control of Unwise or Extravagant Expenditures; Standing Committee of Public Accounts of the House of Commons.

More than once allusion has been made to the remarkable fact that though almost from the beginning of constitutional government in England the theory has been held that the conConstitutional Significance of Audit trol of the public purse lay in the House of Commons, that body failed, until a very recent date, to develop the means through which that control might in fact be made effective. We have traced the development of certain of these means in our account of the rise of an appropriation system and the requirement that the Executive shall keep and render to the House accurate reports regarding the manner in which the funds granted to it are expended.

Important as these means are, they evidently fail fully to meet the requirements of complete control unless they are supplemented by some system by which the House may subject these accounts to an inspection with a view to determining whether they in fact represent a real carrying out of the conditions imposed in making the grants. "I have always been greatly struck," declares Lord Welby in his testimony before ,the Select Committee on National Expenditures, "' "by the fact that for, you may say, a hundred and sixty years, the

${ }^{1}$ Report, 1902, p. 175 . 
House of Commons, always anxious to establish its control, should have remained all that time under the illusion that it could control expenditure by putting checks upon the issue of money from the Exchequer instead of ascertaining how the money had been spent. It is most singular that all the able men who represented the House of Commons during that time should have remained under that illusion." "The fact is," he elsewhere stated," "that Chancellors of the Exchequer, their advisers, and Parliament itself were still under the illusion that Parliamentary control over expenditure could be effectively secured by safeguards on the issue of money from the Exchequer without following the expenditure further."

History of Development of the Present Audit System. Obvious as this fact now is, it was not until the middle of the nineteenth century that it was fully realized or at least until then no adequate means were provided for an audit. The idea of an examination of some accounts, and some attempt to put this idea into execution, it is true, can be found in earlier years. "There was, indeed," writes Lord Welby in his Memorandum on the Control of the House of Commons over the Public Expenditure, ${ }^{2}$ "an audit conducted by officers of the Exchequer under regulations framed for the times of the Tudors and Stuarts. It was left unaltered at the Revolution of $\mathrm{I} 688$,

Methods Employed in the r 1 th and the 18 th Centuries and for nearly a century afterwards. It limped leisurely along, so much so that in 1782 great accounts twenty and thirty years old were still open, and there were accounts not yet settled which went back to the reign of William III. But this limping audit was not an audit for Parliament. The accounts when audited were not submitted to Parliament; they were declared before and passed by the Treasury, and the authority of the Treasury in passing them was unquestioned."

The great defect in this system was not merely that the ex-

\footnotetext{
${ }^{i}$ Report of Committee on National Expenditure, I902, p. 229.

${ }^{2}$ Report of Committee on National Expenditure, 1902, Appendix No. I3, p. 228.
} 
amination of accounts was made in a dilatory and inefficient way, but that this examination was made by the branch of the Government responsible for making the expenditures.

Defects in System

"Here was the great blot of our financial system. Defects in the Estimates and in the method of voting them were gradually removed, but the chief defect of all, that the House of Commons did not know how its grants had been expended, remained unremedied until the Exchequer and Audit Act came into force. It is singular that two of our greatest Chancellors of the Exchequer, Mr. Pitt and Sir Robert Peel, did not seize the point. It is the more singular as regards Mr. Pitt, because he reformed the system of audit, he swept away the old audit by Officers of the Exchequer and transferred the duty to a new authority, the Board of Audit, which he endowed with considerable powers. The audit applied by the new Board was effective as far as it went, and prompt as compared with that of the Exchequer Officers, but he made no provision for laying the results of the audit before the House of Commons. The Treasury passed the audited accounts, it owed no responsibility to Parliament in respect to them, and remained, as under the previous system, master of the situation." 1

A great opportunity to correct this defect was presented in 1834 when the old Exchequer was abolished and provision was made for a new officer known as Comptroller of the Exchequer, who was to have control over the custody of public funds and whose authorization was required before any moneys could be drawn from the Treasury. In the creation of this office the idea of Parliament was to protect the Treasury by controlling issues from the Treasury for expenditure purposes. The Develcpment of the Present System These issues were simply advances of large sums to disbursing officers as authorized by appropriation acts; they were not expenditures proper.

${ }^{1}$ Lord Welby Memorandum, etc., p. 228. 
The credit of developing and having adopted the modern principle of control through an examination of the expenditures themselves Lord Welby ascribes primarily to Sir James Graham, who became first Lord of the Admiralty in 1831 , and the Public Monies Committee of $1856-7$.

"In I83I that most able administrator, Sir James Graham, became First Lord of the Admiralty. He found the civil branches of that department organised as they had been organised in the time of Elizabeth. He left them organised on the principle that has worked, and worked well, to the present day. Sir James Graham's speech in moving the Navy Estimates of I83I is of historical interest. In the course of it he said that he and

Statement by Lord Welby Mr. Hume in 1829 and 1830 , when calling attention to the Navy Estimates, "had too much neglected the details of the Estimates in their anxiety to effect a tangible reduction of the general sums of the Votes. Had they not been so much occupied in pointing out savings, they would have effected much benefit in investigating how far the actual expenditure under each head squared with each Estimate. The only remedy which he saw then was to lay before the House annually a balance sheet, in which would be specifically placed under each head the actual expenditure of the Navy and Victualing Boards.' Parliament in consequence, and at his instance, passed an Act requiring the Admiralty annually to present such an account to the House of Commons. This account, called the Navy Appropriation Account, has been annually presented up to the present time. It is based on the audited account of naval expenditure, and it shows the actual expenditure, as ascertained by the auditor, under each head of service. The precedent thus created was applied in later years to other great divisions of the public expenditure, and has formed the model on which the Appropriation Accounts of public expenditure are now ren- 


\section{THE AUDIT OF PUBLIC ACCOUNTS}

dered. It is the first instance, as far as I am aware, in which a minister grasped the importance, I might say the necessity, of laying before the House of Commons a return of actual expenditure; but it was an isolated instance, applying to only one branch of expenditure, and there being no provision in the Act which forced the House of Commons to pass a judgment on the Account, it practically passed year by year without the notice which it deserved." 1

Though the precedent thus established of having an audited statement of actual expenditures laid before Parliament annually was gradually extended to certain other services, and

Further Steps in the Evolution notably to the War and Ordnance Offices in I846, the next step of real importance was not taken until twenty-five years later. This step consisted in the appointment in 1856 , and the report in 1857 , of the able committee of the House of Commons on the receipt, issue and audit of public moneys in the Exchequer, the Pay Office and the Audit Department. Regarding this committee, which is usually known by the name of the Public Monies Committee of 1856-7, Lord Welby, in his testimony before the Committee on National Expenditures, I902, said : ${ }^{2}$

"It was only very gradually that the change $[i . e$., to the modern system of audit] took place. That change is marked by that very remarkable Committee of $1856-7$, the Public Monies Committee, which is, I think, one of the most remarkable Committees, both as regards its constitution and the work it did, that I remember. The Public Monies Committee knocked on the head once for all the idea that any effective control could be exercised by watching the issue of money from the Exchequer and showed that the real control of Parliament must be by

1 Lord Welby Memorandum, etc., p. 229.

${ }^{2}$ Report, p. 175 . 
ascertaining, through independent officers of its own, how the money had been spent."

This committee made a number of recommendations cover-

Recommendation of the Public Monies Committee
Advocacy of an Independent Board or Office Responsible to

Parliament ing a wide range of topics, many of which were approved by Parliament and incorporated into law. Indeed, it is not too much to say that this report laid the basis for the whole modern system of financial management and control. We shall have occasion in other places to speak of a number of these recommendations. In respect to the particular subject under consideration, it recommended in the strongest terms possible the extension of the principle of laying before Parliament annual statements of audited expenditures of all branches of the public service. Furthermore, it brought out, in a way that had never been done before, the imperative necessity that this audit and report should be made by officers of Parliament itself responsible only to that body for the manner in which they performed their duties. The report thus said: ${ }^{1}$

"The concurrent audit or appropriation check first applied to the expenditure of the grants for naval services in 1832 , and subsequently extended to the several Army grants, was a new security introduced for ensuring, the strict appropriation of the grants of Parliament. It was not intended to limit the discretion of the responsible Departments of the Executive Government in which it was established, but to secure a revision of their accounts by an independent authority, invested with sufficient power of investigation to detect any misapplication of the Votes, or any deviation from the appropriations sanctioned by Parliament. This check now applies to the Naval and Military expenditure, and is regulated by the provisions of an Act passed in 1846 , also to the expenditure of the Offices of Woods and Forests, and Public Works, and the Commissioners of Audit transmit annually to the Treasury, for presentation to the House of ${ }^{1}$ See Report of Committee on National Expenditure, 1902, p. 229. 


\section{THE AUDIT OF PUBLIC ACCOUNTS}

Commons, accounts of Naval and Military expenditure compared with the grants, accompanied by reports in which they direct attention to every departure from the provisions of the Appropriation Act. Your Committee recommend that this important check upon the application of the public money be extended to the accounts of the income and expenditure kept at the Treasury, to the accounts of the Revenue Departments, and to the various accounts comprising the expenditure of the Votes for Civil Services, including Civil Contingencies. . . Y Your Committee are also of opinion that the whole of these accounts, finally audited, should be presented to Parliament before the close of the year succeeding that to which they relate. ...

". . . Your Committee suggest that the Audit Board should no longer transmit through the Treasury those accounts which they are bound to lay before Parliament, but should communicate them direct, and that the appropriation and inspection of Army and Navy Accounts, the selection of officers for the respective duties, their removal or dismissal should rest entirely with the Audit Board.

"Your Committee have recommended a large extension of the duties and powers of the Board of Audit. If these suggestions be adopted it will be necessary that the composition and relative position of this Board, as a great department of State, should be reconsidered by the Executive Government. The Board of Audit is responsible to Parliament alone, and the station and emoluments of the person at the head of it should be equal to the importance of the duties to be performed, and not second in rank to any of the permanent officers presiding over other principal departments."

Though action did not immediately follow this report, it, as Lord Welby expresses it, "practically decided the form in 


\section{BRITISH FINANCIAL ADMINISTRATION}

The Idea

Established by Standing Orders

Exchequer and Audit Act of 1866

The

Exchequer under Control of Parliament

which parliamentary control over expenditures should be established." The two great recommendations of the committee-that provision should be made for a standing committee of the House of Commons, to whom all audited accounts should be referred for consideration and report, and that all accounts of the Government should be audited by an officer directly representing Parliament and independent of the Crown-were adopted, the one in I86I through a standing order to that effect, and the other in I866 through the passage of the famous Exchequer and Audit Departments Act ( I866). ${ }^{1}$

The passage of this act marks almost the final stage in the evolution of the present system of public expenditures. It stands on the statute books in almost the same form in which it was originally enacted, such amendments as have been made to it covering little more than matters of detail. "The House of Commons," to quote Lord Welby again, "learned at last that it could not insure correct appropriation by cumbrous checks imposed before the expenditure took place, and that it could only enforce its control by early audit of the expenditure after it had taken place and by examining itself the results of that audit."

Status of the Comptroller and Auditor General. To understand the status and functions of the Comptroller and Auditor General one must start with an appreciation of the fact that the public funds technically are neither in the possession nor under the control of the Crown. Legally such possession and control are in Parliament. The latter merely grants authority to draw upon these funds for certain designated purposes and in certain specified amounts. It is the function of the Comptroller and Auditor General, acting as the direct representative and officer of Parliament, to see that no funds are drawn from the Exchequer except in pursuance of authority given by Parliament, and that such funds as are drawn are applied

${ }^{2} 29$ and 30 Vict., c. 39. 


\section{THE AUDIT OF PUBLIC ACCOUNTS}

only to the specific purposes and in the way ordered by that body.

The great reform from the auditing standpoint that was accomplished by the act of I 866 was not only the provision that all accounts of the Government should be audited, but also that this audit should be by an officer of Parliament making report directly to it. That this theory of the status of the Comptroller and Auditor General might be fully carried out in practice, it was necessary to give to this officer such a position as would render him independent of the executive the acts of which it was his duty to control. This was secured by the provisions that, though the Comptroller and Auditor General is appointed by the Crown, he holds office during good behavior and can be removed only on an address from the two Houses of Parliament; and that his salary constitutes a permanent charge upon the Consolidated Fund. The same provisions which are employed to secure the independence of judges were thus applied to him.

In making this statement it is necessary, however, to distinguish between the personal independence of the Comptroller and Auditor General and that of the office held by him. All that the provision given above accomplishes is to ensure that the Comptroller and Auditor General shall be in a position where he can exercise such authority as is conferred upon him with perfect independence of the Crown. When we come to consider the scope of his authority, and especially the powers that he possesses to determine accounting procedure, on matters such as the organization and personnel of even his own office, we encounter the rather remarkable fact that final authority rests not in his hands, but in those of the Treasury. The Exchequer and Audit Departments Act thus provides that "the Treasury shall from time to time appoint the officers, clerks and other persons in the department of the Comptroller and Auditor General"; that "Her Majesty by Order in Council may from time to time regulate the numbers and salaries of the respective grades or classes into which the said officers,

The
Auditor

General

an Officer of

Parliament

Wholly

Independent of Executive trative Law 
The Office Kept "Out of Politics"

Prescribed by the Treasury

Regulations of Auditor General

clerks and others shall be divided"; that the Comptroller and Auditor General may have power to frame orders and regulations for the internal business of his department, but that such orders shall not be issued nor have validity until "all such orders and forms shall be approved by the Treasury."

The Method of Keeping and Rendering of Accounts Prescribed by the Treasury. Strictly in line with this theory of preserving the administrative authority of the Treasury over the management of the public finances is the provision that the Treasury, and not the Comptroller and Auditor General, shall be the authority to determine the manner in which all public accounts shall be kept and rendered. The act thus reads: "The Treasury shall determine by what departments such accounts [i.e., appropriation accounts] shall be prepared and rendered to the Comptroller and Auditor General"; that "a plan of account books and accounts, adapted to the requirements of each service in order to exhibit in a convenient form the whole of the receipts and payments in respect of each vote, shall be designated under the supervision of the Treasury, and Her Majesty may, from time to time, by Order in Council, prescribe the manner in which each department shall keep its accounts"; that any official receiving public moneys "shall at such time and in such form as the Treasury shall determine render an account of his receipts and payments to the Comptroller and Auditor General"; and that, though the Comptroller and Auditor General may prepare regulations setting forth the time and form in which accountants shall submit their accounts with supporting authorizations and vouchers, "no such regulations shall be obligatory on such accountants until they shall have been approved by the Treasury."

The foregoing represents a reproduction of only a few of the more significant clauses of the Exchequer and Audit Departments Act bearing upon the matter of the prescribing of. the methods to be followed by the several services of the Government in keeping and rendering their accounts. All through 


\section{THE AUDIT OF PUBLIC ACCOUNTS}

the act, however, constant reference is made either to the power of the Treasury itself to direct how this or that feature of the accounting system shall be managed, or to the requirement that the approval of that department shall be had before regulations otherwise formulated shall have validity.

Audit of Public Accounts. A description has already been given of the duties of the Comptroller and Auditor General as a comptroller of Exchequer issues. We hâve now to consider the duties of this officer as an auditor general. In this capacity, Parliament, by the Exchequer and Audit Departments Act and other acts, has imposed upon the Comptroller and Auditor General the duty of examining and auditing all or practically all the accounts of the Government, whether these accounts relate to general revenues and expenditures or to the financial operations of special institutions such as arsenals, hospitals, etc. In some cases the audit required is a detailed one involving the examination of every item of expenditure with a view to determining whether it is in accordance with law, has been properly authorized, is supported by proper vouchers, etc. In other cases the examination represents only what is known as a "test audit," that is, an audit of a certain class of Procedure of Audit expenditures, or expenditures during a particular brief period. Test audits of this kind are thus made of store accounts, manufacturing and expense accounts of the Army and Navy, manufacturing establishments, etc.

It is manifestly impracticable to attempt in this place to enter into any detailed consideration of the procedure employed in conducting these different audits. Our interest is directed only to that feature of the work of the Comptroller and Auditor General which bears directly upon the great problem of securing control over the expenditures generally. We have seen that expenditures fall into two great categories: Those represented by Consolidated Fund services, and those represented by the supply services. The audit of expenditures of the first class is a comparatively simple matter, and requires 
Audit Expenditures of Supply Services

no special comment. It remains, therefore, for us to consider only the work of the Comptroller and Auditor General in auditing the expenditures provided for by the supply services. ${ }^{1}$

As has been pointed out, appropriations are made for the supply services in the form of votes, and designation is made in the estimates of the subheads under which each vote must be accounted for. For each vote an official of the department to which the vote relates is designated by the Treasury as "accounting officer" with the duty of controlling and rendering an account of its expenditures. This account is rendered to the Comptroller and Auditor General. Each vote is the subject matter of a separate account. There are thus as many accounts as there are votes. These accounts constitute the socalled "appropriation accounts," which as audited are laid before Parliament by the Comptroller and Auditor General. It will be noted that each vote is treated as a financial entity, and the account must cover the receipt as well as the expenditure side of the vote. This is a matter of importance, since as the result of the system of appropriations in aid many votes are credited with important receipts. As described by the official pamphlet, "Control and Audit of Public Receipts and Expenditures," 2 this account is designed to show, under the several subheads, "the amount granted by Parliament for the service, as detailed in the estimate, the expenditure compared with the grant, the appropriations in aid estimated and realised, the surplus or deficit under each subhead of the vote, with an accompanying explanation of the causes which led thereto, the total

${ }^{1}$ Students desiring to study more in detail the accounting and auditing methods of the English Government should consult: (I) The Exchequer and Audit Departments Act (I866), a copy of which is appended to this report; (2) the pamphlet "Control and Audit of Public Receipts and Expenditures" issued by the English Government in 1907; and (3) the pamphlet "General Instructions for Guidance in the Examination of Accounts in the Exchequer and Audit Department," Seventh Edition (Oct. I, I9II). These are not public documents in the ordinary sense, but copies can probably be secured by addressing the Comptroller and Auditor General.

${ }^{2}$ P. I4. 


\section{THE AUDIT OF PUBLIC ACCOUNTS}

surpluses to be surrendered to the Exchequer, or the deficit to be voted and the amount of extra receipts received and paid over to the Exchequer."

The Exchequer and Audit Departments Act provides that these accounts shall be rendered to the Comptroller and Auditor General on or before December 31 in the case of the army vote, and on or before November 30 in the case of the other votes; that they shall be audited by the Comptroller and Auditor, General and transmitted to the Treasury not later than January $3 \mathrm{I}$ in the case of the army vote, or January I 5 in the case of the other votes; and that the Treasury shall transmit them to the House of Commons not later than February 15 and January 3 I respectively. If Parliament is not sitting on those dates the audited accounts must be transmitted within one week after it assembles. It follows then that Parliament, almost immediately upon assembling and before it has received the estimates for the year to come, has laid before it an audited statement of the manner in which the votes for the year preceding the current one have been expended.

It is evident that in order to secure this prompt rendition of an audited account of expenditures, the work of audit must not be postponed until the account is rendered. The Exchequer and Audit Departments Act thus provides that "in order that such examination may, as far as possible, proceed pari passu Audit Continuous with the cash transactions of the several accounting departments, the Comptroller and Auditor General shall have free access, at all convenient times, to the books of account and other documents relating to the accounts of such departments, and may require the several departments concerned to furnish him from time to time, or at regular periods, with accounts of the cash transactions of such departments respectively up to such times or periods." 1

Powers of Comptroller and Auditor General with Respect to Disallowance of Items. To students familiar with the audit-

${ }^{1}$ Sec. 28. 
No Power of Disallowance, Only of Examination and Report

Does not Interfere with Executive Responsibility

Rule Governing Settlements

ing system of the United States Government it will probably come as a matter of surprise that the powers of the English Comptroller and Auditor General in auditing public accounts are confined strictly to those of examination and report and. that he has no power finally to disallow an item of expenditure which in his opinion has been improperly made. Under the American system it is of the essence of the powers of the auditor in settling an account to "suspend" all items which appear to represent an improper payment or one for which a proper voucher or other authority is not produced; and if a satisfactory explanation is not then forthcoming finally to "disallow" such items. This means that the officer rendering the account will receive no credit for such payment, and thus he or his bondsmen must make good the amount by securing, if possible, a repayment on the part of the person to whom the money was paid, by making good the amount out of his own funds, or by seeking a relief from the liability through an act of Congress.

Under the English system the Comptroller and Auditor General, as stated, has no such powers to disallow an item. All that he can do is to bring the matter to the attention of the Treasury for determination as to what action shall be taken. It is certainly a remarkable fact that this latter authority apparently has full power to waive any irregularity and to use its free discretion as to whether an item shall or shall not be allowed. It thus exercises a power which under the American system can only be exercised by Congress itself. That this is the law appears from the following provisions of the Exchequer and Audit Departments Act relative to this matter:

"If during the progress of the examination by the Comptroller and Auditor General hereinbefore directed any objection should arise to any item to be introduced into the appropriation account of any grant, such objection shall, notwithstanding such account shall not have been rendered to him, be immediately communicated by 
him to the department concerned, and if the objections should not be answered to his satisfaction by such department, they shall be referred by him to the Treasury, and the Treasury shall determine in what manner the items in question shall be entered in the annual appropriation account." 1

"In all cases in which an accountant may be dissatisfied with any disallowance or charge in his accounts made by the Comptroller and Auditor General such accountant shall have a right of appeal to the Treasury, who, after such further investigation as they may consider equitable, whether by viva voce examination or otherwise, may make such order directing the relief of the appellant wholly or in part from the disallowance or charge in question, as shall appear to them to be just and reasonable, and the Comptroller and Auditor General shall govern himself accordingly." 2

The vesting of this power to allow or disallow items in the Treasury is but another illustration of the fact that Parliament in providing for an audit of expenditure by its own officer was yet careful to retain intact the general principle that No Division of Authority the Treasury is the organ upon which rests the general responsibility for the manner in which the finances of the nation are administered. No one can read the provisions of the Exchequer and Audit Departments Act without being impressed with the strength of the feeling that financial responsibility should not be weakened by distributing control between two authorities.

Duty of Comptroller and Auditor General in Respect to the Control of Unwise or Extravagant Expenditures. There has always been a difference of opinion on the part of students of financial administration as to whether the functions of an auditor or comptroller should be restricted to those of a mere

${ }^{1}$ Sec. $3 \mathrm{I}$.

${ }^{2}$ Sec. 43 . 
examination of accounts with a view to ensuring that the laws and regulations governing the expenditure of funds have been complied with, or whether he should have the larger responsibility of seeing that funds voted are applied in the most economical and efficient manner possible. For example, cases frequently arise where one service will pay a higher price for an article or service than is paid by another service, or where the accounts will reveal that one service will make use of much Control more expensive articles than are used by other services for over. Questions of Economy precisely the same purpose. In all these and many other analogous cases where expenditures are made which are not justified by the real needs of the service making them, the question arises whether it is the duty of the auditor to question and if need be disallow the items representing such expenditures, even though the technical accounting requirements are met.

Generally speaking, it may be said that in the United States, or at least in the Federal Government of the United States, auditors have no such function or powers. The furthest that they may go is, in extreme cases, to call the matter to the attention of the spending department and suggest a change of practice in the future. A reading of the report of the Committee on National Expenditure (I9O2) indicates that in England a feeling exists that the duties of the Comptroller and Auditor General should go further than this; that upon him rests, in some degree at least, responsibility for checking unwise or extravagant expenditures. Thus we find the clerk in charge of estimates in the Treasury in his testimony before the committee giving the following replies to questions put to him regarding this matter $\mathbf{~}^{1}$

Auditor

General's

View of His

Powers
"Is not the examination by the Comptroller and Auditor General rather one in respect to form, and audit, and regularity, than in respect of the merit of the expenditure? The Comptroller and Auditor General frequently

${ }^{1}$ Report, pp. 2-3. 
reports to the Public Accounts Committee cases in which he thinks that value has not been received for money.

"Would the Comptroller and Auditor General go so far as to say that he considered this or that establishment [i.e., staff and force of clerks] excessive? Not if it had been sanctioned by the Treasury.

"The point I want to get at is this: Assume as a hypothetical case that there is a Department where extravagance is going on, where the establishment is excessive, or where too much money is being spent, who would discover that and stop it? If the establishment is excessive the Treasury must discover that for itself; but the other kind of extravagance, that of buying goods, for instance, at excessive prices, would, I think, very probably be discovered by the Comptroller and Auditor General.

"Is that distinctly within his attributions? He certainly calls attention to cases, for instance, where an article has been bought by the War Office or Admiralty at one price, and another article of much the same character has been bought at a different price. He calls attention to cases of that kind as indicating that in the one case there may have been extravagance.

"Is he authorised to do that; is it a part of the discharge of his duties, or is it rather an occasional and exceptional act on his part? I think it is a frequent act on his part; but I am not aware that there is any regulation binding him to do it."

The present Comptroller and Auditor General in a personal interview with the commission gave much the same statement of his conception of the duties of his office in respect to the prevention of wasteful expenditure. It is to be noted that whatever obligation he has in this respect is not in consequence His Implied Power as Officer of Parliament of any specific duty imposed upon him by law or regulation, but rather grows out of his status as the officer to whom Par- 
liament looks to keep it informed regarding the manner in which the funds voted by it are in fact expended.

To the commission it would seem that this is a duty which should be discharged to a far greater extent than it apparently is under the English system, and that there is no reason why the Auditor as Comptroller under the American system should not do the same. These officers have passed under their scrutiny the vouchers representing expenditures for all the services of the Government. They are in a peculiarly favorable position to detect whether one department is paying higher prices for the same articles or services than others, or is making an apparently lavish or unwise expenditure in any way.

Auditor's Ultimate Remedy Lies in Report to Parliament
There would seem to be no reason why it should not be their specific duty to call all such cases to the attention of the head of the department in which such expenditure takes place, and if no heed is given to such notice, to mention the facts in their annual reports. In most cases the heads of the departments are only too glad to secure information regarding the manner in which affairs are being conducted, and the proper action to secure economy will be taken without any publicity. Only in extreme cases will it be necessary to mention the matter in official reports. It would probably be a mistake to extend the duties of auditors, with respect to this matter, beyond this point of calling all cases of apparent waseful expenditure of money first to the attention of the interested service, and then, if need be, to the authority to whom report is made. To do more would be to substitute, in part at least, the responsibility of the auditor for that of the administration. This would mean a division of authority and a weakening of responsibility on the part of officials directly responsible for the conduct of affairs, that would be in the highest degree unfortunate.

Standing Committee on Public Accounts of the House of Commons. The commission has taken pains to point out how essential to the establishment of real control on the part of 226 
the fund granting authority is the putting into operation of a system by which that authority secures a complete and thorough report on the manner in which the funds granted by it have been expended by an officer independent of the spending departments and responsible to it alone. Such a system England finally secured through the creation of the office of Comptroller and Auditor General and the gèneral provisions regarding public accounting and reporting that are contained in the Exchequer and Audit Departments Act of I866.

Important as was this action, one further step had to be taken before England could fully meet the requirements of a system that would enable the House, in fact as well as in theory, to exercise a real control over expenditures. This consisted in the provision of means by which the House should avail itself of the information furnished to it by the audited statements of expenditures which it required of its officer, the Comptroller and Auditor General. Without the existence of means of this character through which the House would consider, and if need be, act upon the information given it, the submission of the audited statements of expenditure would be but an empty form. As Lord Welby pointed out in commenting upon the praiseworthy act of the Admiralty in inaugurating the system of audited statements of expenditures, this act accomplished little immediate good, since, "there being no

An Essential to Enforcing Responsibility provision in the act which forced the House of Commons to pass judgment on the account, it practically passed year by year without the notice it deserved."

The importance of ensuring that the accounts of expenditure would receive due consideration at the hands of the House of Commons did not escape the attention of the great Committee on Public Monies of $1856-7$. After recommending that there be a complete audit of all public accounts by an officer of, and directly responsible to, the House of Commons, it further recommended "that these audited accounts be annually submitted to the revision of a Committee of the House 


\section{BRITISH FINANCIAL ADMINISTRATION}

of Commons to be nominated by the Speaker." This suggestion was one of the first recommendations of the committee to be acted upon. In I86I Mr. Gladstone, as Chancellor of the Exchequer, secured the adoption of a standing order making provision for a standing committee of this character under the title of Committee on Public Accounts.

In this committee, which has had an uninterrupted existence since that date, England possesses one of the most interesting features of her whole system of financial administration. It is the crowning point of the system which she has step by step built up through which a real control over public expenditures is secured. Its organization, character and duties have been excellently described by Mr. Thomas Gibson Bowles, who was for years a member of the committee, in his testimony before the Select Committee on National Expenditure (1902), from which we take the following: ${ }^{1}$

An Instrument in the Hands of the Opposition

"The Committee of Public Accounts is a Standing Committee of I I members ( $I$ think it has been increased now to I5), whereof 5 constitute a quorum. It was established in I862 ; that was the date of the first Standing Order. The committee is nominated at the commencement of every Session by the House of Commons under Standing Order 57 for the 'examination of accounts showing the appropriation of the sums granted by Parliament to meet the public expenditure'; a phrase which, as will, I think, be seen, by no means completely describes the duties it performs, those duties being considerably wider than that phrase would suggest. The Chairman of the Committee is by usage always appointed from amongst the members of the Committee belonging to the Opposition. Though not restricted to the ground covered by the Comptroller and Auditor General in his annual Reports on the Appropriation Accounts, the Com-

${ }^{1}$ Report of Select Committee on National Expenditure, 1902, pp. 65-66. 


\section{THE AUDIT OF PUBLIC ACCOUNTS}

mittee in its usual practice is guided by those Reports in its selection of subjects for consideration, and of the officials, whether Accounting Officers or others whom it directs to attend for examination. The Comptroller and Auditor General calls its attention to the points whereon question has arisen during the audit of those accounts conducted by himself and his staff, and the Committee elucidates each point and reports on the whole to the House. Thus the Comptroller and Auditor General is, to a large extent, the acting hand of the Committee. He detects the points of question, presents them with such information concerning them as he has obtained, and leaves the Committee to pursue them further, to consider them, and report on them. It is therefore essential that the preliminary work of the Comptroller and Auditor General should be well and thoroughly done, or the Committee may fail in its subsequent work, and in its final object of securing and enforcing Parliamentary control over the public accounts.

"The Comptroller and Auditor General, I may say, always attends the Committee sittings, as does also a principal permanent officer of the Treasury. Now the functions of the Public Accounts Committee extend beyond the formality of the expenditure, to its wisdom, faithfulness and economy. Those functions, it must be remembered, embrace as well the receipt side as the issue side of the account. They amount to an enlarged revision of the Comptroller and Auditor General's Report on his Appropriation audit. They supplement the inquiries made by him and his officers in the course of that audit, by further inquiries made by oral examination, not alone of the Accounting Officer strictly so called, but of any other officials concerned in the expenditures whom the Committee may call before them.

"Moreover, and this is most important, the functions of the Conmittee extend to a supervision over the form

The Auditor General the Staff Agent of the Committee 
and number of the Estimates for the Grants in Supply, any change in which should be submitted to be approved by the Committee before being made, as was done in I867 and I88I.

"The Committee has always shown itself, I may say, strongly opposed to any diminution in the number of Votes of which the Estimates are composed as being calculated to diminish the control over those Votes of the House of Commons; it has set its face generally against making large Votes of lump sums, and has favored the subdivision of Votes rather than their inclusion in one. I have illustrative references here to a number of documents. with which I need not at present trouble the Committee.

"I may add that the functions of the Committee extend to an examination of the executive action of the Treasury as regards its compliance with the law (see Second Report, 1900). With so wide an horizon, so considerable a freedom in action, and so great opportunities in its. methods of inquiry as the Public Accounts Committee possesses, its capacities for public uses are great. It does. actually on the Appropriation Accounts what the Houseof Commons does theoretically on the Estimates, and does it to far more purpose; for it deals not with possibly. inaccurate Estimates of expenditure, but with the actual ascertained expenditure itself; and has before it for examination, not alone a Minister often imperfectly informed, but the very officers concerned with all the details. of the expenditure, whom, in case of question, it puts. upon their defence and elicits their first-hand explanations. As a check upon, not merely extravagant or unauthorised expenditure, but also upon unwise methods of management, this Committee is probably more effectual: than the House of Commons itself."

We have reproduced this statement of the work and provinceof the Committee on Public Accounts, notwithstanding the: 


\section{THE AUDIT OF PUBLIC ACCOUNTS}

length, since it presents in a peculiarly authoritative and clear form not only the technical duties and powers of the committee, but the spirit in which these duties and powers are exercised. ${ }^{1} \mathrm{Mr}$. Bowles has not overdrawn the importance of this body in the general system for the control of public expenditures. All officials interviewed by the commission united in affirming the important place that it occupied and the great value of the work done by it. Its duties are taken very seriously by the members of the committee and are performed with the utmost conscientiousness. Particular notice should be taken of the wide scope of its powers. It is not limited to the investigation of points raised by the appropriation accounts as reported by the Comptroller and Auditor General: on the contrary, it has the power to scrutinize and report upon almost any matter having to do with the management of the public finances. It considers the form in which the estimates should be submitted; it passes upon the question of the number of votes under which appropriations should be made and the subheads under which an accounting should be had; it examines into the conduct of the Treasury; it satisfies itself as to whether due economy and efficiency have been displayed by the several services in the expenditure of funds; finally, it pays special attention to the technical accounting procedure employed by the Government.

To such an extent does it consider this latter matter that its reports, together with the Treasury minutes setting forth the action of that authority on the recommendations of the committee, constitute in effect the general regulations governing the accounting methods of the Government. This is evidenced by the fact that in I9I I the Comptroller and Auditor General caused to be prepared and published an epitome of all the reports of this committee since its establishment, with the Treasury minutes relating thereto, which was fully indexed in order that all accounting officers might readily consult the

${ }^{1}$ See also, Young: The System of National Finance, London, 1915. 
orders that have been issued and were in force governing accounting methods. ${ }^{1}$

Another point of no little importance is the fact that this committee both in its personnel and its work is essentially non-partisan in character. With the chairman chosen from "the opposition," there is no danger of the committee passing over delinquencies of the Executive as a matter of party expediency. On only two occasions has the custom of choosing the chairman from "the opposition" been departed from. All officials interviewed emphasized in the strongest way possible this high character of the committee and the spirit in which it performs its duties.

Finally, attention should be directed to the skill displayed in adjusting the powers of this committee to those of the Treasury. We have already seen how careful Parliament was,

To Insure Impartiality Committee Reports Findings to Treasury
This

Practice

Fastens Responsibility on Executive in defining the duties and powers of the Comptroller and Auditor General, to avoid distributing responsibility for the management of the financial affairs of the nation between that officer and the Treasury, and to preserve the latter body as the one authority possessing final responsibility and power. The same care has, consciously or unconsciously, been displayed in defining the function of the Committee on Public Accounts. This committee, with all its great powers of investigation and report, is in no sense the supreme authority with respect to methods of financial management. Its conclusions, as embodied in its reports, in themselves have no force. All of its recommendations are reported to the Treasury: they are, in effect, recommendations that the Treasury do this or that, or that it require that this or that be done by the services it controls. It remains for the Treasury to decide whether it will or will not act upon such recommendations. Its decisions are embodied in what are known as "treasury min-

${ }^{1}$ Epitome of the Reports from the Committees of Public Accounts I857 to $x 910$ and of the Treasury Minutes thereon, with an Index. The compilation goes back to 1857 , since there was a Committee on Accounts prior to the establishment of the Permanent Standing Committee in 1862 . 
utes," which recite the recommendations of the committee and set forth the action that the Treasury has decided to take upon them. It is by no means unusual for the Treasury to decline to put the recommendations of the committee into force, or at least to adopt them in a partial or modified form. The Treasury, of course, must feel that it is on very solid ground when it declines to act upon the recommendation of the committee, and it takes pains to point out in its minute the reasons for such refusal.

This absence of determinative power, together with the fact that the House as a whole devotes but little time to a consideration of the reports of the committee, has given rise to a feeling on the part of many that certain changes might, with advantage, be introduced into the system as it now exists. We thus find that Mr. Bowles, though strongly emphasizing the power and influence of the committee, yet believes that, in two respects at least, its system could be improved. In his testimony, to which allusion has been made, he thus said: ${ }^{1}$

"The Public Accounts Committee, however, is under some serious disadvantages. It has no power, even after the most minute examination and on the clearest evidence, to disallow any item. It can only 'call attention' to that item. Moreover (and this I think is serious), there is no provision, either in the Standing Orders or in the unwritten law of the House of Commons, providing for the certain consideration of the Reports of the Public Accounts Committee in which it has called attention to matters of question. Matters of very high financial importance or irregularities and abuses of a most mischievous character thus escape all public attention or Parliamentary discussion. I should suggest (and this I suggest most definitely) that, in order that the work of the Committee may have its due effect, some certain occasion should be provided for the consideration by the House of

${ }^{2}$ Report of Select Committee on National Expenditure, 1902, p. 67. 


\section{BRITISH FINANCIAL ADMINISTRATION}

Commons of its Reports when presented, and for taking a decision of the House upon the recommendations embraced therein."

Logical as this action would seem to be, it yet should be recognized that any step having for its effect the vesting of

Would $\mathrm{Be}$ in Violation of Principle of Control discretion in the committee or even in the House as a whole, except possibly when the issue of rules of the most general character are concerned, would represent a serious inroad upon the fundamental principle now enforced that responsibility for action rests in the Treasury. The commission doubts whether Parliament could consistently, or would seriously, consider any action that would do violence to this basic principle which constitutes, as it were, the very cornerstone of the whole system for the administration of the English national finances. 


\section{CHAPTER XII}

\section{THE SYSTEM OF FINANCIAL REPORTS}

Finance Accounts; Appropriation Accounts; The Estimates; Lack of Any General Report of Audited Receipts and Expenditures.

The theory of legislative determination and control of public revenues and expenditures, if it is to be effectively carried out, demands that the legislature, and through it the people, shall be put in possession of full and detailed information regarding the financial condition and operations of the Government. Only as it is given this information, and given it in such a form that its significance can be readily seen, can it properly perform its function of determining the financial and work program of the Government. In our consideration of the control of exchequer issues, the preparation and submission of estimates, and the audit of accounts, we have incidentally made reference to certain reports and information that are laid before Parliament. It is now our purpose to describe more in detail the character of these and other documents with a view to presenting in one place a statement of the character of the information that is furnished Parliament, and upon which the latter bases its action.

In considering this phase of the English financial system, the first point to be noted is that Parliament is furnished with two sets of figures purporting to show national income and

Two Sets of Reports to Parliament outgo: (I) Those showing exchequer receipts and issues; and (2) those showing audited receipts and expenditure. We will consider in turn the reports giving each of these two classes of data.

Finance Accounts. The oldest and most used report giving information regarding national finances is the annual report 


\section{BRITISH FINANCIAL ADMINISTRATION}

entitled "Finance Accounts of the United Kingdom of Great Britain and Ireland for the Financial Year —_ ended March 3Ist —-, "but which in ordinary use is referred to by the short title of "Finance Accounts." The publication of this report dates from 1802 . Nothing illustrates more clearly the old idea that the function of Parliament in respect to the expenditures of the Government ceased when it had granted a certain sum of money to the Crown for the conduct of Government than the fact that it was not until this date, that is, the beginning of the nineteenth century, that the Crown was even so much as required to submit an account or report of the moneys received and expended by it. As Lord Welby points out in the Memorandum from which we have so frequently quoted : ${ }^{1}$

"Until I802, therefore, Parliament had no information of any kind as to the expenditure of the money which it had voted, unless a return for a special object was asked and granted. It is true that under the financial pressure of the wars of William and Anne, Commissioners were from time to time appointed to examine the accounts, but

Description by Lord Welby these Commissons were too often of a party character; their reports were not, therefore, trustworthy, and were used for party purposes. During the long peace no demand arose for such inquiries, and though more thorough examination into accounts was instituted by Commissions appointed after the American and during the French War, and though these Commissions brought to light irregularities and pointed out defects in financial organisation, they had no continuity, and had none of the elements of an audit. . . . It will be seen, then, that from the Revolution ( 1688 ) until I802 the House of Commons received no information as to the public expenditure except that which the Chancellor of the Exchequer might think fit to give them in his Budget speech, and that was

${ }^{1}$ Report of Select Committee on National Expenditure, I902, p. 228. 
usually of very meagre character. It may be added that from I802 until I866 (the date of the Exchequer and Audit Act) the House learned only the issues from the Exchequer. Thus it knew the sums which had been imprested (advanced) to the Departments from the Exchequer; it did not know how the Departments had actually expended those imprests."

This report, "Finance Accounts," has not changed its essential character since its first issue. It is a summary statement of Government income and expenditure from the standpoint of Exchequer receipts and issues, and of the resources and liabilities of the Government at the end of the year to which it relates. It consists of two basic tables, in the form of balanced statements, giving a grand recapitulation of the facts regarding these two points, and a series of supporting tables giving the details entering into the totals shown in these tables. All this information is presented in an exceptionally clear and compact form. The whole report for the year ended March $3 \mathrm{I}$, I9I4, made but a small octavo pamphlet of IOI pages.

One of the great merits of this report is the promptness with which it is rendered. Thus the report for I9I4 was submitted and ordered printed May 25 following, or less than two months after the close of the year to which it related. In point of fact the first and most important of the two basic tables is laid before Parliament in the form of a special return at a still earlier date, that for I9I 4 being submitted on April 27, less than a month after the closing of the books for the year.

This return, constituting as it does the general summing up of the financial operations of the Treasury during the year, is much the most important financial return that is laid before Parliament. It is upon the figures contained in it and in the Estimates that the Chancellor of the Exchequer bases his budget proposals. As it consists of but a single table in two parts and occupies but two quarto pages, the return for I9I 4 is here reproduced in full : 
YEAR ENDED 3IST

Part I.-An Account of the Public Income and Expenditure of the 3ist March, igi4, Prepared in Compliance with Section

Income

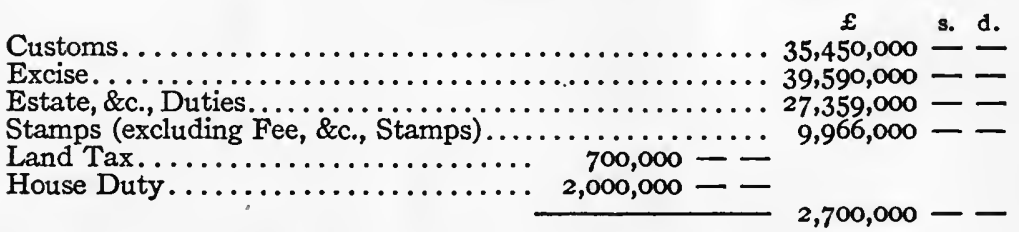

Property and Income Tax (including Super Tax)...... 41,249,000 - Land Value Duties........................... ${ }_{715,000}=-$ Post Office..................................

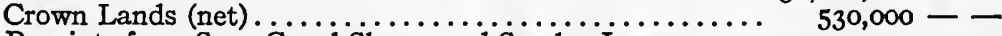
Receipts from Suez Canal Shares and Sundry Loans...... Miscellaneous................................ $2,303,924$ I4 5

TotaL Income................... $\overline{£ 198,242,897 \quad 4-}$ 
MARCH, I9I4

United Kingdom of Great Britain and Ireland in the Year Ended the 4 OF The Sinking Fund Act, I875 (38 \& 39 Vict., c. 45).

Expenditure

I. Consolidated Fund Services

National Debt Services:

Permanent or Fixed Annual Charge:

Funded Debt:

Interest.

$£ \quad$ s. d.

$£$

s. d.

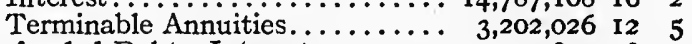

Unfunded Debt-Interest......... I, I I 5,849 I8 7

Management of Debt.......... 166,529 I9 9

New Sinking Fund $\ldots \ldots \ldots \ldots \ldots, 5,228,484$ I3 I

Road Improvement Fund . . . . . . . . . . . . . . 1,394,951 - -

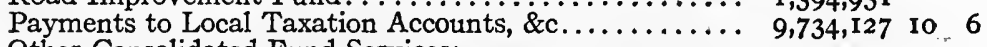

Other Consolidated Fund Services:

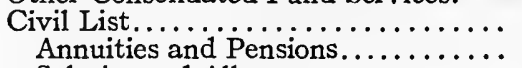

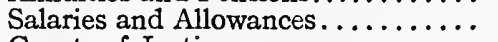

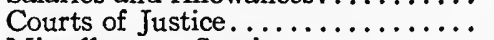

Miscellaneous Services... $533,042 \quad 7 \quad 3$

Miscellaneous Services......... $317,725 \quad 4 \quad$

$470,000--\frac{1}{6}$

316,575 I3 6

$56,547 \quad 2 \quad 1$

$\mathrm{I}, 693,890 \quad 6$ 10

II. SUPPly SERvices

Army and Ordnance Factories....... 28,346,000 - -

Navy .................. 48,833,000 - -

Civil Services................. 53,901,000 - -

Customs and Excise and Inland Revenue

Departments.............. 4,483,000 - -

Post Office Services................

160,170,000- -

Total Expenditure.................. 197,492,968 I7 4

Surplus of Income over Expenditure in the Year Ended 3Ist

March, I9I4......................... 
Part II.-An Account of the Balances of Public Money Remaining MENTS (NOT BEING INCOME AND EXPENDITURE AS SHOWN IN

THE BALANCES IN THE

\begin{tabular}{lllllll}
\hline \hline Receipts & s & s. d, & $£$ & s. d. \\
\hline
\end{tabular}

Balances in the Exchequer on the Ist

April, I9I3:

At the Bank of England........ 5,389,135 84

At the Bank of Ireland........... $940,024 \quad \mathbf{I}_{3} \quad 2$

Repayment of Advances:

For purchase of Bullion for Coinage...

Interest on Exchequer Bonds issued under the Capital Expenditure (Money) Act, 1904, repaid from Army and Navy Votes..................

Raised by creation of Debt:

By Treasury Bills for Supply...... 27,500,000 - -

Under the Telegraph (Money) Act, I913:

By Terminable Annuities chargeable on Post Office Vote....... .

Under the Telephone Transfer Act, I9 I :

By Terminable Annuities chargeable on Post Office Vote........

Under the Post Office (London) Railway Act, I913:

By Terminable Annuities chargeable on Post Office Vote.......

Under the Land Registry (New Build$90,000-$ ings) Act, I900:

By Terminable Annuities chargeable on the Vote for Public

Buildings, Great Britain.......

Temporary Advances on the credit of Ways and'Means:

By Treasury Bills. . . . . . . . 6,500,000 - -

By Other Advances............

Cunard Loan:

$10,000,000--$

Repayment on account of Principal...........

Suez Canal Drawn Shares . . . . . . . . . . . . . .

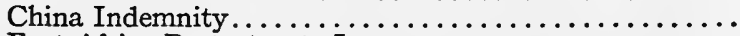

East Africa Protectorate Loan:

Repayment on account of Principal and Interest...

Surplus of Income over Expenditure in the Year ended 3 Ist March, I9I $4 \ldots \ldots \ldots \ldots \ldots \ldots \ldots \ldots \ldots \ldots$

$$
£_{50,694,314-6}
$$

* The balance at the Bank of England includes a sum of $\$ 454,000$ representing the unSection 9 of the Finance Act, 1908, and $£ 1,579.000$ representing the unissued part of the Old Finance Act, 1911.

NotE.-Exchequer Bonds for $£ 380,000$ were issued in the year to the National Telephone

Transfer Act. 1911. The transaction does not appear in the above statement, as it did not Treasury, I3th April r914.

I hereby certify, pursuant to the provisions of the Act $38 \& 39$ Vict. c. 45, s. 4 ,

Exchequer and Audit Department, 20th April, 1914. 
IN THE EXchequer oN THE IST, APRIL, I9I3: of THE RECEIPTS AND PAYPART I.) IN THE YeAR ENDED 3IST MARCH, I9I4; AND OF

EXCHEQUER ON THAT DAY.

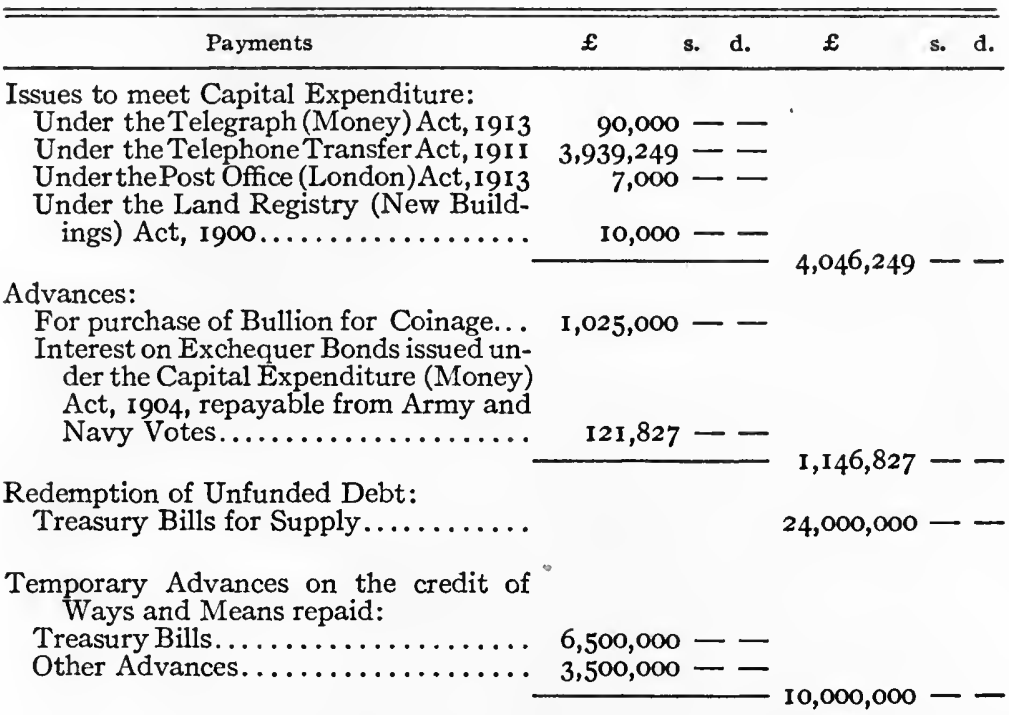

Old Sinking Fund, I907-8, issued under

Section 9 of the Finance Act, 1908 .

$86,000--$

Old Sinking Fund, I9I0-II :

Issued under the Finance Act, I9I I :

Section 16 (I) (b).

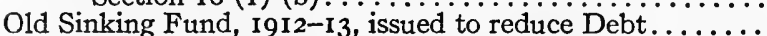

Cunard Loan Repayments:

Issued to the National Debt Commissioners under the

Cunard Agreement (Money) Act, r904.............

Suez Canal Drawn Shares:

Issued to reduce Debt under the Finance Act, 1898 . . . . .

China Indemnity:

Issued to reduce Debt under the Finance Act, 1906. .....

East Africa Protectorate Loan Repayments:

Issued to reduce Debt under the Finance Act, I9I I . . . . .

Balances in the Exchequer on the 3Ist

$88,500-\frac{}{26}$

March, I914:

At the Bank of England*........ 9,349,052 2 I I

At the Bank of Ireland........... I,085,467 9 I

$130,000--$

8,427 I $8 \quad 9$

$571,606 \quad$ I3 7

2, II $5-$

$10,434,519$ I2

$£_{50,694,314-6}$

issued part of the Old Sinking Fund, 1907-8, which was made applicable to Expenditure under Sinking Fund, 1910-11, which was made applicable to Expenditure, under Section 16 of the

Company in part payment of the purchase money of their undertaking under the Telephone involve any Exchequer receipt or issue of cash.

that the foregoing Accounts are correct.

JOHN BRADBURY.

H. J. GIBSON,

Comptroller General of the Receipt and Issue of $\mathrm{His}$

Majesty's Exchequer and Auditor General of Public

Accounts. 


\section{BRITISH FINANCIAL ADMINISTRATION}

Much the most interesting feature of this showing is the distinction that is made between "public income and expenditure" proper, on the one hand, and "receipts and payments, not being income and expenditure," on the other, and the further distinction in respect to the first set of figures between expenditures constituting a permanent charge upon the Consolidated Fund and those that are met by annual appropriations for the supply services. This table, as has been stated, is in effect an advance statement of one of the two basic tables contained in the Finance Accounts, and consequently is supported by the detail tables contained in that report which appears about a month later.

The second basic table of the "Finance Accounts" report, that showing the resources and liabilities of the Government at the end of the year, is apparently not laid before Parliament as a special return. For it reference must accordingly be made to the "Finance Accounts" report itself. This table is reproduced in full on page 244 .

It will be noted that in this table no effort is made to include other than purely commercial assets. In other words, only those items are listed which represent assets which, theoretically at least, the Government can convert into cash. No attempt is made to include the value of the physical properties of the Government, such as Crown lands, public buildings, navy and other vessels, materials and supplies on hand, etc. The report includes other tables giving: "Contingent and nominal liabilities," which a note states are ones which the state is not likely to be called upon to meet; "loans guaranteed by the British Government," and "unrepaid advances made to Colonial Governments, etc., from votes of Parliament, etc."

Incidentally the table reproduced brings out certain information regarding the method pursued by England in financing Government works requiring a large capital expenditure. This is a feature of the English financial system that it would be of great interest to examine in greater detail. To do so would, 


\section{THE SYSTEM OF FINANCIAL REPORTS}

however, involve an examination of so many special statutes and so large an amount of descriptive matter that it is not feasible to pursue the subject further in the present report.

Mention has been made of the fact that the "Finance Accounts," in addition to presenting the general summary of assets and liabilities which we have reproduced, also gives a series of tables showing operations during the year in relation to the public debt. For purposes of completeness, mention should here be made of a special return which is annually submitted to Parliament, in which are given the figures regarding public debt operations during a series of years. The figures are taken largely, if not wholly, from the "Finance Accounts" reports. This return, the title of which for the I9I4 return is "National Debt: Return Showing for Each Financial Year commencing the Ist April from I875 to I9I4, inclusive," shows :

I. The total amount of dead weight debt outstanding on the Ist April; the amounts which were made available in each year to I9I3-I4; inclusive, for reduction of Debt; distinguishing the sum expressly provided for service of the Debt, the old Sinking Fund, and Miscellaneous Receipts; the Gross Amount of Debt redeemed; the amount of Debt Created; and the Net Increase or Decrease of Debt in the Year.

II. A similar Statement in respect of other Capital Liabilities.

III. A similar Statement in respect of the aggregate Gross Liabilities of the State gives very full information regarding all transactions and changes which have taken place during the years covered with respect to the funded and other liabilities of the Government.

These two special returns, that giving Exchequer receipts and issues and that giving information regarding national debt 


\section{National Debt}

Statement Showing the Aggregate Gross Capital Liabilities of the State, the Estimated Assets, and also the Exchequer Balances on 3ist March I9I3, and 3Ist March I9I4.

\begin{tabular}{|c|c|c|c|}
\hline & $\begin{array}{l}\text { On March } \\
3 \mathrm{I}, \mathrm{I} 9 \mathrm{I3}\end{array}$ & $\begin{array}{l}\text { On March } \\
3 I_{1}, I_{9 I 4}\end{array}$ & $\begin{array}{l}\text { Increases }(+) \\
\text { or Decreases }(-) \\
\text { in the year ended } \\
\text { March 3I, I9I4 }\end{array}$ \\
\hline 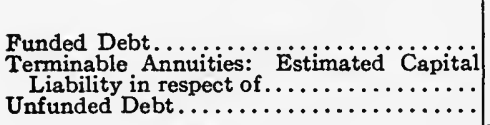 & $\begin{aligned} \stackrel{£}{£} \\
593,453,857 \\
31,519,908 \\
3 I, 500,000\end{aligned}$ & $\begin{aligned} \stackrel{E}{E} \\
586,717,872 \\
29,552,219 \\
33,500,000\end{aligned}$ & $\begin{array}{c}\stackrel{f}{1} \\
-6,735,985 \\
-1,967,689 \\
+2,000,000\end{array}$ \\
\hline Total... & $656,473,765$ & $649,770,091$ & $-6,703,674$ \\
\hline 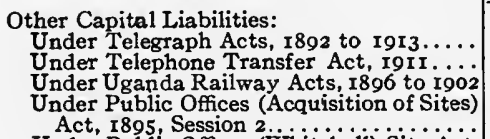 & $\begin{array}{r}8,423,549 \\
9,328,563 \\
3,417,099 \\
380,091\end{array}$ & $\begin{array}{r}\text { II }, 452,240 \\
9,478,052 \\
3,196,832 \\
373,777\end{array}$ & $\begin{array}{r}+3,028,691 \\
+\quad 149,489 \\
-\quad 220,267 \\
-\quad 6,314\end{array}$ \\
\hline $\begin{array}{l}\text { Under Public Offices (Whitehall) Site Act, } \\
\text { I897.... } \\
\text { Under Royal Niger Company Act. } \\
\text { Under Naval Works Acts, I895 to } 199 . . \\
\text { Under Military Works Acts, I897 to I903. } \\
\text { Under Land Registry (New Buildings) Act, }\end{array}$ & $\begin{array}{r}423,592 \\
558,647 \\
17,045,010 \\
9,700,177\end{array}$ & $\begin{array}{r}415,904 \\
530,932 \\
16,354,807 \\
9,231,962\end{array}$ & 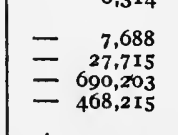 \\
\hline $\begin{array}{l}\text { I9oo. } \\
\text { Under Pacific Cable Act, Igor } \\
\text { Under Public Offices Site (Dublin) Act, }\end{array}$ & $\begin{array}{r}200,415 \\
1,792,433\end{array}$ & $\begin{array}{r}205,709 \\
1,768,661\end{array}$ & $\begin{array}{r}\mathbf{5 . 2 9 4} \\
\mathbf{2 3 . 7 7 2}\end{array}$ \\
\hline $\begin{array}{l}\text { Inder Public Buildings Expenses Act, I9o } \\
\text { Und } \\
\text { Under the Cunard Agreement (Money) }\end{array}$ & $\begin{array}{r}201,828 \\
1,393,252\end{array}$ & $\begin{array}{r}195,284 \\
1,352,859\end{array}$ & $\begin{array}{r}-6,544 \\
-\quad 40,393\end{array}$ \\
\hline $\begin{array}{r}\text { Act, reo4 } \\
\text { Under Post Office (London) Railway Act, } \\
\text { rgr } 3 \ldots \ldots \ldots \ldots \ldots \ldots \ldots \ldots \ldots \ldots \ldots \ldots \ldots\end{array}$ & $\begin{array}{r}1,950,000 \\
\ldots \ldots \ldots \\
\end{array}$ & $\begin{array}{r}1,820,000 \\
7,000 \\
\end{array}$ & $\begin{array}{r}-130,000 \\
+\quad 7,000 \\
\end{array}$ \\
\hline Total & $54,814,656$ & $56,384,019$ & $+1,569,363$ \\
\hline Total Gross Liabilities. . & $f_{7 I I, 288,42 I}$ & $706,154,110$ & $+5, \mathrm{r}_{34,3 \mathrm{II}}$ \\
\hline $\begin{array}{l}\text { Estimated Assets: } \\
\text { Estimated Market Value of Suez Canal }\end{array}$ & 30.015000 & 34020000 & -4086000 \\
\hline 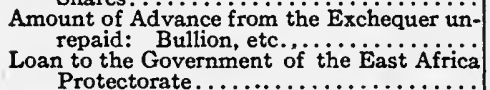 & $\begin{array}{r}400,000 \\
46,530\end{array}$ & $\begin{array}{r}34,929,000 \\
190,000 \\
46,044\end{array}$ & $\begin{array}{r}-4,000,000 \\
-\quad 210,000 \\
-\quad 486\end{array}$ \\
\hline $\begin{array}{l}\text { Contribution of Colonies to Capitai Expendi- } \\
\text { ture on the Pacific Cable. ... W O The } \\
\text { Nominal Value of Debenture Stock of the } \\
\text { Cunard Steamship Company held as } \\
\text { security for repayment of Advances un- } \\
\text { der the Cunard Agreement (Money) }\end{array}$ & $\begin{array}{r}40,530 \\
1,311,203\end{array}$ & $\begin{array}{r}40,044 \\
1,294.534\end{array}$ & $\begin{array}{r}400 \\
-\quad 16,669\end{array}$ \\
\hline 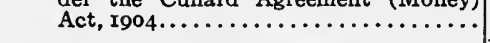 & I,950,000 & $1,820,000$ & $-130,000$ \\
\hline Total Estimated Assets...... & $f_{42,722,733}$ & $38,279,578$ & $-4,443,155$ \\
\hline $\begin{array}{l}\text { Exchequer Balances at the Banks of England } \\
\text { and Ireland............................ }\end{array}$ & $£ \quad 6,329,160$ & $10,434,519$ & $+4,105.359$ \\
\hline
\end{tabular}


operations, have been considered in connection with the general report entitled "Finance Accounts," since they are in effect little more than advance sheets of that report, though the data are presented in a form somewhat different from that which they have in the report itself. In this connection mention should also be made of the fact that current information regarding Exchequer receipts and issues is published weekly in the official organ, the London Gazette, from which it is reproduced in other papers. The statement published in this way is of a more summary character than the corresponding table in the "Finance Accounts" and the special return. The figures are given in a form to show total receipts and issues by main categories from the beginning of the fiscal year to the date of the statement, in comparison with the figures for the corresponding period of the previous year.

If, therefore, we consider all these statements and reports together, the conclusion must be reached that they get before Parliament and the public the most essential facts regarding treasury conditions and operations in an exceeding clear and compact form and with great promptness. In making this statement, however, two facts of great importance should be borne in mind. The first is that the figures here given are of A Summary of All Essential Exchequer receipts and issues and not of audited income and expenditure; and, furthermore, that even from this standpoint they do not include all public receipts and payments, since those extra receipts which are granted to the services producing them, in the way of appropriations in aid, do not pass through the Exchequer, and thus do not appear upon either side of the Exchequer account. The second is that, for the reasons pointed out in the Treasury Minute of April I6, I885, which has been quoted, ${ }^{1}$ the figures do not fairly represent public expenditures according to votes or classes of votes except at the dates when the quarterly and annual adjustment of issues has been had.

It follows from the foregoing that the figures contained in ${ }^{1}$ See p. 152. 
the "Finance Accounts," and the returns and statements prepared on the same basis as that publication, cannot be taken as furnishing either a complete or an accurate statement of public income and expenditure. Even were they complete, they are not of a character to give information regarding the details of expenditure. The furthest point to which the itemization of expenditure is carried is that of the 153 votes and the items constituting a permanent charge upon the Consolidated Fund. This statement is not made in the way of criticism. Parliament and the public have need of two kinds of information regarding the national finances; that showing in a large way the resources and liabilities of the Government as a basis upon which to frame financial policies and a general work program, and that giving the details of revenue and expenditure in order that rigid control may be exercised over the manner in which the financial affairs of the Government are being administered. If we make exception of the various defects arising out of the system of appropriations in aid, it may be said that the statements that we have been considering meet the requirements for information of the first class. For the purposes which they are to serve it is not necessary that they. should be absolutely accurate, nor that they should itemize the figures to any great extent.

.In one respect, however, the "Finance Accounts" as a pub-

A Defect in the Form of Statement lic document is, in the opinion of the commission, open to serious criticism. Reference is made to the failure to include in the report tables giving the facts regarding treasury conditions and operations for a series of years, such, forexample, as is given in the special return for the national debt. It is only as figures for a given year are compared with the corresponding figures for a series of years preceding that their full significance can be seen. The latter figures can, of course, be secured by consulting the "Finance Accounts": for those years, but members of Parliament and the general public should not be put to the necessity of making such a search.

Appropriation Accounts. If we turn now from the ques246 
tion of Exchequer receipts and issues to that of actual receipts and expenditures, information must be sought in the reports of the Comptroller and Auditor General. Of these, far the, most important is the annual report made by him entitled "Appropriations Accounts," in which is given his audited statement of the manner in which the votes for the supply services have been expended, this expenditure being accounted for according to the subheads set forth in the estimates.

In form this report consists of a collection of statements of account by the accounting officers charged with the rendering of the accounts for the several votes, with the certificate of the Comptroller and Auditor General attached and accompanied by such explanations and comments as the latter deems it fit to make. Each vote is the subject of a separate account, and thus there are as many statements as there are votes. These several statements are bound in volumes, one for the civil serv-. ices and the revenue departments, one for the army, and one for the navy.

The only attempt to bring together the figures contained in the several accounts is represented by tables in which the facts are summarized by classes of votes and by individual votes. Following is a copy of the table contained in the "Appropriation Accounts" for I9I2-I9I3 for the civil services and revenue departments, in which the figures are given by classes of votes. Other tables give the same facts according to individual votes. Tables are quoted on pages $248 \mathrm{ff}$.

'The only further attempt to analyze the figures' showing expenditures so as to bring out significant features is represented by a very interesting table given at the back of the report, in which the effort is made to adjust payments made by one service on account of another. in such a way as to show the gross and net cost of each service. It will be remembered that the expenses of the several services are not entirely covSupplementary ered by their respective votes. The best example of this is furnished by the practice of having all expenditures for quarters, stationery, etc., borne by the votes for Public Works and

Analyses by Votes 


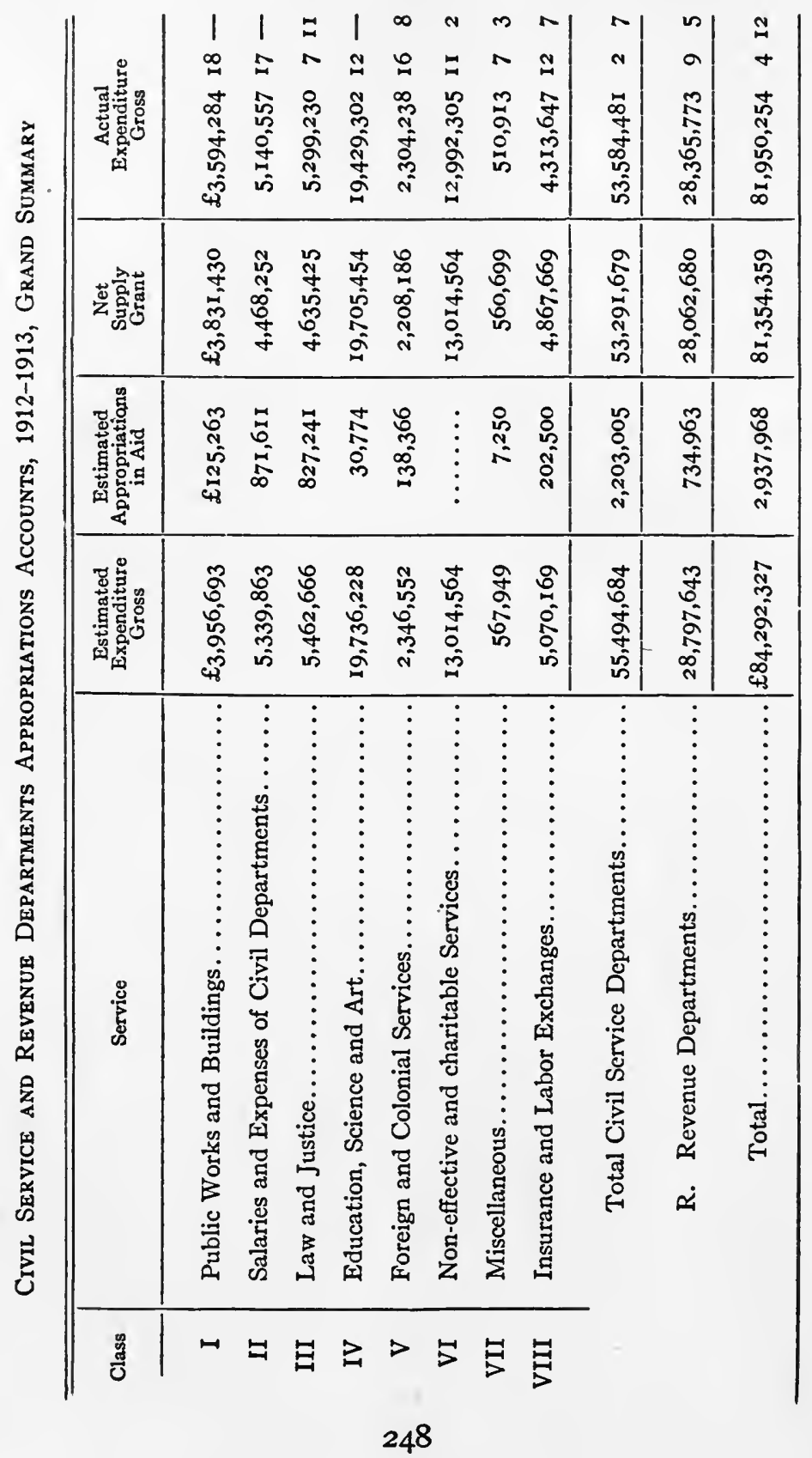




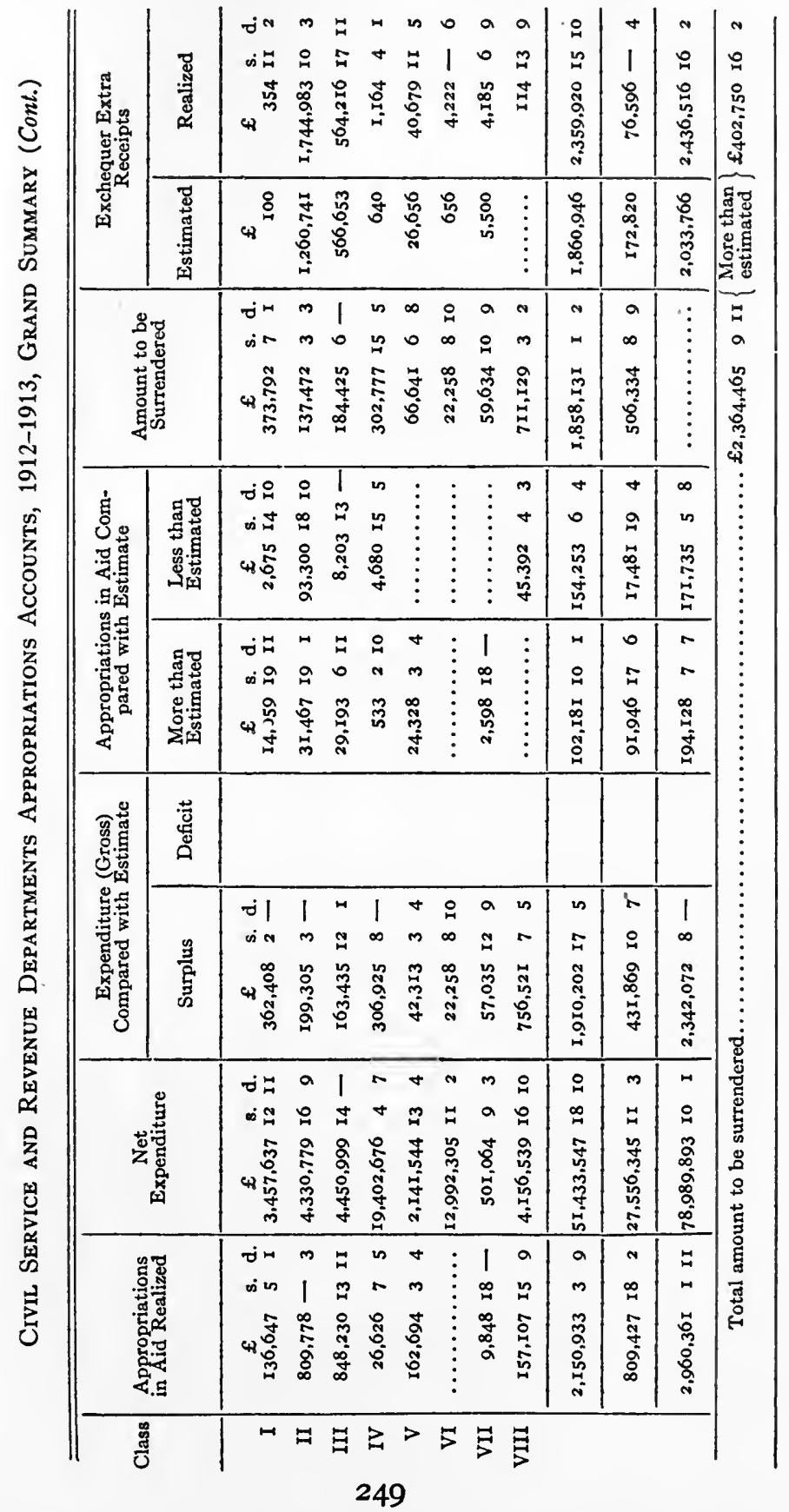


Gross and Net Total Cost of Civil Services and Revenue Departments imately, the Gross and Net Cost of Each Vote. It IS CoMpiled THE Respective Departments (Office of Works, Sta CURRED, OR SERVICES ' RENDERED, ON

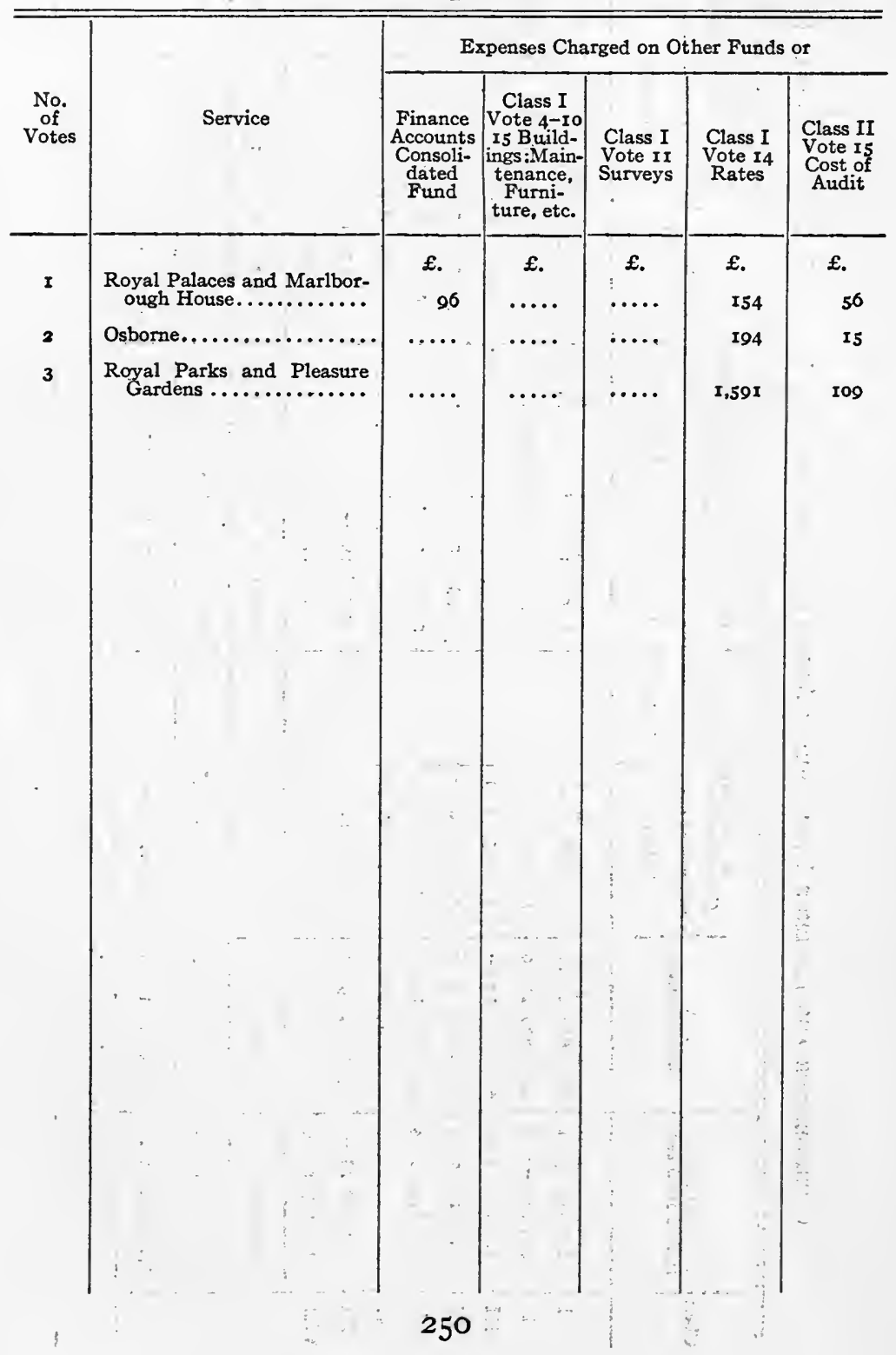




\section{THE SYSTEM OF·FINANCIAL REPORTS}

For the Year Ended 3ist March, 19r3. This Statement Shows, ApproxFROM THE FINANCE ACCOUNTS AND FROM RETURNS FURNISHED BY TIONERY OFFICE, ETC.) BY WHOM EXPENDITURE IS INBehalF OF OTHER Departments.

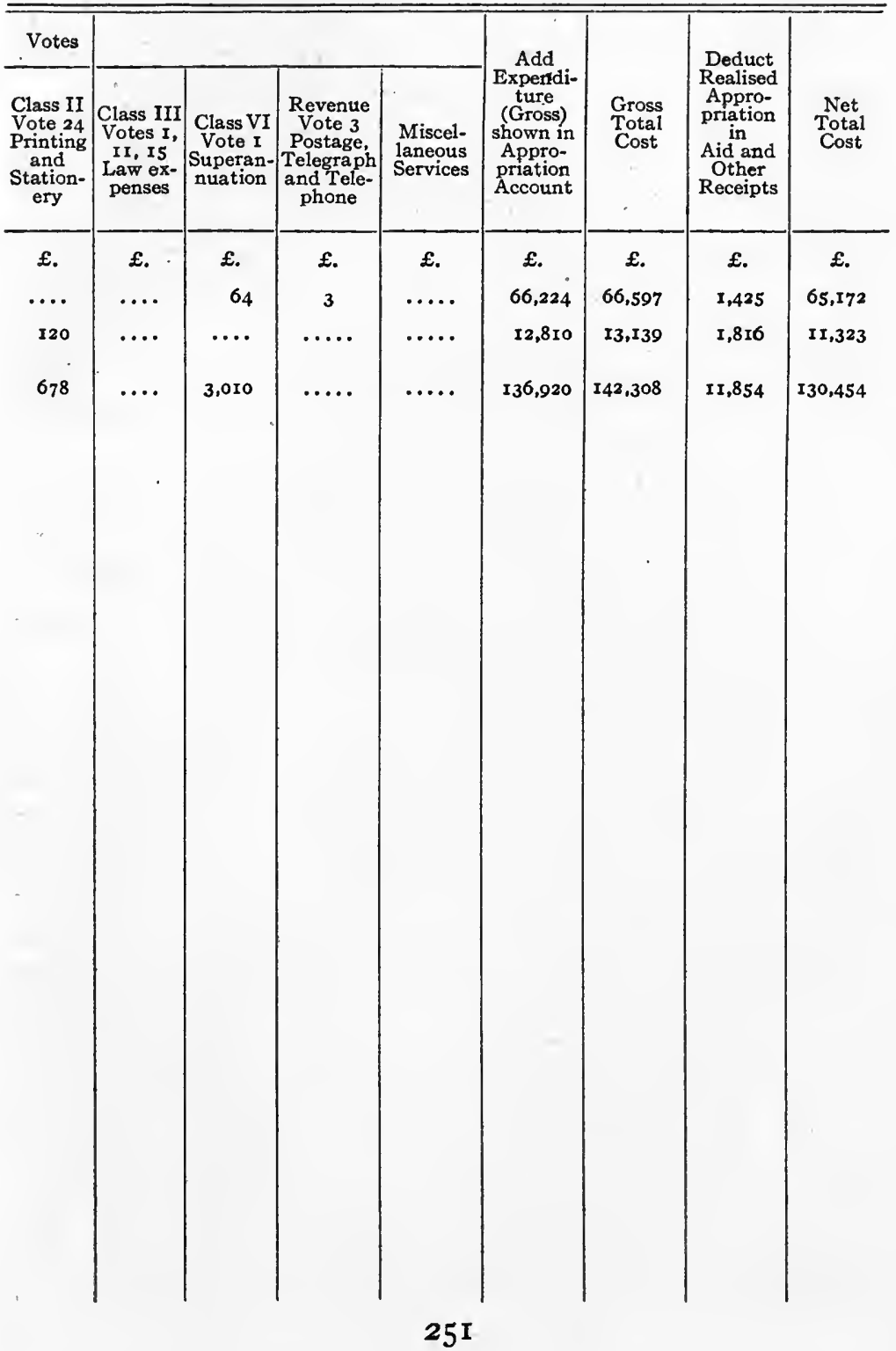


the Stationery Office. If the true cost of maintaining each service is to be known, it is thus necessary to add to the expenditures of each service as borne by the vote the expenditures met out of votes for these and other services and to deduct the expenditures made from its vote for services other than its own. This has been done in the table, to which attention has been directed. The preceding representation of the column headings and the figures for the first few votes will show the character of the table on pages $250-5 \mathrm{I}$.

In this table it will be seen that the facts are given only by votes. As many votes cover a whole group of services, that for the Home Office, for example, covering the Home Office

No

Comparison by Years proper, the inspection of factories, the inspection of mines, etc., inadequate information is given regarding the cost of particular services.

Finally, it should be noted that no recapitulation or analyses are given showing audited expenditure for a series of years, nor are the several summary tables in the separate volume containing the appropriation accounts brought together in a consolidated statement for all the supply services.

The Estimates. Although a full account has been given of the character of data contained in the books of estimates, mention of these documents should be made here since they constitute one of the means through which information regarding the finances of the Government is laid before Parliament. RefComparative erence to the chapter in which the form and character of the Summary

Estimates are considered will show that, in addition to giving the estimates proper in comparison with grants for the current year, each volume contains a table in which the estimates are compared with grants for the current year, expenditures as per appropriation accounts for the year next preceding, and audited expenditures for each of the eight years preceding that. This comparison is by votes and classes of votes. The same criticism that has been made of the showings in the "Appropriations Accounts," that the comparison goes no 
deeper than the individual votes and thus does not even reach the several distinct services of the Government, applies to this table, and also that no attempt is made to bring the figures contained in the several books of estimates into one consolidated statement covering all the supply services.

Lack of Any General Report of Audited Receipts and Expenditures. If we attempt now to consider at one time all the various documents in the nature of financial reports which are laid before Parliament, we cannot but be struck with the fact that there exists no document in which the data contained in the several reports that we have been considering have been brought together in a consolidated statement. Surprising as it may be, the fact is that the English Government makes no general report of the real expenditures of the Government. In the appropriation accounts and in the other reports of the Comptroller and Auditor General one can follow in great detail the expenditures for particular purposes, but nowhere can one find a complete statement of the audited expenditures of the Government as a whole. Furthermore, due primarily to the present system of appropriations in aid, it is doubtful whether such a statement can be prepared. The fact is that there seems to be little demand in England for detailed data that will go beyond the vote, and for expenditures by votes the figures showing exchequer issues are deemed to be sufficiently accurate for all practicable purposes. The question of having expenditures analyzed by functions, objects of expenditure, character of expenditure, etc., such as was urged in the report of President Taft's Commission on Economy and Efficiency on "The Need for a National Budget," never seems to have been raised.

To the commission the absence of a general consolidated statement of audited expenditures of the Government as a whole, in which the items are classified not only by votes but also by individual services, and in which are brought together 


\section{BRITISH FINANCIAL ADMINISTRATION}

expenditures for the same services or purposes, if met partly from the Consolidated Fund services and partly from the supply services-this absence constitutes a serious defect in the British financial system. It is one, moreover, which could easily be remedied did Parliament so desire. All that would be required would be: (I) The abolition of the system of appro-

Changes

Necessary to Consolidation priations in aid; (2) the removal of the inconsistencies now existing in the distribution of charges between the Consolidated Fund services and the supply services; and (3) the requirement that the Comptroller and Auditor General, in addition to submitting his technical reports on appropriation and other accounts, shall prepare and lay before Parliament a general report on the audited receipts and expenditures of the Government as a whole. Such a report would present expenditures primarily by organization units, but it might be feasible further to analyze the figures from the functional and other points of view. This report, in a word, would do for the real income and expenditure of the Government what the "Finance Accounts" report does for Exchequer receipts and issues. Thus in the supporting tables of the two basic tables in "Finance Accounts" we find the analyses of: Income according to sources from which derived; expenditures for Consolidated Fund services, in sufficient detail to show individual salaries and pensions constituting a charge upon the fund; expenditures for supply services itemized by vote; the composition of the public debt; other liabilities of the Government; and realizable assets of the Government. Such information and analyses for the material in the general report of audited receipts and expenditures would be of great practical value. 


\section{CHAPTER XIII}

\section{THE BUDGET}

Financial Statement 1914-1915, Showing Revenues and Expenditures as Laid before the House of Commons by the Chancellor of the Exchequer when Opening His Budget, May 4, 1914; Financial Statement 1914-1915, Explaining the Proposals Made by the Chancellor of the Exchequer in His Financial Statement on Monday, May 4, 1914; Budget Speech of the Chancellor of the Exchequer; Lack of Any General, Comprehensive Budgetary Statement.

It may be thought remarkable that in a description of the financial administration of a country which, above all others, is noted for its budget system, no mention should be made of its budget until the description is practically completed. That this has been the case has been due to the fact that a budget, as we have pointed out in our analysis of the problem of financial administration, is not so much one of the distinct operations which have to be performed in administering the financial affairs of a government, as the means through which these several operations are correlated and brought under survey at one time to the end that their relations and bearings one upon the other may be made apparent. It follows from this that it is not feasible to consider the nature and rôle of a budget in any given system until the character of the several operations which it is the function of a budget to bring into adjustment is known.

Without attempting to define accurately the term "budget," for it is one which is used with many different meanings, we may say that the idea underlying the conception of a budgetary, as opposed to a non-budgetary, system is that in the former the effort is made, by those who are responsible for initiating financial measures, to consider both sides of the national ac- 
Distinction between Budgetary and NonBudgetary Plan

count at one and the same time, or at least in their relations to each other, and to place them before the legislative branch where appropriations are requested, while, in the latter, no such attempt is made. It is of the essence of the budgetary system that the fund raising and granting authority shall be presented with a balanced statement of estimated receipts and expenditures to the end that it may see whether there is a prospective deficit to be provided for or a surplus which may be applied in the way of reduction of the national debt or for some other purpose, or avoided by remission of taxation.

In the preceding chapters we have pointed out and described the several documents through which Parliament is placed in possession of detailed information regarding the resources and liabilities, the receipts and expenditures, and the estimated needs of the Government for the year to come. It now remains for us to consider the means employed by the Ministry in bringing together the information so imparted and, on its basis, of formulating a financial program for the year; in other words, of preparing and laying before Parliament a budget.

A study of this feature of the financial system of Great Britain shows that use for this purpose is made of three separate documents, the titles of which, if we take the year I9I4r9I 5 as an example, are as follows:

I. Financial Statement I9I4-I9I5: Statement of Revenues and Expenditures as Laid before the House by the Chancellor of the Exchequer when opening the Budget, May 4, I9I4.

2. Budget Speech of the Chancellor of the Exchequer, May 4, I9I4.

3. Financial Statement 19I4-19I 5: Statement Explaining the Proposals Made by the Chancellor of the Exchequer in His Financial Statement on Monday, May 4, I9I4.

The Budget Though not so designated popularly, this statement constitutes a Summary Statement in effect the real budget: the other two statements are but explanatory of the financial program here outlined. Accord256 


\section{THE BUDGET}

ing to the Memorandum on the English Financial System, prepared by the Treasury, to which allusion has several times been made, "an annual statement, partaking of the nature of a budget, has been made in the House of Commons yearly since the Revolution (I688) or for over two hundred years. But for many years they were not of the complete and elaborate character which now distinguishes them; while the fact that for many years speeches were not reported makes it difficult to estimate the value of them. The phrase mentioned above that the Chancellor of the Exchequer 'opens the budget' was in force soon after I750." 1

The statement for the year I9I4-rgi 5 covers but 7 pages. The importance of this document warrants our reproducing it in full, in order that an opportunity may be given to observe its general scope and to appreciate fully the character of the items which are included in it.

Financial Statement 1914-1915: Statement Explaining the Proposals Made by the Chancellor of the Exchequer in His Financial Statement on Monday, May 4, I9I4. It will be noted that in the financial statement submitted May 4, a copy of which has been reproduced on pages 258-264, the Chancellor of the Exchequer mentions in the table giving estimated revenues for I9I4-I9I 5 certain items of income to be derived through a modification of the existing system of taxation. The present statement has for its purpose to give the details of the modification of rates there proposed and the manner in which the increased burden 'of taxation will be distributed among the different classes of taxpayers. The statement is very brief, being but six pages, and contains nothing in the way of argument in favor of the changes proposed. It is difficult to see why this elaboration of the figures given in the first statement was not made a part of that statement instead of being issued as a separate document.

${ }^{1}$ The word "budget" is derived from the French word "bougette," a derivative of "bouge," a leather bag containing papers or accounts. 
Table I. Showing How the Amount Issued from the Exchequer to MEET THE EXPENDITURE IN 1913-1914 CoMpares with THE ESTIMATED EXPENDITURE

\begin{tabular}{|c|c|c|c|c|}
\hline \multirow[t]{2}{*}{ - } & \multicolumn{4}{|c|}{ I913-I4 } \\
\hline & $\begin{array}{l}\text { Total } \\
\text { Expenditure } \\
\text { provided } \\
\text { for in the } \\
\text { Budget }\end{array}$ & $\begin{array}{c}\text { Additional } \\
\text { Expenditure } \\
\text { for which } \\
\text { Supplemen- } \\
\text { tary Estimates } \\
\text { were } \\
\text { presented }\end{array}$ & $\begin{array}{c}\text { Total } \\
\text { Estimated } \\
\text { Expenditure }\end{array}$ & $\begin{array}{c}\text { Amount } \\
\text { issued } \\
\text { to meet } \\
\text { Total } \\
\text { Expenditure }\end{array}$ \\
\hline I. Consolidated Fund Services & & $f$ & $f$ & $f$ \\
\hline $\begin{array}{l}\text { National Debt Services: } \\
\text { Inside the Fixed Debt Charge: } \\
\text { Interest and Management.. } \\
\text { Repayment of Capital..... }\end{array}$ & $\begin{array}{r}\infty, 944,000 \\
7,556,000\end{array}$ & $\ldots \ldots \ldots \cdots$ & $\begin{array}{r}16,944,000 \\
7,556,000\end{array}$ & $\begin{array}{r}16,894,000 \\
7,606,000\end{array}$ \\
\hline $\begin{array}{l}\text { Road Improvement Fund............. } \\
\text { Payments to Local Taxation }\end{array}$ & $\begin{array}{r}24,500,000 \\
1,340,000\end{array}$ & $\ldots \ldots \ldots \cdots$ & $\begin{array}{r}24,500,000 \\
1,340,000\end{array}$ & $\begin{array}{r}24,500,000 \\
1,395,000\end{array}$ \\
\hline $\begin{array}{l}\text { counts, \&c } \\
\text { Other Consolidated Fund Services.... }\end{array}$ & $\begin{array}{l}9,665,000 \\
1,704,000\end{array}$ & $\cdots \cdots \cdots \cdots$ & $\begin{array}{l}9,665,000 \\
1,704,000\end{array}$ & $\begin{array}{l}9,734,000 \\
1,694,000\end{array}$ \\
\hline $\begin{array}{l}\text { Total Consolidated Fund Serv- } \\
\text { ices...................... }\end{array}$ & $37,209,000$ & .......... & $37,209,000$ & $37,323,000$ \\
\hline II. Supply Services & & & & \\
\hline 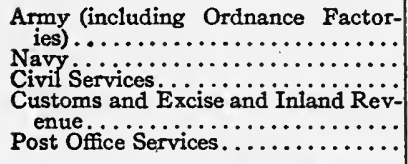 & $\begin{array}{r}28,235,000 \\
46,309,000 \\
54,988,000 \\
4,533,000 \\
24,366,000\end{array}$ & $\begin{array}{r}196,000 \\
2,500,000 \\
675,000 \\
\ldots \ldots \ldots \ldots \\
\ldots \ldots \ldots\end{array}$ & $\begin{array}{r}28,431,000 \\
48,809,000 \\
55,663,000 \\
4,533,000 \\
24,366,000\end{array}$ & $\begin{array}{r}28,346,000 \\
48,833,000 \\
53,901,000 \\
4,483,000 \\
24,607,000\end{array}$ \\
\hline Total Supply Services. & $158,431,000$ & $3,371,000$ & $161,802,000$ & $160,170,000$ \\
\hline Grand Total............. & $195,640,000$ & $3,371,000$ & $199,011,000$ & $197,493,000$ \\
\hline
\end{tabular}

In order to show the entire expenditure for which the State was responsible in 1913-I4. there has to be added the expenditure chargeable to Capital Account as given in the following statement:

I. Expenditure chargeable against Revenue, as in above table.. $197,493,000$

II. Expenditure chargeable against Capital, viz.:-

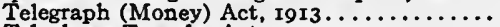
Telephone Transfer Act, Ig I I.............. Post Office (London) Railway Act, Igr $3 \ldots . .$. Land Registry (New Buildings) Act, I900....

£.

90,000

*4,319,000

7,000

10,000

Total

$\frac{4,426,000}{201,919,000}$

* Includes $£ .709,000$ in payment of the balance of the purchase money of the National Telephone Company's undertaking. Payment of $£ .380,000$ of that sum was made by an issue to the Company of Exchequer Bonds of an equivalent amount. 
Table II. Showing How the Revenue in 19I3-I4 Compares with the Budget Estimate and with the Revenue of the Previous YEAR, 1912-I3

\begin{tabular}{|c|c|c|c|c|}
\hline $\begin{array}{c}\text { Receipts in } \\
1912-13\end{array}$ & & $\begin{array}{c}\text { Budget } \\
\text { Estimate for } \\
1913^{-14}\end{array}$ & $\begin{array}{l}\text { Receipts in } \\
1913-14\end{array}$ & $\begin{array}{c}\text { Receipts, } \\
\text { more }(+) \\
\text { or less }(-) \\
\text { than Budget } \\
\text { Estimate }\end{array}$ \\
\hline$£$. & & $£$. & $£$. & $£$. \\
\hline $33,485,000$ & Customs......... & $35,200,000$ & $35,450,000$ & $+250,000$ \\
\hline $38,000,000$ & Excise. & $38,850,000$ & $39,590,000$ & $+740,000$ \\
\hline $25,248,000$ & Estate, \&c., Duties....... & $26,750,000$ & $27,359,000$ & $+609,000$ \\
\hline I0,059,000 & Stamps. . & $9,800,000$ & $9,966,000$ & $+166,000$ \\
\hline 700,000 & Land Tax. & 700,000 & 700,000 & $\cdots$ \\
\hline $2,000,000$ & House Duty... & $2,000,000$ & $2,000,000$ & \\
\hline $41,206,000$ & Income Tax. . & $42,700,000$ & $43,929,000$ & $+I, 229,000$ \\
\hline $3,600,000$ & Super-Tax... & $3,250,000$ & $3,320,000$ & $+\quad 70,000$ \\
\hline 455,000 & Land Value Duties... & 750,000 & 715,000 & 35,000 \\
\hline I $54,753,000$ & Total Receipts from Taxes $£$ & $160,000,000$ & $163,029,000$ & $+3,029,000$ \\
\hline $20,300,000$ & Postal Service.. & $2 I, 125,000$ & $21,190,000$ & $+65,000$ \\
\hline $3,100,000$ & Telegraph Service. & $3,150,000$ & $3,080,000$ & $-70,000$ \\
\hline $5,775,000$ & Telephone Service. . & $6,350,000$ & $6,530,000$ & $+180,000$ \\
\hline 530,000 & Crown Lar & 530,000 & 530,000 & $\ldots$ \\
\hline $1,419,000$ & $\left.\begin{array}{c}\text { Receipts from Suez Canal } \\
\text { Shares and Sundry Loans }\end{array}\right\}$ & $1,370,000$ & $\mathrm{I}, 580,000$ & $+210,000$ \\
\hline $2,925,000$ & Miscellaneous......... & $2,300,000$ & $2,304,000$ & 4,000 \\
\hline $34,049,000$ & $\begin{array}{l}\text { Total Receipts from Non- } \\
\text { Tax Revenue........... }\end{array}$ & $34,825,000$ & $35,214,000$ & $1+3^{89,000}$ \\
\hline I $88,802,000$ & Totals.... & $194,825,000$ & $198,243,000$ & $+3,418,000$ \\
\hline
\end{tabular}


Table III. Giving the Exchequer Balance Sheet of I913-14

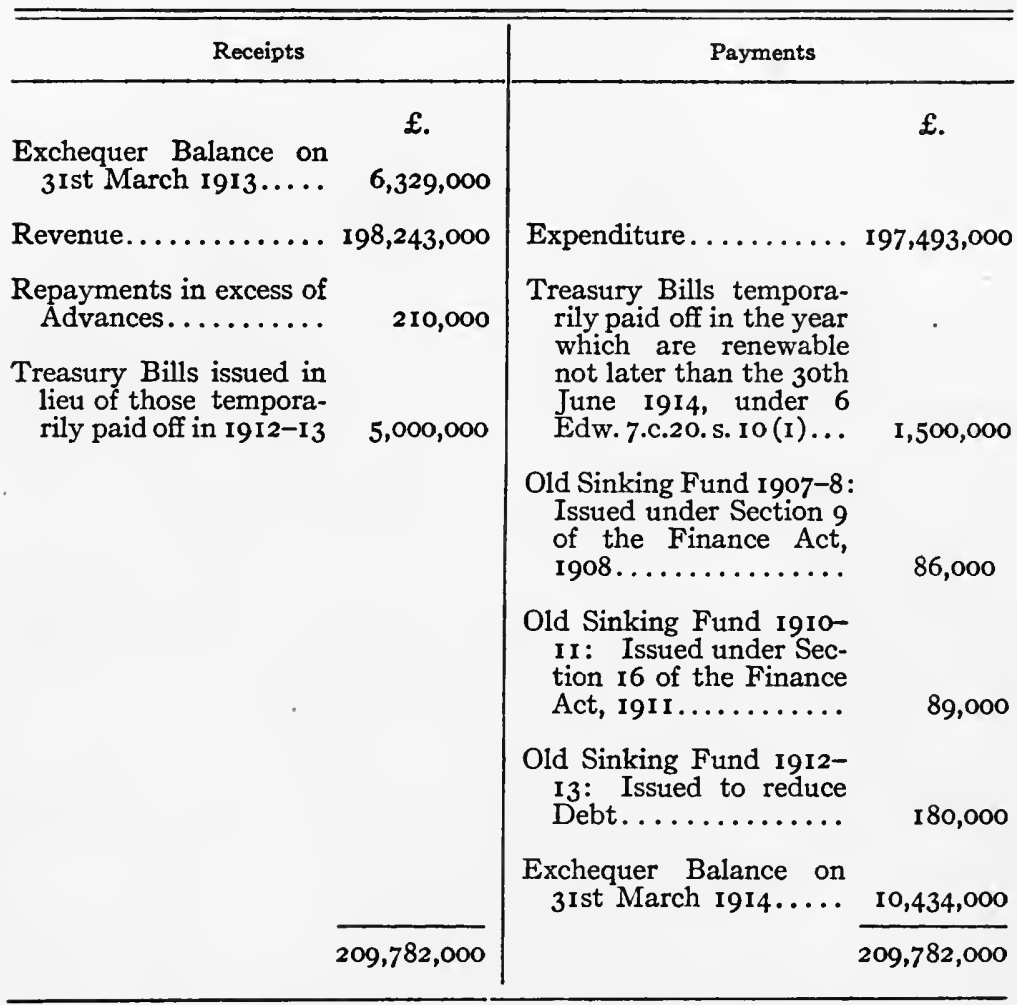


Table IV. Showing How the Estimated Expenditure to be Provided For IN I9I4-I5 COMPARES WITH THE CORRESPONDING Estimated Expenditure a Year Ago

\begin{tabular}{|c|c|c|c|}
\hline Service & $\mathrm{I}_{1} \mathrm{I}_{3}-\mathrm{I}_{4}$ & $1914-15$ & $\begin{array}{c}\text { Estimate } \\
\text { for } 1914-15, \\
\text { more (t) or } \\
\text { less (-) than } \\
\text { I913-14 }\end{array}$ \\
\hline $\begin{array}{l}\text { I. Consolidated Fund Services } \\
\text { National Debt Services: } \\
\text { Inside the Fixed Debt Charge: } \\
\text { Interest and Management...... } \\
\text { Repayment of Capital.......... }\end{array}$ & $\begin{array}{c}£ . \\
\\
\mathbf{1} 6,944,000 \\
7,556,000\end{array}$ & $\begin{array}{c}£ . \\
\text { I6,741,000 } \\
7,759,000\end{array}$ & $\begin{array}{c}£ . \\
-\quad 203,000 \\
+\quad 203,000\end{array}$ \\
\hline 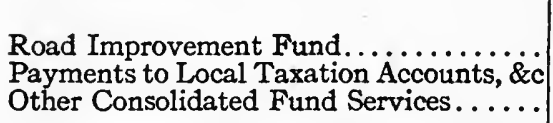 & $\begin{array}{r}24,500,000 \\
1,340,000 \\
9,665,000 \\
1,704,000\end{array}$ & $\begin{array}{r}24,500,000 \\
1,545,000 \\
9,885,000 \\
1,706,000\end{array}$ & $\begin{array}{r}+205,000 \\
+\quad 220,000 \\
+\quad 2,000\end{array}$ \\
\hline Total Consolidated Fund Services. & $37,209,000$ & $37,636,000$ & $+427,000$ \\
\hline 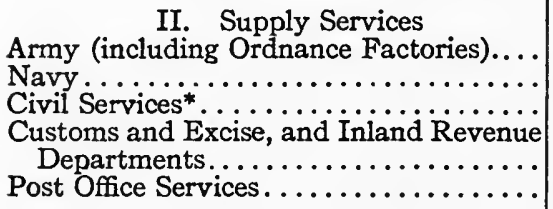 & \begin{tabular}{|r|}
$28,235,000$ \\
$46,309,000$ \\
$54,988,000$ \\
$4,533,000$ \\
$24,366,000$
\end{tabular} \mid & $\begin{array}{r}28,885,000 \\
51,550,000 \\
57,066,000 \\
4,696,000 \\
26,152,000\end{array}$ & $\begin{array}{r}+\quad 650,000 \\
+5,241,000 \\
+2,078,000 \\
+\quad 163,000 \\
+1,786,000\end{array}$ \\
\hline Total Supply Services. & $158,431,000$ & $168,349,000$ & $+9,918,000$ \\
\hline Total. & $195,640,000$ & $205,985,000$ & $+10,345,000$ \\
\hline 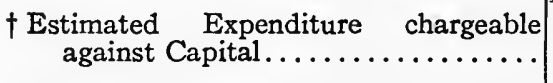 & $3,175,000$ & $5,265,000$ & $+2,090,000$ \\
\hline
\end{tabular}

\begin{tabular}{|c|c|c|c|c|c|}
\hline \multirow{4}{*}{$\begin{array}{l}\text { * Civil Services:- } \\
\text { Public Education...... } \\
\text { Old Age Pensions..... } \\
\text { Labour Exchanges, In- } \\
\text { surance, \&c......... } \\
\text { Other Civil Services... }\end{array}$} & $1913^{-14}$ & I9I4-I5 & \multirow{4}{*}{ 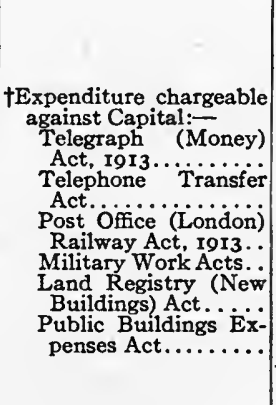 } & I9I3-I 4 & I9I4-I5 \\
\hline & $\begin{array}{c}£ . \\
18,7 \text { I } 7,000 \\
12,600,000 \\
7,499,000 \\
16,172,000\end{array}$ & $\begin{array}{c}£ . \\
\text { I8,978,000 } \\
\text { I2,7 } 10,000 \\
8,312,000 \\
\text { I } 7,066,000\end{array}$ & & $\begin{array}{l}\cdots \ldots \ldots \\
\ddagger 3,000,000\end{array}$ & $\begin{array}{c}£ . \\
\$ 4,500,000 \\
\ldots \ldots \ldots\end{array}$ \\
\hline & $54,988,000$ & $57,066,000$ & & $\begin{array}{r}\cdots \\
65,000 \\
10,000 \\
100,000\end{array}$ & $\begin{array}{r}600,000 \\
65,000 \\
\ldots \ldots \\
100,000\end{array}$ \\
\hline & & & & $3,175,000$ & $5.265,000$ \\
\hline
\end{tabular}

Exclusive of the balance of the purchase money of the National Telephone Company's undertaking.

$\$$ Provisional figure. 
Table V. Giving “Final Balance Sheet," 1914-15,

\section{Estimated Revenue, 1914-15}

Customs

Excise

Estate, \&c. Duties as in Table V

Add:-Proposed revision of duties $(n e t) \ldots \ldots$.

Stamps

Land Tax.

House Duty

Income Tax as in Table $\mathrm{V}$

Add:-Proposed increase of $2 d$. in the $£$ and other alterations (net).

Super Tax as in Table V.

Add:-Proposed alteration of scale

Land Value Duties.

Total Receipts from Taxes

Postal Service.

Telegraph Service.

Telephone Service

Crown Lands.

Receipts from Suez Canal Shares and Sundry Loans.

Miscellaneous.

Total Receipts from Non-Tax Revenue....

Total Revenue.

£.

$45,250,000$

$5,500,000$

$50,750,000$

$3,300,000$

$2,500,000$

$5,800,000$

725,000

$£_{173,675,000}$

$21,750,000$

3,100,000

$6,900,000$

530,000

I, 370,000

2,130,000

$£_{35,780,000}$

$£ 209,455,000$

Borrowings to meet expenditure chargeable against Capital....£ $5,265,000$ 
as Proposed by the Chancellor of the Exchequer

Estimated Expenditure, 1914-15

I. Consolidated Fund Services

National Debt Services:

Interest and Management...............

Repayment of Capital as in Table IV . ........

Deduct:-Proposed reduction of Sinking Fund.......................

Road Improvement Fund ..................

Payments to Local Taxation Accounts, \&c.........

Other Consolidated Fund Services..............

Total Consolidated Fund Services........

$£$.

$7,759,000$

$1,000,000$

$£$.

$16,741,000$

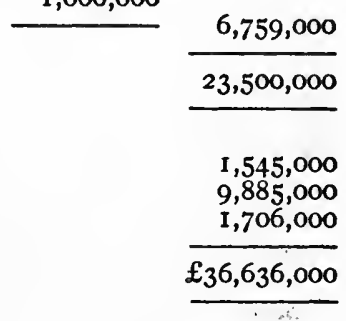

$28,885,000$

5I,550,000

$£$.

$57,066,000$

$\mathrm{I}, 000,000$

586,000

$2,432,000$

$61,084,000$

Customs and Excise, and Inland Revenue Departments, as in Table IV.

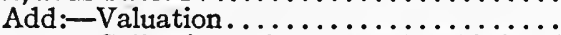

Collection of proposed additional duties.

$$
\begin{array}{r}
4,696,000 \\
80,000 \\
45,000
\end{array}
$$

$4,821,000$

Post Office Services as in Table IV ............

Add:-Proposed increase to low-wage employees.

$26,152,000$

75,000

Total Supply Services.............

Total Expenditure................

Balance.......................

Total. ..................... 


\section{BRITISH FINANCIAL ADMINISTRATION}

Table VI. Showing How the Estimated Receipts in I9I4-I5 from Revenue and From Borrowings to MeEt Capital Expenditure COMPARE WITH THE CORRESPONDING RECEIPTS IN I9I3-I4

(On Basis of Existing Taxation)

\begin{tabular}{|c|c|c|c|}
\hline & $\begin{array}{l}\text { Receipts in } \\
1913-14\end{array}$ & $\begin{array}{c}\text { Estimate } \\
\text { for I9I4-15, } \\
\text { on } \\
\text { basis of } \\
\text { existing } \\
\text { Taxation }\end{array}$ & $\begin{array}{c}\text { Estimate } \\
\text { for I914-15, } \\
\text { more (+) or } \\
\text { less (-) than } \\
\text { Receipts in } \\
\text { I913-14 }\end{array}$ \\
\hline 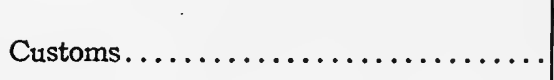 & $\stackrel{£ .}{35,450,000}$ & $\begin{array}{c}£ . \\
35,350,000\end{array}$ & $\begin{array}{l}£ . \\
-\quad 100,000\end{array}$ \\
\hline Excise.... & $39,590,000$ & $39,650,000$ & $+60,000$ \\
\hline Estate, \&c. Duties. . . . . . . & $27,359,000$ & $28,000,000$ & $+641,000$ \\
\hline Stamps..... & $9,966,000$ & $9,900,000$ & $-\quad 66,000$ \\
\hline Land Tax........ & 700,000 & 700,000 & $\ldots$ \\
\hline House Duty. & $2,000,000$ & $2,000,000$ & $\cdots$ \\
\hline Income Tax.... & $43,929,000$ & $45,250,000$ & $+1,321,000$ \\
\hline Super Tax. . & $3,320,000$ & $3,300,000$ & $-\quad 20,000$ \\
\hline Land Value Duties. . & 715,000 & 725,000 & $+\quad 10,000$ \\
\hline Total Receipts from Taxes...... £ & $163,029,000$ & $164,875,000$ & $+1,846,000$ \\
\hline Postal Service. . & $21,190,000$ & $21,750,000$ & $+560,000$ \\
\hline Telegraph Service.......... & $3,080,000$ & $3,100,000$ & $+20,000$ \\
\hline Telephone Service. & $6,530,000$ & $6,900,000$ & $+370,000$ \\
\hline Crown Lands. . & 530,000 & 530,000 & $\ldots \ldots \ldots$ \\
\hline 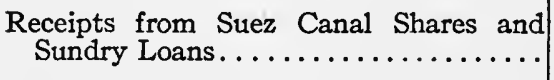 & $1,580,000$ & $I, 370,000$ & $-210,000$ \\
\hline Miscellaneous... & $2,304,000$ & $2,130,000$ & $-\quad 174,000$ \\
\hline $\begin{array}{l}\text { Total Receipts from Non-Tax Rev- } \\
\text { enue............ }\end{array}$ & $35,214,000$ & $35,780,000$ & $\pm 566,000$ \\
\hline Total Revenue...... & $198,243,000$ & $200,655,000$ & $+2,412,000$ \\
\hline $\begin{array}{c}\text { Borrowings to meet Expenditure } \\
\text { chargeable against Capital...... }\end{array}$ & ${ }^{*} 3,7$ I 7,000 & $5,265,000$ & $+\mathrm{I}, 548,000$ \\
\hline
\end{tabular}

* Exclusive of the sum required to complete the purchase of the National Telephone Company's undertaking (See note * on table? I). 
Budget Speech of the Chancellor of the Exchequer. We have stated that the Financial Statement constitutes in effect the budget; certainly it is the document in which a balanced statement of estimated receipts and expenditures is presented together with an indication of the financial proposals of the ministry. Oddly enough, however, the term "budget" is never applied to this statement, but is reserved for the speech which the Chancellor of the Exchequer makes in laying this statement before the House. Thus the Memorandum on the English Financial System says:

"The English budget is merely the speech of the Chancellor of the Exchequer when, soon after the close of the financial year, which is on the 3 rst of March, he lays before the House of Commons the financial result of the year just expired, the estimates of income and expenditure for the year just commencing, and proposals for an increase or diminution of taxation, or other changes in financial administration, which the Government recommended to the approval of Parliament. This speech is not officially published. It is, in fact, only to be found in the pages of 'Hansard's Parliamentary Debates,' an unofficial publication which reports every speech delivered in Parliament. The speech is necessarily but a summary of the figures of the year under consideration and in this it differs widely from the Budget as generally understood abroad; viz., a large volume giving in great detail the estimated income and expenditure of the year to which it applies."

As indicated in this quotation the speech by the Chancellor of the Exchequer is far from a general analysis of the financial history of the year just closed or even a detailed consideration of the expenditure program of the Government for the year to come. Indeed, the whole question of expenditure, except as it may involve certain large features of public policy, is 
English

Budget

Deals

Primarily

with

Revenues
The Historic Background

almost wholly ignored. In the United States and in Europe one thinks of the budget primarily as a document through which a program of expenditures is laid before the appropriating authority. So much is this the case that the term "budget," more often than not, is employed as synonymous with that of estimates of expenditures. Just the contrary is the case in England. There the budget is the document or speech through which the finance minister outlines the policy of the Government in respect to revenues-the estimates of expenditure having already been laid before Parliament and considered in Committee of the Whole. One can not possibly understand the significance of the English budgetary procedure until he appreciates the fact that the interest of Parliament and the people centers on the receipt and not on the expenditure side of the budget. The presentation of the Financial Statement and the delivery of the budget speech of the Chancellor of the Exchequer are anxiously awaited, and when given arouse great interest, not because they will throw any light upon the proposals of the Ministry in respect to expenditures, but because they will reveal what changes are proposed in the system by which the revenues of the Government are obtained. The formal statement of the Chancellor of the Exchequer thus forecasts the nature of the revenue or finance act rather than that of the appropriation act.

This has been so almost from time immemorial. The struggle of the House to control the public purse has been one to control the power of the Crown to impose taxation. rather than the power to expend money. All of its efforts were directed to the establishment of the principle that no new burden could be imposed upon the people without its consent. As we have pointed out, it was not until comparatively recent times that Parliament concerned itself with the matter of the expenditure of the funds, the raising of which it had authorized. This spirit prevails at the present time. It is true that Parliament formally appropriates money for meeting public expenses, but this appropriation is made upon the motion 
of the Crown, according to estimates prepared by the latter, under a few general heads and with large powers to effect transfers from one subhead to another. The House has resigned all right itself to propose an expenditure or to increase an item proposed by the Crown. Even its powers of criticism have been reduced to the minimum consistent with their exercise at all.

The expenditure of public moneys is thus treated as a matter pertaining primarily to the Executive. Practically, the legislature has confined its participation in this important governmental act to the requirement that it shall be given full information regarding both what the Executive proposes to do and how these proposals have in fact been carried out. Under these conditions the interest of both the House and the people in the estimates is directed chiefly to the point whether the estimates as a whole are of such a character as will require the imposition of additional taxes or permit of a reduction of those already in force.

In this withdrawal of the matter of appropriations so largely from legislative determination we have one explanation of the fact of interest centering upon the income side of the budget. Another and still more potent reason for this phenomenon consists in the fact that, contrary to the practice prevailing in the National Government of the United States, inRevenue the Variable come, and not expenditure, is the variable element in the budget. In the United States the income of the Government is in general fixed by permanent law. Congress starts from the point that there is a certain sum available for expenditure and proceeds to determine how it shall be spent. In England the contrary is the case. The Government first determines what is the total of expenditure that must be provided for and proceeds to regulate taxation accordingly.

Lack of a General Comprehensive Budgetary Statement. The foregoing is a practical explanation of what, to the commission, seems to be a serious defect in the English budgetary system-the failure to bring together in one coördinated state- 
ment the several reports and documents through which Parliament is given information regarding financial conditions and proposals. The finance accounts and the estimates are, it is true, in the nature of supporting documents to the budgetary statements and speech of the Chancellor of the Exchequer, but they are not made such in form. When it would be a matter of so little trouble to make all of the financial reports which we have described annexes to the budgetary statement and have them all go into Parliament as one consolidated statement, it is difficult to see why it is not done. In particular it is difficult to see why the three statements relative to the budget proposals proper are not issued in one instead of three separate documents. In the same way the Estimates and the appropriation accounts, instead of appearing as separate volumes for the civil services and revenue departments, the Army, and the Navy, should form in each case a single document with parts corresponding to the present division by volumes.

In a way it may almost be said that England has all the elements of a comprehensive budgetary statement with supporting documents, but has failed to bring these elements to-

Different Elements Not Brought Together gether. The work of making such a statement would be largely a matter of compilation, though advantage should be taken of the opportunity to harmonize inconsistencies and, to a greater extent than is now done, to prepare comprehensive statements of receipts and expenditures covering a series of years. 


\section{CHAPTER XIV}

\section{CONCLUSION}

The chief reason for undertaking this inquiry concerning the system of financial administration of Great Britain was that a more detailed knowledge of a system which is generally held to be one of the most efficient that has been devised by any nation for the management of its national finances could not fail to prove of value to the United States in the efforts now being made to put the administration of our own public finances-national, state and local-upon a more satisfactory basis.

While, therefore, it is no part of our purpose to consider specifically the problems of financial reform now under active discussion in the United States, and still less to urge for adoption any particular measure of reform, it is nevertheless thought that a useful purpose would be served by bringing together in a concluding chapter the more significant features of the British financial system as previously considered in detail, pointing out wherein these features differ from American practice and indicating the extent to which they represent principles and procedures which should at least be given careful consideration in any effort looking to the improvement of our present admittedly ineffective method of locating and enforcing responsibility for the manner in which control over the public finances is exercised.

The already considerable literature dealing with the application of budget principles to American financial administration is perhaps sufficient reason for not attempting here any general consideration of the budgetary problem in the United 
States. The valuable and comprehensive contributions which have recently been made to this subject in the reports of President Taft's Commission on Economy and Efficiency, in the publications of the Bureau of Municipal Research of New York, and in various papers published by Dr. F. A. Cleveland, Chairman of the Commission and Director of the Bureau, should be examined by those who are interested in the significance and possible applications of English experience to American problems of financial administration. ${ }^{1}$

1 "The Need for a National Budget," Report of the Commission on Economy and Efficiency, I912, House Document No. 854, 62nd Congress, 2nd session, Washington, pp. 567 .

The recommendations of the Commission concerning content of a budget, its definition and purpose, and method of introduction; part I, historical and descriptive materials relating to present policies in the United States; part II, the constitutional aspects of a national budget; suggested forms of financial statements, estimates and accompanying data; part III, a pro forma budget and supporting documents with classification, and reasons therefor, of expenditures, appropriations and estimates. Appendix material gives answers to questionnaire on budget methods and procedure in 38 foreign countries; bibliography, etc.; also digest of laws governing preparation and submission of estimates, and pertaining to appropriations and allotments, and description of reports at present submitted to Congress by governmental departments.

"A Budget-with Supporting Memoranda and Reports," Message of the President submitting such for the consideration of Congress. Senate Document No. III3, 62nd Congress, $3^{\text {rd }}$ session, Washington, pp. 433 .

The message (44 pages) is an interpretation and argument for "The Budget," corresponding roughly to the budget speech under usual foreign procedure. The budget gives summaries of data showing financial conditions and operating results, summary of estimates, summary of proposed changes in law. Appendices give schedules supporting budget statements; memorandum on organization of a bureau of central administrative control; recommendations of departmental officers; and summary of constructive recommendations culled from annual reports of executive departments.

"The Budget as a Means of Locating Responsibility for Waste and Inefficiency," by Frederick A. Cleveland. Proceedings New York Academy of Political Science, vol. III, No. 2, 1912, pp. I6.

A discussion of what the President is trying to do by way of budget-making for the National Government. Summarizes budget procedure recommended by President 'Taft's Commission on Economy and Efficiency and discusses essential differences between the present and the proposed method.

Municipal Research, monthly periodical issued by the Bureau of 
The prime features of the British system of financial administration may be summarized as follows:

I. The adoption of the principle of a budget. This means the definite acceptance of the principle that all of the financial needs of the government for the period to be financed shall be considered at one and the same time, according to a welldefined plan to the end that the executive, the Parliament, and the people shall all have clearly before them the full purport of the problem as it affects the condition of the treasury,

Municipal Research and Training School for Public Service, 26r Broadway, New York.

Various issues discuss budgets-municipal, state and national, and budgetary procedure. See especially:

No. 57 (January, 1915), "Next Steps in the Development of a Budget Procedure for the City of Greater New York"-a report addressed to the board of estimate and apportionment, New York City, pp. 5-I 42 .

No. 58 (February, 1915)-“A State Budget-Constructive Proposals to Be Submitted to the State Constitutional Convention," by Frederick A. Cleveland, pp. 147-168; also published in Proceedings New York Academy of Political Science, v, I4I-I92; also memorandum on "The Practical Side of Budget Procedure" by Charles D. Norton, pp. I69-172, and appendix to Dr. Cleveland's paper giving illustrations of budget summaries adapted to submission by the executive to the legislative branch of the Government, pp. 173-198.

No. 62 (June, 1915), "Budget Systems-a Discussion Before the New York Constitutional Convention." Contains proposed constitutional amendment to provide a scientific budget system for the state and exposition of the amendment by former Senator John G. Saxe and Dr. Frederick A. Cleveland; also testimony before committees of the Constitutional Convention by Hon. John J. Fitzgerald, chairman of committee on appropriations, House of Representatives, on "American Financial Methods from the Legislative Point of View"; ex-President William H. Taft on "American Financial Methods from the Executive Point of View"; President Frank J. Goodnow, Johns Hopkins University, on "Administration and Financial Methods"; President A. Lawrence Lowell, Harvard University, on "Financial Administration with Special Reference to English Experience." An appendix gives the report of the committee on finance of the convention favoring an executive budget.

No. 69 (January, I9I6), "Responsible Government." A collection of papers and addresses by Dr. Frederick A. Cleveland on: "Defects in Our Constitutions"; "Responsible Leadership-an Essential to Efficient Democracy"; "Visible vs. Invisible Government"; "The Budget Idea in the United States" (also published in the Annals of the American Academy of Political and Social Science, November, 1915); and a memorial addressed to the legislature of New York, 
present and prospective. This means that Parliament, before taking final action, requires that there shall be prepared and presented to it a series of balanced statements showing the resources and liabilities of the government, receipts and expenditures in the past and estimated receipts and expenditures for the future. These data are classified and exhibited in comparative statements so that their significance for the problem of providing for the financial needs of the future may be plainly apparent.

2. The adoption of the principle that the preparation and submission of this definite financial plan or proposal with supporting details of information devolve upon the executive. This means that the executive branch of the government has placed upon it the obligation of bringing before the fundraising and fund-granting authority, in one comprehensive statement, a definite financial and work program, which shall include an estimate of the cost of carrying on each activity

signed by the trustees of the Bureau of Municipal Research, together with correspondence with the Governor of New York concerning his budget proposal to the legislature of igi6. Appendix contains draft of proposed amendment of the legislative and executive laws of New York and a list of bills introduced in I9I5 calling for expenditures of money, together with a list of those passed by one house and sent to the other for concurrence, and a brief abstract of each bill reported.

No. 70 (February, I9ז6), "Budget Legislation in Two States," pp. 102. Introduction on "The Measuring Stick of Democracy"; part I on Financial Legislation in New Jersey; part II, Financial Legislation in New York; with discussion of various proposals before the legislatures of I9I6 in both New York and New Jersey.

No. 72 (April, 1916), "The History of Appropriations in the Legislative Session of I916, New York State," pp. I34. A detailed study of all the financial proposals before the legislature of that year and what was done with them, together with copious quotations from legislative debates and critical comments by Dr. Burl E. Shultz, who followed these sessions at Albany and prepared the report upon them.

No. 73 (May, I9r6), "Three Proposed Constitutional Amendments for Control of the Purse," pp. 86. Contains discussion of executive vs. legislative budget; alternatives before Governor Whitman in New York; the Maryland proposed constitutional amendment for an executive budget; the proposed New York constitutional amendments; together with certain open letters addressed to the legislature by the New York Bureau of Municipal Research. 


\section{CONCLUSION}

and a plan for raising the necessary funds for the definite and stated period to be financed.

3. The adoption of the principle of control over the executive through the grant to Parliament, and especially to the opposition in that body, of an opportunity to subject such report of past operations and of proposals for the future to critical examination. This means that the executive shall be placed where at all times it is compelled to answer all questions, to explain and defend before all the members, in committee of the whole, all of its acts past and proposed, while the details of estimates are being initially considered.

4. The adoption of the principle that, while Parliament shall thus be given full and detailed information regarding financial transactions, and be afforded adequate opportunity to criticize such action and proposals, responsibility not only for the proposal as initially submitted, but for every change made in it as the result of discussion shall normally rest with the executive. The adoption of this principle is but putting into effect the more general principle of responsible government that the executive-the ministry in power, is responsible for leadership both in planning and in executing plans having to do with the actual conduct of the financial and business affairs of government and that the function of Parliament is restricted to that of seeing that this responsibility for leadership is not shifted or confused. This principle is put into effect through the adoption by Parliament of rules of procedure which expressly prohibit all motions looking to the increase of proposals for expenditures as brought forward by the executive and the observance of conventions which in effect restrain it from making any change of a material character in the financial program as formulated by the executive, whether, in the way of increases or decreases.

5. The no less definite adoption of the principle that, though the determining voice in respect to the preparation 


\section{BRITISH FINANCIAL ADMINISTRATION}

of a plan for raising and expending all revenues lies with the executive, the latter must wait on approval by Parliament, and after approval shall render a rigid accounting to Parliament in respect to the manner in which authorizations granted are carried out. This is secured by the establishment of a system of accounting and reporting which gives to Parliament and the people full information regarding all financial transactions in an exceptionally clear and detailed manner.

6. The adoption of the principle of a parliamentary audit of receipts and expenditures as a means of exercising rigid scrutiny over the manner in which authorizations are carried out. This is secured by making provision for the audit of all accounts by a Comptroller and Auditor General, who is an officer of Parliament and reports directly to it. This officer, though appointed by the executive, enjoys complete independence due to the fact that he has had conferred upon him the status of a judicial officer, that his salary is a direct charge upon the Consolidated Fund, that he holds office during good behavior and that he can be removed from office only in the same manner as is provided for the removal from office of judicial officers.

7. The adoption of the principle that the reports of this officer shall in fact be subjected to careful examination and scrutiny by members of Parliament. This is secured through the establishment of a standing committee on public accounts of the House of Commons, the chairman of which is taken from the opposition ${ }^{1}$ having for its sole function the examination and report upon all transactions regarding which any question of propriety can be raised. This committee has the power to take testimony and to bring before it all officers of the government having knowledge of the facts to be inquired into. It furnishes thus an effective means by which Parliament, making use of the report

${ }^{1}$ In only one year since 1866 has Parliament taken the chairman of this committee from the majority, and that was the year 1869 . 
made to it by its officer, the Comptroller and Auditor General, can examine into all financial transactions of the executive.

8. The adoption of the principle that the work of exercising an immediate and direct control over the preparation of estimates and expenditure of funds shall be performed by a special organ which shall in effect act in this capacity as an agent of Parliament. This organ, known as the Treasury Department, is in principle not itself an operating department. It is not coördinate with such departments, but has a position superior to them, which is well recognized and established.

9. The adoption of the principle that in making appropriations a clear distinction shall be made between: (I) Appropriation heads, (2) appropriation subheads, and (3) supporting details. The purpose of making these distinctions is that of harmonizing the desirability, on the one hand, of prescribing in all practical detail the purposes for which funds shall be granted, and, on the other, of permitting the maximum flexibility in the actual expenditure of funds that is consistent with adequate control. This is secured by providing that the details of expenditures set forth in the supporting tables are incorporated in the Estimates for purposes of information only; that the amounts carried by the subheads of appropriations shall be deemed to be in the nature of allotments subject to change by the effecting of transfers of money from one subhead to another; and that only the totals carried by the appropriation heads or "votes," as they are called, shall be in the nature of definite appropriations not subject to change. ${ }^{1}$ Abuse of the power to effect transfers from one subhead to another is abundantly safeguarded by the provisions; that no transfers shall be made except upon the approval of the Treasury; that account of expenditures shall

1 To this latter statement there is the exception that transfers between appropriation heads may be effected in the case of the Army and Navy votes. 


\section{BRITISH FINANCIAL ADMINISTRATION}

be kept according to sub-appropriation heads; and that the report of expenditures shall show clearly the extent to which this power to make transfers has been exercised.

ro. The adoption of the principle that the expenditure of appropriations is not mandatory. Under the British system appropriations are mere grants to the executive, and the latter is held responsible for the manner in which this discretion to make use of funds is exercised. To ensure that the funds granted will in fact be only expended as public needs require, the principle is firmly established that no funds shall be expended except upon the authorization of the Treasury.

It is hardly necessary to point out how radically this system differs from American practice. Scarcely one of these fundamental principles of financial procedure finds expression in our own system. The basic principle underlying the use of a budget as the central instrument for correlating all of the financial transactions of the government so that the whole problem of financing the government may be considered at one and the same time, is hardly understood in this country, much less acted upon. Though the executive is called upon to keep account of receipts and expenditures, to make reports and to submit estimates, the technical problem of having them so kept and submitted as to constitute a comprehensive report of past transactions and a work program for the future has not been satisfactorily worked out. The result is that Congress does not get before it a statement of the financial and work program of the executive in such a form that it can clearly see its full purport. The fact that Congress does not get the information to which it is entitled is evidenced by the necessity that its committees, having the consideration of appropriation bills, is under of holding elaborate hearings for the purpose of securing information regarding estimate proposals. Most important of all, Congress, and not the executive, is deemed to be the body that should formulate the definite program of receipts and expenditures. The reports and 
estimates that are submitted to it are not looked upon as an executive program, but rather as data to enable Congress to perform its function as a program-framing body. The audit of accounts, instead of being made by an officer of the body granting the funds, is made by an officer of the branch of the government whose operations are to be passed upon. Though early provision was made by the House for committees on expenditures in the executive departments, these committees have never attempted to make any thorough or systematic examination of the financial transactions of the executive as revealed in the audited accounts. Congress thus has no effective machinery for the exercise of supervision and control over the manner in which the executive performs its duties such as is possessed by the British Parliament in its Comptroller and Auditor General and its standing committee on public accounts. In respect to the granting of funds, the general principle is followed that all appropriations are morally, if not legally, obligatory, that they represent an order given by Congress to the executive, and that it is the duty of the latter to act upon such order. The result is that the executive feels called upon to expend all the funds voted to it whether it deems such expenditure to be wise or not. Nothing approaching the British system of securing flexibility in the expenditure of funds by distinguishing between appropriation heads and subheads and of permitting of transfers to be effected between subheads is to be found in the American system. Finally, there is totally lacking in the National Government any organ having the duty of exercising a day to day supervision and control over the financial transactions of the Government, such as the British Government possesses in its Treasury Department.

In both the detailed description of the British financial system and in the foregoing enumeration of its leading features the effort has been made to do two things: To make known the fundamental principles upon which this system rests and to bring out clearly the specific means employed in putting these 
principles into execution. The importance of considering both of these factors cannot be overemphasized. In the movement constantly gaining force for the adoption in the United States of the budgetary principle by all public bodies, there has been too little appreciation of the administrative features of the problem. There is no more important lesson to be deduced from the foregoing study than that the success with which the British system works is in large part due to the effectiveness with which provision has been made for an administrative machinery and procedure devised for the accomplishment of the end sought.

Take for example the crucial point of the British system, that represented by the exercise by the executive of the controlling voice in the formulation and determination of the financial and work program. Can anyone for a moment suppose that Parliament would acquiesce in any such arrangement were not provision at the same time made, in the Treasury Department, in the office of the Comptroller and Auditor General and in the standing committee on public accounts of the House of Commons, for organs superior in status and authority to those of the operating or spending departments proper through which an effective supervision and control over all administrative acts might be maintained? Or, again, is it at all likely that a scheme of appropriation would be adopted under which definite appropriations are made only under a relatively few main heads and a large liberty is permitted for the transfer of funds from one subhead to another, were not provision at the same time made that this discretion in respect to the expenditure of funds should be subject to the control of a department whose function it is to act as the general business manager and agent of Parliament to see that all powers granted are properly exercised?

The importance of these considerations must be apparent in all efforts looking to the adoption of the budgetary system in the United States. It would be futile to attempt to persuade Congress and the state legislatures to surrender the 


\section{CONCLUSION}

authority which they now exercise over the appropriation of funds in favor of an executive determination unless coupled with this demand is a proposal to set up organs and a procedure which will ensure a more effective supervision and control over the financial acts of administrative officers than is now secured by these bodies seeking to act directly. Moreover, it is almost certain that unless provision is made in this way for the exercise of a superior direction, supervision and control, that the system of an executive budget, if it did not develop abuses equal to those of the existing system, would certainly fail to give the results expected of it.

Another matter of great importance is the making of a clear distinction between the operations of formulating the budgetary program and of acting upon such program. It is one thing to maintain that the executive shall draft and lay before the legislature a comprehensive report of financial transactions in the past and a program for operations in the future, and quite another to hold that no material change in the latter shall be made by the body to which it is submitted. One can quite well endorse the first without acquiescing in the second. Indeed, the need for the submission by the executive of a proper statement of financial operations, past and proposed, is, if possible, even greater under the system of legislatively determined appropriations than under one of executive determination. As long as the legislature exercises this high power, it is only proper that it should insist that the executive shall place it in possession of all the facts in such a form that it can exercise this power effectively. The demand for an executively formulated budget is thus in no sense a demand that the legislature abdicate any of the powers that it now has over the appropriation of funds. On the contrary, it involves only a demand that the legislature shall be furnished with the means through which its powers may be more effectively exercised.

To recapitulate, it would therefore seem highly desirable to distinguish clearly between the three basic factors of the 
budgetary problem: (I) The formulation of a budget; (2) action upon the budget, and (3) the provision of organs and a procedure through which budgetary control may be secured. As a matter of practical expediency, it would further seem that greater progress in the direction of reform can be anticipated if, for the present, attention is concentrated upon the first and last of these three factors. To neither of these can the most ardent advocate of the system of legislative determination of appropriations find any objection. So great would be the improvement resulting from proper action in respect to these factors that they may well be regarded as necessary intermediate steps before the American public is prepared to pass judgment on the second, which can only arouse intense opposition and thus might jeopardize any progress at all. With the principle of an executively formulated budget and the principle of a proper machinery for exercising budgetary control once firmly established, the basis will be laid for a change in procedure in respect to the second-that having to do with action upon the budget-if such change is then deemed to be desirable. 
APPENDICES 



\section{APPENDIX I}

EXCHEQUER AND AUDIT DEPARTMENTS ACT, I866, AND TREASURY MINUTE THEREON

29 \& 30 Vict. Chapter 39

An Acr to consolidate the Duties of the Exchequer and Audit Departments, to regulate the Receipt, Custody, and Issue of Public Moneys, and to provide for the Audit of the Accounts thereof.

[28th June I866.]

'Whereas it is expedient to consolidate the powers and duties 'of the Comptroller of Her Majesty's Exchequer and of the 'Commissioners for Auditing the Public Accounts, and to unite 'in one department the business hitherto conducted by the sepa'rate establishments under them; and to make other provi'sions for the more complete examination of the public ac'counts of the United Kingdom:' Be it therefore enacted by the Queen's most Excellent Majesty, by and with the advice and consent of the Lords Spiritual and Temporal, and Commons, in this present Parliament assembled, and by the authority of the same, as follows:

I. This Act may be cited for all purposes as the Exchequer and Audit Departments Act, I866.

2. In this Act "the Treasury" shall mean the Commissioners of Her Majesty's Treasury for the time being, or any. two or more of them; "the Bank of England" shall mean the Governor and Company of the Bank of England; "the Bank of Ireland" shall mean the Governor and Company of the Bank of Ireland; "the National Debt Commissioners" shall mean the Commissioners for the Reduction of the National 283 


\section{APPENDIX I}

Debt; "principal accountants" shall mean those who receive issues directly from the accounts of Her Majesty's Exchequer at the Banks of England and Ireland respectively; "subaccountants" shall mean those who receive advances, by way of imprest, from principal accountants, or who receive fees or other public moneys through other channels; "the Secretaries of the Treasury" shall include the Assistant Secretary.

3. At any time within twelve months after the passing of this Act it shall be lawful for Her Majesty, Her heirs and successors, by letters patent under the Great Seal of the United Kingdom, to nominate and appoint the person who shall at that time hold the office of Comptroller-General of the Receipt and Issue of Her Majesty's Exchequer, and Chairman of the Commissioners for Auditing the Public Accounts, to be Comptroller-General of the Receipt and Issue of Her Majesty's Exchequer and Auditor-General of Public Accounts, in this Act referred to as "Comptroller and Auditor-General," and also to nominate and appoint one of the persons who shall at that time hold the offices of Commissioners for Auditing the Public Accounts to be "Assistant Comptroller and Auditor."

The said Comptroller and Auditor-General and Assistant Comptroller and Auditor shall hold their offices during good behaviour, subject, however, to their removal therefrom by Her Majesty, Her heirs and successors, on an address from the two Houses of Parliament; and they shall not be capable of holding their offices together with any other office to be held during pleasure under the Crown or under any officer appointed by the Crown; nor shall they be capable, while holding their offices, of being elected or of sitting as members of the House of Commons; nor shall any peer of Parliament be capable of holding either of the said offices.

4. Her Majesty may, by such letters patent, grant to the persons therein named the following salaries; that is to say,-

To the Comptroller and Auditor-General a salary of two thousand pounds per annum, and to the Assistant 
Comptroller and Auditor a salary of one thousand five hundred pounds per annum; and such salaries shall be charged upon and paid out of the Consolidated Fund of the United Kingdom or the growing produce thereof. It shall be lawful for Her Majesty, Her heirs and successors, by letters patent as aforesaid, to grant to any person who shall have executed the offices of Comptroller and Auditor-General, or Assistant Comptroller and Auditor, on his ceasing to hold such office, an annuity or pension not exceeding one-half of the salary of his office to which he shall have been entitled immediately before he ceased to hold such office, if he shall have held either, or one after the other, of the said offices, or the office of Commissioner of Audit for a period not less than fifteen years, and two-thirds of his said salary if he shall have held either, or one after the other, of the said offices for a period not less than twenty years: Provided always, that no such annuity or pension shall be granted to either of the said officers unless he be sixty years of age at the least, or be afflicted with some permanent infirmity disabling him from the due execution of his office, the same to be distinctly recited in such grant: Provided also, that nothing herein contained shall prevent either of the said officers from receiving, in lieu of such annuity or pension, if he shall so elect, the amount of superannuation allowance to which he would have been entitled in respect of the full period during which he shall have served in the permanent Civil Service of the State under the provisions of the Superannuation Act, I859.

5. On the appointment as aforesaid of a Comptroller and Auditor-General and an Assistant Comptroller and Auditor, the then existing letters patent of appointments of ComptrollerGeneral of the Exchequer and of Commissioners of Audit shall be ipso facto revoked, and the present offices of Comptroller285 
General of the Exchequer and Commissioners of Audit shall be abolished, but the person appointed to be Comptroller and Auditor-General shall have and perform all the powers and duties conferred or imposed on the Comptroller-General of the Exchequer and the Commissioners for Auditing the Public Accounts respectively by any enactments relative to those authorities respectively as far as the same are not repealed or altered by this Act or any other Act of the present session of Parliament; and it shall. be lawful for the Treasury to grant to each of the said Commissioners of Audit whose offices shall be abolished under the provisions of this Act, and who shall not be appointed to either of the said offices of Comptroller and Auditor-General or Assistant Comptroller and Auditor, an annual allowance, by way of compensation, not exceeding the sum charged on the Consolidated Fund as the salary of such Commissioners: Provided always, that any Commissioners who may be in receipt of emoluments exceeding the salary so charged on the Consolidated Fund shall be entitled to receive, in addition to the aforesaid compensation allowance, such proportion of the said emoluments as the Treasury are empowered to grant under the provisions of the Superannuation Act, I859; and such allowances shall be charged upon and paid out of the Consolidated Fund of the United Kingdom or the growing produce thereof.

6. On the death, resignation, or other vacancy in the office of the Comptroller and Auditor-General, or of the Assistant Comptroller and Auditor, Her Majesty, Her heirs and successors, may by letters patent as aforesaid nominate and appoint a successor, who shall have the same powers, authorities, and duties, and who shall be paid the like salary and the like annuity or pension out of the Consolidated Fund.

7. Anything which under the authority of this Act is directed to be done by the Comptroller and Auditor-General may, in his absence, be done by the Assistant Comptroller and Auditor, except the certifying and reporting on accounts for the House of Commons. 
8. The Treasury shall from time to time appoint the officers, clerks, and other persons in the Department of the Comptroller and Auditor-General, and Her Majesty by Order in Council may from time to time regulate the numbers and salaries of the respective grades or classes into which the said officers, clerks, and others shall be divided.

9. The Comptroller and Auditor-General shall have full power to make from time to time orders and rules for the conduct of the internal business of his department, and to promote, suspend, or remove any of the officers, clerks, and others employed therein; and to prescribe regulations and forms for the guidance of principal and of sub-accountants in making up and rendering their periodical accounts for examination: Provided always, that all such regulations and forms shall be approved by the Treasury previously to the issue thereof.

Io. The Commissioners of Customs, the Commissioners of Inland Revenue, and the Postmaster-General shall, after deduction of the payments for drawbacks, bounties of the nature of drawbacks, repayments, and discounts, cause the gross revenues of their respective departments to be paid, at such times and under such regulations as the Treasury may from time to time prescribe, to accounts to be intituled "The Account of Her Majesty's Exchequer" at the Bank of England and at the Bank of Ireland respectively, and all other public moneys payable to the Exchequer shall be paid to the same accounts, and accounts of all such payments shall be rendered to the Comptroller and Auditor-General daily in such form as the Treasury may prescribe: Provided always, that this enactment shall not be construed to prevent the collectors and receivers of the said gross revenues and moneys from cashing, as heretofore, under the authority of any Act or regulation, orders issued for naval, military, revenue, civil, or other services, repayable to the Revenue Departments out of the Consolidated Fund or out of moneys provided by Parliament. 


\section{APPENDIX I}

I I. All moneys paid into the Bank of England and the Bank of Ireland on account of the Exchequer shall be considered by the Governor and Company of the said banks respectively as forming one general fund in their books; and all orders directed by the Treasury to the said banks for issues out of credits to be granted by the Comptroller and AuditorGeneral, as hereinafter provided, for the public service, shall be satisfied out of such general fund; and with a view to economise the public balances the Treasury shall restrict the sums to be issued or transferred from time to time to the credit of accounts of principal accountants at the said banks, as hereinafter provided, to such total sums as they may consider necessary for conducting the current payments for the public service intrusted to such principal accountants; and the said principal accountants may consider the sums so transferred to their accounts as constituting part of their general drawing balance applicable to the payment of all the services for which they are accountable; but such sums shall be carried in the books of such accountants to the credit of the respective services for which the same may be issued, as specified in such orders: Provided always, that this enactment shall not be construed to empower the Treasury or any authority to direct the payment, by any such principal accountant, of expenditure not sanctioned by any Act whereby services are or may be charged on the Consolidated Fund, or by a vote of the House of Commons, or by an Act for the appropriation of the supplies annually granted by Parliament.

I2. At the close of each of the quarters ending on the thirtyfirst day of March, the thirtieth day of June, the thirtieth day of September, and the thirty-first day of December in every year, the Treasury shall prepare an account of the income and charge of the Consolidated Fund in Great Britain and in Ireland for such quarter, and the charges for the public debt due on the fifth day of April, the fifth day of July, the tenth day of October, and the fifth day of January, shall be included in the accounts of the said charge for the quarters 


\section{APPENDIX I}

ending on the days preceding the latter dates; and a copy of such account shall forthwith be transmitted by the Treasury to the Comptroller and Auditor-General; and if it shall appear by such account that the income of the Consolidated Fund in Great Britain or in Ireland for the quarter is not sufficient to defray the charge upon it, the Comptroller and AuditorGeneral, if satisfied of the correctness of the deficiency, shall certify the amount thereof, to the Bank of England or to the Bank of Ireland, as the case may be, and upon such certificates the said banks shall be authorised to make advances, from time to time, during the succeeding quarter, on the application of the Treasury, by writing, in a form to be from time to time determined by them, to an amount not exceeding in the aggregate the sums specified in such certificates; and all such advances shall be placed to the credit of the Exchequer accounts at the said banks, and be available to satisfy the orders for credits granted or to be granted upon the said accounts by the Comptroller and Auditor-General; and the principal and interest of all such advances shall be paid out of the growing produce of the Consolidated Fund in the said succeeding quarter.

I3. The Comptroller and Auditor-General shall grant to the Treasury from time to time, on their requisitions authorising the same, if satisfied of the correctness thereof, credits on the Exchequer accounts at the Banks of England and Ireland, or on the growing balances thereof, not exceeding the amount of the charge in the aforesaid quarterly account of the income and charge of the Consolidated Fund remaining unpaid.

The Comptroller and Auditor-General shall also grant from time to time to the Treasury, on similar requisitions, supplemental credits for services payable under any Act out of the growing produce of the Consolidated Fund, and not included in the aforesaid quarterly account; and the issues or transfers of moneys required from time to time by the principal accountants to enable them to make the payments 


\section{APPENDIX I}

intrusted to them shall be made out of such credits on orders issued to the said banks, signed by one of the Secretaries of the Treasury, or in their absence by such officer or officers as the Treasury may from time to time appoint to that duty, and in all such orders the services for which the issues may be authorised shall be set forth.

A daily account of all issues or transfers made from the Exchequer accounts, in pursuance of such orders, shall be transmitted by the said banks to the Comptroller and AuditorGeneral.

14. When any sum or sums of money shall have been granted to Her Majesty by a resolution of the House of Commons, or by an Act of Parliament, to defray expenses for any specified public services, it shall be lawful for Her Majesty from time to time, by Her Royal Order under the Royal Sign Manual, countersigned by the Treasury, to authorise and require the Treasury to issue, out of the credits to be granted to them on the Exchequer accounts as hereinafter provided, the sums which may be required from time to time to defray such expenses, not exceeding the amount of the sums so voted or granted.

I5. When any ways and means shall have been granted by Parliament to make good the supplies granted to Her Majesty by any Act of Parliament or resolution of the House of Commons, the Comptroller and Auditor-General shall grant to the Treasury, on their requisition authorising the same, a credit or credits on the Exchequer accounts at the Bank of England and Bank of Ireland, or on the growing balances thereof, not exceeding in the whole the amount of the ways and means so granted. Out of the credits so granted to the Treasury issues shall be made to principal accountants from time to time on orders issued to the said banks, signed by one of the Secretaries of the Treasury, or in their absence by such officer or officers as the Treasury may from time to time appoint to that duty; and the services or votes on account of which the issues may be authorised shall be set forth in such 
orders: Provided always, that the issues for Army and Navy services shall be made under the general heads of "Army" and "Navy" respectively.

A daily account of all issues made from the Exchequer accounts in pursuance of such orders shall be transmitted by the said banks to the Comptroller and Auditor-General.

${ }^{1}$ I6. Within fifteen days after the expiration of the quarters ending on the thirty-first day of March, the thirtieth day of June, the thirtieth day of September, and the thirtyfirst day of December in every year, the Treasury shall prepare an account of the public income and expenditure of the United Kingdom, according to the actual receipt and issue of moneys on the Exchequer accounts at the Bank of England and Bank of Ireland in the twelve months ending on such quarter days respectively; and if there shall appear by such account to be a surplus of income above expenditure, the Treasury shall certify the same to the National Debt Commissioners, and onefourth part of such surplus shall be applicable to the reduction of the national debt as herein-after directed; and the National Debt Commissioners shall publish from time to time in the London Gazette the sum which will be so applied in the ensuing quarter. The Treasury shall cause one-fourth part of such surplus income to be charged on the Consolidated Fund in the quarter succeeding the termination of such account; and the sum so charged shall be issued by the Treasury from time to time in the next ensuing quarter to the National Debt Commissioners, who shall apply the same, during the said quarter, in redeeming funded or unfunded debt, or in repaying to the Bank of England or to the Bank of Ireland any advances made by them, under the provisions of this Act, towards supplying the deficiency of the Consolidated Fund during the said quarter; and all debt so redeemed shall be forthwith cancelled. And a copy of every account prepared by the Treasury as aforesaid, certified by the Comptroller and Auditor-General, shall be laid before the House of

${ }^{1}$ Section 16 is repealed by $38 \& 39$ Vict. c. 45 , s. 6. 


\section{APPENDIX I}

Commons within fifteen days after the expiration of the said quarterly periods, if Parliament be then sitting, or, if not sitting, then within one week after Parliament shall be next assembled.

${ }^{1}$ I 7. All debts accruing due under any contract or lease now or hereafter entered into or taken for the public service, and payable out of the supplies from time to time voted by Parliament to Her Majesty for the public service, in any department for which the payments are made by the Paymaster-General,- shall be discharged and paid in manner following; that is to say, such debts shall be payable on the order of the department, and the payment thereof shall be made by a draft drawn by the Paymaster-General on the Bank of England, according to the course and practice of his office, payable to the persons to whom such debts may be due, or to their agents.

I8. The Treasury may from time to time determine at what banks accountants shall keep the public moneys entrusted to them, and they may also determine what accounts so opened in the names of public officers or accountants in the books of the Bank of England, of the Bank of Ireland, or of any other bank, shall be deemed public accounts; and on the death, resignation, or removal of any such public officers or accountants the balances remaining at the credit of such accounts shall, upon the appointment of their successors, unless otherwise directed by law, vest in and be transferred to the public accounts of such successors at the said banks, and shall not in the event of the death of any such public officers or accountants, constitute assets of the deceased, or be in any manner subject to the control of their legal representatives.

19. It shall be lawful for the Treasury, whenever they shall consider it for the advantage of the public service, to direct that the accounts of any public officer or department, which by any Act or Acts are required to be kept under separate heads at the Bank of England or at the Bank of Ireland, shall

${ }^{1}$ Section 17 is repealed by 52 \& 53 Vict. c. 53 , s. 2. 
be consolidated in such manner as they shall judge most convenient for the public service.

20. It shall be lawful for the Bank of England and Bank of Ireland, at the request of the Treasury, signified by one of their secretaries, for the public convenience, to open and keep accounts of Government stock and annuities in the books of the said banks under the official description of any public officer for the time being without naming him and the dividends on such stock and annuities may from time to time be received, and the stock and annuities, or any part thereof, to the credit of such account may from time to time be transferred by the officer for the time being, holding such office, as if such stock and annuities stood in his own name; and upon the death, resignation, or removal of any such public officer, the stock and annuities standing to the credit of such account, and all dividends thereon, including any dividends not theretofore received, shall become vested in his successor in office, and be receivable and transferable accordingly. And any such public officer in whose official description such Government stock and annuities may be standing may, by letter of attorney, authorise the Bank of England or the Bank of Ireland, or all or any of their cashiers, to sell and transfer all or any part of the stock or annuities from time to time standing in the books of the said banks on such account, and to receive the dividends due and to become due thereon; but no stock or annuities shall be sold or transferred at the said banks under the authority of such general letter of attorney, except upon an order in writing, signed by one of the Secretaries of the Treasury, directed to the proper officers of the said banks.

\section{Appropriation Accounts}

2I. The Treasury shall cause an account to be prepared and transmitted to the Comptroller and Auditor-General for examination on or before the thirtieth day of September in every year, showing the issues made from the Consolidated 


\section{APPENDIX I}

Fund of Great Britain and Ireland in the financial year ended on the thirty-first day of March preceding, for the interest and management of the public funded and unfunded debt, for the Civil List, and all other issues in the financial year for services charged directly on the said fund; and the Comptroller and Auditor-General shall certify and report upon the same with reference to the Acts of Parliament under the authority of which such issues may have been directed; and such accounts and reports shall be laid before the House of Commons by the Treasury on or before the thirty-first day of January in the following year, if Parliament be then sitting, and if not sitting, then within one week after Parliament shall be next assembled.

22. On or before the days specified in the respective columns of Schedule (A) annexed to this Act, accounts of the appropriation of the several supply grants comprised in the Appropriation Act of each year shall be prepared by the several departments, and be transmitted for examination to the Comptroller and Auditor-General and to the Treasury, and when certified and reported upon as herein-after directed they shall be laid before the House of Commons; and such accounts shall be called the "Appropriation Accounts" of the moneys expended for the services to which they may respectively relate; and the Treasury shall determine by what departments such accounts shall be prepared and rendered to the Comptroller and Auditor-General, and the Comptroller and Auditor-General shall certify and report upon such accounts as herein-after directed; and the reports thereon shall be signed by the Comptroller and AuditorGeneral: Provided always, and it is the intention of this Act that the Treasury shall direct that the department charged with the expenditure of any vote under the authority of the Treasury shall prepare the appropriation account thereof: Provided also, that the term "department," when used in this Act in connexion with the duty of preparing the said appropriation accounts, shall be construed as including any 


\section{APPENDIX I}

public officer or officers to whom that duty may be assigned by the Treasury.

23. A plan of account books and accounts, adapted to the requirements of each service in order to exhibit, in a convenient form, the whole of the receipts and payments in respect of each vote, shall be designed under the superintendence of the Treasury; and Her Majesty may from time to time, by Order in Council, prescribe the manner in which each department of the public service shall keep its accounts.

24. An appropriation account of supply grants shall exhibit on the charge side thereof the sum or sums appropriated by Parliament for the service of the financial year to which the account relates, and on the discharge side thereof the sums which may have actually come in course of payment within the same period; and no imprest or advance, of the application of which an account may not have been rendered to and allowed by the accounting department, shall be included on the discharge side thereof.

25. The department charged with the duty of preparing the appropriation account of a grant shall, if required so to do by the Comptroller and Auditor-General, transmit to him, together with the annual appropriation account of such grant, a balance-sheet so prepared as to show the debtor and creditor balances in the ledgers of such department on the day when the said appropriation account was closed, and to verify the balances appearing upon the annual appropriation account: Provided always, that the Comptroller and AuditorGeneral may, if he thinks fit, require the said department to transmit to him in lieu of such balance-sheet a certified statement showing the actual disposition of the balances appearing upon the annual appropriation account on the last day of the period of such account.

26. Every appropriation account when rendered to the Comptroller and Auditor-General shall be accompanied by an explanation showing how the balance or balances on the grant or grants included in the previous account have been adjusted, 
and shall also contain an explanatory statement of any excess of expenditure over the grant or grants included in such account, and such statement as well as the appropriation account shall be signed by such department.

27. Every appropriation account shall be examined by the Comptroller and Auditor-General on behalf of the House of Commons; and in the examination of such accounts the Comptroller and Auditor-General shall ascertain, first, whether the payments which the accounting department has charged to the grant are supported by vouchers or proofs of payments, and, second, whether the money expended has been applied to the purpose or purposes for which such grant was intended to provide: Provided always, and it is hereby enacted, that whenever the said Comptroller and Auditor-General shall be required by the Treasury to ascertain whether the expenditure included or to be included in an appropriation account, or any portion of such expenditure, is supported by the authority of the Treasury, the Comptroller and Auditor-General shall examine such expenditure with that object, and shall report to the Treasury any expenditure which may appear, upon such examination, to have been incurred without such authority; and if the Treasury should not thereupon see fit to sanction such unauthorised expenditure, it shall be regarded as being not properly chargeable to a Parliamentary grant, and shall be reported to the House of Commons in the manner hereinafter provided.

28. In order that such examination may, as far as possible, proceed pari passu with the cash transactions of the several accounting departments, the Comptroller and Auditor-General shall have free access, at all convenient times, to the books of account and other documents relating to the accounts of such departments, and may require the several departments concerned to furnish him from time to time, or at regular periods, with accounts of the cash transactions of such departments respectively up to such times or periods.

29. In conducting the examination of the vouchers relating 296 


\section{APPENDIX I}

to the appropriation of the grants for the several services enumerated in Schedule (B) to this Act annexed, the Comptroller and Auditor-General, after satisfying himself that the accounts bear evidence that the vouchers have been completely checked, examined, and certified as correct in every respect, and that they have been allowed and passed by the proper departmental officers, may admit the same as satisfactory evidence of payment in support of the charges to which they may relate: Provided always, that if the Treasury should desire any such vouchers to be examined by the Comptroller and Auditor-General in greater detail, the Comptroller and Auditor-General shall cause such vouchers to be subjected to such a detailed examination as the Treasury may think fit to prescribe.

3o. In conducting the examination of the vouchers relating to the appropriation of the grants for any services not enumerated in the aforesaid schedule, the Comptroller and AuditorGeneral shall test the accuracy of the castings and computation of the several items of such vouchers: Provided always, that when any vouchers have been certified to be correct by any officers specially authorised to examine the same, it shall be lawful for the Comptroller and AuditorGeneral, with the consent of the Treasury, to dispense with a second examination of the particular items of such vouchers.

3 . If during the progress of the examination by the Comptroller and Auditor-General herein-before directed any objections should arise to any item to be introduced into the appropriation account of any grant, such objections shall, notwithstanding such account shall not have been rendered to him, be immediately communicated by him to the department concerned, and if the objections should not be answered to his satisfaction by such department, they shall be referred by him to the Treasury, and the Treasury shall determine in what manner the items in question shall be entered in the annual appropriation account. 
32. In reporting as herein-before directed, for the information of the House of Commons, the result of the examination of the appropriation accounts, the Comptroller and AuditorGeneral shall prepare reports on the appropriation account of the Army and on that of the Navy separately.

He shall prepare a report on the appropriation accounts of the Departments of Customs, Inland Revenue, and Post Office.

He shall prepare a report or reports on the accounts relating to the several grants included within each of the classes into which the grants for civil services are divided in the Appropriation Act.

In all reports as aforesaid he shall call attention to every case in which it may appear to him that a grant has been exceeded, or that money received by a department from other sources than the grants for the year to which the account relates has not been applied or accounted for according to the directions of Parliament, or that a sum charged against a grant is not supported by proof of payment, or that a payment so charged did not occur within the period of the account, or was for any other reason not properly chargeable against the grant.

If the Treasury shall not, within the time prescribed by this Act, present to the House of Commons any report made by the Comptroller and Auditor-General on any of the appropriation accounts, or on the accounts of issues for Consolidated Fund services, the Comptroller and Auditor-General shall forthwith present such report.

\section{Accounts other than Appropriation Accounts}

33. Besides the appropriation accounts of the grants of Parliament, the Comptroller and Auditor-General shall examine and audit, if required so to do by the Treasury, and in accordance with any regulations that may be prescribed for his guidance in that behalf by the Treasury, the following accounts: viz., the accounts of all principal accountants, the 


\section{APPENDIX I}

accounts of the receip', of revenue by the Departments of Customs, Inland Revenue, and Post Office, the accounts of every receiver of money which is by law payable into Her Majesty's Exchequer, and any other public accounts which, though not relating directly to the receipt or expenditure of imperial funds, the Treasury may by minute to be laid before Parliament direct.

34. The accounts which by the last preceding section the Treasury are empowered to subject to the examination of the Comptroller and Auditor-General shall be rendered to him by the departments or officers who may be directed so to do by the Treasury; and the term "accountant," when used in this and the following sections of this Act with reference to any such accounts, shall be taken to mean the department or officer that may be so required by the Treasury to render the same; and every public officer into whose hands public moneys, either in the nature of revenue or fees of office, shall be paid by persons bound by law or regulation to do so, or by subordinate or other officers whose duty it may be to pay such moneys wholly or in part into the receipt of Her Majesty's Exchequer, or to apply the same to any public service, shall, at such times and in such form as the Treasury shall determine, render an account of his receipts and payments to the Comptroller and Auditor-General; and it shall be the duty of the Treasury to inform him of the appointment of every such officer.

35. Accountants shall transmit their accounts together with the authorities and vouchers relating thereto to the office of the Comptroller and Auditor-General in such form, and for such periods, and under such regulations as he may from time to time prescribe for the guidance of such accountants: Provided always, that no such regulations shall be obligatory on such accountants until they shall have been approved by the Treasury.

36. The Comptroller and Auditor-General shall examine the several accounts transmitted to him with as little delay 


\section{APPENDIX I}

as possible, and when the examination of each account shall be completed he shall make up a statement thereof in such form as he may deem fit, and if it shall appear from the statement so made up of any account, being an account current, that the balance thereon agrees with the accountant's balance, or if it shall appear from any account rendered by an accountant, as well as from the statement of such account by the Comptroller and Auditor-General, that the accountant is "even and quit," the Comptroller and Auditor-General is hereby required to sign and pass such statement of account so made up by him as aforesaid: Provided always, that in all other cases whatever the Comptroller and Auditor-General, having made up the statement of account as herein-before directed, shall transmit the same to the Treasury, who, having considered such statement, shall return it to him, with their warrant attached thereto, directing him to sign and pass the account, either conformably to the statement thereof, or with such alterations as the Treasury may deem just and reasonable; and a statement of the account made up by the Comptroller and Auditor-General in accordance with such Treasury warrant shall then be signed and passed by him: Provided further, that a list of all accounts which the Comptroller and Auditor-General may sign and pass (such list to be so prepared as to show thereon the charge, discharge, and balance of each account respectively) shall be submitted by him to the Treasury twice in every year, videlicet, not later than the first week of February and the first week of August.

37. It shall be lawful for the Comptroller and AuditorGeneral, in the examination of any accounts, to admit and allow, in cases where it shall appear to him to be reasonable and expedient for the public service, vouchers for any moneys expressed therein, although such vouchers be not stamped according to law.

38. As soon as any account shall have been signed and passed by the Comptroller and Auditor-General, he shall transmit to the accountant a certificate, in which the total 


\section{APPENDIX I}

amount of the sums forming respectively the charge and discharge of such account, and the balance, if any, remaining due to or by such accountant shall be set forth; and every such certificate shall be signed by him, and shall be valid and effectual to discharge the accountant as the case may be, either wholly or from so much of the amount with which he may have been chargeable as he may appear by such certificate to be discharged from: Provided always, that when any account, not being an account current, has been signed and passed by the Comptroller and Auditor-General with a balance due thereon to the Crown, he shall not make out or grant any such certificate as aforesaid until the accountant has satisfied him either that he has discharged the full amount of such balance, and any interest that may as herein-after provided be payable thereon, or that he has been relieved from the payment thereof, or of so much thereof as has not been paid, by a warrant from the Treasury.

39. No declaration shall be made by the Comptroller and Auditor-General before the Chancellor of the Exchequer in relation to any account or any state or statement thereof; nor shall any such state or statement be enrolled as of record in the office of Her Majesty's Remembrancer of the Court of Exchequer, any law, usage, or custom to the contrary notwithstanding; but every statement of an account made out, signed, and passed as aforesaid, shall be recorded in the office of the Comptroller and Auditor-General, and the recording of such statement of account in his office shall be as valid and effectual for enabling any process in the law against the party chargeable, and any other proceeding for the recovery of any balances and any interest thereon, and for all other purposes, as the enrolment of a declared account in the office of Her Majesty's Remembrancer would have been if this Act had not been passed; and a copy, certified under the hands of the Comptroller and Auditor-General, of the record of any such statement of account, shall be taken notice of and proceeded upon in the like manner as the record of any such 


\section{APPENDIX I}

declared account, enrolled as aforesaid, might have been if this Act had not been passed.

40. In all cases where the Comptroller and Auditor-General shall be required by the Treasury to examine and audit the accounts of the receipt, expenditure, sale, transfer, or delivery of any securities, stamps, Government stock or annuities, provisions, or stores, the property of Her Majesty, he shall, on the examination of such accounts being completed, transmit a statement thereof, or a report thereon, to the Treasury, who shall, if they think fit, signify their approval of such accounts to him, and he shall thereupon transmit to the accountant a certificate in a form to be from time to time determined by the Comptroller and Auditor-General, which shall be to such accountant a valid and effectual discharge from so much as he may thereby appear to be discharged from.

41. Every accountant shall, on the termination of his charge as such accountant, or in case of a deceased accountant his representatives, shall forthwith pay over any balance of public money then due to the public in respect of such charge to the public officer authorised to receive the same; and in all cases in which it shall appear to the Comptroller and Auditor-General that balances of public money have been improperly and unnecessarily retained by an accountant, he shall report the circumstances of such cases to the Treasury; and the Treasury shall take such measures as to them may seem expedient for recovering by legal process, or by other lawful ways and means, the amount of such balance or balances, together with interest thereon, upon the whole or part of such balance or balances, for such period of time and at such rate, not exceeding five pounds per centum per annum, as to the Treasury may appear just and reasonable.

42. In all cases where any estate belonging to a public accountant shall be sold under any writ of extent or any decree or order of the Courts of Chancery or Exchequer, and the purchaser thereof or of any part thereof shall have paid his purchase money into the hands of any public accountant 


\section{APPENDIX I}

authorised to receive the same, such purchaser shall be wholly exonerated and discharged from all further claims of Her Majesty for or in respect of any debt arising upon the account of such accountant, although the purchase money so paid be not sufficient in amount to discharge the whole of the said debt.

43. In all cases in which an accountant may be dissatisfied with any disallowance or charge in his accounts made by the Comptroller and Auditor-General such accountant shall have a right of appeal to the Treasury, who, after such further investigation as they may consider equitable, whether by viva voce examination or otherwise, may make such order directing the relief of the appellant wholly or in part from the disallowance or charge in question, as shall appear to them to be just and reasonable, and the Comptroller and AuditorGeneral shall govern himself accordingly.

44. It shall be lawful for the Treasury, from time to time, if they see fit so to do, to dispense with the transmission, to the Comptroller and Auditor-General, of any accounts not being accounts of the receipt and expenditure of public money, and with the audit of such accounts by him, any law, usage, or custom to the contrary notwithstanding: Provided always, that copies of any Treasury Minutes dispensing with the audit of such accounts shall be laid before Parliament.

45. Nothing in this Act contained shall extend to abridge or alter the rights and powers of Her Majesty to control, suspend, or prevent the execution of any process or proceeding, under this Act or otherwise, for recovering money due to the Crown.

46. The Acts mentioned in Schedule (C) to this Act annexed shall be repealed to the extent mentioned in such Schedule, and all accounts required or directed to be audited by the board of audit shall be audited according to the provisions of this Act; but nothing herein shall be deemed to confer upon the Treasury the powers with respect to audit vested in the Admiralty by the Greenwich Hospital Act, I865, or to affect any right, title, obligation, or liability acquired 


\section{APPENDIX I}

or accrued before the commencement of this Act: Provided always, that this Act shall not affect any proceeding which may have been commenced under any of the said Acts before this Act comes into operation.

47. This Act shall commence on the first day of April one thousand eight hundred and sixty-seven.

\section{SCHEDULE A}

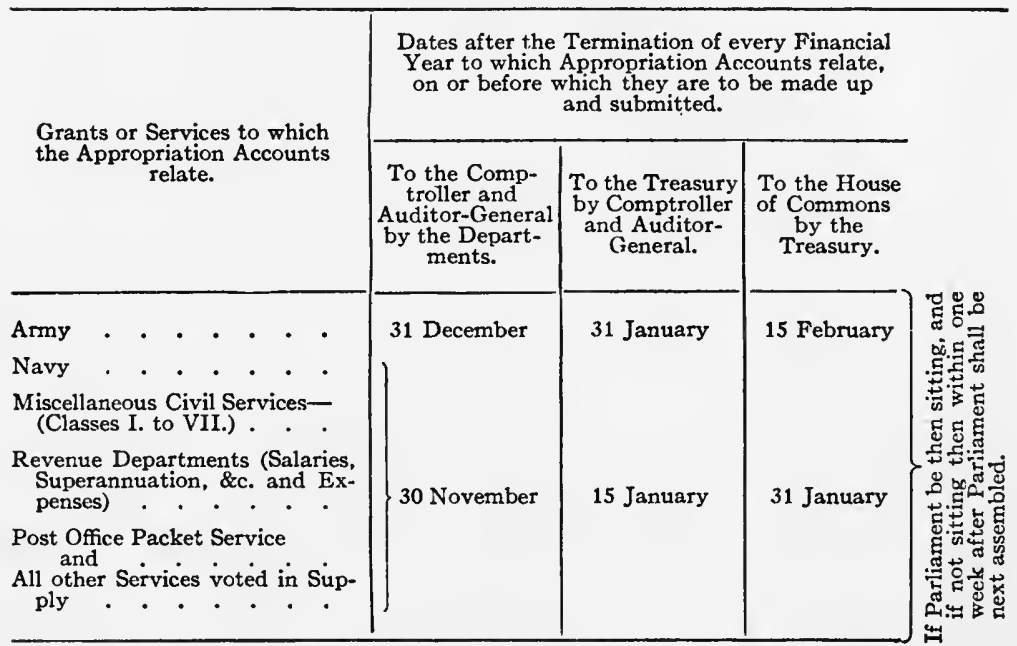

\section{SCHEDULE B}

\section{Army;}

Navy;

and such other services as the Treasury, by their minute to be laid before Parliament may direct; but no such minute shall take effect until it shall have lain before the House of Commons thirty days, unless it shall have been previously approved by a resolution of the House of Commons. 


\section{APPENDIX I}

\section{SCHEDULE C}

\section{Enactments Repealed}

\begin{tabular}{l|l}
\hline 25 Geo. 3. c. 52. An Act for better examining and auditing the Publick \\
\hline
\end{tabular} Accounts of this Kingdom.

$27 \mathrm{Geo}$ 3. c. 13. An Act for repealing the several in part. Duties of Customs and Excise, and granting other Duties in lieu thereof, and for applying the said Duties, together with the other Duties composing the Publick Revenue; for permitting the Importation of certain Goods, Wares, in part; namely, and Merchandize, the Produce or Manufacture of the European Dominions of the French King, into this Kingdom; and for applying certain unclaimed Monies, remaining in the Exchequer for the Payment of Annuities on Lives, to the Reduction of the National Debt

Section seventy-two.

$39 \& 40$ Geo. 3. c. 54 . in part.

45 Geo. 3. c. 55.

$46 \mathrm{Geo} .3$. c. 141.

$47 \mathrm{Geo} .3$. Sess. 2. c. 39.

52 Geo. 3. c. 52.
An Act for more effectually charging Publick Accountants with the Payment of Interest; for allowing Interest to them in certain in part; namely,Cases; and for compelling the Payment of Balances due from them

Sections four, five, six, nine, ten, and thirteen.

An Act to amend an Act made in the Twenty-fifth Year of His present Majesty, for better examining and auditing the Publick Accounts of this Kingdom; and for enabling the Commissioners, in certain Cases, to allow of Vouchers, although not stamped according to Law.

An Act for making more effectual Provision for the more speedy and regular Examination and Audit of the Public Accounts of this Kingdom.

An Act for more effectually charging Publick Accountants with Interest upon Balances, and for other Purposes relating to the passing of Publick Accounts. An Act to provide for the speedy and regular Examination and Audit of the Public Accounts of Ireland; and to repeal certain former Acts relating thereto. 


\section{APPENDIX I}

$53 \mathrm{Geo} 3$. c. 150.

57 Geo. 3. c. 48.

$1 \& 2$ Geo. 4 . c. 121. in part.

10 Geo. 4. c. 27.

$2 \& 3$ Will. 4. c. 26.

$2 \& 3$ Will. 4. c. 99 .

c. 104.

$4 \& 5$ Will. 4. c. 15. in part.
An Act for the more speedy and effectual Examination and Audit of the Accounts of Military Expenditure in Spain and Portugal; for removing Delays in passing the Public Accounts; and for making new Arrangements for conducting the Business of the Audit Office.

An Act to make further Provision for the Adjustment of the Accounts of the Consolidated Fund of the United Kingdom; and for making good any occasional Deficiency which may arise in the said Fund in Great Britain or Ireland respectively; and to direct the Application of Monies by the Commissioners for the Reduction of the National Debt.

An Act to alter and abolish certain Forms of Proceedings in the Exchequer and Audit Office relative to Public Accountants; and for making further Provisions for the Purpose of facilitating and expediting the passing of Public Ac- $\}$ :counts in Great Britain; and to render perpetual and amend an Act passed in the Fifty-fourth Year of His late Majesty for the effectual Examination of the Accounts of certain Colonial Revenues

Except sections twenty-seven, twenty-eight, and twenty-nine.

An Act to amend the several Acts for regulating the Reduction of the National Debt.

An Act to authorize the Commissioners for Auditing the Public Accounts of Great Britain to examine and audit Accounts of the Receipt and Expenditure of Colonial Revenues.

An Act for transferring the Powers and Duties of the Commissioners of Public Accounts in Ireland to the Commissioners for Auditing the Public Accounts of Great Britain.

An Act to regulate the Period of rendering the Public Accounts and making up the General Imprest Certificates.

An Act to regulate the Office of $\left.\begin{array}{l}\text { the Receipt of His Majesty's } \\ \text { Exchequer at Westminster }\end{array}\right\}$

Except sections seven and twenty-six. 


\section{APPENDIX I}

3 \& 4 Vict.

c. 108.

in part.

$9 \& 10$ Vict.

c. 92 .

$14 \& 15$ Vict.

c. 42 .

in part.

17 \& 18 Vict.

c. 19.

c. 94 . in part.

18 \& 19 Vict.

c. 96. in part.

$24 \& 25$ Vict.

c. 93.

$28 \& 29$ Vict.

c. 93.
An Act for the Regulation of Municipal Corporations in Ire- $\}$ in part; namely,-

Sections two hundred and thirteen and two hundred and fourteen.

An Act to provide for the Preparation, Audit, and Presentation to Parliament of Annual Accounts of the Receipt and Expenditure of the Naval and Military Departments.

An Act to make better Provision for the Management of the Woods, Forests, and Land Revenues of in pari; namely,the Crown, and for the Direction of Public Works and Buildings

Section thirty-eight wholly, and section thirty-nine as far as it relates to the Accounts of the Commissioners of Her Majesty's Works and Public Buildings.

The Naval Pay and Prize Act, 1854

An Act to alter the mode of providing for certain Expenses now charged upon certain Branches in part; namely,of the Public Revenues and upon the Consolidated Fund

Sections three, four, and five.

The Supplemental Customs Con- $\}$ in part; namely,-
solidation Act, 1855 Section one.

An Act to provide for the Preparation, Audit, and Presentation to Parliament of Annual Accounts of the Appropriation of the Moneys voted for the Revenue Departments.

An Act to consolidate the Offices of Comptroller-General of the Exchequer and Chairman of the Commissioners for auditing the Public Accounts, and for other Purposes.

\section{TREASURY MINUTE DATED 2ND MARCH 1867}

I. My Lords have had under consideration the Act 29 \& 30 Vict. c. 39, intituled "An Act to consolidate the Duties of the Exchequer and Audit Departments, to regulate the Receipt, Custody and Issue of Public Moneys, and to provide for the Audit of the Accounts thereof." 


\section{APPENDIX I}

2. The regulations necessary for carrying into effect the provisions of this Act may be divided under three heads:-

Ist. The Regulations connected with the accounts of the "Appropriation" of the Grants of Parliament.

2nd. The Regulations applicable to the Audit of the Accounts of persons intrusted with the receipt and disbursement of Public or other Moneys.

3rd. The Regulations for carrying into effect the provisions of the Act so far as they relate to the receipt and issue of Public Moneys on the Exchequer Account.

3. The provisions relating to the Audit of the "Appropriation" Accounts referred to under the first head are contained in the sections 21 to 32 of the Act. My Lords have already, as appears by Their Minute of June 22nd, I866, taken steps to enable them to discharge the duties imposed upon them by the 23 rd section of the Act, by appointing a Committee to prepare plans and regulations for keeping and rendering for audit the several Departmental Accounts. They have instructed the Committee to consider also what improvements may be made in the classification of the Annual Estimates for Miscellaneous Services, the accounts for which (with the exception of those of the Departments of Works and Public Buildings, and of Woods) are now, for the first time, to be subjected to an "Appropriation" Audit. When the Committee shall have made their Reports upon these matters My Lords will be prepared to make such regulations as may appear to them advisable, in order to carry out the intentions of the Act in this respect; and they direct that, until such Reports shall have been received, and instructions consequent thereupon shall have been issued in reference to the preparing and rendering of any of the Appropriation Accounts, every account which is now audited by the Commissioners of Audit, and which relates to the final expenditure of a vote, shall continue to be examined in the same manner, and under the same regulations as they would have been, if the Com- 


\section{APPENDIX I}

missioners of Audit had continued to be charged with the Audit thereof.

4. With respect to the Audit of Accounts, other than Appropriation Accounts, referred to under the second head, My Lords direct that the Accounts specially designated in the 33 rd section of the Act, annexed to this Minute shall be audited by the Exchequer and Audit Department in the same manner and under the same regulations (so far as the same are not affected by the Act) as they would have been if the Commissioners of Audit had continued to be charged with the Audit thereof.

My Lords will be prepared, by a subsequent Minute, to direct what other Public Accounts, not relating directly to the Receipt or Expenditure of Imperial Funds, shall be transmitted to the Comptroller and Auditor-General for examination and audit under the provisions of the said 33rd section.

5. My Lords proceed to define the regulations for the Receipt and Issue of Public Money on the Exchequer Account, referred to under the third head.

6. The Ioth section of the above Act relates to the payment of the gross receipts of the Revenue Departments to the Account of Her Majesty's Exchequer at the Bank of England, and to a similar Account at the Bank of Ireland. My Lords desire that the Commissioners of Customs, and the Commissioners of Inland Revenue, will continue to cause the Revenue, collected in their respective Departments, to be paid to the Banks daily, as prescribed by Treasury Minute of the 2nd March $1855 ;^{1}$ and the Postmaster-General and the Commissioners of Woods and Forests, and the Paymaster-General will also continue to regulate the payments of Revenue, and other receipts in their respective Departments to the Exchequer Account, from time to time, according to the present custom. The several Revenue Departments will transmit to this Board as well as to the Comptroller and AuditorGeneral certificates, according to the forms annexed, No. I

${ }^{1}$ See Parliamentary Paper No. 375, Session 1856, Appendix, page 583. 
( $\mathrm{a} \& \mathrm{~b}$ ), of the sums so paid to the Exchequer Account, at the same time as their orders are sent to the Banks to place the moneys to the credit of the said Account.

7. The I2th section of the Act directs that accounts of the income and ${ }^{1}$ charge of the Consolidated Fund shall be prepared by the Treasury at the close of each quarter, and that such accounts shall be forthwith transmitted to the Comptroller and Auditor-General. The object of this enactment is to enable that officer to certify the amount of the deficiency for which this Board may be authorised to obtain advances, from the Banks of England and Ireland, to meet the charges of the Consolidated Fund for each quarter; and also to enable him to satisfy himself of the correctness of the amount for which credits on the Exchequer Account, to meet such charges, may from time to time be authorised by this Board under the $13^{\text {th }}$ section of the Act. My Lords will cause the said accounts to be transmitted to the Comptroller and Auditor-General as soon as possible after the close of each quarter, prepared in the Form No. 2, annexed to this Minute; and the Comptroller and Auditor-General, after satisfying himself of the correctness of the deficiency of the income to meet the charge of the Consolidated Fund for the said quarter, will transmit to the said Banks a certificate of the amount, of such deficiency according to the Form No. 3, annexed.

8. The applications of the Treasury to the Banks for advances from time to time on account of the said deficiency will be according to the Form No. 4, annexed.

9. The $\mathrm{I} 3^{\text {th }}$ section of the Act requires the Comptroller and Auditor-General to grant to this Board, on their requisitions authorising the same, credits on the Exchequer Account at the Banks of England and Ireland to provide for the payment of the charges on the Consolidated Fund included in the aforesaid quarterly accounts of Income and Charge remaining

${ }^{1}$ The words "incoming charge" are a palpable slip and have been corrected. 
unpaid; as well as to grant credits from time to time during the succeeding quarter, on similar requisitions for services payable out of the "growing produce" of the Consolidated Fund.

I0. At the periods when the quarterly charges on the Consolidated Fund become payable, My Lords will authorise the Comptroller and Auditor-General, by requisitions according to Forms Nos. 5 and 6, to grant such credits, in part or in full of such charges. When the credits so authorised shall have been granted to this Board by the Comptroller and AuditorGeneral according to Forms Nos. 7 and 8, My Lords will direct the Banks, from time to time, to make the necessary issues or transfers, as required by the Act, from the Exchequer Account to the accounts of the Principal Accountants, charged with the duty of making the public payments, according to Form No. 9, annexed to this Minute. These authorities, when acted upon, are to be transmitted by the Banks to the Comptroller and Auditor-General.

I I. A daily account of such issues (including the issues out of credits granted for supply services hereinafter referred to) is to be transmitted by the Bank of England to the Comptroller and Auditor-General and to this Board, according to Form No. IO; and a similar account is to be sent by the Bank of Ireland to the two departments according to Form No. I I, annexed to this Minute.

I2. The issues to Principal Accountants will be regulated according to the provisions of the I5th section of the Act. When Ways and Means shall have been granted to Her Majesty by Act, My Lords will authorise the Comptroller and Auditor-General by requisition according to Form No. I2, annexed, to place credits at their disposal at the Banks of England and Ireland to enable them to supply the Principal Accountants with the funds necessary for carrying on the public service. Upon the grant of credits on the Exchequer Accounts at the said Banks by the Comptroller and AuditorGeneral (according to Form No. 13), the actual issues or 
transfers to the accounts of such Accountants will be made by orders of this Board, under the authority of a Royal Order (see Form No. I4, annexed), in accordance with the provisions of the I4th and I 5 th sections of the Act.

I3. The orders for issues for Supply Services will be prepared according to Form No. I5, annexed to this minute, and when acted upon they will be transmitted by the Bank of England and the Bank of Ireland to the Comptroller and Auditor-General to afford him the means of verifying the accounts to be prepared by this Board, under the 16th section of the Act, and which he is required by the Act to certify previously to their being submitted to Parliament. A daily statement of such issues will be included in the accounts to be transmitted to this Board, and to the Comptroller and Auditor-General, by the Banks of England and Ireland (as hereinbefore directed), according to Forms Nos. IO and I I.

I4. On the first application of the new regulations after the close of the present financial year, it will be necessary that a Royal Order should be obtained for cancelling all previous Royal Orders for public Supply Services, so far as they may remain unexecuted on the 3 Ist March next. A new Royal Order will therefore be obtained to authorise the issues to Principal Accountants out of credits to be granted upon the Exchequer Account to the extent of the balance of Ways and Means of prior years which may remain unissued on that day.

I5. As under the existing system of granting credits upon the Account of Her Majesty's Exchequer at the Bank of England to Public Accountants, there will remain unexhausted credits on that Account on the 3 Ist March next, and as after the Ist April next, actual transfers to those Accounts are to be substituted for credits on the Exchequer Account, $\mathrm{My}$ Lords request that the Bank of England will, on 31st March next, transfer all such balances of credits from the Exchequer Account to the separate Accounts of the persons in whose favour they may have been granted.

16. It will be necessary, in the case of the Paymaster- 


\section{APPENDIX I}

General, to open in the books of the Bank of England a new account, to be called "The Paymaster-General's Supply Account," to which the balance of credits above mentioned granted to that officer should be transferred. This Account is to be operated upon by the Paymaster-General solely by Writes-off to his Drawing and Bill Accounts.

17. The I6th section of the Act, so far as its provisions relate to the preparation of the Account therein referred to, showing the surplus of Revenue applicable to the reduction of the National Debt, is already in operation under the provisions of the Act $57 \mathrm{Geo}$. III. c. 48 ; but a new provision has been added to the section, which renders it necessary that the Account in question should be certified by the Comptroller and Auditor-General, before it is presented to Parliament. My Lords will cause the Account to be transmitted to the Comptroller and Auditor-General immediately after the expiration of each quarter, in order that it may be certified and presented to the House of Commons within the period of fifteen days specified in the Act.

I8. Let a copy of this Minute be transmitted to Sir William Dunbar, ${ }^{1}$ to the Paymaster-General, the several Revenue Departments, the Bank of England, the National Debt Commissioners, the Bank of Ireland, the Inclosure Commissioners, the Master of the Mint, and the Commissioners of Public Works in Ireland, for their information and guidance; and request Sir William Dunbar to inform this Board if he has any alteration to suggest in the Forms of Authorities, Nos. 3, 7,8 , and 13 , annexed to this Minute, which are to emanate from his department.

19. Let a copy of this Minute be laid before the House of Commons.

${ }^{1}$ Then Comptroller and Auditor General. 


\section{APPENDIX II \\ CONSOLIDATED FUND (NO. I) BILL, I9I 2}

A BiLl to apply certain sums out of the Consolidated Fund to the service of the years ending on the thirty-first day of March one thousand nine hundred and eleven, one thousand nine hundred and twelve, and one thousand nine hundred and thirteen.

Most Gracious Sovereign-We, Your Majesty's most dutiful and loyal subjects, the Commons of the United Kingdom of Great Britain and Ireland in Parliament assembled, towards making good the supply which we have cheerfully granted to Your Majesty in this session of Parliament, have resolved to grant unto Your Majesty the sums herein-after mentioned; and do therefore most humbly beseech Your Majesty that it may be enacted, and be it enacted by the King's most Excellent Majesty, by and with the advice and consent of the Lords Spiritual and Temporal, and Commons, in this present Parliament assembled, and by the authority of the same, as follows:-

I. The Treasury may issue out of the Consolidated Fund of the United Kingdom of Great Britain and Ireland, and apply towards making good the supply granted to His Majesty for the service of the years ending on the thirty-first day of March one thousand nine hundred and eleven and one thousand nine hundred and twelve, the sum of two hundred and forty-one thousand one hundred and seventeen pounds.

2. The Treasury may issue out of the Consolidated Fund of the United Kingdom of Great Britain and Ireland, and apply towards making good the supply granted to His Majesty 
for the service of the year ending on the thirty-first day of March one thousand nine hundred and thirteen the sum of fifty-nine million seventy-two thousand one hundred pounds.

3.-(I) The Treasury may borrow from any person, by the issue of Treasury Bills or otherwise, and the Bank of England and the Bank of Ireland may advance to the Treasury on the credit of the said sums, any sum or sums not exceeding in the whole fifty-nine million three hundred and thirteen thousand two hundred and seventeen pounds.

(2) The date of payment of any Treasury Bills issued under this section shall be a date not later than the thirtyfirst day of March one thousand nine hundred and thirteen, and section six of the Treasury Bills Act, 1877 (which relates to the renewal of bills), shall not apply with respect to those bills.

- (3) Any money borrowed otherwise than on Treasury Bills shall be repaid, with interest not exceeding five pounds per cent per annum, out of the growing produce of the Consolidated Fund, at any period not later than the next succeeding quarter to that in which the money was borrowed.

(4) Any money borrowed under this section shall be placed to the credit of the account of the Exchequer, and shall form part of the said Consolidated Fund, and be available in any manner in which such Fund is available.

4. This Act may be cited as the Consolidated Fund (No. I) Act, I9I2.

Note.-Section 6 of the Treasury Bills Act, 1877, referred to in Clause 3 (2) of the above Bill, empowers the Treasury to issue Treasury Bills or Exchequer Bills in lieu of Bills paid off during the same financial year. 


\section{APPENDIX III}

CONSOLIDATED FUND (APPROPRIATION) ACT, I9I2

2 \& 3 Geo. V. c. 7 [7th August 1912]

An Act to apply a sum out of the Consolidated Fund to the service of the year ending on the thirty-first day of March one thousand nine hundred and thirteen, and to appropriate the Supplies granted in this Session of Parliament.

Most Gracious Sovereign-We, Your Majesty's most dutiful and loyal subjects, the Commons of the United Kingdom of Great Britain and Ireland in Parliament assembled, towards making good the supply which we have cheerfully granted to Your Majesty in this session of Parliament, have resolved to grant unto Your Majesty the sum herein-after mentioned; and do therefore most humbly beseech Your Majesty that it may be enacted; and be it enacted by the King's most Excellent Majesty, by and with the advice and consent of the Lords Spiritual and Temporal, and Commons, in this present Parliament assembled, and by the authority of the same, as follows:-

\section{Grants out of Consolidated Fund}

I. The Treasury may issue out of the Consolidated Fund of the United Kingdom of Great Britain and Ireland, and apply towards making good the supply granted to His Majesty for the service of the year ending on the thirty-first day of March one thousand nine hundred and thirteen the sum of ninety-two million eight hundred and forty-seven thousand three hundred and forty-three pounds. 
2.-(I) The Treasury may borrow from any person, by the issue of Treasury Bills or otherwise, and the Bank of England and the Bank of Ireland may advance to the Treasury on the credit of the said sums, any sum or sums not exceeding in the whole ninety-two million eight hundred and forty-seven thousand three hundred and forty-three pounds.

(2) The date of payment of any Treasury Bills issued under this section shall be a date not later than the thirtyfirst day of March one thousand nine hundred and thirteen and section six of the Treasury Bills Act, 1877 (which relates to the renewal of bills), shall not apply with respect to those bills.

(3) Any money borrowed otherwise than on Treasury Bills shall be repaid, with interest not exceeding five pounds per cent per annum, out of the growing produce of the Consolidated Fund, at any period not later than the next succeeding quarter to that in which the money was borrowed.

(4) Any money borrowed under this section shall be placed to the credit of the account of the Exchequer, and shall form part of the said Consolidated Fund, and be available in any manner in which such Fund is available.

\section{Appropriation of Grants}

3. All sums granted by this Act and the other Act mentioned in Schedule (A.) annexed to this Act out of the said Consolidated Fund towards making good the supply granted to His Majesty, amounting, as appears by the said schedule, in the aggregate, to the sum of one hundred and fifty-two million one hundred and sixty thousand five hundred and sixty pounds are appropriated, and shall be deemed to have been appropriated as from the date of the passing of the Acts mentioned in the said Schedule (A.), for the services and purposes expressed in Schedule (B.) annexed hereto.

The abstract of schedules and schedules annexed hereto, with the notes (if any) to such schedules, shall be deemed to 
be part of this Act in the same manner as if they had been contained in the body thereof.

In addition to the sums hereby granted out of the Consolidated Fund, there may be applied out of any money directed under section two of the Public Accounts and Charges Act, I89r, to be applied as appropriations in aid of the grants for the services and purposes specified in Schedule (B.) annexed hereto, the sums respectively set forth in the last column of the said schedule.

4.- (I) So long as the aggregate expenditure on naval and military services respectively is not made to exceed the aggregate sums appropriated by this Act for those services respectively, any surplus arising on any vote for those services, either by an excess of the sum realised on account of appropriations in aid of the vote over the sum which may be applied under this Act as appropriations in aid of that vote, or by saving of expenditure on that vote, may, with the sanction of the Treasury, be temporarily applied either in making up any deficiency in the sums realised on account of appropriations in aid of any other vote in the same department, or in defraying expenditure in the same department which is not provided for in the sums appropriated to the service of the department by this Act, and which it may be detrimental to the public service to postpone until provision can be made for it by Parliament in the usual course.

(2) A statement showing all cases in which the sanction of the Treasury has been given to the temporary application of a surplus under this section, and showing the circumstances under which the sanction of the Treasury has been given, shall be laid before the House of Commons with the appropriation accounts of the naval and military services for the year, in order that any temporary application of any surplus sanctioned by the Treasury under this section may be submitted for the sanction of Parliament.

5. Whereas under the powers given for the purpose by the Appropriation Act, I9IO, and the Appropriation Act, I9II, 3 I 8 


\section{APPENDIX III}

surpluses arising on certain votes for the naval and military services respectively have been temporarily applied as shown in the accounts set out in Schedule (C.) to this Act:

It is enacted that the application of those surpluses as shown in the said accounts is hereby sanctioned.

6. A person shall not receive any part of a grant which may be made in pursuance of this Act for half-pay or army, navy, or civil non-effective services, until he has subscribed such declaration as may from time to time be prescribed by a warrant of the Treasury before one of the persons prescribed by such warrant:

Provided that, whenever any such payment is made at more frequent intervals than once in a quarter, the Treasury may dispense with the production of more than one declaration in respect of each quarter.

Any person who makes a declaration for the purpose of this section, knowing the same to be untrue in any material particular, shall be guilty of a misdemeanour.

7. This Act may be cited for all purposes as the Appropriation Act, I9r2. 
ABSTRACT OF SCHEDULES (A.) AND (B.) To WHICH THIS ACT REFERS SCHEDULE (A.)

Grants out of the Consolidated Fund . . . . $£ 152,160,560$ SCHEDULE (B.)-APPRopriation of Grants

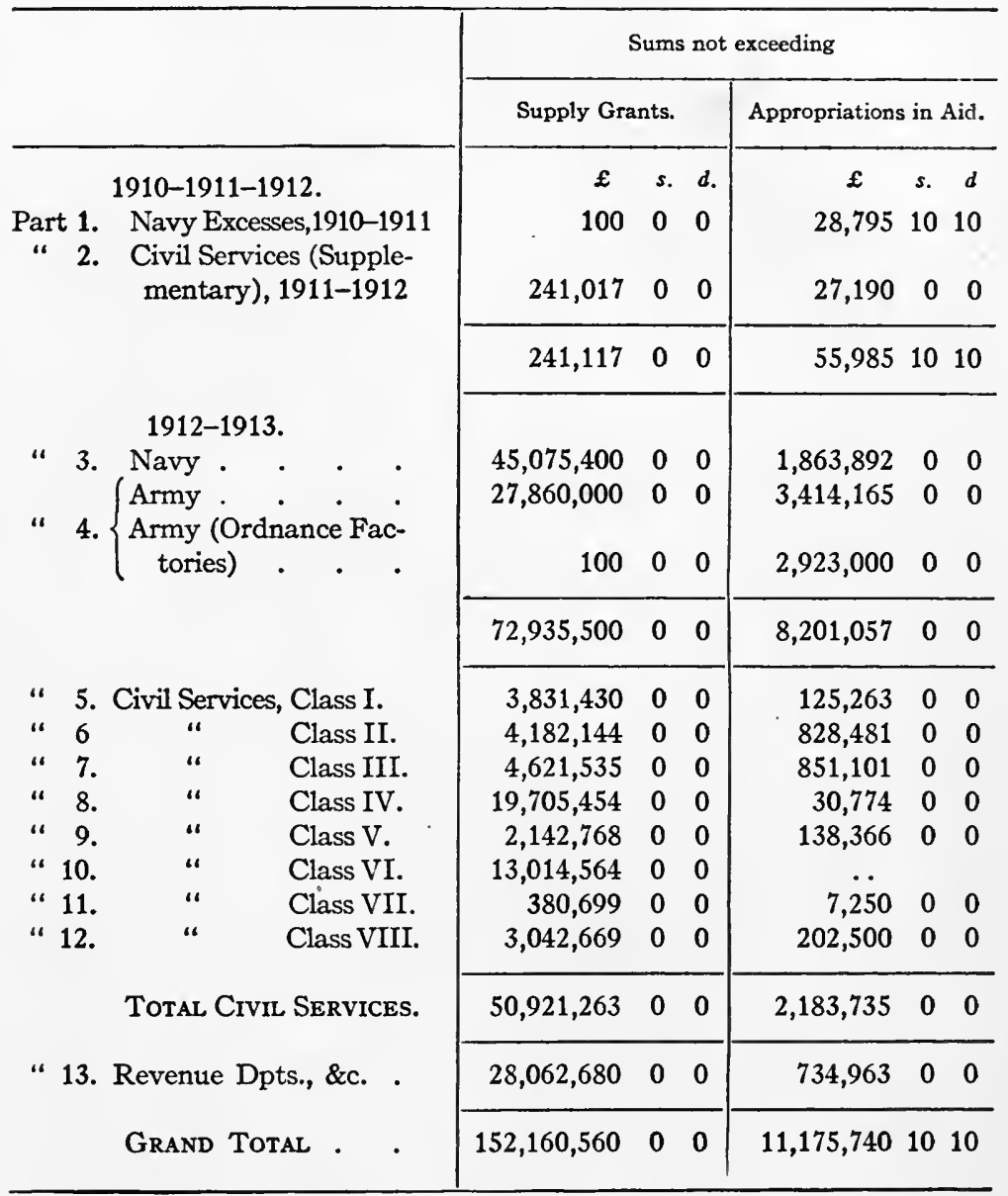




\section{SCHEDULE (A.)}

\section{Grants out of the Consolidated Fund}

For the service of the years ended on the s. d. 31st day of March 1911 and 1912:-

Under Act 2 Geo. 5. c. 1 . . . $\quad 241,117 \quad 0 \quad 0$

For the service of the year ending on the 31st day of March 1913:-

Under Act 2 Geo. 5. c. 1 . . . 59,072,100 00

Under this Act . . . . . . $\begin{array}{llll}92,847,343 & 0 & 0\end{array}$

Total . . . . . $152,160,560 \quad 0 \quad 0$

SCHEDULE (B.)-PART 1

Navy ExCesses, 1910-1911

Sum granted to make good Excesses of Navy Expenditure beyond the Grants for the year ended on the 31st day of March 1911
Sums not exceeding

\begin{tabular}{|c|c|c|}
\hline Supply & Grants. & $\begin{array}{l}\text { Appropriations } \\
\text { in Aid. }\end{array}$ \\
\hline $\mathfrak{E}$ & s. d. & $\begin{array}{lll} & \text { s. } & d .\end{array}$ \\
\hline 100 & 00 & 28,7951010 \\
\hline
\end{tabular}




\section{APPENDIX III}

\section{SCHEDULE (B.)-PART 2}

Crvil Services (Supplementary), 1911-1912

Schedule of Supplementary Sums granted to defray the charges for the Services herein particularly mentioned for the year ended on the 31st day of March 1912; viz.:-



\section{CIVIL SERVICES.}

\section{Class II.}

For the Salaries and Expenses in the Offices of the House of Commons

For the Salaries and Expenses of the Board of Agriculture and Fisheries, and of Royal Botanic Gardens, Kew, including certain Grants in Aid

For Stationery, Printing, Paper, Binding and Printed Books for the Public Service, for the Salaries and Expenses of the Stationery Office, and for Sundry Miscellaneous Services, including Reports of Parliamentary Debates

For the Salaries and Expenses of the Department of Agriculture and other Industries and Technical Instruction for Ireland, and of the Services administered by that Department

For the Salaries and Expenses of the Local Government Board, Ireland, and to enable it to make good certain Statutory advances

$$
\text { Class III. }
$$

For certain Miscellaneous Legal Expenses For such of the Salaries and Expenses of the Supreme Court of Judicature and Court of Criminal Appeal as are not charged on the Consolidated Fund

For the Salaries and Expenses of the Establishment of the Crofters Commission.
Sums not exceeding

\begin{tabular}{|c|c|}
\hline Supply Grants. & $\begin{array}{l}\text { Appropriations } \\
\text { in Aid. }\end{array}$ \\
\hline E & $£$ \\
\hline 10 & 940 \\
\hline 11,400 & 18,105 \\
\hline 47,000 & 2,000 \\
\hline 5 & 6,645 \\
\hline 50,000 & . \\
\hline 1,000 & .. \\
\hline 1,600 & . \\
\hline 120 & . \\
\hline 111,135 & 27,690 \\
\hline
\end{tabular}




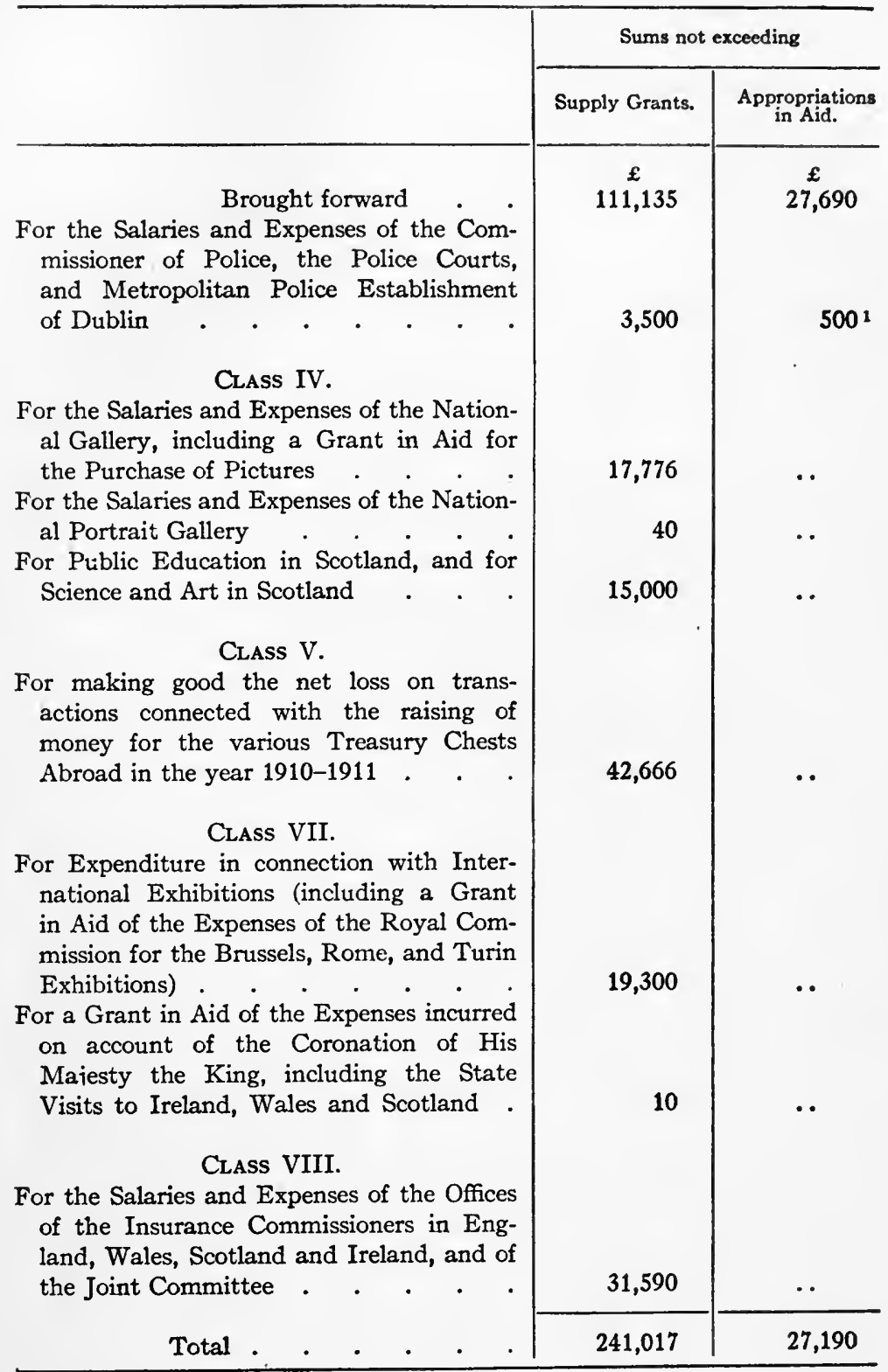

1 Deficit. 


\section{APPENDIX III}

\section{SCHEDULE (B.)-PART 3}

\section{NAVY}

SChedule of Sums granted, and of the sums which may be applied as appropriations in aid in addition thereto, to defray the charges of the NAVY SERvices herein particularly mentioned, which will come in course of payment during the year ending on the 31st day of March 1913; viz.:-

1. For wages, \&c., to 137,500 officers, seamen, and boys, coastguard, and royal marines (including an additional number of $\mathbf{1 5 0 0}$ men and boys and an additional sum of $60,000 l$.)

2. For victualling and clothing for the navy, including the cost of victualling establishments at home and abroad (including an additional sum of 54,000l.)

3. For medical services, including the cost of medical establishments at home and abroad

4. For martial law

5. For educational services. . . .

6. For scientific services . . . .

7. For the royal naval reserve, the royal fleet reserve (including seamen pensioner reserve), and the royal naval volunteers, \&c.

8. Sect. 1. For the personnel for shipbuilding, repairs, maintenance, \&c., including the cost of establishments of dockyards and naval yards at home and abroad (including an additional sum of $35,000 l$.)

" Sect. 2. For the matériel for shipbuilding, repairs, maintenance, \&c., including the cost of establishments of dockyards and naval yards at home and abroad

Carried forward

\begin{tabular}{|c|c|}
\hline \multicolumn{2}{|c|}{ Sums not exceeding } \\
\hline Supply Grants. & $\begin{array}{l}\text { Appropriations } \\
\text { in Aid. }\end{array}$ \\
\hline $\boldsymbol{E}$ & $£$ \\
\hline $7,687,000$ & 174,500 \\
\hline $2,682,100$ & 731,337 \\
\hline 269,900 & 20,065 \\
\hline 3,500 & 100 \\
\hline 152,500 & 66,385 \\
\hline 72,000 & 31,789 \\
\hline 426,700 & 9,732 \\
\hline $3,528,800$ & 22,000 \\
\hline $5,076,800$ & 380,300 \\
\hline $19,899,300$ & $1,436,208$ \\
\hline
\end{tabular}




\begin{tabular}{|c|c|c|}
\hline \multirow[b]{2}{*}{. } & \multicolumn{2}{|c|}{ Sums not exceeding } \\
\hline & Supply Grants. & $\begin{array}{l}\text { Appropriations } \\
\text { in Aid. }\end{array}$ \\
\hline $\begin{array}{l}\text { Bo. Brought forward } \\
\text { 8. Sect. 3. For contract work for ship- } \\
\text { building, repairs, \&c. (including an } \\
\text { additional sum of } 611,000 l . \text { ) } \\
\text { 9. For naval armaments (including an ad- } \\
\text { ditional sum of } 200,000 l \text {.) } \\
\text { 10. For works, buildings, and repairs at home } \\
\text { and abroad, including the cost of } \\
\text { superintendence, purchase of sites, } \\
\text { grants in aid, and other charges con- } \\
\text { nected therewith (including an addi- } \\
\text { tional sum of } 30,000 l \text {.) . } \\
\text { 11. For various miscellaneous effective serv- } \\
\text { ices . } \\
\text { 12. For the Admiralty Office . } \\
\text { 13. For half-pay, and retired pay to officers } \\
\text { of the navy and marines . } \\
\text { 14. For naval and marine pensions, gratui- } \\
\text { ties and compassionate allowances . } \\
\text { 15. For civil superannuation, compensation } \\
\text { allowances, and gratuities - }\end{array}$ & $\begin{array}{r}3,545,000 \\
532,000 \\
428,500 \\
955,800 \\
1,516,200 \\
413,000\end{array}$ & $\begin{array}{r}32,000 \\
13,386 \\
8,850 \\
21,412 \\
30,926 \\
410\end{array}$ \\
\hline Total Navy Services & $45,075,400$ & $1,863,892$ \\
\hline
\end{tabular}


SCHEDULE (B.)-PART 4

\section{ARMY}

SCHEdule of Sums granted, and of the sums which may be applied as appropriations in aid in addition thereto, to defray the charges of the ARMY SERVICES herein particularly mentioned, which will come in course of payment during the year ending on the 31st day of March 1913; viz:-

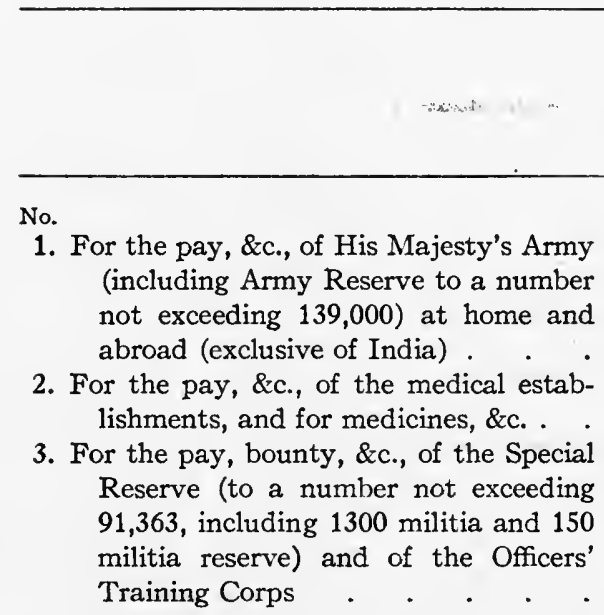

4. For grants, pay, allowances, training, and miscellaneous charges of the Territorial Force (not exceeding 319,673 men, including 5000 Territorial Force Reserve), and Channel Islands and Colonial Militia, including the expense of permanent staff .

5. For establishments for military education

6. For quartering, transport, and remounts

7. For supplies and clothing

8. For the Ordnance Department establishments and for general stores . .

9. For armaments, aviation and engineer stores, including technical committees

\begin{tabular}{|c|c|}
\hline \multicolumn{2}{|c|}{ Sums not exceeding } \\
\hline Supply Grants. & $\begin{array}{l}\text { Appropriations } \\
\text { in Aid. }\end{array}$ \\
\hline$£$ & $\mathfrak{E}$ \\
\hline $8,536,000$ & $1,354,000$ \\
\hline 436,000 & 1,700 \\
\hline 715,000 & 6,600 \\
\hline $2,780,000$ & 4,800 \\
\hline 142,000 & 89,100 \\
\hline $1,624,000$ & 67,000 \\
\hline $4,275,000$ & 198,500 \\
\hline 615,000 & 220,000 \\
\hline $1,718,000$ & 325,000 \\
\hline $20,841,000$ & $2,266,700$ \\
\hline
\end{tabular}


No.

Brought forward
10. For works, buildings, and repairs, lands, and miscellaneous engineer services, including staff in connection therewith

11. For miscellaneous effective services

12. For the War Office

13. For rewards; half-pay; retired pay; widows' pensions; and other noneffective charges for officers .

14. For Chelsea and Kilmainham hospitals; for out pensions; for rewards for distinguished services; for widows' pensions; and for other non-effective charges for warrant officers, noncommissioned officers, and men, \&c. .

17. For civil superannuation, compensation, and additional allowances, gratuities, injury grants, \&c. . . . .

\section{Total Army Services . .}

Army (Ordnance Factories).

For the ordnance factories, the cost of productions of which is charged to the army, navy, and Indian and Colonial Governments, \&c.

Total Army Services (INCluding ORD-) NANCE FACTORIES)

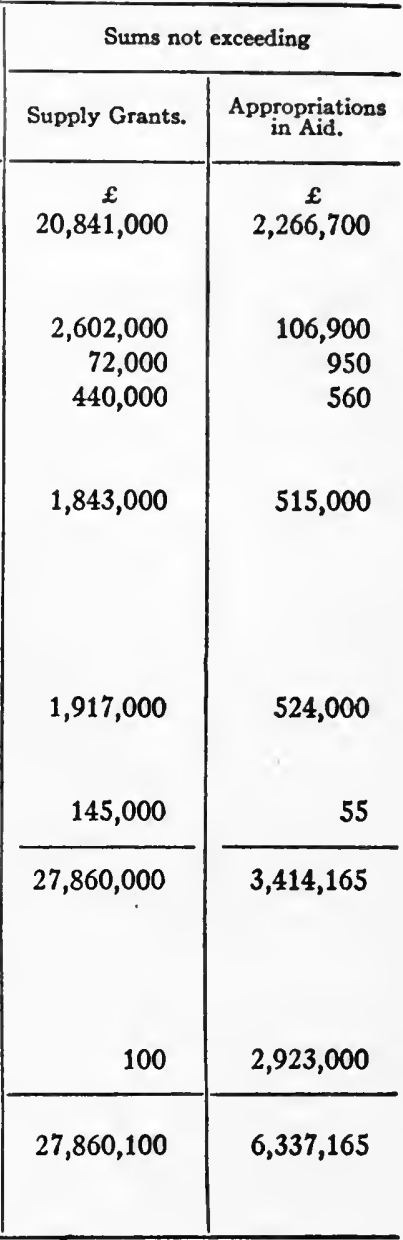




\section{SCHEDULE (B.)-PART 5}

\section{CIVIL SERVICES.-CLASS I}

Schedule of Sums granted, and of the sums which may be applied as appropriations in aid in addition thereto, to defray the charges of the several Civil. Services herein particularly mentioned, which will come in course of payment during the year ending on the 31st day of March 1913; viz.:-

\begin{tabular}{|c|c|c|}
\hline & \multicolumn{2}{|c|}{ Sums not exceeding } \\
\hline & Supply Grants. & $\begin{array}{l}\text { Appropriations } \\
\text { in Aid. }\end{array}$ \\
\hline $\begin{array}{l}\text { No. For expenditure in respect of royal } \\
\text { palaces, including a grant in aid . } \\
\text { 2. For expenditure in respect of Osborne . } \\
\text { 3. For the royal parks and pleasure gar- } \\
\text { dens . } \\
\text { 4. For expenditure in respect of the Houses } \\
\text { of Parliament buildings } \\
\text { 5. For expenditure in respect of miscella- } \\
\text { neous legal buildings, Great Britain } \\
\text { 6. For expenditure in respect of Art and } \\
\text { Science buildings, Great Britain (in- } \\
\text { cluding a supplementary sum of } \\
\text { 38,350l.) } . \\
\text { 7. For expenditure in respect of diplomatic } \\
\text { and consular buildings, and for the } \\
\text { maintenance of certain cemeteries } \\
\text { abroad (including a supplementary } \\
\text { sum of } 20,000 l \text {.) } \\
\text { 8. For the Customs and Excise, Inland } \\
\text { Revenue, Post Office and Telegraph } \\
\text { buildings in Great Britain, and certain } \\
\text { Post Offices abroad } \text {. } \\
\text { 9. For Labour Exchange and Insurance } \\
\text { buildings, Great Britain (including a } \\
\text { supplementary sum of } 135,000 l \text {.) } \\
\text { public buildings in Great Britain not } \\
\text { provided for on other votes . }\end{array}$ & $\begin{array}{c}£ \\
71,300 \\
13,000 \\
125,700 \\
50,800 \\
79,200\end{array}$ & $\begin{array}{c}£ \\
1,087 \\
2,400 \\
11,470 \\
400 \\
600\end{array}$ \\
\hline Carried forward & $2,390,050$ & 37,443 \\
\hline
\end{tabular}


No.

11. For the survey of the United Kingdom, and for minor services connected therewith

12. For maintaining certain harbours under the Board of Trade and for grants in aid of harbours

13. For constructing a new harbour of refuge at Peterhead

14. For rates and contributions in lieu of rates, \&c., in respect of Government property, and for rates on houses occupied by Representatives of Foreign Powers, and for salaries and expenses of the Rating of Government property department, and for a contribution towards the expenses of the London Fire Brigade . . . . .

15. For the erection, repairs, and maintenance of public buildings in Ireland, for the maintenance of certain parks and public works, and for the maintenance of drainage works on the River Shannon

16. For payments under the Tramways and Public Companies (Ireland) Act, 1883, \&c., the Railways (Ireland) Act, 1896, and the Marine Works (Ireland) Act, 1902

Total Civil Services, Class I .

\begin{tabular}{|c|c|}
\hline \multicolumn{2}{|c|}{ Sums not exceeling } \\
\hline Supply Grants. & $\begin{array}{l}\text { Appropriations } \\
\text { in Aid. }\end{array}$ \\
\hline $\mathfrak{f}$ & 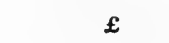 \\
\hline $2,390,050$ & 37,443 \\
\hline 214,589 & 43,475 \\
\hline 75,065 & 2,600 \\
\hline 32,000 & . \\
\hline 798,000 & 33,785 \\
\hline 273,366 & 7,960 \\
\hline 48,360 & . \\
\hline $3,831,430$ & 125,263 \\
\hline
\end{tabular}




\section{SCHEDULE (B.)-PART 6}

\section{CIVIL SERVICES.-CLASS II}

Schedule of Sums granted, and of the sums which may be applied as appropriations in aid in addition thereto, to defray the charges of the several Crvil Services herein particularly mentioned, which will come in course of payment during the year ending on the 31st day of March 1913; viz.:-

No. For the salaries and expenses of the offices
of the House of Lords.
2. For the salaries and expenses of the
House of Commons .
3. For the salaries and other expenses of
the department of His Majesty's
Treasury and subordinate depart-
ments, including expenses in respect
of advances under the Light Rail-
ways Act, 1896

4. For the salaries and expenses of the office of His Majesty's Secretary of State for the Home Department and subordinate offices .

5. For the salaries and expenses of the department of His Majesty's Secretary of State for Foreign Affairs .

6. For the salaries and expenses of the department of His Majesty's Secretary of State for the Colonies, including a grant in aid of certain expenses connected with Emigration . . .

7. For the salaries and expenses of the department of His Majesty's most Honourable Privy Council .

8. For the salaries and expenses of the office of the Committee of Privy Council for Trade, and subordinate departments (including a supplementary sum of 3750l.)

\begin{tabular}{|c|c|}
\hline \multicolumn{2}{|c|}{ Sums not exceeding. } \\
\hline Supply Grants. & $\begin{array}{l}\text { Approprititions } \\
\text { in Aid. }\end{array}$ \\
\hline$£$ & $£$ \\
\hline 28,741 & 15,000 \\
\hline 302,850 & 16,000 \\
\hline 114,371 & 4,344 \\
\hline 258,007 & 13,500 \\
\hline 68,420 & 775 \\
\hline 60,075 & \\
\hline 10,646 & 1,800 \\
\hline 365,612 & 26,446 \\
\hline $1,208,722$ & 77,865 \\
\hline
\end{tabular}


No.

9. For the salaries and expenses of certain services transferred from the Mercantile Marine Fund and other services connected with the Mcrcantile Marine (including Merchant Seamen's Fund Pensions) . . . . . . .

10. For meeting the deficiency of income from fees, \&c., for the requirements of the Board of Trade, under the Bankruptcy Acts, 1883 and 1890 .

11. For the salaries and expenses of the Board of Agriculture and Fisheries and of Royal Botanic Gardens, Kew, including certain grants in aid ${ }^{\star}$.

12. For the salaries and expenses of the Charity Commission for England and Wales

13. For the Salaries and Expenses of the Department of the Government Chemist

14. For the salaries and expenses of the Civil Service Commission

15. For the salaries and expenses of the department of the Comptroller and Auditor-General

16. For the salaries and expenses of the Registry of Friendly Societies

17. For the salaries and expenses of the Local Government Board

18. For the salaries and expenses of the office of the Commissioners in Lunacy in England

19. For the salaries and expenses of the Mint, including the expenses of coinage, and for the expenses of the preparation of medals, dies for postage and other stamps, and His Majesty's seals .

20. For the salaries and expenses of the $\mathrm{Na}$ tional Debt Office

Carried forward
Sums not exceeding

\begin{tabular}{c|c}
\hline Supply Grants. & $\begin{array}{c}\text { Appropriations } \\
\text { in Aid. }\end{array}$ \\
\hline $\begin{array}{c}£ \\
1,208,722\end{array}$ & $\begin{array}{c}£ \\
77,865\end{array}$
\end{tabular}

109,788

73,400

8

111,291

253,539

137,580

30,313

20,633

55,134

67,760

3,124

12,122

283,374

5,580

962

19,830

\begin{tabular}{|r|r} 
& \\
50 & 161,000 \\
12,580 & 3,177 \\
\hline $2,073,853$ & 573,979
\end{tabular}




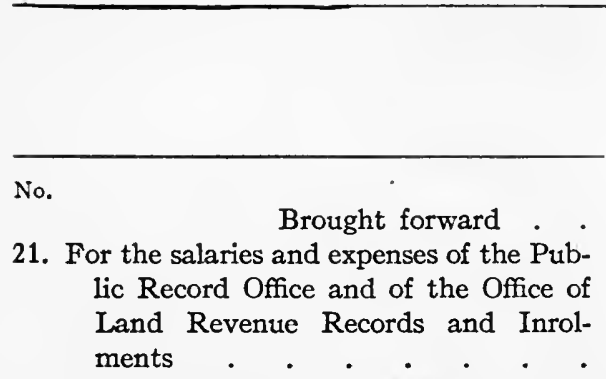

22. For the salaries and expenses of the establishment under the Public Works Loan Commissioners

23. For the salaries and expenses of the department of the Registrar-General of Births, \&c., in England

24. For stationery, printing, paper, binding, and printed books for the public service, for the salaries and expenses of the Stationery Office, and for sundry miscellaneous services, including reports of Parliamentary Debates .

25. For the salaries and expenses in the office of His Majesty's Woods, Forests, and Land Revenues

26. For the salaries and expenses of the office of the Commissioners of $\mathrm{His}$ Majesty's Works and Public Buildings.

27. For His Majesty's foreign and other secret services

28. For the salaries and expenses of the office of His Majesty's Secretary for Scotland and subordinate offices, expenses under the Inebriates Acts, 1879 to 1900, and expenses under the Private Legislation Procedure (Scotland) Act, 1899

29. For the salaries and expenses of the Board of Agriculture for Scotland

30. For the salaries and expenses of the Fishery Board for Scotland, and for grants in aid of piers or quays

31. For the salaries and expenses of the Board of Lunacy in Scotland

Carried forward

\begin{tabular}{|c|c|}
\hline \multicolumn{2}{|c|}{ Sums not exceeding } \\
\hline Supply Grants. & $\begin{array}{l}\text { Appropriations } \\
\text { in Aid. }\end{array}$ \\
\hline$\underset{2,073,853}{£}$ & $\stackrel{£}{£}$ \\
\hline 25,320 & . \\
\hline 34 & 11,800 \\
\hline 60,405 & 10,250 \\
\hline 959,751 & 140,000 \\
\hline 21,380 & $\cdots$ \\
\hline 136,750 & . \\
\hline 50,000 & $\cdots$ \\
\hline 17,126 & 2,010 \\
\hline 209,580 & 5,000 \\
\hline 24,428 & $\cdots$ \\
\hline 6,123 & 520 \\
\hline $3,584,750$ & 743,559 \\
\hline
\end{tabular}


No.

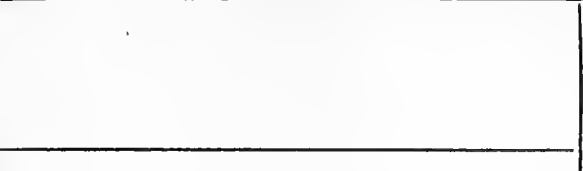

33. For the salaries and expenses of the Local Government Board for Scotland

34. For the salaries and expenses of the household of the Lord-Lieutenant of Ireland

35. For the salaries and expenses of the offices of the Chief Secretary to the Lord-Lieutenant of Ireland, in Dublin and London, and of the Inspectors of Lunatic Asylums, and expenses under the Inebriates Acts ., . .

36. For the salaries and expenses of the department of agriculture and other industries, and technical instruction for Ireland, and of the services administered by that department, including sundry grants in aid . . . .

37. For the salaries and expenses of the office of the Commissioners of Charitable Donations and Bequests for Ireland . . . . . . .

38. For the Congested Districts Board for Ireland (Grants-in-Aid) . . .

39. For the salaries and expenses of the Local Government Board in Ireland, including sundry grants in aid . .

40. For the salaries and expenses of the Public Record Office in Ireland and of the Keeper of State Papers in Dublin

41. For the salaries and expenses of the Office of Public Works in Ireland .

42. For the salaries and expenses of the department of the Registrar-General of Births, \&c., and for the expenses of collecting emigration statistics in Ireland

\section{Carried forward}

\begin{tabular}{|c|c|}
\hline \multicolumn{2}{|c|}{ Sums not exceeding } \\
\hline Supply Grants. & $\begin{array}{l}\text { Appropriations } \\
\text { in Aid. }\end{array}$ \\
\hline$\underset{3,584,750}{£}$ & $\begin{array}{c}\mathfrak{E} \\
743,559\end{array}$ \\
\hline 8,356 & 1,300 \\
\hline 20,418 & .. \\
\hline 4,552 & .. \\
\hline 27,296 & 307 \\
\hline 136,314 & 57,481 \\
\hline 2,052 & 34 \\
\hline 169,750 & .. \\
\hline 111,688 & 13,000 \\
\hline 7,446 & .. \\
\hline 46,969 & 3,000 \\
\hline 20,258 & 800 \\
\hline $4,139,849$ & 819,481 \\
\hline
\end{tabular}




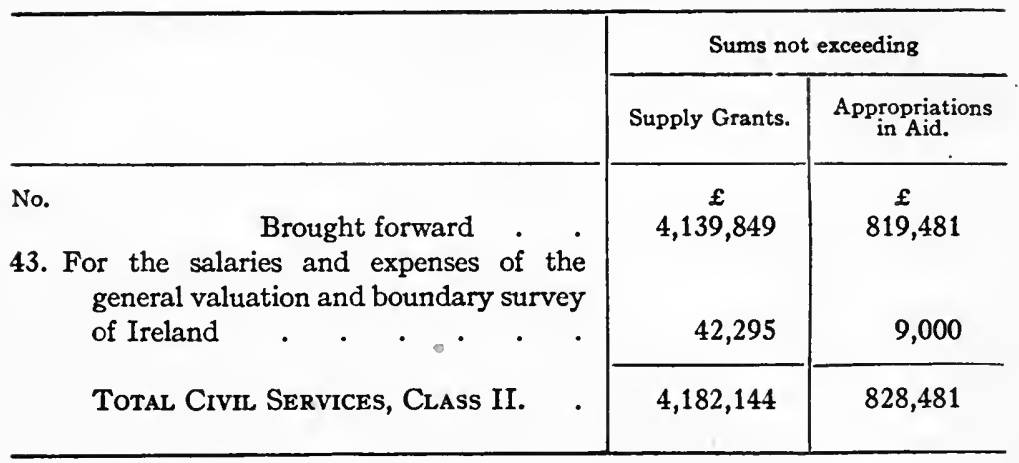




\section{SCHEDULE (B.)-PART 7}

\section{CIVIL SERVICES.-CLASS III}

SCHEDULE OF SUMs granted, and of the sums which may be applied as appropriations in aid in addition thereto, to defray the charges of the several Civil. Services herein particularly mentioned, which will come in course of payment during the year ending on the 31st day of March 1913; viz.:-

No.

1. For the salaries of the law officers department, the salaries and expenses of the department of the Solicitor for the affairs of His Majesty's Treasury and King's Proctor, and the department of Director of Public Prosecutions, for the costs of prosecutions, of other legal proceedings, and of Parliamentary Agency

2. For certain miscellaneous legal expenses, including grants in aid of the expenses of the Incorporated Law Societies of England and Ireland

3. For such of the salaries and expenses of the Supreme Court of Judicature and Court of Criminal Appeal as are not charged on the Consolidated Fund

4. For the salaries and expenses of the office of Land Registry . . . .

5. For the salaries and expenses of the office of Public Trustee

6. For the salaries and expenses connected with the County Courts . . .

Carried forward

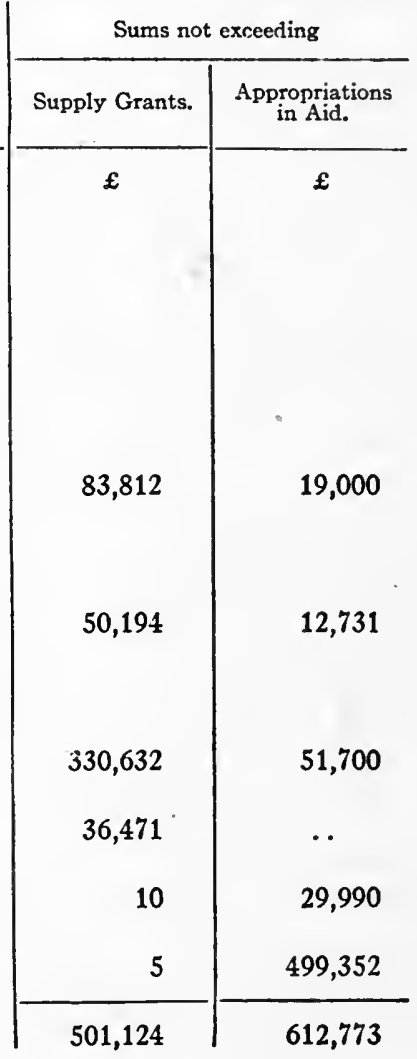




Brought forward
7. For the salaries of the Conmissioner
and Assistant Commissioners of the
Metropolitan Police, and of the Re-
ceiver for the Metropolitan Police
District, the contribution towards
the expenses of the Metropolitan
Police, and the salaries and expenses
of the Inspectors of Constabulary .
8. For the expenses of the prisons in Eng-
land, Wales, and the Colonies
9. For the salaries and expenses of the
office of the Inspector of Reforma-
tories and for the maintenance of
juvenile offenders in reformatory, in-
dustrial, and day industrial schools
and in places of detention under the
Children Act, in Great Britain .

10. For the maintenance of criminal lunatics in the Criminal Lunatic Asylums at Broadmoor and Rampton, including the furnishing and equipment of Rampton Asylum

11. For the salaries and expenses of the Lord Advocate's department and other law charges, and the salaries and expenses of the Courts of Law and Justice in Scotland

12. For the salaries and expenses of the office of the Scottish Land Court .

13. For the salaries and expenses of the offices in His Majesty's General Register House, Edinburgh .

14. For the salaries and expenses of the Prison Commissioners for Scotland, and of the prisons under their control, including the maintenance of criminal lunatics and inmates of the State inebriate reformatory, and the preparation of judicial statistics .

Carried forward

\begin{tabular}{|c|c|}
\hline \multicolumn{2}{|c|}{ Sums not exceeding } \\
\hline Supply Grants. & $\begin{array}{l}\text { Appropriations } \\
\text { in Aid. }\end{array}$ \\
\hline 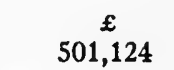 & $\begin{array}{c}£ \\
612,773\end{array}$ \\
\hline 126,998 & 77 \\
\hline 776,550 & 25,000 \\
\hline 277,474 & 25,000 \\
\hline 83,154 & 1,216 \\
\hline 87,373 & 49,300 \\
\hline 11,600 & .. \\
\hline 43,966 & $\cdots$ \\
\hline 101,776 & 5,800 \\
\hline $2,010,015$ & 719.166 \\
\hline
\end{tabular}


No.

\section{Brought forward}

15. For criminal prosecutions and other law charges in Ireland, including a Grant in relief of certain expenses payable by statute out of local rates

16. For such of the salaries and expenses of the Supreme Court of Judicature and of certain other legal departments in Ireland as are not charged on the Consolidated Fund

17. For the salaries and expenses of the office of the Irish Land Commission . .

18. For the salaries, allowances, and expenses of various county court officers, and of magistrates in Ireland, and the expenses of revision.

19. For the salaries and expenses of the Commissioner of Police, the police courts and the metropolitan police establishment of Dublin

20. For the expenses of the Royal Irish Constabulary .

21. For the expenses of the General Prisons Board in Ireland, and of the establishments under their control; the registration of habitual criminals and the maintenance of criminal lunatics confined in district lunatic asylums . .

22. For the expenses of reformatory and industrial schools in Ireland

23. For the maintenance of criminal lunatics in the Dundrum Criminal Lunatic Asylum, Ireland . . • . .

Total Crvil Services, Class III. .

\begin{tabular}{|c|c|}
\hline \multicolumn{2}{|c|}{ Sums not exceeding } \\
\hline Supply Grants. & $\begin{array}{l}\text { Appropriations } \\
\text { in Aid. }\end{array}$ \\
\hline$\stackrel{£}{£} \underset{2,010,015}{ }$ & $\stackrel{£}{719,166}$ \\
\hline 65,410 & 490 \\
\hline 113,135 & 3,900 \\
\hline 616,147 & 24,500 \\
\hline 111,145 & 5,200 \\
\hline 96,466 & 56,715 \\
\hline $1,377,389$ & 35,680 \\
\hline 112,439 & 3,500 \\
\hline 111,912 & 1,950 \\
\hline 7,477 & .. \\
\hline $4,621,535$ & 851,101 \\
\hline
\end{tabular}




\section{SCHEDULE (B.)-PART 8}

\section{CIVIL SERVICES.-ClasS IV}

SCHEdule of Sums granted, and of the sums which may be applied as appropriations in aid in addition thereto, to defray the charges of the several Civil Services herein particularly mentioned, which will come in course of payment during the year ending on the 31st day of March 1913; viz.:-

No. For the salaries and expenses of the Board
of Education, and of the various es-
tablishments connected therewith, in-
cluding sundry grants in aid (includ-
ing a supplementary sum of $15,000 l$.)
2. For the salaries and other expenses of
the British Museum, and of the Nat-
ural History Museum, including cer-
tain grants in aid ..

3. For the salaries and expenses of the National Gallery, and of the National Gallery of British Art, Millbank, including a grant in aid for the purchase of pictures

4. For the salaries and expenses of the National Portrait. Gallery, including a grant in aid for the purchase of portraits

5. For the salaries and expenses of the Wallace Collection

6. For sundry grants in aid of scientific investigation, \&c., and other grants

7. For grants in aid of the expenses of certain Universities and Colleges in Great Britain and of the expenses under the Welsh Intermediate Education Act, 1889 .

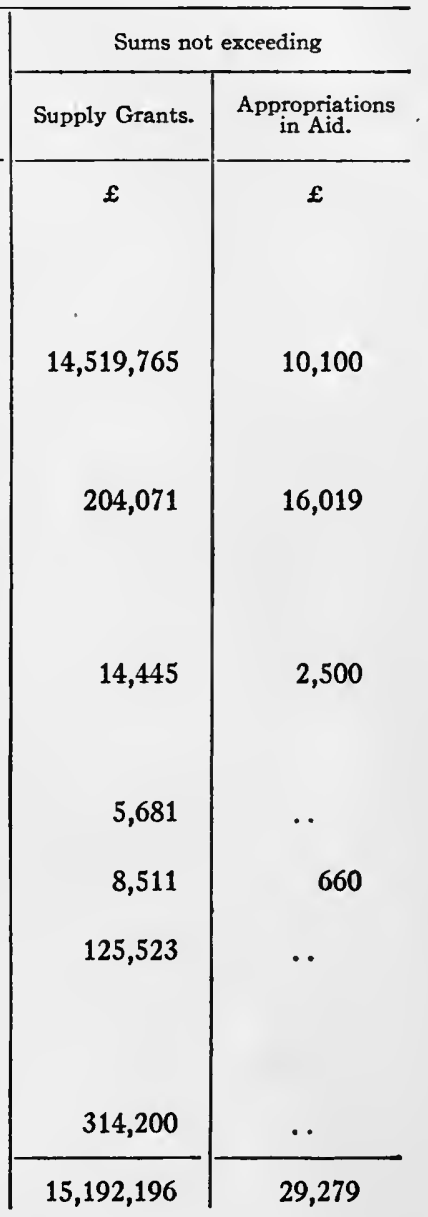

Carried forward 
No.

\section{Brought forward}

8. For public education in Scotland, and for Science and Art in Scotland, including a grant in aid . . . .

9. For the salaries and expenses of the National Gallery, the Scottish National Portrait Gallery, and the Museum of Antiquities, including certain grants in aid.

10. For the expenses of the Commissioners of National Education in Ireland, including a grant in aid of the Teachers Pension Fund, Ireland (including a supplementary sum of $10,000 l$. for expenses of scholarships tenable by pupils from primary schools in Ireland)

11. For the expenses of the Office of the Commissioners for managing certain school endowments in Ireland . .

12. For the salaries and expenses of the National Gallery of Ireland, including a grant in aid for the purchase of pictures

13. For the salaries and expenses of the Institutions of Science and Art in Dublin, and of the Geological Survey of Ireland, and Annual Grants to Schools and Classes of Science and Art and Technical Instruction, including sundry Grants in Aid, administered by the Department of Agriculture and Technical Instruction for Ireland

14. For grants under the Irish Universities Act, 1908

Total Civil Services, Class IV. .

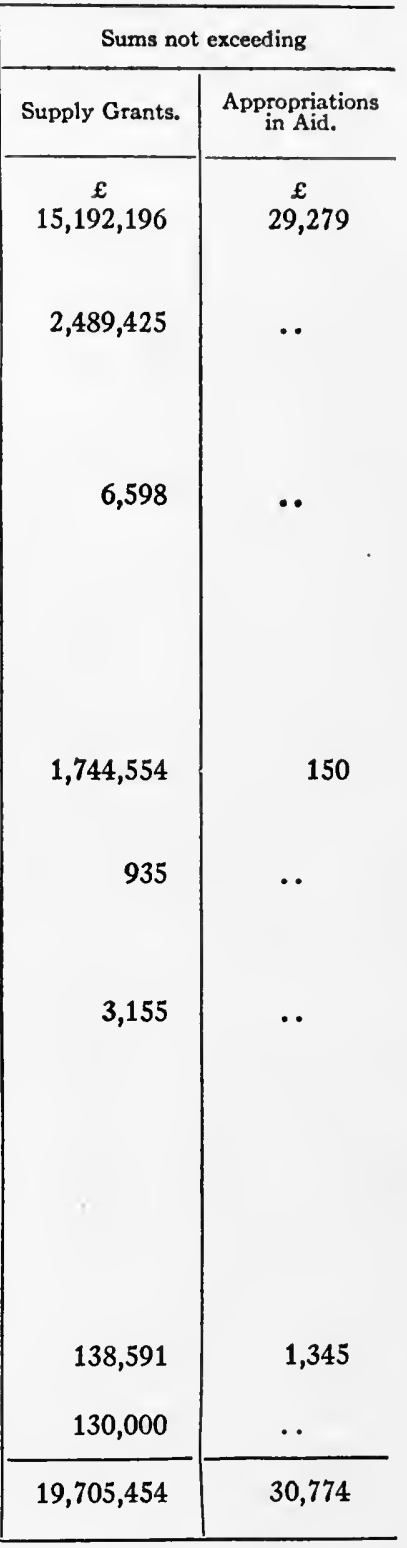




\section{APPENDIX III}

\section{SCHEDULE (B.)-PART 9}

\section{CIVIL SERVICES.-CLASS V}

Schedule of Sums granted, and of the sums which may be applied as appropriations in aid in addition thereto, to defray the charges of the several Civil Services herein particularly mentioned, which will come in course of payment during the year ending on the 31st day of March 1913; viz.:-

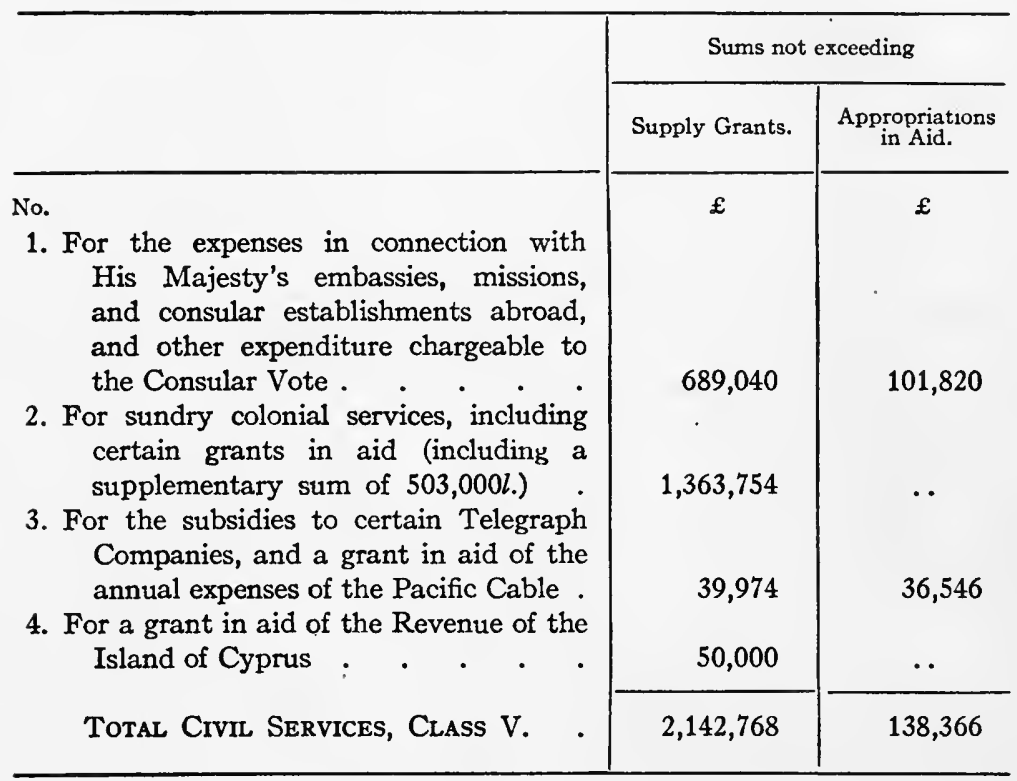




\section{SCHEDULE (B.)-PART 10}

\section{CIVIL SERVICES.-Class VI}

Schedule of Sums granted, and of the sums which may be applied as appropriations in aid in addition thereto, to defray the charges of the several Civil Services herein particularly mentioned, which will come in course of payment during the year ending on the 31st day of March 1913; viz.:-

No.

1. For superannuation, compensation, compassionate, and additional allowances, and gratuities under sundry Statutes, for compassionate allowances and gratuities awarded by the Treasury; and for the salaries of medical referees.

2. For certain miscellaneous charitable and other allowances, Great Britain

3. For hospitals and infirmaries and certain miscellaneous charitable and other allowances in Ireland, including sundry grants in aid .

4. For making good the deficiency on the Income Account of the Fund for Friendly Societies

5. For Old Age Pensions in the United Kingdom, and for certain administrative expenses in connection therewith

6. For compensation to the Registrar and Staff at Stationers' Hall on the abolition of the office of Registra

Total Civil Services, Class VI. .
Sums not exceeding

\begin{tabular}{c|c}
\hline Supply Grants. & $\begin{array}{c}\text { Appropriations } \\
\text { in Aid. }\end{array}$ \\
\hline$£$ & $£$ \\
& \\
778,253 & $\ldots$ \\
1,439 & $\ldots$ \\
& \\
16,883 & \\
& \\
14,426 & \\
$12,200,000$ & \\
\hline 3,563 & \\
\hline
\end{tabular}




\section{SCHEDULE (B.)-PART 11}

\section{CIVIL SERVICES.-CLASS VII}

SCHEDULE of Sums granted, and of the sums which may be applied as appropriations in aid in addition thereto, to defray the charges of the several CiviL SeRvices herein particularly mentioned, which will come in course of payment during the year ending on the 31st day of March 1913; viz.:-

No.

1. For the salaries and other expenses of temporary commissions, committees, and special inquiries

2. For certain miscellaneous expenses.

3. For making good certain sums written off from the assets of the Local Loans Fund

4. For the Ireland Development Grant (Grant in Aid)

5. For a grant in aid of the Government Hospitality Fund .

6. For expenditure in connection with the International Exhibition at Ghent in 1913.

7. For the repayment to the Civil Contingencies Fund of certain miscellaneous advances.

8. For contributions in aid of expenses under the Unemployed Workmen Act, 1905

Total Civil Services, Class VII.
Sums not exceeding

\begin{tabular}{|c|c|}
\hline Supply Grants. & $\begin{array}{l}\text { Appropriations } \\
\text { in Aid. }\end{array}$ \\
\hline$£$ & E \\
\hline $\begin{array}{l}33,000 \\
13,742\end{array}$ & 7,250 \\
\hline 3,418 & - \\
\hline 185,000 & .. \\
\hline 10,000 & $\cdots$ \\
\hline 30,000 & $\cdots$ \\
\hline 5,539 & $\cdots$ \\
\hline 100,000 & . \\
\hline 380,699 & 7,250 \\
\hline
\end{tabular}




\section{SCHEDULE (B.)-PART 12}

\section{CIVIL SERVICES.-ClasS VIII}

Schedule of Sums granted, and of the sums which may be applied as appropriations in aid in addition thereto, to defray the charges of the several Civil Services herein particularly mentioned, which will come in course of payment during the year ending on the 31st day of March 1913; viz.:-

No.

1. For the salaries and expenses of the National Health Insurance Joint Committee

2. For the salaries and expenses of the Insurance Commission (England), for contributions under Part I. of the National Insurance Act, 1911, and for grants in aid of expenditure incurred out of the National Health Insurance Fund in respect of benefits and expenses of administration under. that Part of that Act (including certain special grants towards the expenses of Insurance Committees) (including a supplementary sum of $42,500 l$.)

3. For the salaries and expenses of the Insurance Commission (Wales), for contributions under Part $\mathrm{I}$. of the $\mathrm{Na}$ tional Insurance Act, 1911, and for grants in aid of expenditure incurred out of the Welsh National Health Insurance Fund in respect of benefits and expenses of administration under that Part of that Act (including certain special grants towards the expenses of Insurance Committees) (including a supplementary sum of $28,350 l$.) .

Carried forward
Sums not exceeding

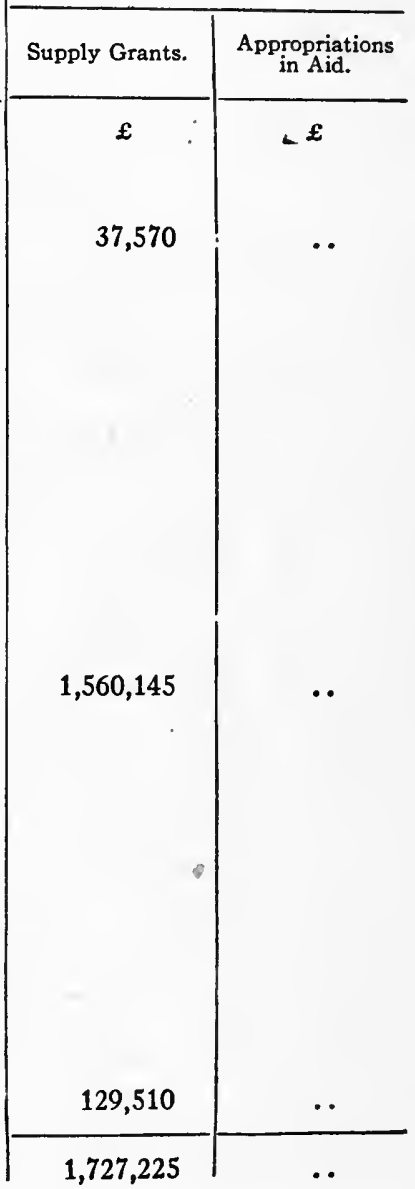




Brought forward
No.
4. For the salaries and expenses of the
Insurance Commission (Scotland), for
contributions under Part I. of the
National Insurance Act, 1911, and for
grants in aid of expenditure incurred
out of the Scottish National Health
Insurance Fund in respect of benefits
and of expenses of administration
under that Part of that Act (including
certain special grants towards the
expenses of Insurance Committees)
(including a supplementary sum of
10,000l.) . .

5. For the salaries and expenses of the Insurance Commission (Ireland), for contributions under Part I. of the National Insurance Act, 1911, and for grants in aid of expenditure incurred out of the Irish National Health Insurance Fund in respect of benefits and of expenses of administration under that Part of that Act (including certain special grants towards the expenses of Insurance Committees) (including a supplementary sum of 18,100l.)

6. For the salaries of the staff and other expenses of Labour Exchanges, including the contribution to the Unemployment Insurance Fund

7. For the salaries and expenses of the Audit Staff under Part I. of the National Insurance Act, 1911

8. For grants to Friendly Societies, \&c., in aid of the expenses of preparing schemes under section 72 of the $\mathrm{Na}$ tional Insurance Act, 1911

Total Civil Services, Class VIII .
Sums not exceeding

\begin{tabular}{|c|c}
\hline Supply Grants. & $\begin{array}{c}\text { Appropriations } \\
\text { in Aid. }\end{array}$ \\
\hline $1,727,225$ & $\ldots$ \\
& \\
& \\
& \\
& \\
& \\
& \\
& \\
& \\
& \\
\end{tabular}




\section{SCHEDULE (B.)-PART 13}

\section{REVENUE DEPARTMENTS, \&C.}

Schedule of Sums granted, and of the sums which may be applied as appropriations in aid in addition thereto, to defray the charges of the several Revenue Departments, \&c., herein particularly mentioned, which will come in course of payment during the year ending on the 31st day of March 1913; viz.:-

No.

1. For the salaries and expenses of the Customs and Excise Department

2. For the salaries and expenses of the Inland Revenue Department

3. For the salaries and expenses of the Post Office, including Telegraphs and Telephones

Total Revenue Departments .

\begin{tabular}{|c|c}
\multicolumn{2}{|c}{ Sums not exceeding } \\
\hline Supply Grants. & $\begin{array}{c}\text { Appropriations } \\
\text { in Aid. }\end{array}$ \\
\hline$£$ & $£$ \\
$2,357,900$ & 93,770 \\
$1,895,830$ & 10,000 \\
$23,808,950$ & 631,193 \\
\hline $28,062,680$ & 734,963 \\
\hline
\end{tabular}




\section{APPENDIX III}

\section{SCHEDULE (C.)}

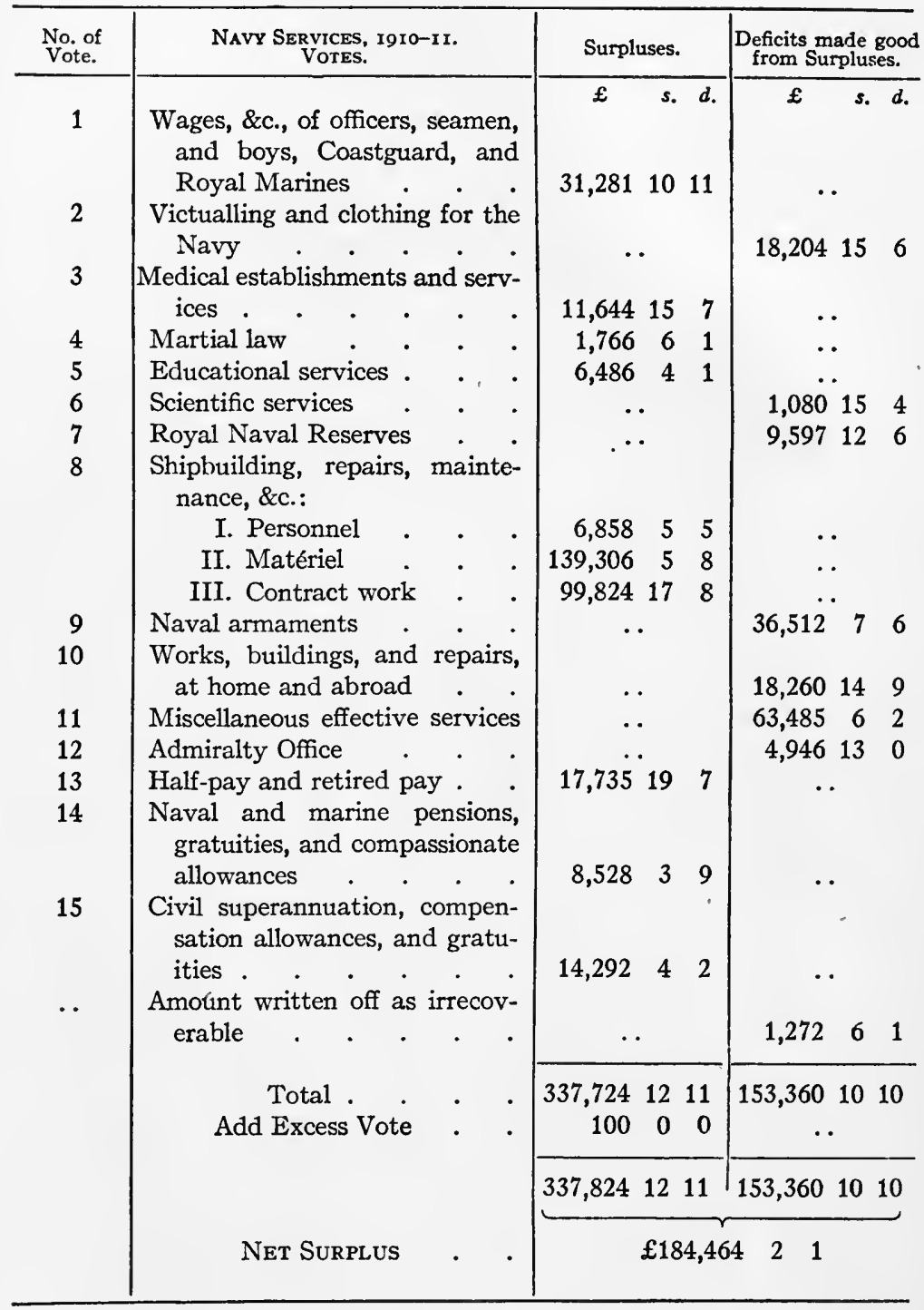


SCHEDULE (C.)

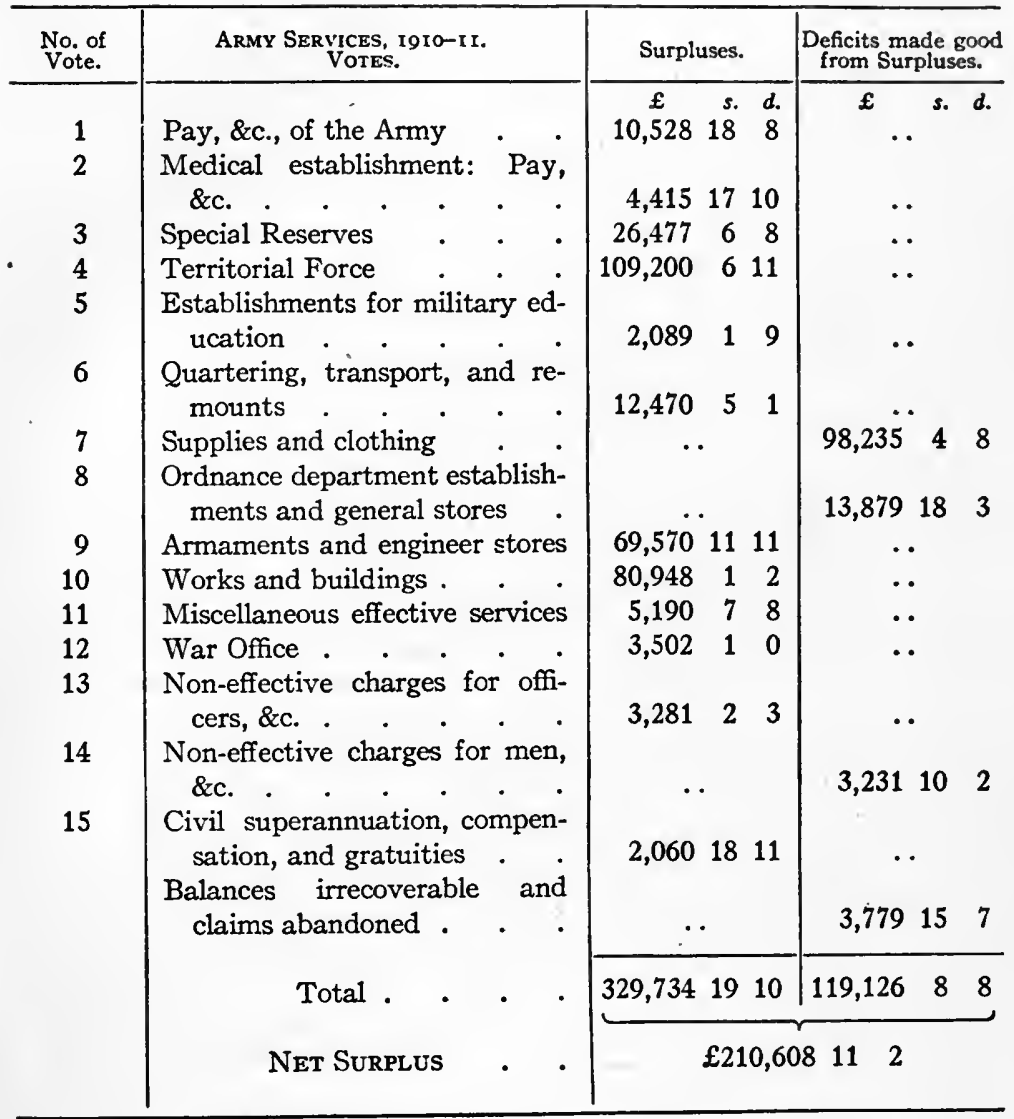




\begin{abstract}
APPENDIX IV 1
FORMS AUTHORISING AND GRANTING CREDITS AND EXCHEQUER ISSUES
\end{abstract}

\author{
FORM No. 1 \\ Treasury Requisition authorising Credits for Consolidated \\ Fund SERvices \\ Consolidated Fund Services
}

Quarter to................

By virtue of the Exchequer and Audit Departments Act, 1866 (29 \& 30 Vict. c. 39, s. 13): We authorise and require you to grant to the Lords Commissioners of His Majesty's Treasury for the time being on account of the charge of the Consolidated Fund for the Quarter ended..............., remaining unpaid at that date, Credits on the Accounts of his Majesty's Exchequer at the Bank of England and Bank of Ireland, or on the growing Balances thereof, for the following sums, viz.:-

At the Bank of England . . . $£$ At the Bank of Ireland . . . $£$

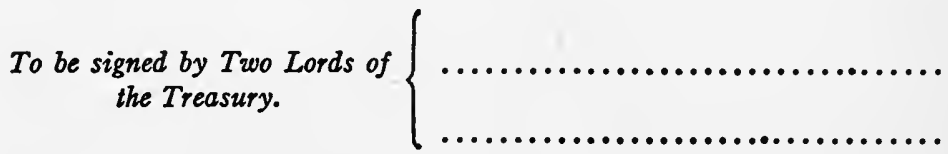
$\left.\begin{array}{c}\text { Treasury Chambers, Whitehall, } \\ \ldots \ldots \ldots \ldots 19 . \ldots\end{array}\right\}$

To the Comptroller and Auditor General.

2The forms, arranged in a different order, are to be found in Anson, Law and Customs of the Constitution, 4th ed., vol. i. pp. 316-322. 


\section{APPENDIX IV}

FORM No. 2

Grant of Credit by the Comptroller and Auditor General for Services payable out of the Consolidated Fund

Credit for Consolidated Fund Services

Quarter to...............

By virtue of the Exchequer and Audit Departments Act, 1866 (29 \& 30 Vict. c. 39, s. 13), and of a requisition from the Lords Commissioners of His Majesty's Treasury, authorising the same: I hereby grant a Credit to the Lords Commissioners of His Majesty's Treasury for the time being, on the account of His Majesty's Exchequer at the Bank of..........., or on the growing Balance thereof, to the amount of........... on account of the charge of the Consolidated Fund in Great Britain (or Ireland, as the case may be), for the Quarter ended..............., remaining unpaid at that date.

Exchequer and Audit Department, $.19 . .$.

Comptroller and Auditor General.

To the Governor and Company

of the Bank of...........

FORM NO. 3

Treasury Requisition authorising Credits for Consolidated Fund Services, payable out of the Growing Produce

\section{Consolidated Fund Services}

\section{Growing Produce}

By virtue of the Exchequer and Audit Departments Act, 1866 (29 \& 30 Vict. c. 39, s. 13): We authorise and require you to grant to the Lords Commissioners of His Majesty's Treasury for the time being, a Credit on the Account of His Majesty's Exchequer at the Bank of............, for the sum of $f \ldots \ldots \ldots \ldots$, to provide for Issues required for the following 
Services, payable out of the Growing Produce of the Consolidated Fund, in the current Quarter ending.............. . :-

\begin{tabular}{c|c|c}
\hline Sęrice. & Act. & Amount. \\
\hline & & \\
\hline
\end{tabular}

To be signed by Two Lords of the
Treasury.
Treasury Chambers, Whitehall,
............................

To the Comptroller and Auditor General.

FORM No. 4

Grant of Credit by the Comptroller and Auditor General for Services payable out of the Growing Produce of the Consolidated Fund

\section{Credit for Consolidated Fund Services}

\section{Growing Produce}

By virtue of the Exchequer and Audit Departments Act, 1866 (29 \& 30 Vict. c. 39, s. 13), and of a Requisition from the Lords Commissioners of His Majesty's Treasury, authorising the same: I hereby grant a Credit to the Lords Commissioners of His Majesty's Treasury for the time being, on the Account of His Majesty's Exchequer at the Bank of............, or on the growing Balance thereof, to the Amount of........... to provide for Services payable out of the Growing ProducE of the Consolidated Fund in Great Britain (or Ireland, as the case may be) in the current Quarter ending................

$\left.\begin{array}{c}\text { Exchequer and Audit Department, } \\ \ldots \ldots \ldots \ldots 19 . \ldots\end{array}\right\}$

To the Governor and Company of the Bank of.......... 


\section{APPENDIX IV}

ForM No. 5

Treasury Order for Issues from the Exchequer Account for Consolidated Fund Services

Consolidated Fund Services

Quarter to..................

Treasury, Whitehall, 19...

\section{Gentlemen,}

Under the authority of the Exchequer and Audit Departments Act, 1866 (29 \& 30 Vict. c. 39, s. 13), and of the Credit granted to the Lords Commissioners of His Majesty's Treasury, by the Comptroller and Auditor General on the Account of His Majesty's Exchequer at the Bank of............ under the provisions of the said Act: I am commanded by the Lords Commissioners of His Majesty's Treasury to request that you will transfer the following sums, on the .. instant, from the said Account to the "Supply Account" of [His Majesty's Paymaster General'] in your books, on account of the charge of the Consolidated Fund in [Great Britain'] for the abovementioned Quarter.

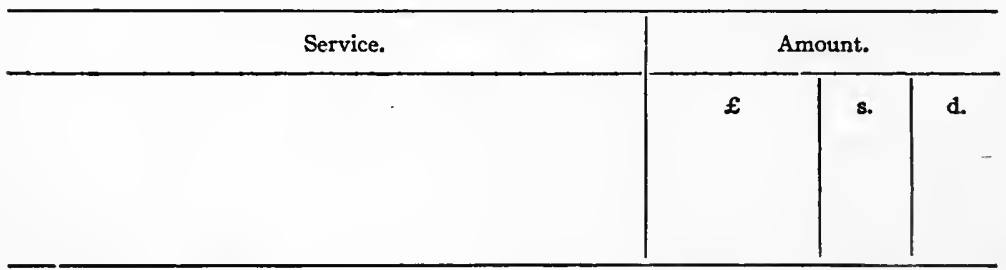

I am to request that when these sums have been transferred accordingly, you will transmit this authority to the Comptroller and Auditor General.

I am, \&c.

To be signed by one of the

Secretaries of the Treasury.

To the Governor and Company

of the Bank of..........

1 [or of such other Principal Accountants as the case may require.]

2 [or Ireland.] 


\title{
APPENDIX IV
}

\author{
FORM NO. 6 \\ Royal Order for Public Supply Services \\ (For His Majesty's Royal Sign Manual) \\ ROXAL ORDER
}

\section{SuPPLy Services}

WhEREAS the several sums mentioned in the Schedule hereunto annexed have been granted to Us (by Act, or by Resolution of the House of Commons, as the case may be) to defray the expenses of the Public Supply Services therein specified, which will come in course of payment in the year ending the 31st March 19... OUR wILl aNd Pleasure is, that you do, from time to time, authorise the Governor and Company of the Bank of England, or the Governor and Company of the Bank of Ireland, to issue or transfer from the Account of our Exchequer at the said Banks to the Accounts of the persons charged with the payment of the said Services, such sums as may be required, from time to time, for the payment of the same, not exceeding the amounts respectively stated in the said annexed Schedule.

Provided that such issues or transfers shall be made out of the Credits granted or to be granted to you, from time to time, on the Account of Our Exchequer at the said Banks, by the Comptroller and Auditor General, under the authority of the Exchequer and Audit Departments Act, 1866 (29 \& 30 Vict. c. 39, s. 15), and shall not exceed in the whole the amount of the Credits so granted out of the Ways and Means appropriated by Parliament to the Service of the said year.

Given at Our Court at.............this................day of...................

By His Majesty's Command, To be countersigned by Two
Lords of the Treasury.

To the Commissioners of Our Treasury.

SCHEDULE.

\begin{tabular}{l|lll}
\hline Supply Service for which Valued or Granted. & \multicolumn{3}{|c}{ Amount. } \\
\hline & e & s. & d. \\
& & & \\
\hline
\end{tabular}




\title{
APPENDIX IV
}

\author{
FORM No. 7 \\ Treasury Requisition authorising Credits for Supply \\ SERVICES
}

SUPPLy SERVICES

Year 19...

By virtue of the Exchequer and Audit Departments Act, 1866 (29 \& 30 Vict. c. 39, s. 15):-We authorise and require you to grant to the Lords Commissioners of His Majesty's Treasury for the time being, on account of the Ways and Means granted for the service of the year ending 31st March 19.., Credit on the Account of His Majesty's Exchequer at the Bank of England and Bank of Ireland, or on the growing Balances thereof, for the following sums; viz.:-

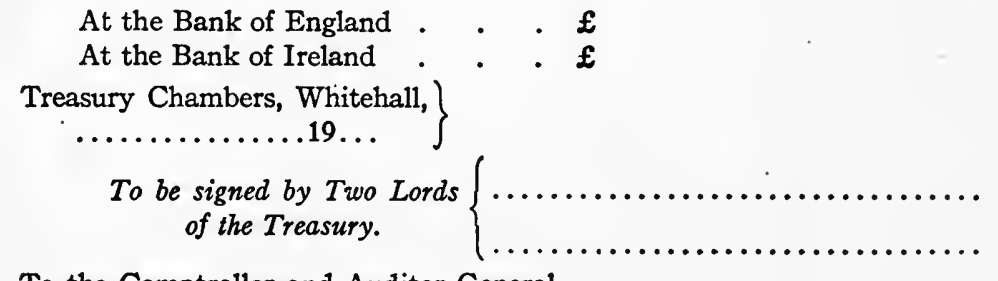

To the Comptroller and Auditor General.

FORM No. 8

Grant of Credit by the Comptroller and Auditor General for Supply SERVICES

Credit for Supply Services

\section{Year 19...}

By virtue of the Exchequer and Audit Departments Act, 1866 (29 \& 30 Vict. c. 39, s. 15), and of a Requisition from the Lords Commissioners of His Majesty's Treasury authorising the same: I hereby grant a Credit to the Lords Commissioners of His Majesty's Treasury for the time being, on the Account of His Majesty's Exchequer at the Bank of............. or on the growing Balance thereof, to the Amount of..$\ldots \ldots \ldots \ldots \ldots \ldots$. 


\section{APPENDIX IV}

on account of the Ways and Means granted for the Service of the year ending 31st March 19...

$\left.\begin{array}{c}\text { Exchequer and Audit Department, } \\ \ldots \ldots \ldots \ldots \text {............. }\end{array}\right\}$

Comptroller and Auditor General.

$\left.\begin{array}{c}\text { To the Governor and Company of } \\ \text { the Bank of............ }\end{array}\right\}$

FORM No. 9

Treasury Order for Issues from the Exchequer Account for SUPPLy Services

Supply Services

Year 19...

Treasury, Whitehall, $.19 .$.

\section{Gentlemen,}

Under the authority of the Exchequer and Audit Departments Act, 1866 (29 \& 30 Vict. c. 39, s. 15), and of the Credit granted to the Lords Commissioners of His Majesty's Treasury, by the Comptroller and Auditor General, on the Account of His Majesty's Exchequer at the Bank of........., under the provisions of the said Act: I am commanded by the Lords Commissioners of His Majesty's Treasury to request that you will transfer the following sums, on the........... instant, from the said Account to the "Supply Account" of [His Majesty's Paymaster General1] in your books, on account of the Supply Services under-mentioned:-

\begin{tabular}{l|l}
\hline Supply Services. & Amount. \\
\hline & \& s. d. \\
\hline
\end{tabular}

2 [or of such other Principal Accountants as the case may require.] 


\section{APPENDIX IV}

I am to request that when these sums shall have been transferred accordingly, you will transmit this authority to the Comptroller and Auditor General.

To be signed by one of the

I am, \&c.

Secretaries of the Treasury.

To the Governor and Company of the

Bank of ............ 



\section{INDEX}

Accounting officers, review acts of Paymaster General, 150; departmental, are not paymasters, I56; one for each vote, 156 ; dignity of office, 158 ; financial control exercised by, I59; Treasury Minute on duties of, I60; responsibility to Treasury, I6I ; personal liability of, I62; not bonded, 163

Adams, H. C., "Science of Finance," $26 n$

Appropriation Accounts, summary for civil services and revenue departments, 248-252

Appropriation acts, must be initiated by or have approval of Crown, 38; prepared only after discussion and decision on authorization of expenditures, I25; English and American practice, 125; two general bills prepared and enacted, I 28

Appropriation heads, facts of importance, $8 \mathrm{I}$; subheads, 82-90

Appropriations, forms of acts of, I8; itemization of, 27-28; historical development of, 2830 ; powers of Parliament over, 37-39; distinction between permanent and annual, 40-4I; for Consolidated Fund Services, 42-43; continuing criticism of, $43-45$; made only in pursuance of formal estimates, 47-48; heads under which made, 74-8I ; significance of transfers permitted, 82-83; subheads classified by objects,
87 ; subheads, illustration of, 88-90; supporting details, 9092 ; American system of reimbursable, II2; control over by House of Commons, I29; by "Votes," I29; expenditures of, not mandatory, I65

Appropriations in aid, 35; theory of, IOO-IO3; a "token," IOI-IO2; arguments for, 103-106; first applied to Army and Navy, I04; gradually adopted for civil services, I05; policy of, frequently reviewed and confirmed, 105; Treasury Minute on, I06; not consistent with budgetary principles, 107; does not promote efficiency, I08; fundamental objection to, 108I09; departures from, I09; $\mathrm{Mr}$. Cox's criticism of, IIO-III; contrast with American system of reimbursable appropriations, I I2

Army, estimates, character and number of votes, 74-75

Bank of England, custodian of funds, 37

Bank of Ireland, custodian of funds, 37

Bowles, Thomas Gibson, origin of Exchequer, 36-37; attack on system of transfers, 83-84; criticism of system of appropriations in aid, II $4 n$; functions of Standing Committee on Public Accounts, 228

Budget, revenue as part. of, 2; 
collection and records, 2 ; standards, 2-8; audit and reports, 3 ; custody, 3 ; expenditures, 3 ; preparation of estimates, 3-4; nature of, 5-8; definition, 7-8; Economy and Efficiency Commission recommendations, 8IO; problem of control, IO-23; preparation of estimates, I3-I4; review of estimates, I4; hearings, I5; procedure, I6-I7; itemization, extent of, I8; administrative control through Finance Department, 19; difference between English and American systems, 19-20; estimates only part of, 72 ; meaning of, 255-256; summary statement by Chancellor of Exchequer, 256-264; budget speech, 265 ; deals primarily with revenues as variable factor, 266267 ; consolidation of proposals, 268; principles applicable to American financial administration, 269-270; principles applied in British system, 27I-275; contrast of English and American practice in financial administration, $276-280$

Bureau of Municipal Research, reports on budget procedure, 270-272

Chalmers, Sir Robert, testimony on Treasury control over departmental estimates, 62 ; duties of permanent Secretary of Treasury, I73-I74; duties of estimate clerks, I74

Civil list, evolution of, $3^{\text {I-33 }}$; definition of, $34 n$

Civil services, 73-74; estimates, character and number of votes, 76-8I

Cleveland, Frederick A., Editor's note, v-vii; contributions to budget discussion, 270-272

Commission on Economy and Efficiency, President Taft's, work of, $270-272$

Comptroller and Auditor General, functions of, I44-I45; status of, 216-218; no power of disallowance, 222 ; no interference with executive responsibility, 222223; duty to secure economy, 224-226; relation to Standing Committee on Public Accounts, 229

Comptroller of United States Treasury, power to prescribe manner of keeping and rendering accounts, 20

Consolidated Fund, importance of, 34-35; (No. I) Bill (I9I2), text of, 3I4-3I5; (Appropriation) Act (I9I2), text of, 3I6347

Consolidated Fund Services, characteristics of, $4 \mathrm{I}$; items of, 42 Construction of public buildings, progress reports on, 55

Cox, Harold, criticism of continuing appropriations, 43-45; objections to system of appropriations in aid, IIO-III

"Credits" to Treasury, I46

Economy and Efficiency, recommendations of Taft Commission on, 8-10

Estimate clerks, duties of, 174

Estimates, recommendations of Taft Commission on, 9; preparation of, I3-I4; legislative review, I4; central executive review, I4; review by department heads, I4; distinguished from appropriations, I4; originate with executive, 47-48; act of Ministry, 48; Treasury 
agent of Ministry in preparation and submission of, 49 ; reviewed by Treasury, 49-50; Army and Navy, procedure for, 50-5I; forms of, prescribed by Treasury, 5I; preparation and submission, 52 ; Treasury circular, 52-59; regulations to be observed in preparation, 52-59; date of rendering, 53 ; explanation of, 54 ; form of, explanation of increases and decreases, 59-6o; Treasury control, 6r ; summation of prior decisions, 62 ; supplementary data, $62-63$; personnel, list of, included in, 63 ; incidental expenses, details of, 63 ; comparative data prepared by Treasury, 63-64; data filled in by department, 64; preparation of, within departments, 65-67; responsibility for departmental review placed on permanent accounting officer, 66-67; Treasury examination of, 67-69; transmission of, to House of Commons, 69-70; supplementary, 70; character and form, 73-99; classification of, 73-74; general summaries, how assembled, 93-100; details, how presented, 93 ; explanatory memorandum, 94; abstracts of, 95; comparison with expenditures, 95 ; criticism of character and form, 99; procedure in Parliament, II5-I43; Select Committee on (I9I2), 134-140; recommendations of Select Committee on National Expenditure (I902), I35; comments of E. Hilton Young, 142 ; approval of, does not sanction expenditure, 167

Excess votes, Civil Contingency Fund, 128; investigation by
Public Accounts Committee, 128

Exchequer, origin of, 36-37; issue of money to principal accountants, 147

Exchequer and Audit Departments Act (1866), 146; text of, 283-307; Treasury Minute on (1867), 307-313

Executive, lack of responsibility in U. S., 20; responsibility for expenditure of money, 38 ; for organization and personnel, 169 Expenditures, control over, by Treasury, 20-22; control over, by department heads, 20-21; made only in pursuance of appropriations by Parliament, 2628; Parliamentary control over, 27 ; limitation of, under Charles II, 29-30; for royal household, 32-33; comparison of, in estimates, $62-63$; report of Select Committee on National Expenditure, quoted, 65-69; classified by services, 73 ; statement for series of years, 98 ; distinction between authorization and appropriation of funds, 124 ; procedure with respect to authorization, I24; Select Committee on National Expenditure, established (I902), r34-I35; appropriations not mandatory, 165; Treasury must authorize, 166; comparative summary of, 252-254

"Finance accounts," two reports to Parliament, 235; annual report since 1802,236 ; two basic tables, promptly rendered, summarize financial transactions, 237; summary of, 238-241 ; cash assets only listed, 242; debt statement, 243 ; do not summar- 
ize operations for series of years, 246; appropriation accounts, analysis in summary, 247 ; no report of audited receipts and expenditures, 253254

Financial Secretary, staff of, I73 Financial system, contrast with American practice, 39-40

Fiscal year, United States, 24; England, 24

Goodnow, Frank J., Foreword, ix; financial administration, 27 In

Hamilton, Sir Edward, power of transfer between appropriations desirable, 86; defense of appropriations in aid, II $4 n$

Higgs, Henry, "The Financial System of the United Kingdom," 34; financial control of House of Commons, I $3 \mathrm{I}$; forms used by Treasury, I $48 n$

Home Office, subheads of appropriation, 88-90 ; supporting details, 90-92

House of Commons, exclusive financial power of, II5; Parliament Act of I9II, II6; standing orders on financial business, II9-I24; control exercised over appropriations, I29; control limited to review, criticism, approval or disapproval, I30; facilities for discussion and criticism of finances, $\mathrm{I} 3 \mathrm{I}$

House of Lords, divested of powers over money bills, II 6

Itemization of appropriations, extent of, $27-28$

Lowell, A. Lawrence, Introduction, xi-xii ; financial discussion in House of Commons, $13 I^{-}$ I32; evolution of Treasury, I72; Financial Secretary, staff of, I73; English financial administration, 27 I $n$

Maitland, F. W., sources of public income, 28; tax levies, 29; grants to crown, 30

National Debt, statement, 243. See "Finance Accounts"

Navy, estimates, character and number of votes, $75-76$

Office of Works and Public Buildings, furnishes supplies for offices and buildings, 194; evolution of supply work, 194-I95; powers to control expenditures, rg6. See Public Works

Parliament, origin of control over expenditures, 28-30; powers over appropriations, $37-38$

Paymaster General, chief, pays all obligations, I49; centralized office, 150

Personnel, list of, in estimates, 63

Public accounts, theory of, 24-26; accrual basis, 25-26; advantages and disadvantages of cash basis, 25-26; audit of, 209; early methods of audit, 210; development of present system of control, 2II

Public Accounts Committee, extra receipts report, I03-I04; House of Commons establishes by standing order (I866), 216; Exchequer and Audit Departments Act (1866), 216; methods of keeping and rendering accounts prescribed by Treasury, 218; procedure audit of, 
219; reports of, rendered to Comptroller and Auditor General, 220-22I ; audit continuous, $22 \mathrm{I}$; instrument of control in hands of Opposition, 228; Comptroller and Auditor General, staff agent of, 229; reviews Treasury administration, 230; value of, 23I; reports findings to Treasury, 232; relies on publicity, 233; does not interfere with responsibility of Treasury, 234. See "Finance Accounts"

Public documents, printing and distribution of, 207

Public funds, custody of, 23

Public Moneys, Committee on (1856-57), report on consolidation of Paymaster offices, I50$\mathrm{I}_{5} \mathrm{I}$; recommendations on financial control, 213-215

Public works, distinction between construction of, for public use and for government, 183-184; executive responsibility for, avoids "pork barrel" methods, I85; centralized control, I86; functions of Office of "Works and Public Buildings, 186-187; voting funds for, 188 ; longterm plans for, 189; policy of contracts, I9I ; rentals and repairs of buildings, I92. See Office of Works and Public Buildings

\section{Revenue services, 73-74}

Stationery Office, stationery and printing, supply service, I98; estimates for all departments, 199; estimates with supporting details, I99-20I; allotment of appropriations by, 202; Treasury Minutes (1912) on expen- diture for, 202-203; procedure in purchase and issue of supplies, 204-206; control of expenditures, 208

Stourm, René, "Le Budget," $26 n$ Supply Services, 4I-42; characteristics of, $4 \mathrm{I}-45$

Taft, William H., President's Commission on Economy and Efficiency, 270; American financial methods, 27 I $n$

Transfers of appropriations, reasons for, 82-83; defects in procedure, 84 ; procedure and advantages of, $85-86$; safeguards against abuses, 86

Treasury, submits estimates, 4950; estimates circular, 52-59; control over estimates exercised before submission, $6 \mathrm{I}$; power to review any item of expenditure, 64-65; Estimate Clerk, duties of, 67-69; examination of estimates, 67-69; review of estimates by Financial Secretary, 69; credits, 146 ; funds, 146 ; sanctions expenditures, 167 ; independent control of, over expending departments, I68; exercises control as agent of chief executive, I69; control over salaries, I70; control over expenditures for supplies, I7I ; organization of, for financial control, $17 \mathrm{I}-172$; Chancellor of Exchequer responsible head, 172 ; permanent Secretary of, I73-174; committees of investigation, $175-177$; as organ of administrative control, I78; continuous supervision of, I79; not a public service department, 180 ; responsible for general efficiency of governmental business, I8I- 


\section{INDEX}

182; prescribes methods of keeping and rendering public accounts, 218 ; forms, authorizing and granting credits and Exchequer issues, 348-355

Treasury System, official description of, by Chancellor of Exchequer (I885), I 52-I55

United States, lack of central executive control, 20

Virement, power of, 82

"Votes," distinguished from subheads, 82 ; character and number of, $74-8 \mathrm{I}$; subheads, illustration of, 88-90; subheads, supporting details of, $90-92$
Votes of credit, to meet emergencies, 128

Votes on Account, 55; embodied in Consolidated Fund (No. I) Act, 126; restricted to services authorized, I26

Welby, Lord, memorandum on audit, 2II-2I3; memorandum on financial accounts, 236

Willoughby, W. F., budget control, 2In

Young, E. Hilton, System of National Finance, viin; views on Select Committee on Estimates, I42-I 43 



I

\section{THE LIBRARY}

UNIVERSITY OF CALIFORNIA

Santa Barbara

THIS BOOK IS DUE ON THE LAST DATE STAMPED BELOW. 


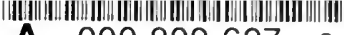

A $000809627 \quad 3$

I DEAL

OOKSTORE 


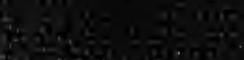

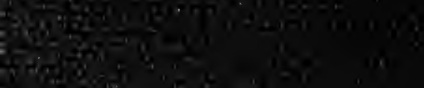

